\title{
HYDROTHERMAL CONVERSION OF BIOMASS
}


Promotion committee:

Prof.dr. W.J. Briels

Prof.dr.ir. W.P.M. van Swaaij

Dr. S.R.A.Kersten

Dr. Frans Goudriaan

Prof.dr.ir. M.J. Groeneveld

Prof.dr.ir. A. Nijmeijer

Prof.dr.ir. W. Prins

Dr.ir. D.W.F. Brilman

Prof.dr. M. Radovanović
Chairman University of Twente Promoter University of Twente Assistent promoter University of Twente Biofuel B.V.

University of Twente University of Twente University of Ghent University of Twente University of Belgrade, Serbia

The research reported in this thesis was executed under:

1. a grant of the Netherlands Organization for Scientific Research-Chemical Sciences (NWO-CW) in the framework of the research program "Towards Sustainable Technologies", subproject BIOCON with the financial contributions from Shell Global Solutions International B.V. and the Dutch Ministries of Economic Affairs (EZ/SenterNovem) and Environmental Affairs (VROM).

2. a grant of the European Commission in the 6th Framework Program: BIOCOUP project (Contract Number: 518312).

Cover design: Ti Computers

Publisher: Printpartners Ipskamp Drukkers B.V., P.O.Box 333, 7500 AH Enschede

(C) 2009, Dragan Knežević, Enschede, The Netherlands.

No part of this work may be reproduced in any form by print, photocopy or any other means without written permission from the author.

ISBN 978-90-365-2871-9

DOI 10.3990/1/9789036528719 


\section{HYDROTHERMAL CONVERSION OF BIOMASS}

\section{PROEFSCHRIFT}

ter verkrijging van

de graad van doctor aan de Universiteit Twente, op gezag van de rector magnificus,

prof.dr. H. Brinksma

volgens besluit van het College voor Promoties

in het openbaar te verdedigen

op donderdag 3 september 2009 om 16.45 uur

door

\section{Dragan Knežević}

geboren op 29.10.1975

te Belgrado, Servië 
Dit proefschrift is goedgekeurd door de promotor:

Prof.dr.ir. W.P.M. van Swaaij

en de co-promotor:

Dr. S.R.A. Kersten 
To my family 


\section{CONTENTS}

Summary.

$\begin{array}{ll}\text { Samenvatting. } & 3\end{array}$

$\begin{array}{ll}\text { Abstrakt. } & 5\end{array}$

$\begin{array}{lll}\text { Chapter } 1 & \text { Introduction. } & 7\end{array}$

Chapter 2 High-Throughput Screening Technique for Conversion in Hot Compressed Water: Quantification and Characterization of Liquid and Solid Products.

Chapter 3 Hydrothermal Conversion of Biomass - Part I:

Glucose Conversion in Hot Compressed Water.

Chapter 4 Hydrothermal Conversion of Biomass - Part II:

Conversion of Wood, Pyrolysis Oil and Glucose in Hot

Compressed Water.

Chapter 5 Development of a Continuous Bench Scale Plant.

Chapter 6 Conclusions, Outlook and Recommendations.

Acknowledgements.

Curriculum Vitae.

List of Publications. 



\section{Summary}

Shifting towards a sustainable and renewable society is an imperative in the modern world. Energy production will play a key role in this process and several routes will be needed. Biomass is one of the options for renewable and sustainable energy. Different routes from biomass to improved energy carriers are shortly reviewed in this thesis. One of these routes is hydrothermal conversion of biomass (HTC). In this process, hot compressed water (subcritical water) is used as the reaction medium. Therefore this technique is suitable for conversion of wet biomass/ waste streams, either for their disposal, or for production of high-value products. The evaporation of water and its high energy consumption can be avoided in this process by operating at high pressures. However, temperatures and pressures are still lower than in the supercritical water gasification process.

This thesis deals mainly with HTC process aiming at production of transportation fuel intermediates. For this study, a new experimental technique using quartz capillary batch reactors has been developed, allowing determination of the yields of gas, liquid and solid products, and their subsequent analysis.

The study includes important HTC features such as, undesired char formation, deoxygenation, and mechanism and kinetics of formation of different lumped product classes.

First, the newly developed technique is presented. The experimental methods and product separation and handling procedures are discussed in detail and validation of the technique has been presented including statistical considerations.

This technique is subsequently used for HTC of glucose. Special attention is given to the kinetics of the initial glucose decomposition. Tests using the capillaries have also been performed with primary decomposition products reported for HTC and this helped to pinpoint the origins of gas and water formation in the early stages of the process. Formation of char from these primary decomposition products is evaluated, showing that all primary products are susceptible to charring, although to a different extent. Complete mass and elemental balances are obtained for HTC of glucose solutions for two different temperatures, $300{ }^{\circ} \mathrm{C}$ and $350{ }^{\circ} \mathrm{C}$, various residence times, from $10 \mathrm{~s}$ to 10 days, and different feedstock concentrations. The data significantly complements the literature findings on the reaction mechanism of HTC of glucose. The observed trends in the product formation rates and yields are used to obtain an engineering reaction model for decomposition of glucose.

Then the attention is directed to HTC of more complex feedstocks, wood and pyrolysis oil, for which complete mass and elemental balances are obtained for $350{ }^{\circ} \mathrm{C}$ at different residence times and feedstock concentrations. The comparison of the results of all feedstocks used reveals several similarities in product yields and the rates of their 
formation, as well as, in product composition. For glucose, wood and pyrolysis oil, water is produced almost exclusively in the first 5 minutes of the process, while gas and char yields are found to increase steadily over time, at the cost of the desired oil yield. Also yields of gas and water were found to be independent of the feedstock concentration. Due to their very similar elemental composition it is concluded that oil and char, called respectively water-solvent soluble (WSS) and water-solvent insoluble (WSIS) products, are essentially the same, with the difference between them being only their molecular weight.

It was also observed that the composition of the oil remains almost constant at longer residence times.

Tests in the presence of a typical catalyst for gasification at hydrothermal conditions are also described, but hardly any improvement of the oil yield and composition is found in these tests.

Two distinct mechanisms of char formation are identified and two mechanisms of deoxygenation (dehydration and decarboxylation) are discussed. The findings have been used to extend the engineering model for glucose conversion to the HTC of complex feedstocks. Additionally, several catalysts have been screened on their potential of increasing the decarboxylation yield from pyrolysis oil; and phase behavior of the HTC reaction products has been visually observed in special tests.

Finally, a bench scale continuous reactor setup for HTC is proposed. The setup is based on a wish list compiled to allow safe, simple, efficient and cheap experimentation. Several features of the setup have been tested separately in cold-flow, such as, feeding of biomass water slurries with a piston autoclave and a lifting fluidized bed, heat transfer, fluid bed operation and state of mixing of liquid and solid phases in continuous operations. Some observations during attempted experiments in hot-flow are also discussed. 


\section{Samenvatting}

De transitie naar een hernieuwbare en duurzame samenleving is een noodzaak in de moderne wereld. De productie van energie zal een belangrijke rol spelen in dit proces en verschillende (gezamenlijke) routes zullen nodig zijn. Biomassa is een van de opties voor hernieuwbare en duurzame energie. Verschillende conversieroutes om uit biomassa betere en efficiëntere energiedragers te maken, zijn in het kort beschreven in dit proefschrift. Een van deze routes is hydrothermale conversie van biomassa (HTC). In dit proces wordt gebruik gemaakt van heet water onder druk (subkritisch water) als reactiemiddel. Deze techniek is dus geschikt voor de conversie van natte biomassa/afvalstromen, hetzij als afvalverwerkingtechnologie, of voor conversie naar hoogwaardige producten. Het hoge energieverbruik is noodzakelijk voor de verdamping van het water uit de natte biomassa. In het HTC proces kan dit energie verbruik voor het water verdampen worden vermeden door te werken onder hoge druk. De temperaturen en drukken zijn echter wel lager dan in het superkritische water vergassing proces.

Het hoofdonderwerp van dit proefschrift is het HTC-proces gericht op de productie van tussenproducten (olie), die vervolgens naar hoogwaardige transportbrandstoffen kunnen worden opgewaardeerd. Tijdens deze studie is een nieuwe experimentele methode ontwikkeld, waarin gebruik wordt gemaakt van kwartsglazen capillairen als batch reactoren. Met deze methode kunnen, na afloop van het experiment, zowel de opbrengsten van de gassen, vloeibare en vaste producten worden bepaald en vervolgens kunnen de producten worden geanalyseerd.

Dit proefschrift is gewijd aan het bestuderen van de belangrijke eigenschappen van het HTC-proces, zoals ongewenste char (koolachtig materiaal) vorming, verwijdering van zuurstof uit het hoofdproduct en reactie mechanisme en reactie kinetiek van de verschillende complexe reacties die plaatsvinden.

Als eerste wordt de ontwikkelde methode gepresenteerd. De experimentele procedures en verwerking en behandeling van reactie producten zijn in detail beschreven en de methode is statistisch gevalideerd.

De techniek wordt vervolgens gebruikt voor de studie naar de HTC reacties van glucose. Speciale aandacht wordt besteed aan de kinetiek van de initiële afbraak van glucose. Soortgelijke proeven zijn uitgevoerd met stoffen die in de literatuur als primaire afbraakproducten van glucose zijn geïdentificeerd. Dit heeft bijgedragen aan het lokaliseren van de oorsprong van gas en water, die vroeg in het proces ontstaan. Vorming van char uit deze primaire afbraakproducten van glucose is ook bestudeerd en het blijkt dat alle primaire producten in verschillende mate gevoelig zijn voor char vorming. Volledige massa en energiebalansen zijn verkregen voor HTC van glucose oplossingen bij twee verschillende temperaturen, $300{ }^{\circ} \mathrm{C}$ en $350{ }^{\circ} \mathrm{C}$, verschillende verblijftijden, van $10 \mathrm{~s}$ tot 10 dagen, en 
gevarieerde glucose concentraties. Deze data is een belangrijke aanvulling op de bevindingen beschreven in de literatuur. De experimentele data is dan gebruikt voor het opstellen van een ingenieurs reactie model van glucose afbraak onder HTC proces condities.

Vervolgens is aandacht besteedt aan de HTC van complexere grondstoffen, zoals hout en pyrolyse olie. Goed sluitende massa- en energiebalansen worden verkregen voor de experimenten bij $350{ }^{\circ} \mathrm{C}$ en verschillende verblijftijden en grondstofconcentraties. Wanneer de resultaten van de experimenten met verschillende grondstoffen worden vergeleken, zijn er overeenkomsten zichtbaar met betrekking tot de productopbrengsten, vormingssnelheden en samenstellingen. Voor zowel glucose als hout- en pyrolyse olie wordt reactiewater uitsluitend geproduceerd tijdens de eerste 5 minuten van het proces. Gas en char worden wel tijdens het gehele experiment gevormd. Dit gaat echter ten koste van de olieopbrengst. De gas- en wateropbrengsten bleken onafhankelijk van de grondstofconcentratie te zijn. Door de vergelijkbare elementaire samenstelling van olie (oplosbaar in water en polair oplosmiddel - WSS) en char (onoplosbaar in water en polair oplosmiddel - WSIS) zijn deze producten in essentie hetzelfde, met als enige verschil hun moleculairgewicht. Het is ook opgemerkt dat de samenstelling van de olie vrijwel niet verandert tijdens de experimenten met langere verblijftijden.

Proeven in de aanwezigheid van een typische katalysator van vergassing van biomassa onder hydrothermale condities zijn ook beschreven. Echter zijn, tijdens deze experimenten bijna geen positieve effecten van het gebruik van de katalysator op de olieopbrengst en olie samenstelling opgemerkt.

Twee duidelijke koolvormingsmechanismen zijn beschreven en ook twee mechanismen voor de verwijdering van zuurstof uit de olie (dehydratie en decarboxylatie) zijn besproken. De bevindingen zijn gebruikt om het reactiemodel, ontwikkelt voor glucose, uit te breiden voor toepassing met complexe grondstoffen. Daarnaast zijn verschillende katalysatoren gescreend, met pyrolyse olie als grondstof, voor potentiële verhoging van de decarboxylatie opbrengst. Ook het fase gedrag van de HTC reactie producten is visueel waargenomen in speciale testen.

Ten slotte wordt een op labschaal continue reactoropstelling voor HTC voorgesteld. De opstelling is gebaseerd op een wensenlijst die is samengesteld voor veilig, eenvoudig, efficiënt en goedkoop experimenteren. Bepaalde aspecten van de opstelling zijn afzonderlijk getest op kamertemperatuur, zoals de voeding van biomassa/water slurries met een zuiger-autoclaaf en een rijzend wervelbed, warmteoverdracht, het functioneren van het wervelbed en het mengen van vloeibare en vaste fase tijdens continubedrijf. Sommige ervaringen opgedaan tijdens pogingen van experimenten in de continue reactor opstelling onder HTC procescondities worden eveneens besproken. 


\section{Abstrakt}

Tranzicija u društvo u kome su svi procesi obnovivi je cilj i imperativ u modernom svetu. Proizvodnja energije ce imati jednu od najznačajnijih uloga u ovakvom društvu i različite opcije za tu proizvodnju će biti neophodne. Jedna od takvih opcija je korišćenje biomase. Različite rute za transformaciju biomase u kompleksnije izvore energije su pomenute $u$ ovoj tezi. Jedna od takvih ruta je hidro-termalna konverzija biomase (HTC). U ovom procesu, kao reakcioni medijum se koristi tečna voda na povišenoj temperaturi i pod pritiskom (sub-kritična voda). Zbog toga je ova tehnika pogodna za konverziju biomase sa značajnom količinom vode, pri čemu se konverzija vrši iz ekoloških (konverzija otpada) ili ekonomskih (proizvodnja vrednih materijala) razloga. Isparavanje vode i velike utrošak energije koji to iziskuje, može se izbeći u ovom procesu uz pomoć visokog pritiska. Pri tome su u HTC procesu pritisak i temperature ipak niži nego u procesu gasifikacije u superkritičnoj vodi.

Glavna tema ove teze je HTC proces sa ciljem proizvodnje prekursora transportnih goriva. U okviru ove studije razvijena je nova tehnika bazirana na korišćenju kvarcnih kapilara kao šaržnih reaktora, koja omogućava odredjivanje prinosa reakcionih proizvoda u gasovitom, tečnom i čvrstom agregatnom stanju i njihovu naknadnu analizu.

U ovom radu akcenat je stavljen na bitne karakteristike HTC procesa kao što su, formiranje char-a, deoksogenacija, kao i mehanizam i kinetika formiranja kompleksnih proizvoda sortiranih u klase.

Kao prvo, prezentovan je detaljan opis eksperimentalne tehnike i postupka za separaciju i skladištenje reakcionih proizvoda. Pored toga prikazana je i validacija tehnike uključujući statistička razmatranja. U nastavku ova tehnike je korišćena za studiju HTC procesa glukoze. Akcenat je stavljen i na kinetiku inicijalne razgradnje glukoze. Eksperimenti su izvršeni koristeći jedinjenja koja su u literature identifikovana kao primarni proizvodi razgradnje glukoze u HTC reakcijama. Ovi testovi omogućili su identifikovanje izvora gasa i vode proizvedenih u početnoj fazi procesa. Rezultati su pokazali da su svi primarni proizvodi razgradnje glukoze podložni proizvodnji supstance slične uglju (char), iako u različitim razmerama.

Kompletni maseni i energetski balansi su dobijeni za HTC vodenih rastvora glukoze za dve temperature, $300{ }^{\circ} \mathrm{C}$ i $350{ }^{\circ} \mathrm{C}$, različita vremena zadržavanja, od $10 \mathrm{~s}$ do 10 dana, i različite koncentracije. Dobijeni podaci su značajno dopunili postojeće informacije u literaturi HTC procesa glukoze. Uočeni trendovi u brzini i prinosu reakcija su iskorišćeni za formiranje inženjerskog modela razgradnje glukoze.

Nakon toga, istraživanje je usmereno na HTC kompleksnijih materijala, drveta i ulja pirolize. Za ove materijale kompletni maseni i energetski balansi su dobijeni za temperaturu od $350{ }^{\circ} \mathrm{C}$ pri različitim vremenima zadržavanja i koncentracijama. Poredjenjem rezultata 
svih korišćenih reaktanata uočene su sličnosti u prinosu i brzini formiranja reakcionih proizvoda, kao i u njihovom sastavu. Za sva tri korišćena materijala, gotovo sva količina vode je formirana u prvih 5 minuta, dok se količina proizvedenog gasa i char-a povećava monotono u toku procesa, na štetu prinosa ulja, koje je željeni proizvod. Takodje je uočeno da su prinosi gasa i vode nezavisni od koncentracije. Zbog njihovog veoma sličnog atomskog sastava, zaključeno je da su ulje i char, nazvani respektivno WSS i WSIS u sustini isti proizvod, i da je jedina razlika medju njima molekulska masa.

Takodje je primećeno da se sastav ulja gotovo ne menja pri produženju vremena zadržavanja. Katalitički eksperimenti u kojima je korišćen katalizator za gasifikaciju u HTC uslovima su izvršeni, ali nisu pokazali poboljšanje u smislu prinosa ili sastava ulja.

Dva jasno različita mehanizma formiranja char-a su identifikovana i opisana, kao i dva mehanizma uklanjanja kiseonika (dehidratacija i dekarboksilacija). Uz pomoć podataka dobijenih pri konverziji sva tri materijala, inženjerski model razgradnje glukoze je proširen za korišćenje u slučaju kompleksnih reaktanata. Takodje, eksperimenti sa izvesnim brojem katalizatora su izvršeni koristeći ulje pirolize u cilju poboljšanja dekarboksilacije ulja pirolize. Uz to je, u specijalnim testovima, izvršena i kvalitativna analiza separacije faza proizvoda HTC reakcija.

Na posletku je predložen bench-scale kontinualni reaktorski system za HTC proces. Ovaj system je baziran na listi zahteva koji omogućavaju bezopasno, jednostavno, efikasno i jeftino eksperimentisanje. Odredjene osobine ovog reakcionog sistema, su nezavisno testirane na sobnoj temperature, kao npr. sistemi za transport suspenzija biomase u vodi: klipni autoklav i pokretni fluidizovani sloj, razmena toplote, operacija u fluidizovanom režimu, mešanje tečnosti i čvrste faze u kontinualnom režimu. Takodje su opisane i pojedine obzervacije tokom pokušaja hot-flow eksperimenata. 
CHAPTER 1

Introduction 


\section{Sustainable Energy and Biomass}

For the future of mankind it is essential to make all processes of men sustainable. This should also include all technological processes. Energy generation is one of the most important technical processes for which technological solutions need to be developed. Except for nuclear and tidal energy, the overwhelming majority of energy generated by man originates directly or indirectly from solar radiation $\left(>90 \%{ }^{1,2}\right)$. Fossil fuel, which is fossilized solar radiation energy captured by plants in past eons, is providing the largest part of the energy generated today $(\sim 80 \%)^{2}$. Fossil fuel cannot be considered renewable or sustainable due to the finite reserves and environmental load via emissions of greenhouse gases, mainly $\mathrm{CO}_{2}$. In addition, the security of provision of fossil fuel is questionable. Renewable and sustainable energy sources, mainly directly or indirectly based on solar radiation (photovoltaic, wind, etc.) currently receive a lot of attention.

One of these sources is biomass. Due to its short carbon cycle it does not necessarily have a net contribution to the accumulation of $\mathrm{CO}_{2}$ in the atmosphere. Provided it could be used in a sustainable way, biomass could contribute $20-30 \%$ of the energy generation of mankind. At present biomass provides $\pm 13 \%$ of the energy provision, but this is nearly all traditional utilization for cooking and heating in developing countries. For a large fraction of the human population (> $40 \%$ ) biomass is the only source of energy.

It is expected that a large fraction of agricultural and forestry waste, which is equivalent to $50 \%$ of the world crude oil production) ${ }^{3}$ can be made available for energy purposes while avoiding undesired food \& feed/ energy competition. On the longer term, cultivation of highly efficient energy crops could be considered.

To a certain extent biomass can be (co)fired, without much pretreatment, in modern equipment next to fossil fuel, like in electricity generation in coal-fired power stations (green electricity). However, much of $R \& D$ effort is nowadays devoted to converting biomass to improved energy carriers, equivalent to, or better than, the present fossil based fuels.

\section{Biomass as Fuel}

Although it is a common source of energy (especially in developing countries), biomass as such is not an ideal fuel due to its fibrous nature, low density and low heating value. Therefore biomass is treated in various processes to create products which can be efficiently and economically utilized in modern energy equipment. For oil from seeds, relatively simple conversion processes, like transesterification, can be used to obtain an acceptable diesel fraction. Sugar from cane or beets and starch are used for biological 
conversion to ethanol. In the future, the lignocellulosic remains of plants, such as agricultural and forestry waste (wood, bark etc.) should be used for energy purposes as these are not in direct competition with biomass for food and feed.

Lignocellulosic material mainly consists of cellulose, hemicellulose and lignin (see Figure 1). Cellulose is a linear homopolymer of glucose units, while hemicellulose is a co-polymer of penthoses and hexoses. Lignin consists of aromatic units linked together in large structures. In biomass waste materials, other components like fat, proteins etc. will also be present.
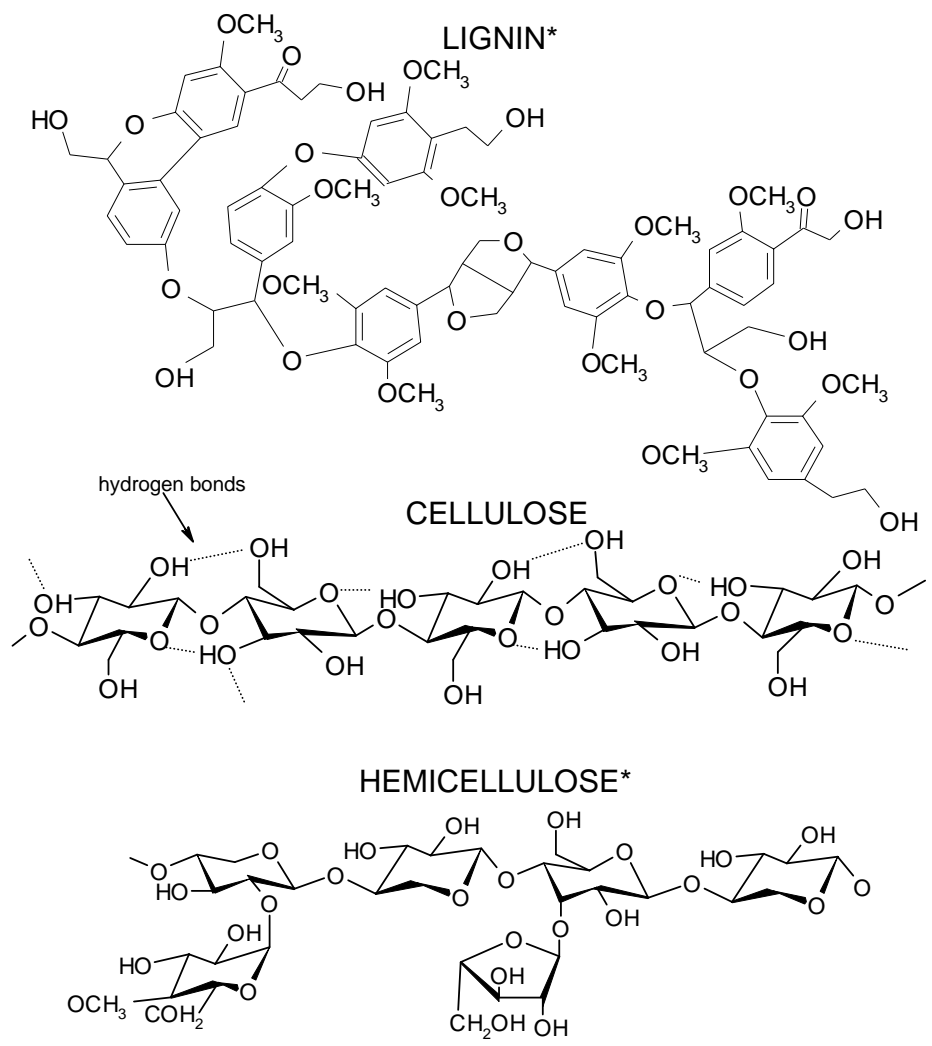

* elements of structure

Figure 1. Building blocks of lignocellulosic biomass.

Biomass is nearly always a solid material containing water in a highly variable amount. Compared to many fossil fuels it has a high oxygen content (e.g. typically $39-44 \mathrm{wt} \%$ for wood $^{4,5}$ ). Biomass may also contain a small to intermediate amount of elements like: P, N, $\mathrm{K}, \mathrm{Na}$, Ca etc. 
Unlike many fossil fuels, biomass is not available in highly concentrated point sources, but has to be gathered from large areas which can be a problem for a solid material of a typically low bulk density (say $100-500 \mathrm{~kg} / \mathrm{m}^{3}$ ).

In the future, when agricultural products may be converted in bio-refineries, producing food/feed, chemicals and energy, the collection and transport situation of biomass for energy may change drastically.

In the coming decades, whatever the source and type of biomass is, there will be a demand for improving/upgrading the biomass to fuels that can be converted in modern energy generating equipment, preferably while blending with fuels from fossil sources.

\section{Conversion Technologies for Improved Fuels from Biomass}

Conversion processes are available or under development for both wet and dry feedstocks. Examples of wet biomass are: sewage sludge, sugar solutions, algae suspensions, waste streams from biomass processing, or from biorefineries. Dry biomass commonly has low moisture content (say less than $30 \mathrm{wt} \%$ ). Examples of dry biomass are: wood, straw, or other sun dried waste. Of course wet biomass can be dried with energy from other sources, but this is not always the most efficient or economical way to operate.

Mechanical treatment and compacting could be used efficiently close to the production sites and is applied for e.g. pressing the oil from the oil rich seeds. For this latter purpose, also extraction with hexane or supercritical $\mathrm{CO}_{2}$ can be applied.

For dry biomass apart from combustion, fast or slow pyrolysis can be applied to produce an oil like substance, char or gas. Also gasification to fuel gas or to syngas for production of synthetic fuel is a possible route. Moreover, solvolysis using organic solvents can be applied. ${ }^{6,7}$

Different combinations of pretreatment, intermediate conversion and final conversion can be used depending on local options and/or economics, as indicated in Figure 2.

In fast pyrolysis process (see, e.g., Bridgwater et al. ${ }^{8}$ ) biomass is quickly heated to say 500 ${ }^{\circ} \mathrm{C}$ and the vapors are rapidly quenched to produce a liquid (up to $70 \mathrm{wt} \%$ of the biomass), which, after stabilization, can be stored and transported, used as such, or further refined. The liquid product still contains a large amount of oxygen ( \pm 40-50 \%). Fuel gas and char are produced as byproducts, parts of which can be used to energize the process. 


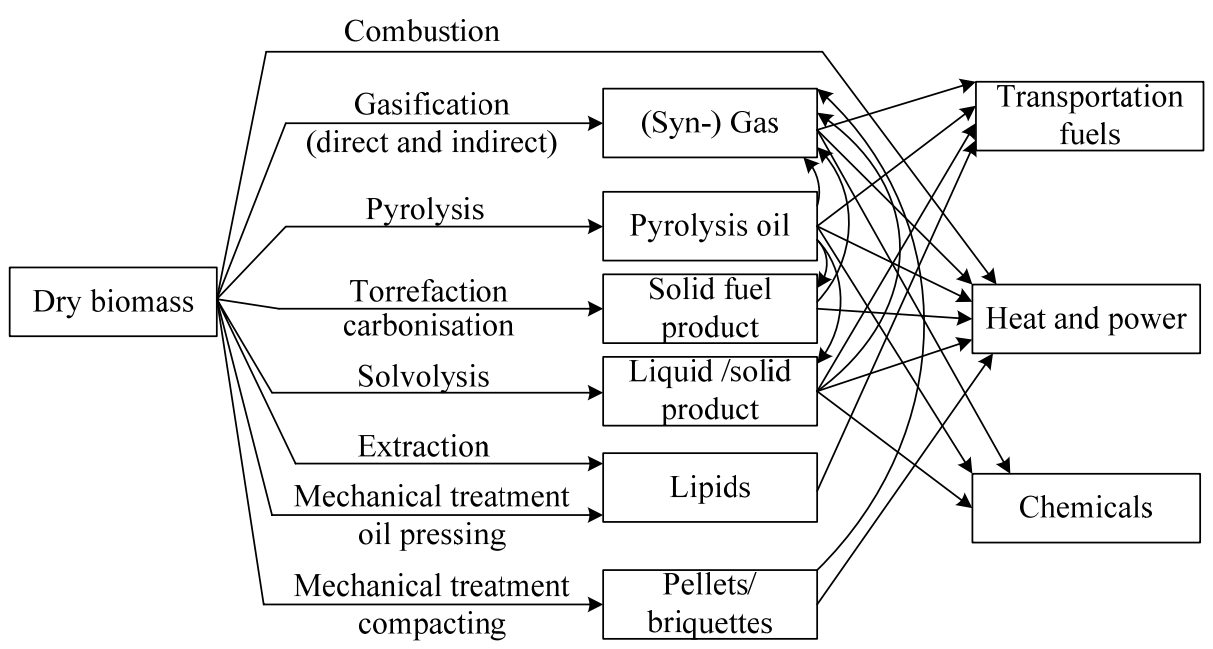

Figure 2. Conversion and utilization options for biomass with low moisture content.

Wet biomass (see Figure 3) can be converted into improved fuels via biological routes, e.g., anaerobic digestion to methane rich gas, or fermentation to alcohols. Conventionally these routes are limited to certain carbohydrate fractions of biomass. However, for the so called second generation conversion processes, enzymes and pretreatment options are being developed that target the lignocelulosic biomass in broader sense. ${ }^{9}$

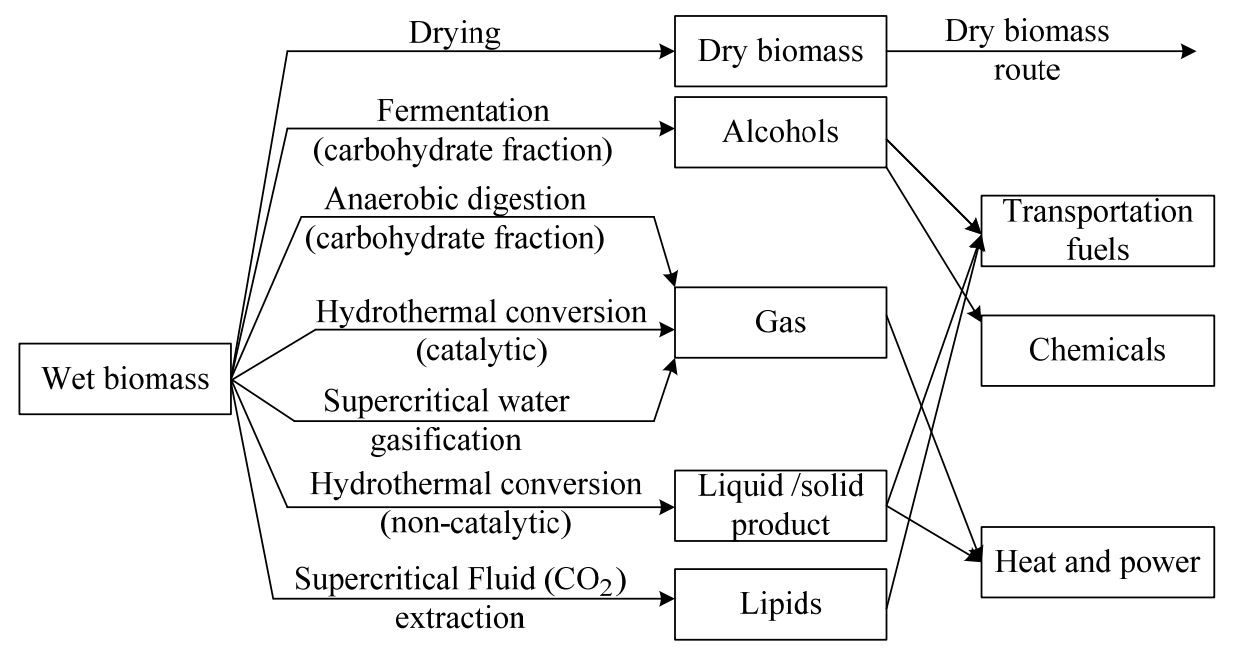

Figure 3. Conversion and utilization options for wet biomass. 
For wet biomass conversion, processes which do not require water evaporation are desired. Next to biological conversion also conversion in hot compressed water, both sub- and super-critical, is possible aimed at the production of hydrophobic liquids, solids and gasses (see, e.g., Goudriaan et al. ${ }^{10}$, Elliott et al. ${ }^{11}$ ).

Apart from hot compressed water, other solvents have been used for biomass conversion. ${ }^{12-}$

${ }^{16}$ However, this is not a topic of the present work.

By combining dry and wet conversion routes, a wide spectrum of interconnected thermochemical biomass conversion routes towards final products are possible, e.g. in a biorefinery. In such a complex concepts, hydrothermal conversion can be applied to produce intermediate energy carriers, in primary conversion steps like gasification and deoxygenation; or it can be used for working up of side/ waste streams from conversion processes of biomass to food, feed, or chemicals.

\section{Short Description of Hydrothermal Conversion}

Hydrothermal conversion (HTC) is a thermo-chemical conversion technique which uses liquid sub-critical water as a reaction medium for conversion of wet biomass and waste streams.

As shown in Figure 4, HTC can be performed with various purposes and different products can be aimed for. In a catalytic version of the process almost complete conversion of biomass to methane rich gas is realized. ${ }^{17}$ However, here we will concentrate mainly on non-catalytic HTC.

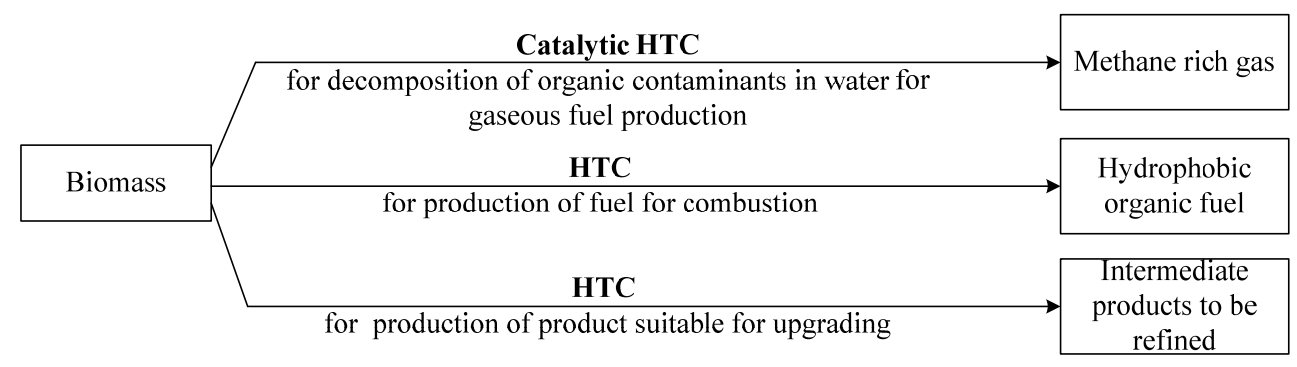

Figure 4. Different HTC options.

Figure 5 presents a scheme of a typical HTC process. Prior to feeding into the process, biomass is pretreated to ensure that the feedstock has desired properties: rheological properties, water content, degree of fragmentation of biomass components etc. 


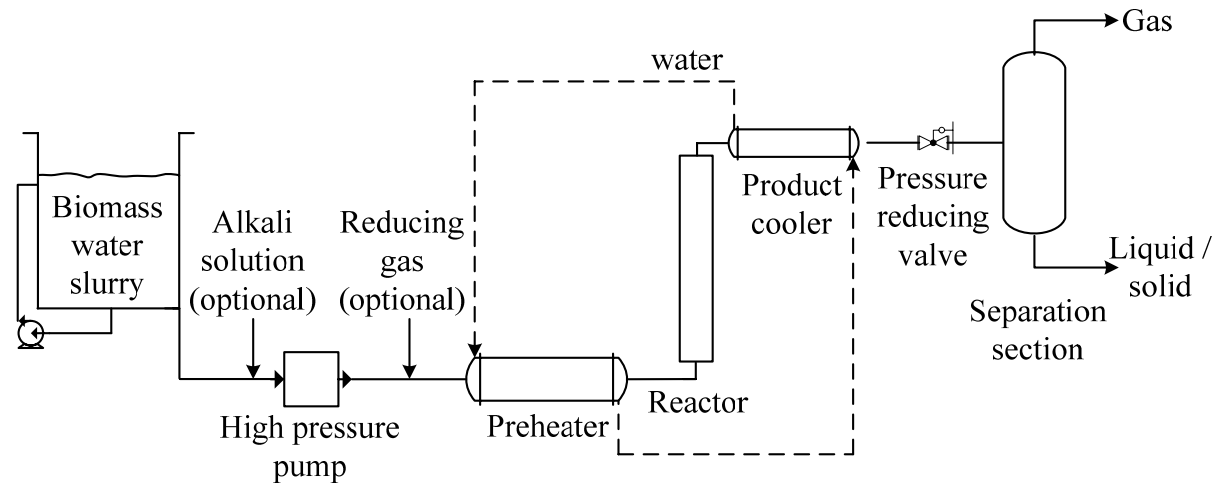

Figure 5. Typical HTC process layout.

In the feeding section, feedstock is pressurized and heated to the desired temperature, while being transported to the reactor. Feeding biomass water slurries is a particular challenge due to the problems of biomass settling and filtering and blocking of the process lines, particularly for relatively high biomass/water ratios. Heating to desired temperature in the range of 300 to $370{ }^{\circ} \mathrm{C}$ is performed while water is kept in liquid phase by pressure regulation. ${ }^{18,19}$ In most cases tubular reactors have been used for continuous installations. Typically, residence times of 5-90 minutes have been applied. ${ }^{10,12,20,21}$ Upon cooling the reactor effluent of HTC, three different products, being also three different phases at room temperature, can be identified: a hydrophobic organic phase, an aqueous phase with organic compounds dissolved in it, and a gas phase, consisting mainly of $\mathrm{CO}_{2}{ }^{10,22}$

A direct application of HTC products is as combustion fuels. In this process option, HTC yields hydrophobic organic products (sometimes called biocrude ${ }^{10}$ ) which are easy to separate from the water phase and can be burned directly as fuel in boilers and furnaces. ${ }^{6,22}$ These products can also be further fractionated by means of extraction with polar organic solvent(s). ${ }^{23-27}$ The solvent-soluble fraction is then the desired product, part of which can be upgraded to transportation fuel quality by catalytic hydro-deoxygenation. ${ }^{10,12,28,29}$ The production of an intermediate suitable for refining and upgrading into transportation fuel is the preferred aim of HTC. Therefore this option is intensively studied, with the focus on minimizing the yields of the reaction byproducts and on the product separation.

For environmental remediation and/or energy recovery from organics in water, a special catalytic HTC process can be used. In this concept, organic streams (for example: in industrial or household wastewater) are completely converted into methane rich gas. ${ }^{11,30}$ 


\section{Historical Overview of Hydrothermal Technology Development}

For detailed overview of liquefaction activities until 1990's reader can refer to Moffatt and Overend, ${ }^{29}$ Bouvier et al. ${ }^{31}$, Stevens et al. ${ }^{32}$ and Solantausta et al. ${ }^{33}$ Here we focus only on an overview of the most significant pilot plant work and known or claimed commercial activities.

In the 1970's and 1980's the interest in alternative energy sources, such as biomass, was high due to the oil crises. The liquefaction research started in 1971 by the US Bureau of Mines ${ }^{18}$ with conversion of carbohydrates in hot compressed water in the presence of CO and $\mathrm{Na}_{2} \mathrm{CO}_{3}$. This combination of $\mathrm{CO}$ and $\mathrm{Na}_{2} \mathrm{CO}_{3}$ was considered necessary in the early HTC developments for producing hydrogen in situ ${ }^{18}$, until Molton et al. ${ }^{34}$ showed that the use of CO in combination with alkali leads to a limited increase in the oil yield. This was later on confirmed by others. ${ }^{23,35,36}$

Early work by the US Bureau of Mines led to the development of a $18 \mathrm{~kg}$ wood per hour process development unit (Albany pilot plant). ${ }^{37}$ In this installation liquefaction of Douglas fir was performed using the oil product itself (PERC process) or water (LBL process) as a carrier. For the LBL process, slurries, formed from acid pre-hydrolyzed wood chips and water, were used as feedstocks. Operating problems led to several process modifications. However, not all issues were completely successfully resolved. ${ }^{38}$ This, along with a large number of parameters that needed to be studied, ${ }^{39}$ caused a shift to research in a much smaller scale (continuous $1 \mathrm{l}$ autoclave). ${ }^{20,39}$

HTC using biomass/water slurries of high organic/water ratios was studied at the University of Arizona ${ }^{40-42}$ and the University of Saskatchewan ${ }^{43-45}$ by using special feeding systems.

Another important development involved sewage sludge treatment in so called Sludge to Oil Reactor System (STORS). This process was developed using autoclaves and continuous installation with the capacity of $30 \mathrm{~kg}$ of concentrated sewage sludge (20 wt\% solids) per hour in the Battelle Pacific Northwest laboratories of the US Department of Energy. ${ }^{21}$ As catalyst sodium carbonate was used.

After a period of reduced attention, the interest in conversion of biomass into energy carriers was renewed in the mid 1990's driven by political, environmental and economical incentives. For example, work on the Hydro-Thermal Upgrading (HTU ${ }^{\circledR}$ ) process, developed during 1980's in the Shell Laboratories in Amsterdam, was restarted using a bench scale experimental setup (10 kg water-biomass slurry per hour ${ }^{10}$ and a pilot plant (20 kg dry matter per hour). ${ }^{22}$ Currently the research phase is completed and plans are made for realization of the first demonstration plant. ${ }^{46}$

Next to the pilot plant studies, laboratory scale research on catalytic and non-catalytic HTC has been performed all over the world. ${ }^{47-58}$ Also several demonstration and (semi) commercial activities can be identified. 
Five tons per day STORS process demonstration plant was built in $\operatorname{Japan}^{59}$ with the aim of converting sewage sludge into a combustible energy carrier. After a successful municipal wastewater treatment STORS demo project in Colton, California, ${ }^{60,61}$ ThermoEnergy (US) has patented $^{62}$ the improved wastewater treatment process marketed under the name "Thermofuel process".

EnerTech Environmental Inc. ${ }^{63}$ (US) is also developing a process for converting sewage sludge into an energy carrier, a so called "Slurrycarb process". The company operates a 1 ton/day process development unit; a 20 tons/day process demonstration unit in cooperation with Mitsubishi Corporation in Ube City (Japan) and is currently constructing a commercial scale facility in Rialto, California. ${ }^{63}$ When completed, the installation will convert more than 880 wet tons of bio-solids per day from five municipalities in the Los Angeles area into approximately 170 tons per day of the product called E-Fuel.

A number of heterogeneous catalysts were tested under the HTC conditions for conversion of organic feedstocks to gasses and breakdown of hazardous organics. ${ }^{64-66}$ The developed concept is licensed to Onsite*Ofsite, Inc and is being commercialized since 1990's under the name TEES $^{\circledR}$ (Thermo-chemical Environmental Energy System) with practical solutions involving several designs among which mobile bio-waste destruction units of 10$20 \mathrm{~L} / \mathrm{h}$ and commercial design of units with a capacity of up to 0.378 million L/day. ${ }^{67}$

Changing World technologies was developing a so called Thermo-Depolymerization and Chemical Reformer process for conversion of turkey waste (carcasses) to fuel products and fertilizer. The company used a 15 ton/day pilot plant and 200 ton/day processing unit (the Renewable Environmental Solution unit in Carthage, Missouri). ${ }^{68}$ However, work has recently (as of February 2009) been discontinued due to financial difficulties. ${ }^{69}$

From this overview it appears that HTC of specific feedstocks to hydrophobic fuels for combustion is nearing commercial operation. On the other hand, application of HTC for broader range of feedstocks and for production of transportation fuel precursors is still in development stage.

\section{HTC Reaction Chemistry}

\section{Pretreatment}

Prior to HTC, biomass can be pre-treated in order to produce uniform and pumpable waterbiomass slurries and achieve fractionation and partial decomposition. During this process, physical changes of biomass such as wetting, swelling and pre-hydrolysis take place. Experience from pulping technologies of the paper production industry has been used in developing some chemical (acid/base) pretreatment methods. ${ }^{19}$ The principle of steam 
explosion ${ }^{70}$ followed by acid treatment has equally been applied for homogenizing biomass-water slurries. ${ }^{71}$ Techniques based on physical disruption of biomass structure can also be used. White and Wolf ${ }^{40-42}$ describe the usage of extruder like devices with combining effects of hydrolysis, thermolysis and shear stress. Investigations have been performed of specially designed valves for disruption of the biomass fiber network. ${ }^{72,73}$

Reviews of pretreatment options for lignocellulosic biomass are available from McMillan et al. $^{74}$ and Mosier et al. ${ }^{75}$

\section{Decomposition and Recombination}

For detailed overview of the chemical reactions in hot compressed water, reader can refer to literature reviews. ${ }^{76-78}$ From these reviews it is clear that the chemistry of HTC is extremely complex. Nevertheless, all HTC reactions can be classified according to their mechanism: ionic and free-radical reactions. ${ }^{6,79}$

Hydrolysis, a class of decomposition reactions of organics involving breakdown by water, are typical ionic reactions catalyzed with bases or acids. These reactions readily occur already in the temperature range of 150 to $250^{\circ} \mathrm{C}$ when autocatalysis is caused by acidic HTC reaction products. ${ }^{6,7}$ The extent of hydrolysis of biomass constituents depends on the temperature. Generally, hemicellulose undergoes hydrolytic decomposition the easiest (already at temperatures from 120 to $180^{\circ} \mathrm{C}$ ); hydrolysis of cellulose occurs readily at different temperatures (typically above $\left.180^{\circ} \mathrm{C}\right)^{80}$ depending on its structure; while only partial hydrolysis of lignin is possible under HTC conditions without catalyst. ${ }^{81}$ Complete dissolution of whole biomass was, however, recently demonstrated with $\mathrm{Na}_{2} \mathrm{CO}_{3} \cdot{ }^{82}$

Ionic reactions are accompanied/followed by free radical decomposition reactions. These thermal decomposition reactions in the absence of oxygen are named pyrolysis. The reactions are favored over ionic reactions at lower pressures, lower densities (gasses) and higher temperatures. ${ }^{54,79,24}$ Susceptibility of biomass constituents towards thermal degradation also decreases in the order: hemicelluloses, cellulose, (only part of) lignin. ${ }^{83,84}$ Due to its aromatic structure, only part of the lignin can be decomposed under non-catalytic HTC conditions. Moreover, it is also proposed that free phenoxyl radicals, formed by thermal decomposition of lignin under HTC conditions above $250{ }^{\circ} \mathrm{C}$, are particularly susceptible to recombination. ${ }^{82,49}$ The recombination HTC reactions are disadvantageous if the product is meant for upgrading to transportation fuels. These polymerization and polycondensation reactions lead to the increase of the average molecular weight and eventually lead to the formation of a fraction which can only be used for its heating value (commonly named: char). Molecular weight distribution can therefore be a useful indicator for process optimization. 


\section{Deoxygenation}

In Figure 6 the location of various organic materials is given in a CHO plane. The net effects of several thermo-chemical conversion processes are indicated with arrows. It can be seen that these processes yield products which, in terms of the elemental composition, approach the ideal crude oil fuels. This is due to the oxygen removal. Under the HTC conditions this can, to a certain extent, be realized without the use of reducing gasses like CO or hydrogen, a fact which is often stated as one of the major advantages of this technique. Depending on the operating conditions and the feedstock, oxygen contents of hydrophobic phases as low as 5-15 wt\% are reported in literature. ${ }^{10,12,20}$

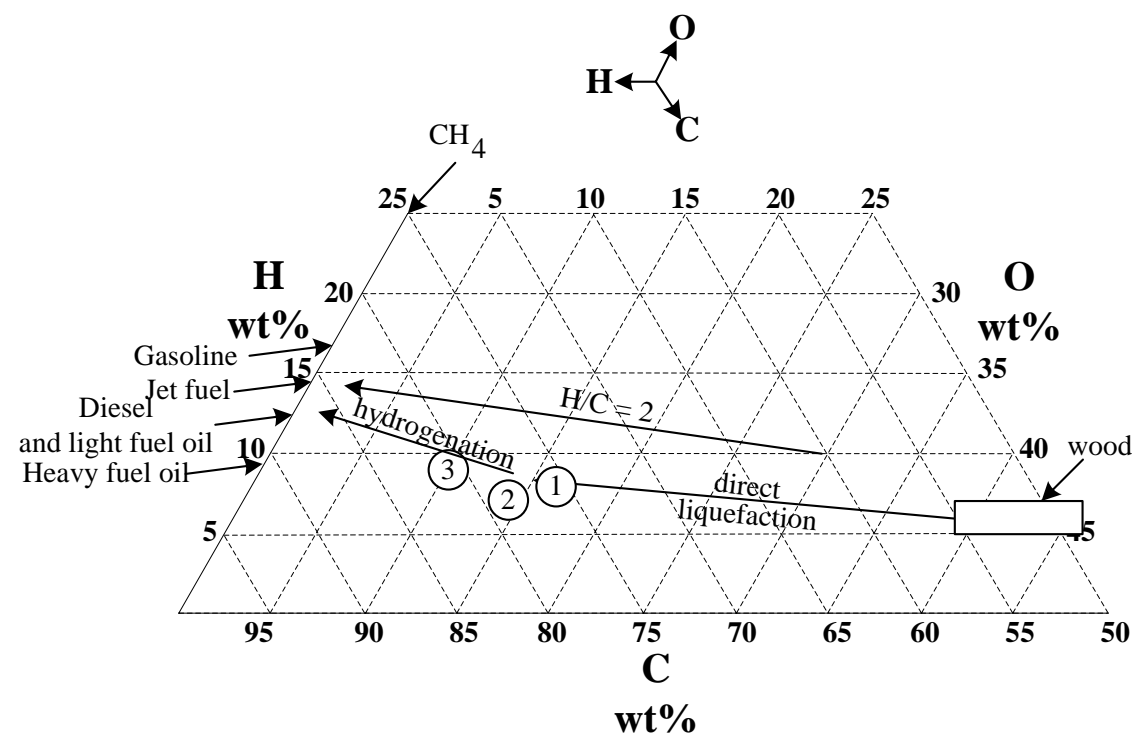

Figure 6. High pressure HTC and hydrogenation processes and products in ternary C-H-O diagram (modified from: Wilhelm et al. ${ }^{12}$ ) 1 - PERC process ${ }^{37}, 2$ - LBL process, ${ }^{20} 3-$ HTU $^{\circledR}$ process. $^{10}$

Oxygen removal under the HTC conditions occurs via the following reactions: dehydration, decarboxylation and decarbonylation. However, $\mathrm{CO}$ added to the reactor or formed in the reactions, is largely converted to $\mathrm{CO}_{2}$ in the water gas shift or reduction reactions. Therefore, the net effect of deoxygenation during the $\mathrm{HTC}$ is the $\mathrm{CO}_{2}$ and $\mathrm{H}_{2} \mathrm{O}$ formation, the first one being more favorable, as the molecular $\mathrm{H}$ over $\mathrm{C}$ ratio $(\mathrm{H} / \mathrm{C})$ of the product is not reduced in this way. Furthermore, water is a product of polycondensation reactions which are one of the main routes towards char. ${ }^{54,85}$ Direct comparison of these two routes of oxygen removal is a challenge due to difficult determination of water production. This involves either direct determination by Karl-Fisher titration or indirect calculation from elemental balances. Both these methods can be highly inaccurate, first one, due to the 
determination of small change in a large amount of water; and the second one, due to the accumulation of measurement errors in the calculation process.

\section{Role of Water}

Water under the HTC conditions has several different roles. It is a reaction medium and can serve as a distribution medium for homogeneous and heterogeneous catalysts. Moreover, water itself has a catalytic role in various acid/base catalyzed processes due to its higher degree of ionization at the increased temperature. According to the transition state theory, the presence of water in some organic reactions (also some hydrolysis and decarboxylation reactions) can cause a decrease of the activation energy, thus affecting their kinetic. ${ }^{77}$

Water is also directly involved in chemical reactions under the HTC conditions. Next to hydrolysis, water can oxidize some organic species in both the liquid (e.g. alcohols to ketones) and the gaseous phase (e.g. $\mathrm{CO}$ to $\mathrm{CO}_{2}$ in the water gas shift reaction). The role of water in hydrogen transfer reactions was verified by the use of deuterium water. ${ }^{77}$

Under the HTC conditions water is a powerful polar organic solvent due to the strong decrease of its dielectric constant with temperature. ${ }^{77,86}$ Water molecules isolate the reaction intermediates and serve as a physical barrier between them. In this way the reaction intermediates are stabilized, which is essential if the fuel precursor is aimed for (see Figure 4).

\section{Experimental Results and Methods of Previous Research}

Despite extensive scientific and commercial efforts, theory of HTC remains insufficiently developed. There are a several reasons for this. The number of sources which give full mass and elemental balances (thus, detailed product composition) is limited (see Chapter 3). Various aspects of the process such as: oxygen removal; fouling and blocking due to char formation have been identified but not fully understood. This is to a certain extent caused by the complex nature of HTC which operates at harsh conditions (temperature, pressure, corrosion, fouling). Therefore researchers often took an original approach in experimentation which causes complications in data comparison. Researchers have used different feedstocks, reactor systems, process conditions and workup procedures. For example, in some investigations natural separation is used for product separation (see, e.g., Goudriaan et $\mathrm{al}^{22}$ ) leading to the formation of separate water soluble and water insoluble product fractions. Other researchers used organic solvents which led to a different definition of the products and distinction between for example solvent soluble (oil) and solvent insoluble (char) fraction (see, e.g., Ogi et al. ${ }^{24,26,51}$ ). Also the choice of reactors and process conditions was widely different. Developments are usually based on expensive 
continuous pilot plants of relatively large scale. In this kind of systems the study and the demonstration of solving important technical barriers like high pressure slurry pumps, fouling of heat exchangers and reactors, phase separation control, deposits etc. become costly and time consuming.

Other types of experiments are batch autoclave tests in which heating and cooling may be integral parts of the test and translation to continuous operation problematic. Special solutions like cold feedstock injection in a large batch of hot compressed water will create rapid heating. However, with this approach only low biomass to water ratios are possible and the conditions of macro mixing are difficult to understand.

In addition, reactor systems with different time constants allowed only a certain window of operation to be investigated leading to complications in data interpretation. For example, residence time and temperature regions sometimes overlapped only partially, leading to seemingly contradictory conclusions about the process, while, in fact, different process stages were studied. As an example to illustrate this, in different HTC studies using $\mathrm{Na}_{2} \mathrm{CO}_{3}$, the increase in residence time has been linked with monotonous increase, ${ }^{35}$ decrease, ${ }^{24}$ or no effect ${ }^{87}$ on the yield of the desired oil product. Similarly, increase in residence time has been reported to increase ${ }^{24}$ or slightly decrease ${ }^{87}$ the char yield during HTC.

Although several researchers have proposed reaction mechanisms and pathways, a quantitative reaction model has not been established to date. The difficulty of modeling the HTC may be caused by the fact that conventional approach to this study is not possible since simple reaction quantifiers such as: the degree of conversion, selectivity etc. cannot rationally be used as such for integral biomass.

Finally, studies of catalytic HTC have typically been performed in reactors made of special steels, often containing metals like nickel, which have catalytic properties under hydrothermal conditions. This may complicate the small scale studies.

\section{Present Investigation}

The aim of the present investigation was to establish an operating window for HTC used for production of intermediates suitable for further refining to transportation fuel by producing data as complete as possible, establishing an engineering reaction model and contributing to understanding of several process properties, such as, char formation, deoxygenation, effect of mixing etc.

For this purpose, a new high throughput batch micro reactor testing method using quartz capillaries was developed, which allowed nearly isothermal operation in the reactors with 
inert, transparent walls. The possibility of visual observation allowed for the first time observation of the process at elevated temperature and pressure. This allowed various qualitative conclusions about HTC reactions and product separation. Using this technique, with its analysis system, full mass and elemental balances were obtained for HTC of biomass (wood) and a biomass model compound (glucose).

The differences between pyrolysis and hydrothermal conversion are also demonstrated and elucidated, directly showing the role the compressed water plays in the HTC process. HTC of integral pyrolysis oil as a special feedstock was studied as a possible means of stabilizing the oil and removing large parts of its water content.

Primary and secondary char formation mechanisms have been identified and studied, as well as the kinetics of oxygen removal. Findings on the product yields and composition of the HTC of glucose are summarized in a lumped component engineering reaction model, in which the reaction products are lumped in appropriate product classes. The model is extended to some other feedstock materials.

The role of heterogeneous and homogeneous catalysis is studied in a few scouting experiments.

Finally, several additional studies were performed in order to downsize a continuous HTC plant to a table top scale in order to decrease cost of experimentation and improve operation flexibility.

Items studied were: (slurry) feeding system, possibility of elimination of a high pressure flash valve, heat transfer and temperature profile, possibility of gas formation as a separate phase, and fluid bed operation simulating a fluidized heterogeneous catalyst. Finally, a stirring device was tested to change the state of macro mixing (CSTR vs. plug flow) in a small tubular reactor.

A research path parallel to the present work and financed by the same national program "BIOCON" was focused primarily on reaction chemistry and has been performed at the University of Delft. It has also resulted in a $\mathrm{PhD}$ thesis. ${ }^{88}$

\section{Content of the Thesis}

In Chapter 2 the new experimental method is introduced. Chapters 3 and 4 deal with the conversion of: glucose, wood (integral biomass), and pyrolysis oil (biomass conversion product) in quartz capillaries. Glucose conversion is characterized with an initial degradation model, which is verified using own results. Initial degradation products were identified and workable engineering reaction model is developed. In Chapter 4 features of the HTC process which are independent of the feedstock are described, along with some feedstock related specific characteristics. Modifications of the reaction model, presented in chapter 3 , are suggested to allow its use with any feedstock. In-depth study of the formation 
of char and water as by-products is given. chapter 5 presents the developments on the process downsizing: feeding section, product collection, cold flow characterization of the mixing in a homogeneous reactor system and fluidized bed. Finally, in chapter 6 conclusions and some recommendations for the process development are given. 


\section{References}

${ }^{1}$ Bent SørensenRenewable Energy Its physics, engineering, use, environmental impacts, economy and planning aspects, 3rd edition, Elsevier science and technology books, ISBN: 0-12-656153-2

${ }^{2}$ IEA: Key world energy statistics: 2008

${ }^{3}$ Groeneveld, M.J.: Private communication

${ }^{4}$ Domalski, E.S.; Jobe, T.L. Jr ; Milne, T.A.Thermodynamic Data for Biomass Conversion and Waste Incineration, 1986 Sep 01, Technical Report Report Number(s): SERI/SP-271-2839.

${ }^{5}$ Jenkins, B.M.; Baxter, L.L.; Miles Jr., T.R.; Miles, T.R Combustion properties of biomass. Fuel Processing Technology 1998, 54, 17.

${ }^{6}$ Chornet, E.; Overend, R.P. Biomass liquefaction: An overview. In: Fundamentals of Thermochemical Biomass Conversion (edited by Overend, R.P.; Milne, T .A.; Mudge, L.K.), Elsevier Applied Science, 1985, pp.967.

${ }^{7}$ Behrendt, F.; Neubauer, Y.; Oevermann, M.; Wilmes, B.; Zobe, N. Direct Liquefaction of Biomass (review) Chemical Engineering \& Technology 2008, 31, 667.

${ }^{8}$ Bridgwater, A.V. Principles and practice of biomass fast pyrolysis processes for liquids. Journal of Analytical and Applied Pyrolysis 1999, 51,3.

${ }^{9}$ Iogen: a leader in cellulose ethanol Bio-Prospects 2005 Volume 2, 1, Published by Ag-West Bio Inc

${ }^{10}$ Goudriaan, F.; Peferoen, D. G. R. Liquid fuels form biomass via a hydrothermal process. Chem. Eng. Sci. 1990, 45, 2729.

${ }^{11}$ Elliott, D. C.; Silva, L. J. The TEES process cleans waste and produces energy. Presented at the $R$ 1995 Conference, Geneva, Switzerland, 1-3 Feb. 1995.

${ }^{12}$ Wilhelm, D. J; Kam, A.Y.; Stallings, J. W. Transportation fuel from biomass by direct liquefaction and hydrotreating. Symposium papers: Energy from biomass and wastes $V$, January 26-30, 1981, Lake Buena Vista, Florida, USA, pp.651.

${ }^{13}$ Vasilakos, N.P.; Austgen, D.M. Hydrogen-Donor Solvents in Biomass Liquefaction. Ind. Eng. Chem. Proc. Res. Dev 1985, 24, 304.

${ }^{14}$ Heitz, M.; Brown, A.; Chornet, E. Solvent Effects On Liquefaction: Solubilization Profiles of a Canadian Prototype Wood, Populus deltoids, in the presence of different solvents. Can. J.Chem. Eng. 1994, 72, 1021.

${ }^{15}$ Rezzoug, S. A.; Capart, R. Solvolysis and hydrotreatment of wood to provide fuel. Biomass and Bioenergy 1996, 11, 343.

${ }^{16}$ Mun, S. P.; Hassan, E. B. M. Liquefaction of Lignocellulosic Biomass with Dioxane/Polar Solvent Mixtures in the Presence of an Acid Catalyst. J. Ind. Eng. Chem. 2004, 10, 722.

${ }^{17}$ Elliott, D.C.; Neuenschwander, G. G.; Hart, T.R.; Butner, R. S.; Zacher, A. H.; Engelhard, M.H.; Young, J. S.; McCready, D. E.Chemical Processing in High-Pressure Aqueous Environments. 7. Process Development for Catalytic Gasification of Wet Biomass Feedstocks. Ind. Eng. Chem. Res. 2004, 43, 1999. 
${ }^{18}$ Appell, H.R.; Fu, Y.C.; Friedman, S., Yavorsky, P.M.; Wender I. Converting organic wastes to oil: A replenishable Energy Source. Bureau of Mines Report of Investigations, 7560, 1971.

${ }^{19}$ Annee, J. H. J.; Ruyter, H. P. Process for Producing Hydrocarbon containing Liquids from Biomass. European patent number 0204354, 1986.

${ }^{20}$ Figueroa, C.; Schaleger, L.L.; Davis, H.G. LBL continuous bench-scale liquefaction unit, operation and results. In: Conference proceedings: 6. annual conference on energy from biomass wastes, Lake Buena Vista, FL, USA, 25 Jan 1982, pp. 541.

${ }^{21}$ Molton, M.P.; Fassbender, A.G.; Robertus, R.R.; Brown, M.D.; Sullivan, R.G. Thermochemical conversion of primary sewage sludge by STORS process. In: Research in Thermochemical Biomass Conversion (edited by Bridgwater, A.V. and Kuester, J.L.) Elsevier Applied Science, 1988; pp 867882.

${ }^{22}$ Goudriaan, F.; Van de Beld, B.; Boerefijn, F. R.; Bos, G. M.; Naber, J. E.; Van der Wal, S.; Zeevalkink, J. A. Thermal efficiency of the HTU Process for biomass liquefaction. In Proceedings of the conference: Progress in Themochemical Biomass Conversion (edited by Bridgwater, A. V.), Blackwell Science: England, 2000; pp 1312.

${ }^{23}$ Yokoyama, S-Y; Ogi, T; Koguchi, K; Nakamura, E. Direct liquefaction of wood by catalyst and water. Petroleum Science and Technology 1984, 2,155.

${ }^{24}$ Ogi, T.; Yokoyama, S-Y.; Kuguchi K. Direct liquefaction of wood by catalyst part I. Effect of pressure, temperature, holding time and wood/catalyst/water ratio on oil yield, Sekiyu Gakkaishi $198528,239$.

${ }^{25}$ Krochta, J.M.; Hudson, J.S.; Drake, C.W.; Mon, T.R.; Pavlath, A.E. Thermal Degradation Of Cellulose in Alkali. In: Fundamentals of Thermochemical Biomass Conversion: An International Conference, Estes Park Colorado, 1985, pp. 1073.

${ }^{26}$ Ogi, T.; Minowa, T.; Dote, Y.; Yokoyama, S-Y. Characterization of oil produced by the direct liquefaction of Japanese oak in an aqueous 2-propanol solvent system. Biomass and Bioenergy 1994, 7, 193.

${ }^{27}$ Cheng, L.; Ye, P., X; He,R.; Liu, Sh. Investigation of rapid conversion of switchgrass in subcritical water. Fuel processing technology 2009, 90, 301.

${ }^{28}$ Baker, E.G. ; Elliott, D.C. Catalytic hydrotreating of biomass-derived oils. In J. Soltes \& T.A. Milne (eds.), Pyrolysis oils from biomass, ACS Symp. Series 376 (Washington, DC: AmericanChemical Society, 1988).

${ }^{29}$ Moffatt, J. M.; Overend, R. P. Direct liquefaction of wood through solvolysis and catalytic hydrodeoxygenation: an engineering assessment, Biomass 1985, 7, 99.

${ }^{30}$ Elliott, D.C.; Sealock, L.J. Jr.; Baker, E.G. Method for the catalytic conversion of organic materials into a product gas. US patent number 5616154, Apr. 17, 1994.

${ }^{31}$ Bouvier, J. M.; Gelus, M.; Maugendre, S. Wood Liquefaction an Overview Applied Energy 1988, 30, 85.

${ }^{32}$ Stevens, D.J. Review and Analysis of the 1980-1989 Biomass Thermochemical Conversion Program. National Renewable Energy Laboratory NREL/TP-421-7501. September 1994.

${ }^{33}$ Solantausta, Y; Beckman, D.; Bridgwater, A.V.; Piebold, J.P.; Elliott, D.C. Assessment of liquefaction and pyrolysis systems. Biomass and Bioenergy 1992, 2, 279. 
${ }^{34}$ Molton, M.P.; Demnitt, T.F.; Donovan, J. M.; Miller, R.K. Mechanism of conversion of cellulosic wastes to liquid fuels in alkaline solution. Conference proceedings: Energy From biomass and wastes, 1978, pp.293.

${ }^{35}$ Osterman, R.D.; Bishop, K.A.; R.F. Rosson. Kinetics of The Thermochemical Conversion OF Cellulose To Oil In Aqueous Alkaline Solution. Conference proceedings: Energy From biomass and wastes $I V, \mathbf{1 9 8 0}$, pp.645.

${ }^{36}$ Eager, R.L.; Mathews, J. F.; Pepper, J. R.; Zohdi, H. Studies on the products resulting form the conversion of aspen poplar to an oil. Can. J. Chem. 1981, 59, 211.

${ }^{37}$ Thigpen, P. L. ; Berry, W. L. Operation of the biomass facility at Albany, OR, Proc. 3rd Annual Biomass Energy Systems Conf., 5-7 June, Golden, Colorado, SERI/TP-33-285, 1979, pp.521.

${ }^{38}$ Berry, W. L. Operations of the biomass facility at Albany, Oregon Wheelabrator Cleanfuel Corporation, July 1, 1978-june 30, 1980, Proc. 3rd Annual Biomass Energy Systems Conf., 5-7 June, Golden, Colorado, SERI/TP-33-285, 1979, pp.105.

${ }^{39}$ Figueroa, C; Ergun, S. Direct liquefaction of biomass - corrective assessment of process development, Proc. 3rd Annual Biomass Energy Systems Conf., 5-7 June 1979, pp.109.

${ }^{40}$ White, D. H.; Wolf, D. Development of an Extruder-feeder Biomass Direct Liquefaction Process, Final Report, PNL-7830, Pacific National laboratory U.S. DOE, Contract DE-AC06-76EL01830, 1991.

${ }^{41}$ White, D. H.; Wolf, D. Direct biomass liquefaction by an extruder-feeder system. Chem. Eng. Comm. 1995, 135, 1.

${ }^{42}$ White, D.H.; Wolf, D Advances in direct biomass liquefaction by the extruder-feeder method. In: Research in Thermochemical Biomass Conversion (edited by Bridgwater, A.V. and Kuester, J.L.), Elsevier Applied Science, 1988, pp.827.

${ }^{43}$ Eager, R.L.; Mathews, J. F.; Pepper, J. R. Liquefaction of Aspen Poplar Wood. Can. J. Chem. Eng., 1982, 60, 289.

${ }^{44}$ Eager, R.L.; Pepper,J.F., Pepper, J.M. A Small Semi-continuous Reactor for the conversion of Wood to Fuel Oil Can. J. Chem. Eng. 1983, 61, 189.

${ }^{45}$ Eager, R.L.; Mathews, J.F.; Pepper, J.M. Liquefaction of aspen poplar to produce oil and chemicals. In Fundamentals in thermochemical biomass conversion (edited by Overend, R.P.; Milne, T .A.; Mudge, L.K.), Springer, 1985; pp. 1051.

${ }^{46}$ Goudriaan, F. - private communication

${ }^{47}$ Matsumura, Y.; Minowa, T.; Potic, B.; Kersten,S.R.A.; Prins, W; Van Swaaij,W.P.M.; Van de Beld, B; Elliott, D.C.; Neuenschwander,G.G.; Kruse, A.; Antal, M.J. Jr. Biomass gasification in near- and super-critical water: Status and prospects. Biomass and Bioenergy 2005, 29, 269.

${ }^{48}$ Fang, Z.; Minowa, T.; Smith, Jr., R. L.; Ogi, T.; Kozinski, J. A. Liquefaction and Gasification of Cellulose with $\mathrm{Na}_{2} \mathrm{CO}_{3}$ and $\mathrm{Ni}$ in Subcritical Water at $350{ }^{\circ} \mathrm{C}$. Ind. Eng. Chem. Res. 2004, 43, 2454.

${ }^{49}$ Elliott, D. C.; Giacoletto, G.M. Bench scale research in biomass liquefaction in support of the Albany, Oregon, experimental facilitiey Proc. 3rd Annual Biomass Energy Systems Conf., 5-7 June, Golden, Colorado, SERI/TP-33-285, 1979, pp. 123. 
${ }^{50}$ Bobleter, O; Bonn, G. The hydrothermolysis of cellobiose and its reaction product D-glucose. Carbohydrate research 1983, 124, 185.

${ }^{51}$ Ogi, T.; Yokoyama, S-Y. Liquid fuel production from woody biomass by direct liquefaction. Sekiyu Gakkaishi 1993, 36, 262.

${ }^{52}$ Luijkx G.C.A. Hydrothermal conversion of carbohydrates and related compounds, $\mathrm{PhD}$ thesis Technical University Delft 1994.

${ }^{53}$ Reynolds, J. G.; Burnham, A. K.; Wallman, P. H. Reactivity of Paper Residues Produced by a Hydrothermal Pretreatment Process for Municipal Solid Wastes. Energy \& Fuels 1997, 11, 98.

${ }^{54}$ Kruse A.; Gawlik, A. Biomass Conversion in Water at 330-410 C and 30-50 MPa. Identification of Key Compounds for Indication of Different Chemical Reaction Pathways. Ind. Eng. Chem. Res. 2003, 42, 267.

${ }^{55}$ Schmieder, H; Abeln, J.; Boukis, N.; Dinjus, E.; Kruse, A.; Kluth, M.; Petrich, G.; Sadri, E.; Schacht M. Hydrothermal gasification of biomass and organic wastes. Journal of Supercritical Fluids 2000, 17, 145.

${ }^{56}$ Williams, P. T.; Onwudili, J. Subcritical and Supercritical Water Gasification of Cellulose, Starch, Glucose, and Biomass Waste. Energy \& Fuels 2006, 20, 1259.

${ }^{57}$ Waldner, M. H.; Vogel, F. Renewable production of methane from woody biomass by catalytic hydrothermal gasification. Ind. Eng. Chem. Res. 2005, 44, 4543.

${ }^{58}$ Matsumura,Y.; Yanachi, S.; Yoshida, T. Glucose Decomposition Kinetics in Water at 25 MPa in the Temperature Range of 448-673 K. Ind. Eng. Chem. Res. 2006, 45, 1875.

${ }^{59}$ Itoh, S.; Suzuki, A.; Nakamura, T.; Yokoyama, S-Y. Production of heavy oil from sewage sludge by direct thermochemical liquefaction. Desalination, 1994, 98, 127.

${ }^{60} \mathrm{http}: / /$ www.ewire.com/display.cfm/Wire_ID/619 visited on 02.05.2009.

${ }^{61}$ http://edgar.brand.edgaronline.com/EFX_dll/EDGARpro.dll?FetchFilingHTML1?ID=2866522\&SessionID=KEUxWjnBP1 cZjs7\#G88141E10KSB_HTM_TOC visited on 02.05.2009.

${ }^{62}$ Fassbender, A.G. Sewage treatment system, US patent number 6893566, May 17, 2005.

${ }^{63}$ http://www.enertech.com/about/downloads.html visited on 02.05.2009.

${ }^{64}$ Baker, E. G.; Sealock, L. J., Jr.; Butner, R. S.; Elliott, D. C.; Neuenschwander, G. G.; Banns, N. G. Catalytic Destruction of Hazardous Organics in Aqueous Wastes: Continuous Reactor System Experiments. Hazard. Waste Hazard. Mater. 1989, 6, 87.

${ }^{65}$ Elliott, D.C.; Sealock, L. J. -Jr.; Baker E. G. Chemical Processing in High-pressure Aqueous Environments. 2. Development of Catalysts for Gasification. Ind. Eng. Chem. Res. 1993, 32, 199.

${ }^{66}$ Elliott,D.C.; Hart, T.R.; Neuenschwander, G.G. Chemical Processing in High-Pressure Aqueous Environments. 8. Improved Catalysts for Hydrothermal Gasification Ind. Eng. Chem. Res. 2006, 45, 3776.

${ }^{67}$ Sealock, L. J. -Jr.; Elliott, D.C.; Baker E. G. Fassbender, A. G.; Silva, L.J. Chemical Processing in High-Pressure Aqueous Environments. 5. New Processing Concepts. Ind. Eng. Chem. Res. 1996, 35,4111 
${ }^{68} \mathrm{http}: / /$ ergosphere.files.wordpress.com/2007/04/cwt_genconflasvegas3_3_04.pdf visited on 02.05.2009

${ }^{69}$ http://www.carthagepress.com/news/x1092978749/Plant-closing-mixed-blessing-for-Carthage visited on 02.05.2009.

${ }^{70}$ Mason, W.H. Apraratus for and process of explosion fibration of lignocellulose material. US patent number 1,655,618, Jan. 10. 1928.

${ }^{71}$ Lipinsky, E.S. Pretreatment of biomass for thermochemical biomass conversion. In: Fundamentals of Thermochemical Biomass Conversion (edited by Overend, R.P.; Milne, T .A.; Mudge, L.K.), Elsevier Applied Science, 1985, pp.77.

${ }^{72}$ Chornet, E.; Vanasse, C.; Lemonnier, J.P.; Overend, R.P. Preparation and processing of medium and high consistency biomass suspensions. In: Research in Thermochemical Biomass Conversion (edited by Bridgwater, A.V. and Kuester, J.L.), Elsevier Applied Science, 1988, pp.766.

${ }^{73}$ Vanesse, C.; Lemonnier, J.P.; Eugène, D.; Chornet, E.; Overend, R.P. Pretreatment of wood flour slurries prior to liquefaction. Can. J.Chem. Eng. 1988, 66, 107.

${ }^{74}$ McMillan, J.D. Processes for Pretreating Lignocellulosic Biomass - A Review. NREL report: NREL/TP-421-4978. November 1992.

${ }^{75}$ Mosier, N.; Wyman, C.; Dale, B.; Elander, R.; Lee, Y.Y.; Holtzapple, M.; Ladisch, M. Features of promising technologies for pretreatment of lignocellulosic biomass. Bioresource Technology 2005, 96, 673.

${ }^{76}$ Savage, Ph. E.; Gopalan, S.; Mizan, T.I.; Martino, C. J.; Brock, Eric E. Reactions at supercritical conditions: Applications and fundamentals AIChE Journal 2004, 41, 1723.

${ }^{77}$ Akiya, N.; Savage, P. E.; Roles of Water for Chemical Reactions in High- Temperature Water. Chem. Rev. 2002, 102, 2725.

${ }^{78}$ Katritzky, A.R.; Nichols, D.A.; Siskin, M.; Murugan, R.; Balasubramanian ,M. Reactions in HighTemperature Aqueous Media"Chem. Rev. 2001, 101, 837.

${ }^{79}$ Buhler, W.; Dinjus, E.; Ederer, H.J.; Kruse, A. Ionic Reactions and Pyrolysis Of Glycerol As Competiting Reaction Pathways in Near- and Supercritical water. J. of Supercritical Fluids 2002, 22, 37.

${ }^{80}$ Garrote, G.; Dominguez, H., Parajo, J.C. Hydrothermal processing of lignocellulosic materials Holz als Roh- und Werkstoff, 1999, 57, 191.

${ }^{81}$ Lin SY. Production of water-soluble polycarboxylic lignin by an oxygen-alkali process. US Patent 3910873, 1975.

${ }^{82}$ Fang, Z.; Fang, C. Complete Dissolution and Hydrolysis of Wood in Hot Water, AIChE Journal, 2008, 54, 2751.

${ }^{83}$ Minowa, T.; Ogi, T.; Dote, Y.; Yokoyama, S-Y. Effect of Lignin Content on Direct Liquefaction of Bark. International Chemical Engineering, 1994, 34, 428.

${ }^{84}$ Demirbas A. Effect of lignin content on aqueous liquefaction products of biomass. Energy Conversion \& Management, 2000, 41, 1601. 
${ }^{85}$ Amin, S.; Reid, R. C.; Modell, M. Reforming and Decomposition of Glucose in an Aqueous Phase. Intersociety Conference on Environmental Systems, San Francisco, CA, 1975; The American Society of Mechanical Engineers (ASME): New York, 1975; ASME Paper No. 75-ENAs-21.

${ }^{86}$ Kritzer, P. Corrosion in high-temperature and supercritical water and aqueous solutions: a review. Journal of Supercritical Fluids 2004, 29, 1.

${ }^{87}$ Yokoyama, S-Y.; Suzuki, A.; Murakami, M.; Ogi, T.; Koguchi, K.; Nakamura, E. Liquid fuel production from sewage sludge by catalytic conversion using sodium carbonate. Fuel, 1987, 66, 1150 .

${ }^{88}$ Srokol, Z.W. Reaction Pathways During Hydrothermal Upgrading of Biomass, PhD thesis TU Delft, 2009. 


\title{
CHAPTER 2
}

\section{High-Throughput Screening Technique for Conversion in Hot Compressed Water: Quantification and Characterization of Liquid and Solid Products}

\begin{abstract}
A high-throughput screening technique, developed earlier ${ }^{l}$ for reaction systems with primarily gaseous products, has been extended with quantitative and qualitative analysis of condensed reaction products. The technique is based on catalytically inert quartz capillaries $(2 \mathrm{~mm}$ internal diameter) as micro reactors, which allows for cheap and safe experimentation. To validate the technique, hydrothermal conversion (HTC) $\left(T \sim 350{ }^{\circ} \mathrm{C}, p \sim 200\right.$ bar) of beech wood and model compounds was used. Separation and sample preparation methods have been developed to recover the condensed reaction products. These methods, combined with the chemical analysis techniques, have shown to be accurate with respect to product recovery and detecting trends in the yield and composition of the products as a function of the operating conditions.
\end{abstract}




\section{Introduction}

Earlier in our group a batch high-throughput technique for screening the operating window of biomass conversion in hot compressed water has been introduced. ${ }^{1}$ The technique is based on quartz capillaries ( $1 \mathrm{~mm}$ internal diameter) as micro reactors and allows quick, safe, and cheap experimentation under extreme temperatures (up to $900{ }^{\circ} \mathrm{C}$ ) and pressures (up to 600 bar). Experimental investigation of such systems is normally difficult and expensive, because the high temperatures and pressures involved lead to high equipment costs, time-consuming tests, and extensive safety precautions. For reaction systems with only or mainly gaseous products (viz. gasification, reforming, and methanation), it has been shown that the capillary technique provides sufficient accuracy for mapping of the operating window, trend detection, and determination of reaction rate data. ${ }^{1,2}$ However, conversion of biomass in hot compressed water leads also to liquid and solid products. In fact, in the hydrothermal liquefaction process, these condensed phases are the main products. ${ }^{3-5}$

The reported operating temperatures for hydrothermal conversion (HTC) are in the range of 250-374 ${ }^{\circ} \mathrm{C}$ with pressures kept above the corresponding vapor pressure of water at the given temperature. ${ }^{4,5}$ Under these conditions, biomass is converted, in a complex sequence of chemical reactions, into various compounds, which, upon cooling the reactor effluent, constitute three different phases: a water phase, a hydrophobic phase, and a gas phase. By extraction, the hydrophobic reaction products can be further separated into a solvent (e.g., acetone) soluble and a solvent insoluble part. Normally, the hydrophobic phase is considered to be the main reaction product and has considerably lower oxygen content (typically 20 vs. $45 \mathrm{wt} \%$ ) and a lower heating value (typically $30 \mathrm{vs.} 17 \mathrm{MJ} / \mathrm{kg}$ ) than the feedstock. The whole hydrophobic product can be used as fuel in furnaces and boilers, ${ }^{4,5}$ and the solvent soluble fraction can be upgraded into transportation fuel by means of, e.g., catalytic deoxygenation. ${ }^{4}$

This chapter deals with improving the capillary technique for application with the reaction systems that have gaseous, liquid, and solid products. The chapter describes the developed separation methods, as well as, the applied analytical technique used to characterize the recovered reaction products. Results of HTC experiments (beech wood and model compounds) are presented to show the mass balance closure and reproducibility that can be obtained with the technique. Next to that, examples of the method's potential for following the feedstock's conversion and the composition of the products as functions of the process conditions are presented. In the following chapters (including additional data), HTC of biomass will be discussed from a chemical and process point of view.

Previously described experimental methods for studying the reaction pathways and kinetics of biomass conversion in subcritical water used much diluted solutions as 
feedstocks (less than $1 \mathrm{wt} \%$ organics in water) $)^{6-8}$ This simplifies the experiments and allows for in-situ measurements. However, the applied conditions are far from those expected for industrial processes ${ }^{3-5}$ in which, for economic reasons, the concentration of the feedstock should be much higher. Moreover, the product distribution is affected by the concentration of the feedstock. ${ }^{4,-11}$ In the present study, water solutions and slurries of ca. $9 \mathrm{wt} \%$ organics have been used in order to get closer to the industrial conditions. ${ }^{3-5,12}$

\section{Experimental}

\section{Definition of Products}

In the previously reported literature on HTC, it is not always clear how exactly the lumped product classes such as gas, oil ${ }^{13-16}$ and biocrude ${ }^{4-6}$ are defined. In the present contribution, condensed products are lumped according to their solubility in water and an organic solvent. Acetone and non-stabilized tetrahydrofuran (THF) were used. Acetone is a good and stable solvent, which is used by many researchers to classify the HTC reaction products ${ }^{14,17,18}$ On some samples, gel permeation chromatography has been performed with THF as the mobile phase. Accordingly, THF was used as the solvent in the product recovery procedures. The gaseous products include those gases that have a normal boiling point lower than $250 \mathrm{~K}$.

As previously mentioned, two different condensed products are present upon cooling of the reactor effluent, namely, a water phase and a hydrophobic phase. Organics present in the water phase will be referred to as water soluble (WS) organics. The hydrophobic organic products that are soluble in the solvent are referred to as solvent soluble (SS) organics. WS and SS products are often liquids at room temperature. In one of the separation methods used (see section: Separation Method 1), the whole reactor effluent is washed with an excess of acetone. Because the water soluble organics also completely dissolve in an excess of acetone, a combined phase is created when applying separation method 1 that contains both the water soluble organics and the acetone soluble fraction of the hydrophobic phase.

The organics in this phase are called the water-solvent soluble (WSS) organics. In separation method 2, the water soluble organics are removed from the reaction mixture (see section: Separation Method 2) before the addition of the solvent. This allowed two streams of products (WS and SS) to can be collected and analyzed separately.

Components in the hydrophobic phase that are under ambient conditions insoluble in both water and a solvent are called water-solvent insoluble (WSIS) organics. These WSIS organics, once separated, form a solid product at room temperature. This product 
fraction is sometimes referred to as coke $\mathrm{or}^{9}$ char. ${ }^{14}$ However, this is not equivalent to the coke found in cracking and reforming processes or to the char from gasification and pyrolysis. WSIS organics contain considerable amounts of oxygen and hydrogen and are in fact, in terms of elemental composition, similar to the solvent soluble compounds. ${ }^{19}$

\section{Quartz Capillary Reactors}

In our experimental method, quartz capillaries of $2 \mathrm{~mm}$ i.d., $4 \mathrm{~mm}$ o.d., and ca. $150 \mathrm{~mm}$ in length (volume $\sim 0.5 \mathrm{~mL}$ ) were used as batch micro reactors. Solutions of model compounds in water were used as feedstocks. For example, glucose solutions (5-10 wt $\%$ ) were charged into the capillaries in the amount required to achieve approximately 9 wt $\%$ of glucose in liquid water at the reaction temperature (an equilibrium amount of water evaporates at the reaction temperature). Using a syringe, $100-150 \mathrm{mg}$ of such a solution, which corresponded to 20 to $30 \%$ of the total length of a capillary (at $20{ }^{\circ} \mathrm{C}$ ), was charged into a capillary. Next to model compound solutions, dried beech sawdust suspended in water (ca. $9 \mathrm{wt} \%$ at the reaction temperature) was also used (elemental composition beech wood on a dry and ash-free basis: $\mathrm{C}=46.23 \mathrm{wt} \%, \mathrm{H}=5.66 \mathrm{wt} \%$, $\mathrm{O}=48.11 \mathrm{wt} \%$, ash content $=$ ca. $1.3 \mathrm{wt} \%$, particle diameter $=0.1-0.5 \mathrm{~mm}$ ). Air from the gas cap above the solution was replaced with nitrogen, by placing a long needle just above the liquid level, through which a nitrogen flow was directed. A hydrogen flame was used to melt the capillaries, thus sealing them. The melting procedure was fast enough (within $10 \mathrm{~s}$ ) to avoid increasing of the temperature of the liquid inside the capillary (which is located $10 \mathrm{~cm}$ from the sealed side), thus preventing vapor loss.

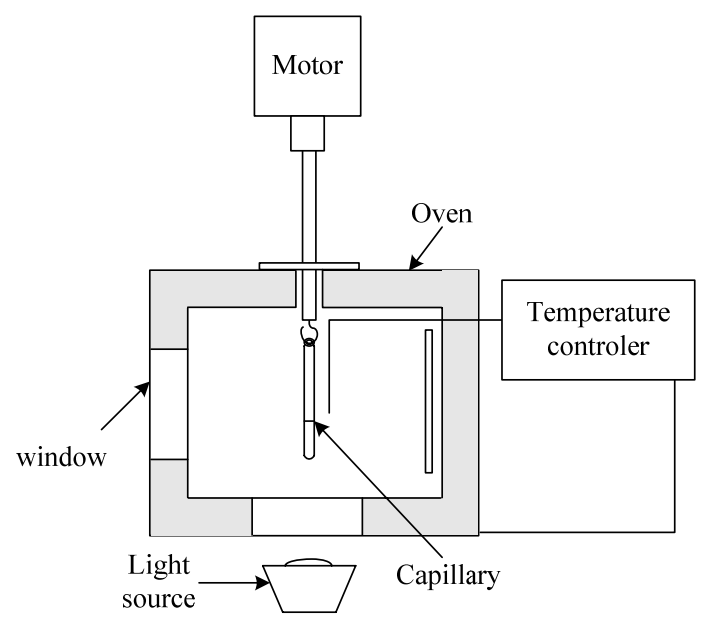

Figure 1. Schematic presentation of the capillary setup with the hot air oven. 
Figure 1 is a schematic representation of the capillary setup with a hot air oven, which was used in most of the experiments. The oven was equipped with a loophole and an artificial light source to allow visualization of the quartz capillary and its content. The capillaries were attached to a pneumatic piston and vibrated. This improved the mixing and ensured a good distribution of catalyst (if used) over the capillary.

If very short heating times were required and if visual observation was not intended, a heated fluidized sand bed was used. The time required for heating the capillary to the temperature of the oven / fluid bed was ca. $175 \mathrm{~s}$ in the hot air oven, and only ca. $20 \mathrm{~s}$ in the fluidized sand bed (see Figure 2). The procedure for observing the heating trajectory from measurements inside the capillaries in separate experiments has been described by Potic et al. ${ }^{1}$ In the results presented in this chapter, the heating time $\left(\tau_{h}\right)$ is discussed separately from the reaction time $\left(\tau_{r}\right)$. The reaction time was defined as the time between the temperature inside the capillary reaching $95 \%$ of the oven temperature and quenching. Accordingly, the heating time $\left(\tau_{h}\right)$ was defined as the time span from inserting the capillary into the heated environment until the temperature inside the capillary reached $95 \%$ of the oven / fluid bed temperature (hot air oven: $\tau_{h}=120 \mathrm{~s}$, fluid bed heater: $\tau_{h}=12 \mathrm{~s}$ ).

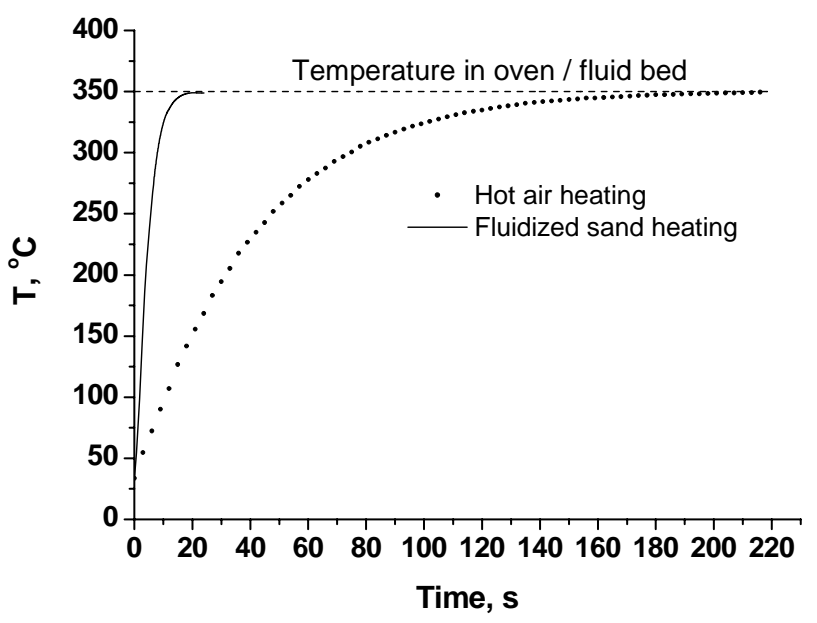

Figure 2. Measured temperature trajectories inside the quartz capillaries.

Because diluted solutions and mixtures of ca. 9 wt \% biomass were used, the pressure inside the capillary at the reaction temperature was estimated by assuming that it was only generated by water vapor. If a more precise estimate of the pressure is required, 
thermodynamic calculations can be applied on basis of the initial amount of water present in the capillary and the measured amount of product gases.

After a certain time at the oven temperature, the capillaries were quenched in cold water, which ensured cessation of all reactions. After cooling, the reaction products were still dispersed over the capillary. For determination of the gaseous products, capillaries were crushed with a hammer-like mechanism in a special gas collection / analysis chamber (see Potic et al. ${ }^{1}$ and section: Product analysis). In the procedure for liquid and solid analysis, capillaries were shaken to ensure that the condensed products are well separated from the produced gases. Subsequently, the capillaries were frozen in liquid nitrogen in order to minimize the loss of condensed products through entrainment with quickly evolving gases during the opening. A scratch was made on the gas phase side to allow opening of the capillaries. Opening was performed with caution, since the pressure inside the capillaries was elevated due to the presence of gaseous reaction products. After opening, the capillaries were allowed to slowly reach room temperature and gradual gas evolution was promoted by stirring the content of the capillaries using a steel wire. After this point, depending on the aim of the experiment, one of two procedures took place. The separation methods are described in detail below.

\section{Separation Method 1}

This procedure involves separation of the condensed products into the WSS and the WSIS phase.

The following procedure was applied to collect the WSS fraction from one capillary. Approximately $150 \mu \mathrm{l}$ of acetone was added into the capillary and a stainless steel wire was used to stir the content of the capillary causing grinding of the solid reaction product. After that, another $10 \mu \mathrm{l}$ of acetone was added while the stainless steel wire was carefully removed. A PTFE thread seal tape was wrapped around the open end of the capillary, which was then placed on a filtration assembly in a vertical position (see Figure 3).

The filtration section consisted of a stainless steel micro filter retainer (Whatman/Schleicher \& Schüll, Dassel, Germany) containing an exchangeable, acetone washed, dried and weighed glass fiber filter (diameter: $13 \mathrm{~mm}$, thickness: $3 \mathrm{~mm}$, mass: approx. $10 \mathrm{mg}$, particles retained in liquid $\mathrm{d}_{\mathrm{p}}<1.6 \mu \mathrm{m}$, Whatman / Schleicher \& Schüll, Dassel, Germany) and a vacuum filtration chamber "VACMASTER-10 manifold" (Separtis $\mathrm{GmbH}$, Grenzach-Wyhlen, Germany) containing a cleaned, dried, weighed flask (volume $=10 \mathrm{ml}$ ) to collect the WSS products. Filtration was facilitated by the use of vacuum (ca. 500 mbar), adjusted by a fine vacuum control and safety valve at room temperature. 


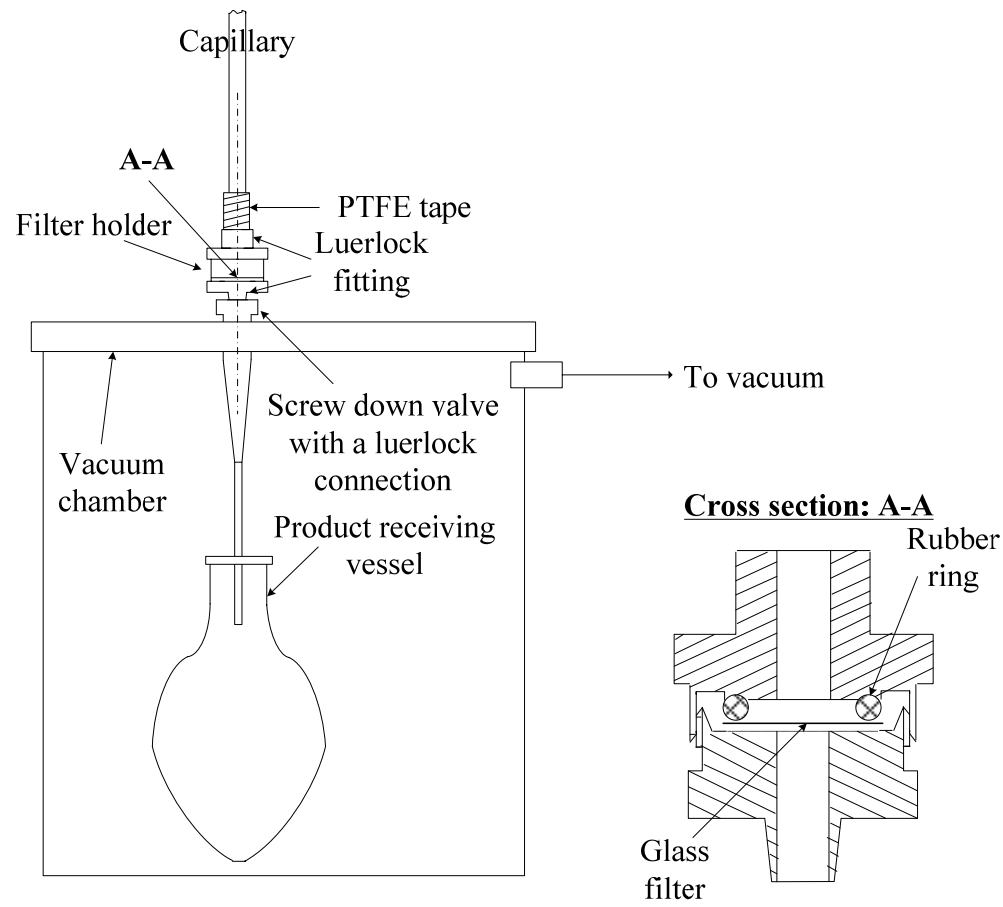

Figure 3. Schematic presentation of the filter assembly.

When the WSS phase was separated from the WSIS phase, the vacuum was slowly relieved. The capillary was subsequently washed 5 times with $200 \mu \mathrm{l}$ acetone and the effluent was collected and mixed with the WSS product in the flask. The solvent (acetone) was removed by vacuum evaporation at $40{ }^{\circ} \mathrm{C}$ and ca. $450 \mathrm{mbar}$ to $350 \mathrm{mbar}$ in a rotating vacuum evaporator. Prior to weighing and elemental analysis, the WSS samples were dried and stored in an exsiccator over phosphorus pentoxide for 14 days at room temperature.

The WSIS material was collected on the separate filters (described above), which were subsequently dried at $105{ }^{\circ} \mathrm{C}$ for $12 \mathrm{~h}$, cooled to room temperature in an exsiccator over activated silica gel and stored until analysis.

\section{Separation Method 2}

This method involves separate collection of WS and SS phase. After opening, the water phase, containing WS products was separated by centrifugation, removed from the capillary using a long-needled syringe (volume: $500 \mu 1$, Hamilton and collected separately. Subsequently, $150 \mu \mathrm{l}$ of water (purest grade) and $150 \mu \mathrm{l}$ of tetrahydrofuran (THF) were 
added to the capillary. A stainless steel wire was used to facilitate the mixing. The SS fraction was removed from the capillary using a syringe and collected in a tapered flask (volume: $10 \mathrm{ml}$ ). After that, $10 \mu \mathrm{l}$ of THF was added and the wire was carefully removed. The capillary was centrifuged to separate the solvent soluble and insoluble phases. The SS phase was removed with a syringe and collected in a tapered flask. The washing and centrifugation step was repeated until the solvent phase was colorless. All SS fractions were added to the same flask. The THF was removed by rotation evaporation. The SS product was dried over phosphorus pentoxide for 14 days.

\section{Product Analysis}

\section{$\underline{\text { Gas Analysis }}$}

The gaseous products were qualitatively and quantitatively analyzed using the method described by Potic et al. ${ }^{1}$ Gas products were released in a metal sampling chamber $(50 \mathrm{ml})$ by smashing the capillary with a hammer-like mechanism. The gas phase inside the capillary was analyzed with respect to the absolute amount and the composition. On the basis of the readings of a GC, the total number of moles present in the sampling chamber and the amount of feedstock, the mass balance (yields and conversion) was calculated.

\section{Elemental Analysis of Condensed Phases}

For the analysis of the WSS and the SS products, the dried products of five capillaries (15 $30 \mathrm{mg}$ ) were combined.

The elemental analysis was performed using a Flash EA 1112 (ThermoQuest, Rodano, Italy) elemental analyzer, calibrated by five point calibration with acetanilide and a mixture of acetanilide and titanium oxide (in 1 to 2 ratio) as external standards ( 0.500 up to $3.000 \mathrm{mg}$ used in each analysis). After combustion of the sample in pure oxygen, and catalytic transformation of the combustion products into stable non-reactive gases (using copper for $\mathrm{N}_{2}$ and vanadium pentoxide for $\mathrm{H}_{2} \mathrm{O}$ and $\mathrm{CO}_{2}$ ), the peak areas of $\mathrm{N}_{2}, \mathrm{CO}_{2}$ and $\mathrm{H}_{2} \mathrm{O}$ were determined by gas chromatography (mobile phase: helium) with a thermal conductivity detector (GC/TCD). The oxygen amount was calculated by difference (mass of organics in recovered product - mass of $\mathrm{C}$ in product - mass of $\mathrm{H}$ in product - mass of $\mathrm{N}$ in product). The samples were analyzed in duplicate.

For the elemental analysis of WSIS product, the total dried WSIS sample along with the filter was placed in a small tin-foil container (15 mm x $15 \mathrm{~mm}$, approx. $140 \mathrm{mg}$ ). The open end of the foil was closed carefully by using two pairs of tweezers taking special care not to lose any material. The filters used were carbon and hydrogen free, which was verified by the analysis of the acetone washed, dried, blank filters. Approximately $2 \mathrm{mg}$ of vanadium pentoxide was added to each sample to ensure its complete combustion. The elemental 
analyses were performed according to the same procedure as with the WSS and SS samples.

Gas Chromatography with Mass Selective Detection and Gas Chromatography with Flame Ionization Detection

GC/MS and GC/FID were used to identify and quantify discrete compounds in the WS, SS and WSS products. By applying this technique, it is possible to determine the extent of conversion realized (in the case of carbohydrate monomers like glucose) and to study the changes in the composition of the products as a function of the operating conditions. To detect and quantify glucose and other carbohydrate monomers by gas chromatography, these compounds were transformed by acetylation of their hydroxyl groups. The detection of the acetylated carbohydrates was performed by gas chromatography with mass selective detection (GC/MS). This method allows differentiation between carbohydrate compounds of very similar structures and very similar mass spectra, such as, for example: polyhydroxyaldehyde, hemiacetal and acetal. The quantification of the identified compounds was accomplished by gas chromatography with flame ionization detection (GC/FID). The measurement procedure is described in detail below. A sample of $10.000 \mathrm{mg}$ of the wateracetone soluble phase as well as 0.500 and $1.00 \mathrm{mg}$ reference standard compounds [e.g. glucose, 1,6-anhydro- $\beta$-D-glucopyranose (levoglucosan),1,6-anhydro- $\beta$-D-mannopyranose, galactosan, levoglucosenone] were weighed in a $7 \mathrm{ml}$ flask with a solvent inert screw cap. Then $5 \mathrm{ml}$ of water-free pyridine was added to each flask. Each flask was closed and the samples were completely dissolved in pyridine at room temperature, by shaking the flask.

Exactly $0.500 \mathrm{ml}$ of water-free acetic anhydride, exactly $0.100 \mathrm{ml}$ of the internal standard solution $(2.0073 \mathrm{mg}$ fluoranthene per $\mathrm{ml}$ acetone; ISTD) and $0.500 \mathrm{ml}$ of the pyridine solution were added to a gas chromatography vial (volume: $1.5 \mathrm{ml}$ ). The vial was hermetically sealed, using a cap with a solvent inert septum, and homogenized by shaking. The vials were placed in a sand bath at $105^{\circ} \mathrm{C}$ and allowed to stand for 20 min to promote the pyridine catalyzed acetylating reaction of hydroxyl groups.

The samples and standard solutions were analyzed by a gas chromatograph (Hewlett Packard HP6890) equipped with a mass selective detector (MSD, Hewlett Packard HP5972) and a flame ionization detector (FID). The separation was performed on a column ZEBRON ZB1701 (length: $60 \mathrm{~m}$, inner diameter: $0.25 \mathrm{~mm}$, film thickness: $0.25 \mu \mathrm{m}, 14 \%$ -cyanopropyl-phenyl-86\% -dimethyl-siloxane co-polymer). A temperature program was used with initial temperature: $100{ }^{\circ} \mathrm{C}$, hold time: $2 \mathrm{~min}$; ramp $1: 1.5^{\circ} \mathrm{C} / \mathrm{min}$ up to $200{ }^{\circ} \mathrm{C}$; ramp 2: $3{ }^{\circ} \mathrm{C} / \mathrm{min}$ up to $260{ }^{\circ} \mathrm{C}$; ramp 3: $10^{\circ} \mathrm{C} / \mathrm{min}$ up to $290{ }^{\circ} \mathrm{C}$, hold time: $30 \mathrm{~min}$. The injector temperature was set to $250^{\circ} \mathrm{C}$. The temperature of the FID was set to $280{ }^{\circ} \mathrm{C}$. The flow rate was $2.3 \mathrm{ml} / \mathrm{min}$. The Split-Flow ratio was $5: 1$. Helium gas stream on the column was split into a stream for MSD (and a stream for FID detection. The solvent delay was $5.5 \mathrm{~min}$. The detection of mass fragments began after $5.5 \mathrm{~min}$ (time window 5.5 up to 
$70 \mathrm{~min}$ ) for molecule fragments with a mass charge ratio $(\mathrm{m} / \mathrm{z})$ of 33 up to 550 . After 70 min, molecule fragments with $(\mathrm{m} / \mathrm{z})$ of 33 up to 700 were detected. The temperature of the ion source was set to $140{ }^{\circ} \mathrm{C}$. The ionization energy for MSD was set to $70 \mathrm{eV}$. The samples $(1 \mu \mathrm{l})$ were injected by an auto sampler system (CTC Analytics, multi functional auto sampler Combi PAL). For analysis of the spectra, ChemStation software (G1701DA MSD) was used. The compounds were identified by utilization of the NIST mass spectral search program (version 2.0a 2002) and additionally compared to mass spectra of the known acetylated standard reference compounds of glucose, 1,6-anhydro- $\beta$-Dglucopyronose, 1.6-anhydro- $\beta$-D-mannopypyronase and galactosan. The retention times of the acetylated standard reference compounds and relative retention time were compared to the internal standard.

\section{Safety Issues}

The volume of the used capillary is very small $(0.5 \mathrm{ml})$. This limits the maximal amount of gases realized by an explosion to ca. $5 \mathrm{ml}$ so that there is no danger of toxic product gases. Explosions were sometimes witnessed in the oven, while quenching, and in the manual transfer from the oven to the quench bath. For protection against the impact of quartz splinters, the operators wore gloves and full facial/neck protection screens. The capillaries were sealed by trained glass workshop personnel.

\section{Conversion, Yields and Carbon Balance}

The amount of unconverted glucose in the WSS phase was measured as described above. The glucose conversion was calculated as follows:

$$
X_{g l u \cos e}=\frac{m_{g l u \operatorname{cose} \text { in feed }}-m_{g l u \text { cose in WSS }}}{m_{\text {glucose in feed }}}
$$

The conversion of beech wood was assumed to be 1 . This is a reasonable assumption considering the residence times used. Due to the absence of heat transfer limitations, resulting in spatially uniform heating of the small particles, each individual polymer (hemicellulose, cellulose, lignin) is likely to undergo a reaction under the applied HTC conditions $\left(\mathrm{T}=350^{\circ} \mathrm{C}, 10\right.$ min reaction time).

Yields and carbon yields were defined on dry basis and, in case of beech wood, dry and ash free basis of the feedstock material. The amount of WSS organics was measured by 
weighing the recovered samples after drying. In the cases when glucose was used as feedstock, the yield of WSS product was calculated by:

$$
Y_{W S S}=\frac{m_{W S S}-m_{g l u \operatorname{cose} \text { in } W S S}}{m_{\text {glucose in feed }}}
$$

For beech wood the yield of WSS product was calculated by:

$$
Y_{W S S}=\frac{m_{W S S}}{m_{f e e d, D A F}}
$$

The gas yield was calculated as follows:

$$
Y_{\text {gas }}=\frac{m_{\mathrm{CO}_{2}}+m_{\mathrm{CO}}+m_{\mathrm{CH}_{4}}+m_{\mathrm{H}_{2}}}{m_{\text {feed }, \mathrm{DAF}}}
$$

The carbon yield is used to evaluate the mass balance closure of the new technique, because only carbon in the products can be related unequivocally to the organic feedstock. Hydrogen and oxygen in the products can stem from the organic feed, as well as, from water.

The carbon yields of the reaction products were directly obtained from the analysis:

$$
\begin{aligned}
& Y_{W S S}^{C}=\frac{m_{W S S}^{C}}{m_{\text {feed }}^{C}} \\
& Y_{\text {gas }}^{C}=\frac{m_{\mathrm{CO}_{2}}^{C}+m_{\mathrm{CO}}^{C}+m_{\mathrm{CH}_{4}}^{C}}{m_{\text {feed }}^{C}} \\
& Y_{W S I S}^{C}=\frac{m_{W S I S}^{C}}{m_{\text {feed }}^{C}}
\end{aligned}
$$

When glucose solutions were used as feedstock, the carbon yield of unconverted feedstock was calculated:

$$
Y_{\text {unconverted glucose }}^{C}=\frac{m_{g l u \cos e \text { in WSS }}^{C}}{m_{f e e d}^{C}}
$$




\section{Results and discussion}

\section{Discussion on the Developed Separation Methods}

Separation method 2 suffered from a poor product recovery and very cumbersome product handling. Nevertheless, separation method 2 remains useful as it can be applied in addition to separation method 1 to determine the composition of the SS and the WSS products individually. Separation method 1 combines the WS and SS organics. By applying this method the elemental composition of the WSS, the WSIS and the gaseous phases can be determined, resulting in an overall carbon balance, as well as, the absolute yields of the gases and WSS organics. Separation method 1 was developed primarily to improve and to simplify the collection of the products from the capillary. Combining the WS and the SS fraction of the hydrophobic product may be considered a drawback of the technique, but it is actually a benefit, because the distribution of these compounds over the hydrophilic and hydrophobic products is arbitrary. The distribution will depend on the feedstock's moisture content and the layout of the actual process. For example, if the water phase is recycled in a continuous process, the amount of organics passing to the water phase is expected to decrease in favor of the SS fraction of the hydrophobic phase, compared to the once through water flow case. Combining the WS and the SS products, as performed in separation method 1, provides direct information on the total amount of organics in all the liquid phases in the HTC process.

\section{Limitations of the Technique}

A current limitation of the technique is the inability of measuring the absolute amount of the WSIS product due to the presence of glass splinters generated during the opening procedure. This means that the oxygen content of WSIS remains unknown because it is calculated by difference. This problem could be overcome by using a CHNS and O analyzer configured for direct oxygen determination. This equipment was, however, not available for this study.

Carrying out the actual tests with the capillaries and analysis of the product gases is a fast process; 20 to 30 experiments can be performed in one day. However, the separation methods and the sample preparations required for quantification and qualification of the condensed phases require longer time due to extensive drying periods. As a result, there is an approximate 2 weeks delay between the capillary tests combined with the gas product analysis and the results of the liquid and solid analysis. 
Obviously, a non-invasive technique that detects and quantifies the condensed products through the walls of the capillary would be much faster. In fact, such a technique has been developed and is used for studies investigating kinetics and reaction pathways of HTC of model compounds. ${ }^{21}$ However, these studies typically use highly diluted solutions $(<1 \mathrm{wt}$ $\%$ organics) as feedstock. This results in a single phase clear reaction effluent. More concentrated feeds were used in this present investigation, with the aim of simulating industrially important conditions, resulting in a multi-phase reaction medium with carbonaceous deposits making on-line non-invasive detection much more difficult.

One obvious limitation of the present capillary technique is that only liquid and solid feedstock materials can be used. It is impossible to charge the capillaries accurately with known amount of gas, without losing or burning some of it during sealing.

\section{Mass Balance and Reproducibility}

Potic at al. ${ }^{1}$ were able to recover gaseous products well utilizing the capillary technique. This evaluation was based on the gas recovery during gasification experiments with diluted formic acid at temperatures above $650{ }^{\circ} \mathrm{C}$ for which the conversion to gases is known to be complete $^{22}$. In present investigation, these experiments have been repeated; again with excellent mass balance closure (carbon yield of the gas phase products was calculated to be between 0.97 and 1.02 after the gasification in supercritical water at $700{ }^{\circ} \mathrm{C}$ or more for at least 5 min reaction time).

To evaluate the separation methods, specially prepared model mixtures were used to investigate the recovery of the condensed products. These mixtures were created from 2,6ditertbutyl-4-methylphenol (model compound for WSS ), polypropylene (model compound for WSIS) and water. Several capillaries were charged with different amounts of these components, before they were sealed. The amounts of the components were chosen in such a way that they were in the range of the expected yields of liquefaction experiments with real feedstock materials. Separation method 1 was applied and the elemental analysis was performed on the obtained product phases. 

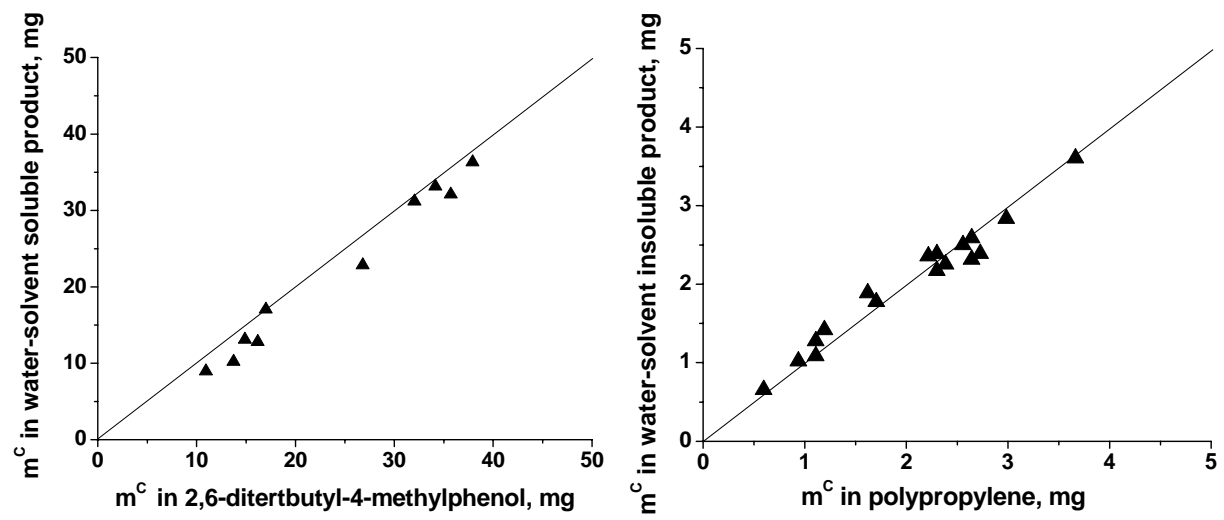

Figure 4. Parity plots showing the amount of carbon recovered in the condensed products versus the amount of carbon in the model compounds.

In Figure 4, the amount of carbon obtained from the elemental analysis of the WSS and WSIS phases are compared with the amount of carbon that was actually put into the capillary via 2,6-ditertbutyl-4-methylphenol and polypropylene respectively. From Figure 4 it can be concluded that the recovery of the WSIS organics is very good. The recovery of the WSS organics is also fairly good. However, systematically less carbon was retrieved than was placed inside the capillary. This is ascribed to the loss of 2,6-ditertbutyl-4methylphenol during acetone evaporation.

In Table 1, the results of HTC experiments of $9 \mathrm{wt} \%$ glucose solutions at the oven temperature of $350^{\circ} \mathrm{C}$ (hot air oven) are presented.

In these experiments between $78 \%$ and $97 \%$ of the carbon in the glucose has been recovered as gaseous, WSS and WSIS products $\left(Y^{C}=0.78-0.97\right)$.

Table 2 lists the results of experiments with a water and beech sawdust mixture at $350{ }^{\circ} \mathrm{C}$ and $8 \mathrm{~min}$ reaction time. In two of these experiments a catalyst has been used: $2 \mathrm{wt} \% \mathrm{Ru}$ on $\mathrm{TiO}_{2}$ (Degussa), active surface $=40-50 \mathrm{~m}^{2} / \mathrm{g}$, bulk density $=0.9-1 \mathrm{~kg} / \mathrm{l}$, pellets were crushed to obtain the particle size of 100-250 $\mu \mathrm{m}$. The carbon yield in the beech wood experiments $\left(Y^{C}\right)$ is 0.78 to 1.07 . The carbon balance closures determined for the glucose and beech wood experiments are considered to be reasonably good, especially when considering that as little as $3-4 \mathrm{mg}$ of carbon was charged to the capillaries via the feed. 
Table 1. Yields and carbon balance of the HTC experiments with glucose solutions. ${ }^{\text {a }}$

\begin{tabular}{|c|c|c|c|c|c|c|}
\hline Test & $A^{b}$ & B & $\mathrm{C}$ & $\mathrm{D}$ & E & $\mathrm{F}$ \\
\hline & \multicolumn{6}{|c|}{ Yields } \\
\hline$<Y_{\text {gas }}>$ & 0.02 & 0.07 & 0.11 & 0.12 & 0.15 & 0.17 \\
\hline$\sigma_{\text {gas }} /<Y_{\text {gas }}>$ & 0.38 & 0.10 & 0.13 & 0.07 & 0.12 & 0.12 \\
\hline$N_{r}$ & 49 & 4 & 6 & 2 & 5 & 5 \\
\hline$<Y_{W S S}>$ & 0.1 & 0.45 & 0.41 & 0.35 & 0.34 & 0.22 \\
\hline$\sigma_{W S S} /<Y_{W S S}>$ & 0.05 & 0.04 & 0.03 & 0.03 & 0.04 & 0.02 \\
\hline \multirow[t]{2}{*}{$N_{r}{ }^{\mathrm{c}}$} & 1 & 1 & 1 & 1 & 1 & 1 \\
\hline & \multicolumn{6}{|c|}{ Carbon balance } \\
\hline$<Y_{\text {unconverted glucose }}^{C}>$ & 0.35 & 0 & 0 & 0 & 0 & 0 \\
\hline$<Y_{\text {gas }}^{C}>$ & 0.01 & 0.05 & 0.08 & 0.09 & 0.10 & 0.12 \\
\hline$\sigma_{\text {gas }}^{C} /<Y_{\text {gas }}^{C}>$ & 0.37 & 0.19 & 0.13 & 0.13 & 0.23 & 0.11 \\
\hline$N_{r}$ & 47 & 12 & 6 & 6 & 17 & 4 \\
\hline$\left.<Y_{W S S}^{C}\right\rangle$ & 0.47 & 0.63 & 0.61 & 0.55 & 0.55 & 0.34 \\
\hline$\left.\sigma_{W S S}^{C} /<Y_{W S S}^{C}\right\rangle$ & 0.02 & 0.05 & 0.02 & 0.03 & 0.07 & 0.00 \\
\hline$N_{r}{ }^{\mathrm{c}}$ & 1 & 2 & 1 & 1 & 3 & 1 \\
\hline$\left\langle Y_{W S I S}^{C}\right\rangle$ & 0.03 & 0.10 & 0.18 & 0.27 & 0.32 & 0.40 \\
\hline$\sigma_{W S I S}^{C} /<Y_{W S I S}^{C}>$ & 0.59 & 0.20 & 0.08 & 0.04 & 0.05 & 0.09 \\
\hline$N_{r}$ & 102 & 11 & 2 & 1 & 1 & 3 \\
\hline$<Y^{C}>$ & 0.86 & 0.78 & 0.87 & 0.91 & 0.97 & 0.86 \\
\hline
\end{tabular}

${ }^{\text {a }}$ Mean values $\left(<Y>,\left\langle Y^{C}\right\rangle\right)$ and standard deviations $(\sigma)$ are presented. $N_{r}=$ the number of samples required to provide a $95 \%$ confidence that the true mean of the population will be within $\pm 10 \%$ of the sample mean. Glucose concentration $=9 \mathrm{wt} \%$. Hot air oven temperature $=350{ }^{\circ} \mathrm{C}$. The reaction time differs in each test. ${ }^{b}$ reaction mixture only heated to the reaction conditions, then quenched immediately. ${ }^{c}$ One sample $=$ cumulative WSS of five capillaries.

Table 2. Carbon balance of HTC of beech wood. ${ }^{a}$

\begin{tabular}{lccc} 
& \multicolumn{3}{c}{ Catalyst to wood ratio } \\
\cline { 2 - 4 } & 0 & 0.1 & 1 \\
\hline$Y_{\text {gas }}^{C}$ & 0.09 & 0.10 & 0.19 \\
$Y_{\text {WSS }}^{C}$ & 0.54 & 0.64 & 0.84 \\
$Y_{\text {WSIS }}^{C}$ & 0.15 & 0.15 & 0.04 \\
$Y^{C}$ & 0.78 & 0.89 & 1.07
\end{tabular}

${ }^{\mathrm{a}}$ Beech wood sawdust concentration $=9 \mathrm{wt} \%$. Hot air oven temperature $=350{ }^{\circ} \mathrm{C} . \tau_{r}=600 \mathrm{~s}$.

The reproducibility of the method was evaluated by the analysis of replicate experiments with glucose (see Table 1). For the gaseous products, ten replicate experiments were performed for each process condition. For the separation and analysis of WSS, material of 20 capillaries was combined into 4 samples for each residence time $(5$ capillaries per 
sample) to ensure enough material for the analysis. The water-acetone insoluble fractions from individual capillaries were analyzed separately. On the basis of average values, the standard deviations and the number of experiments, the number of replicate experiments $\left(N_{r}\right)$ required to guarantee a maximum error of $10 \%$ for a confidence level of $95 \%$ is calculated. In the cases where the yield (and / or the carbon yield) of a certain product is low $(<0.05)$, the standard deviation is relatively high as a result of which the number of experiments required to achieve a good estimate exceeds the number that was actually used (see Table 1). For yields higher than $10 \%$ the standard deviation is typically less than $10 \%$ of the average value. Concluding, for typical non-catalytic HTC product distribution ( $\left.Y_{\text {gas }}=0.1-0.2, Y_{W S S}=0.3-0.6, Y_{W S I S}=0.05-0.25\right)$ the product recovery and the reproducibility of this extended capillary method are sufficiently accurate for exploring the operating window of HTC. For one data point a set of 10 capillaries should be processed under identical conditions; 5 capillaries for gasses and 5 for both the water-acetone soluble and insoluble products. At the extremes of the operating window with a very low yield of one the products, more experiments should be carried out (ca. 15 to 20 capillaries).

\section{Composition of the Products and Trends}

Figure 5 shows GS/MS spectra of the water-solvent soluble product of HTC of glucose (9 wt \%) after 2 min heating to $350^{\circ} \mathrm{C}\left(\tau_{h}=2, \tau_{r}=0\right)$ in the hot air oven.

Glucose and the reaction products are detected and presented as their acetylated derivates (see the Gas Chromatography with Mass Selective Detection and Gas Chromatography with Flame Ionization Detection section). On basis of the GC/MS and GC/FID analysis the glucose conversion could be calculated, this value was 0.63 in the example shown (see Figure 5). The GC/MS analysis shows that the conversion of glucose leads to the formation of compounds such as levoglucosenone, levoglucosan, and galactosan. 5hydroxymethylfurfural (5-HMF) and 1,1,2-ethantriol. Similar product distribution was as also observed by for example Srokol et al. ${ }^{7}$ and Kabyemela et al. ${ }^{8}$ The detection of high volatile compounds present in the water-acetone soluble product (e.g. glyceraldehyde, dihydroxyacetone, pyruvaldehyde, formic acid), formed by hydrothermal reactions of glucose, as described by Bonn and Bobleter ${ }^{23}$ and Kabyemela et al. ${ }^{24-26}$ was not successful in this work. It is plausible that the high volatiles were lost during the sample preparation (rotating evaporation of acetone) or that the intermediates formed during the glucose conversion were highly reactive during the acetylation and were either further decomposed or formed higher molecular weight molecules e.g. in condensation reactions. 


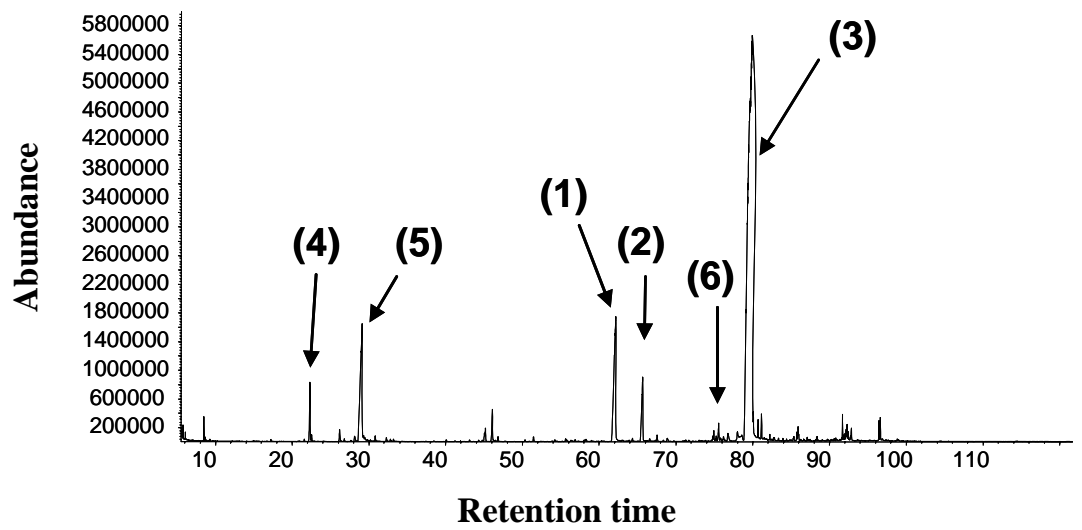

(1) $\alpha$-D-Glucopyranose 1,6-anhydro-triacetate (levoglucosan)

(2) Galactosan triacetate (galactosan)

(3) Glucose, 2,3,4,5,6-pentaacetate (glucose)

(4) 1,1,2-Triacetoxyethane (1,1,2-Ethantriol)

(5) 5-Acetoxymethyl-2-furaldehyde (5-Hydroxymethylfurfural)

(6) Fuoranthene (internal standard)

Figure 5. GC/MS of the reaction products of $\mathrm{HTC}$ of glucose $(9 \mathrm{wt} \%)$ at $350{ }^{\circ} \mathrm{C}$ and 0 min reaction time (internal standard: fluoranthene).

An example of a detected trend can be seen in Figure 6, which shows the composition of WSS product and SS (expressed in the $\mathrm{H} / \mathrm{C}$ and the $\mathrm{O} / \mathrm{C}$ ratio) from $\mathrm{HTC}$ of glucose (9 wt $\%$ ) at $350{ }^{\circ} \mathrm{C}$ versus the reaction time. Clearly, the composition of these products no longer changes after ca. 8 min reaction time.
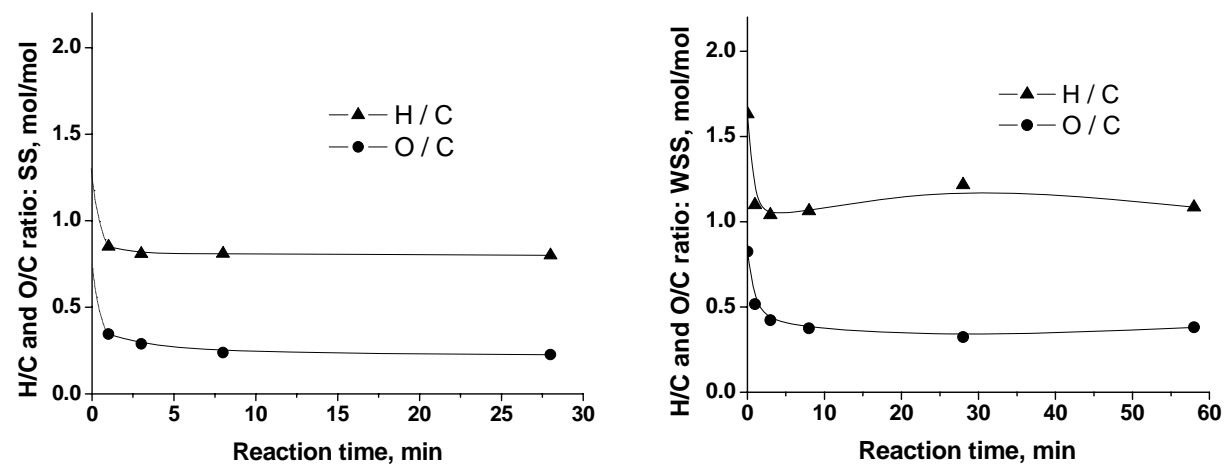

Figure 6. $\mathrm{H} / \mathrm{C}$ and $\mathrm{O} / \mathrm{C}$ molar ratios of the solvent (THF) soluble (SS); and water-solvent (acetone) soluble (WSS) product of HTC of glucose solution $(9 \mathrm{wt} \%)$ at $350{ }^{\circ} \mathrm{C}$. 


\section{Conclusions}

Separation and sample preparation methods have been developed to extend the quartz capillary high throughput screening technique with quantitative and qualitative analysis of condensed reaction products. These methods, combined with the used analysis techniques, are highly accurate with respect to the recovery of products, trend detection in yields and the composition of the products. However, the separation methods and sample preparations required are time-consuming and have a long run time due to extensive drying periods. Except for the time lag between the capillary test and the ultimate analysis of the condensed products, other advantages of working with micro-scale quartz capillaries remain; the technique is cheap and safe, visualization is possible, fast heating is achieved and reactions are carried out in the catalytically inert environment of quartz. 


\section{Notation}

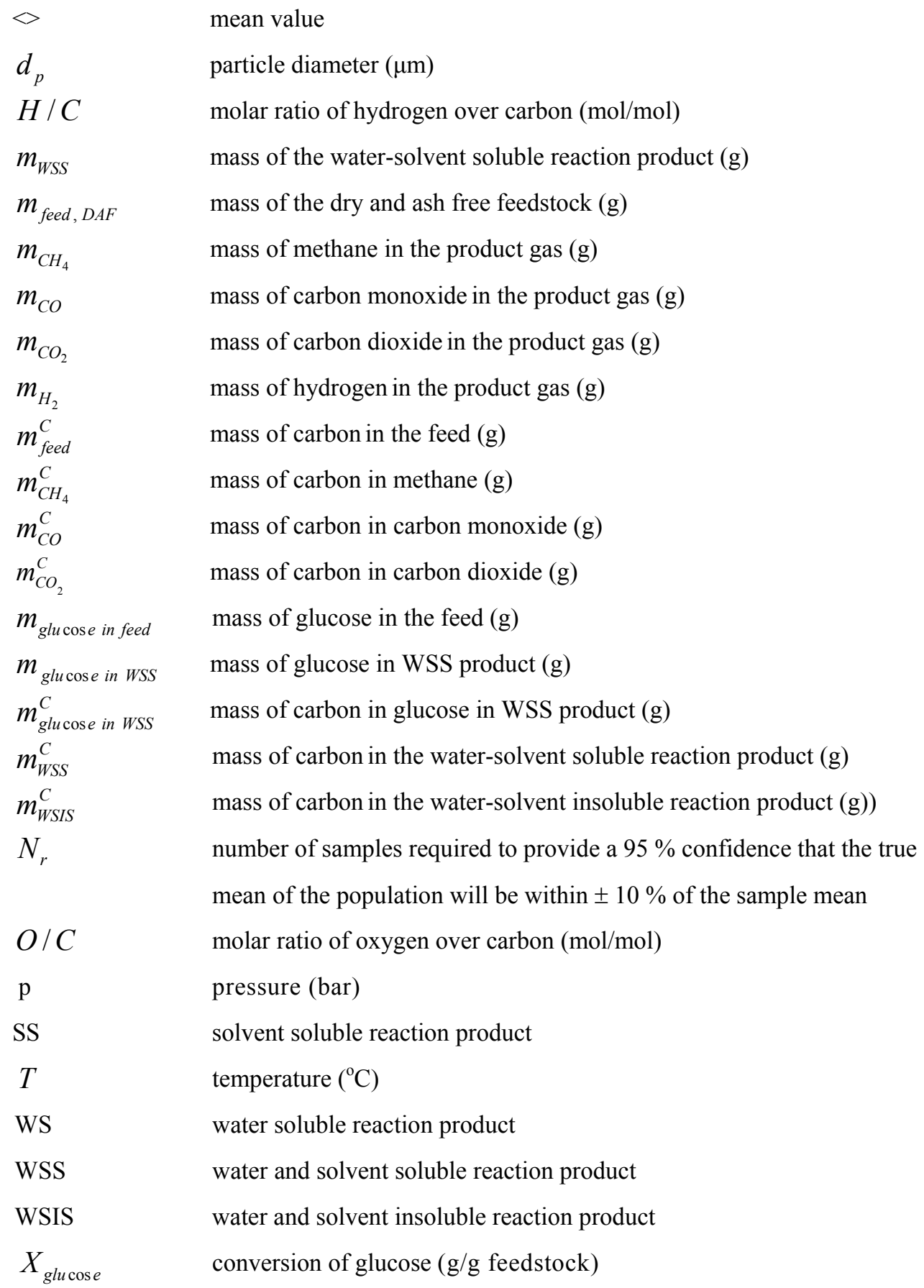

WS

WSS

WSIS

$X_{g l u \cos e}$

mean value

particle diameter $(\mu \mathrm{m})$

molar ratio of hydrogen over carbon $(\mathrm{mol} / \mathrm{mol})$

mass of the water-solvent soluble reaction product $(\mathrm{g})$

mass of the dry and ash free feedstock (g)

mass of methane in the product gas $(\mathrm{g})$

mass of carbon monoxide in the product gas $(\mathrm{g})$

mass of carbon dioxide in the product gas $(\mathrm{g})$

mass of hydrogen in the product gas $(\mathrm{g})$

mass of carbon in the feed $(\mathrm{g})$

mass of carbon in methane $(\mathrm{g})$

mass of carbon in carbon monoxide $(\mathrm{g})$

mass of carbon in carbon dioxide $(\mathrm{g})$

mass of glucose in the feed $(\mathrm{g})$

mass of glucose in WSS product $(\mathrm{g})$

mass of carbon in glucose in WSS product $(\mathrm{g})$

mass of carbon in the water-solvent soluble reaction product $(\mathrm{g})$

mass of carbon in the water-solvent insoluble reaction product $(\mathrm{g}))$

number of samples required to provide a $95 \%$ confidence that the true mean of the population will be within $\pm 10 \%$ of the sample mean molar ratio of oxygen over carbon $(\mathrm{mol} / \mathrm{mol})$

pressure (bar)

solvent soluble reaction product

temperature $\left({ }^{\circ} \mathrm{C}\right)$

water soluble reaction product

water and solvent soluble reaction product

water and solvent insoluble reaction product

conversion of glucose ( $\mathrm{g} / \mathrm{g}$ feedstock) 
product yield ( $\mathrm{g} / \mathrm{g}$ feedstock)

$Y_{\text {gas }}$

yield of the gaseous reaction product ( $\mathrm{g} / \mathrm{g}$ feedstock)

$Y_{W S S}$

yield of the water-solvent soluble reaction product ( $\mathrm{g} / \mathrm{g}$ feedstock)

$Y_{\text {WSIS }}$

yield of the water-solvent insoluble reaction product ( $\mathrm{g} / \mathrm{g}$ feedstock)

$Y^{C}$

product carbon yield ( $\mathrm{g} / \mathrm{g} \mathrm{C}$ in feedstock)

$Y_{\text {gas }}^{C}$

carbon yield of the gaseous reaction product ( $\mathrm{g} \mathrm{C} / \mathrm{g} \mathrm{C}$ in feedstock)

$Y_{\text {unconverted glucose }}^{C}$

$Y_{W S S}^{C}$

carbon yield of the unconverted glucose ( $\mathrm{g} \mathrm{C} / \mathrm{g} \mathrm{C}$ in feedstock)

carbon yield of the water-solvent soluble reaction product ( $\mathrm{g} \mathrm{C} / \mathrm{g} \mathrm{C}$ in feedstock)

$Y_{W S I S}^{C}$

carbon yield of the water-solvent insoluble reaction product $(\mathrm{g} \mathrm{C} / \mathrm{g} \mathrm{C}$ in feedstock)

\section{Greek letters}

$\sigma$

$\sigma_{\text {gas }}$

$\sigma_{W S S}$

$\sigma_{\text {gas }}^{C}$

$\sigma_{W S S}^{C}$

$\sigma_{W S I S}^{C}$

$\tau_{h}$

$\tau_{r}$ standard deviation

standard deviation of the gas yield

standard deviation of the yield of the water-solvent soluble reaction product

standard deviation of the carbon yield of the gaseous reaction products standard deviation of the carbon yield of the water-solvent soluble reaction product

standard deviation of the carbon yield of the water-solvent insoluble reaction product

heating time (s)

reaction time (s) 


\section{References}

${ }^{1}$ Potic, B.; Kersten, S. R. A.; Prins, W.; Van Swaaij, W. P. M. A high-throughput screening technique for conversion in hot compressed water. Ind. Eng. Chem. Res. 2004, 43, 4580.

${ }^{2}$ Kersten, S. R. A.; Potic, B.; Prins, W.; Van Swaaij, W. P. M. Gasification of Model Compounds and Wood in Hot Compressed Water. Ind. Eng. Chem. Res. 2006, 45, 4169.

${ }^{3}$ Yokoyama S-Y.; Ogi, T.; Kogushi, K. Process for liquefying cellulose containing biomass. US patent number 4935567, Jun 19, 1990.

${ }^{4}$ Goudriaan, F; Peferoen, D. G. R. (1990) Liquid fuels form biomass via a hydrothermal process. Chem. Eng. Sci. 1990, 45, 2729.

${ }^{5}$ Goudriaan, F.; Van de Beld, B.; Boerefijn, F. R.; Bos, G. M.; Naber, J. E.; Van der Wal, S.; Zeevalkink, J. A. Thermal efficiency of the HTU® Process for biomass liquefaction. In: Progress in Themochemical Biomass Conversion, Ed. by A. V. Bridgwater, Blackwell Science, England, 2000, pp. 1312.

${ }^{6}$ Khajavi, S. H.; Kimura, Y; Oomori, T.; Matsuno, R.; Adachi, S. Degradation kinetics of monosaccharides in subcritical water. Journal of Food Engineering 2005, 68, 309.

${ }^{7}$ Srokol, Z; Bouche, A.G.; van Estrik, A.; Strik, R.C.J.; Maschmeyer, T.; Peters, J.A Hydrothermal upgrading of biomass to biofuel; studies on some monosaccharide model compounds. Carbohydrate Research 2004, 339, 1717.

${ }^{8}$ Kabyemela, B.M.; Adschiri, T.; Malaluan, R.M.; Arai, K. Kinetics of glucose epimerization and decomposition in subcritical and supercritical water. Ind. Eng. Chem. Res. 1997, 36, 1552.

${ }^{9}$ Kruse A.; Gawlik,A.; Henningsen, T. Biomass liquefaction and gasification in near- and supercritical water: key compounds as a tool to understand chemistry. In: 4th International Symposium On High Pressure Process Technology And Chemical Engineering, Venice-Italy, September 22-25, 2002, Edited by Alberto Bertucco, AIDIC Servizi S.r.l., Italy, 2002; pp. 765.

${ }^{10}$ Eager, R.L.; Mathews, J. F.; Pepper, J. R. Liquefaction of Aspen Poplar Wood. Can. J. Chem. Eng. 1982, 60, 289.

${ }^{11}$ Boocock, D.G.B.; Sherman, K.M. Further Aspects of Powdered Poplar Wood Liquefaction by Aqueous Pyrolysis. Can. J. Chem. Eng. 1985, 63, 627.

${ }^{12}$ Molton, M. P.; Fasbender, A. G.; Robertus, R. R.; Brown, M. D.; Sullivan, R. G. Thermochemical conversion of primary sewage sludge by SORS process. In Research in Thermochemical Biomass Conversion; Bridgwater, A. V., Kuester, J. L., Eds.; Elsevier Applied Science: New York, 1988; pp 867.

${ }^{13}$ Sakaki T.; Shibata, M.; Miki, T.; Hirosue, H.; Hayashi N. Reaction model of cellulose decomposition in near-critical water and fermentation of the products. Bioresource technology 1996, 58, 197.

${ }^{14}$ Fang, Z. M., T.; Smith, Jr., R.L.; Ogi, T.; Koziski, J.A. Liquefaction and gasification of cellulose with $\mathrm{Na}_{2} \mathrm{CO}_{3}$ and $\mathrm{Ni}$ in subcritical water at 350 C. Ind. Eng. Chem. Res. 2004, 43, 2454. 
${ }^{15}$ Karagos, S.; Bhaskar, T.; Muto, A.; Sakata,Y. Comparative studies of oil compositions produced from sawdust, rice husk, lignin and cellulose by hydrothermal treatment. Fuel 2005, 84, 875.

${ }^{16}$ Murakami M.; Yokoyama, S-Y.; Minowa, T. Thermochemical Treatment Of Waste Molasses. In Advances in Thermochemical Biomass Conversion, A.V. Bridgwater, Kluwer Academic Publishers, 1993, pp.1385.

${ }^{17}$ Boocock, D. G.B.; Poretta, F. Physical aspects of the liquefaction of poplar chips by rapid aqueous thermolysis. Journal of wood chemistry and technology 1986, 6, 127.

${ }^{18}$ Beckman, D.; Boocock, D.G Liquefaction of Wood by Rapid Hydropyrolysis. Can. J. Chem. Eng. 1983, 61, 80.

${ }^{19}$ Luijkx G.C.A. Hydrothermal conversion of carbohydrates and related compounds. $\mathrm{PhD}$ thesis, Technical University Delft, 1994.

${ }^{20}$ Naber, J.E.; Goudriaan, F.; Zeevalkink J.A. Promising results from the on-going development of the HTU® process. In: 12th European Conference on Biomass for Energy, Industry and Climate Protection, Amsterdam, The Netherlands, June 17-21, 2002; ETA-Florence, Italy and WIPMunich, Germany, 2002; pp 537.

${ }^{21}$ Wakai, C; Yoshida, K; Tsujino, Y; Matubayasi, N; Nakahara, M. Effect of Concentration, Acid, Temperature, and Metal on Competitive Reaction Pathways for Decarbonylation and decarboxylation of Formic Acid in Hot Water Chemistry Letters 2004, 33, 572.

${ }^{22}$ Yu, J.; Savage, P. E. Decomposition of Formic Acid under Hydrothermal Conditions. Ind. Eng. Chem. Res. 1998, 37, 2.

${ }^{23}$ Bonn, G.; Bobleter, O Determination of the hydrothermal degradation products of D-(U- 14C) glucose and D-(U- 14C) fructose by TLC. J.Radioanal.Chem. 1983, 79, 171.

${ }^{24}$ Kabyemela, B.M.; Adschiri, T.; Malaluan, R.M.; Arai, K. Degradation kinetics of dihydroxyacetone and glyceraldehydes in subcritical and supercritical water. Ind.Eng.Chem.Res. 1997, 36, 2025.

${ }^{25}$ Kabyemela, B.M.; Adschiri, T.; Malaluan, R.M.; Arai, K. Rapid and selective conversion of glucose to erythrose in supercritical water. Ind.Eng.Chem.Res. 1997, 36, 5063.

${ }^{26}$ Kabyemela, B.M.; Adschiri, T.; Malaluan, R.M.; Arai, K. Glucose and fructose decomposition in subcritical and supercritical water: Detailed reaction pathway, mechanisms, and kinetics.

Ind.Eng.Chem.Res. 1999, 38, 2888. 


\title{
CHAPTER 3
}

\section{Hydrothermal Conversion of Biomass - Part I: Glucose Conversion in Hot Compressed Water}

\begin{abstract}
In this chapter hydrothermal conversion (HTC) $\left(250-350^{\circ} \mathrm{C}\right)$ of glucose is investigated using batch quartz capillary reactors. Kinetics of the overall glucose decomposition was determined and was in agreement with the majority of literature data. Attention was paid to the initial glucose decomposition: primary glucose decay products were identified from literature and used in experiments. It was found that all primary decay components of glucose, with the exception of formaldehyde, produce a kind of char (acetone insoluble product). Characteristic gas (primarily $\mathrm{CO}_{2}$ ) formation reactions are discussed on the basis of separate tests with primary and other known initial glucose degradation products. Complete mass and elemental balances were obtained for two different temperatures, 300 and $350{ }^{\circ} \mathrm{C}$, and various residence times from $10 \mathrm{~s}$ to 10 days. Two distinct rates of product formation are observed as a function of residence time, a fast rate in the first 5-10 min, and a much slower rate after this time. It was found that water production, which occurred predominantly in the first 5 min of residence time, was constant ( $3 \mathrm{~mol} / \mathrm{mol}$ glucose) and unaffected by temperature or glucose concentration. The yield of the oil product, called here water-acetone soluble (WSS) yield exhibited a maximum at ca. 5 min residence time. After 5 min it was reduced in favor of gas and char, called here water-acetone insoluble (WSIS). However, a certain quantity of WSS is stable even after 10 days residence time. The elemental composition of WSS and WSIS was found to be very similar suggesting that they are essentially the same product, fractioned by our separation method according to the solubility in acetone. Compositions of gas, WSS, and WSIS were used as a basis for estimation of the overall reaction enthalpy, which was calculated to be $\Delta H_{r}=1.5 \pm 0.5 \mathrm{MJ} / \mathrm{kg}$. It was found that higher glucose concentrations resulted in more WSIS and less WSS, whereas the gas and water yield did not change. All findings were incorporated into a lumped engineering reaction path and kinetic model of glucose hydrothermal decomposition.
\end{abstract}




\section{Introduction}

Hot compressed water is proposed and used as reaction medium in liquefaction, ${ }^{1-12}$ gasification, ${ }^{13-26}$ and combustion ${ }^{27-32}$ processes of biomass. It is an excellent solvent for organic components and gases, and near the critical point it is an acid/ base catalyst because of its high ionic product $\left(K_{\mathrm{w}}=10^{-11}\right) \cdot{ }^{33,34}$ Another benefit of working at high pressure is the marginal heat of vaporization of water $\left(\Delta H_{v}\right.$ decreases from $2.26 \mathrm{MJ} / \mathrm{kg}$ at ambient pressure, to zero above the critical point). This will keep shell-to-tube temperature differences in a counter-current heat exchanger, operating between the reactor effluent and the feed stream, finite. As a result of this, high thermal efficiencies can be achieved despite a low dry matter content of the feedstock..$^{24,25}$ Depending on the process conditions and application of catalysis, the main reaction product can be a gas or a liquid (oil).

Hydrothermal gasification experiments at laboratory and pilot scale are reported over the whole temperature range of 250 to $650{ }^{\circ} \mathrm{C} .{ }^{13-17,19-26}$ A catalyst is necessary to achieve complete gasification. ${ }^{17,24,26}$ By choice of temperature and catalyst design/selection, it has been possible to steer the gas composition, at least partly, toward methane or hydrogen. Methane production from biomass in the temperature range of 350 to $400{ }^{\circ} \mathrm{C}$ has been demonstrated at pilot scale and is now being commercialized, ${ }^{15}$ whereas the production of hydrogen is more difficult and still in an embryonic stage of development. ${ }^{20,24}$ Production of hydrogen-rich gas is difficult because a high $\mathrm{CH}_{4}$ yield is dictated by thermodynamics for low temperature and also for high temperature in combination with realistic feedstock concentrations of $>10 \mathrm{wt} \%$ organics. Only for diluted feed streams (less than $2 \mathrm{wt} \%$ carbohydrates in water) and high temperature $\left(T>600{ }^{\circ} \mathrm{C}\right)$ the production of high concentration of hydrogen is thermodynamically possible. ${ }^{35}$

In this chapter, hydrothermal conversion (HTC) aiming at oil production is investigated. HTC is performed in the temperature range between $240{ }^{\circ} \mathrm{C}$ and the critical point of water $\left(374{ }^{\circ} \mathrm{C}\right)$ with or without catalyst. ${ }^{1-10}$ Under these conditions, biomass is converted, in a complex sequence of chemical reactions, into various components, which, upon cooling the reactor effluent, constitute three different phases: a water phase, a hydrophobic phase, and a gas phase. By extraction, the hydrophobic reaction product can be further separated into a solvent soluble (oil) and a solvent insoluble (char) part. The hydrophobic product has a considerably lower oxygen content (typically $20 \mathrm{vs} .45 \mathrm{wt} \%$ of the feedstock) and, consequently, a higher heating value (HHV) than the feedstock (typically $30,{ }^{6}$ vs. $19^{36}$ $\mathrm{MJ} / \mathrm{kg}$ ). The whole hydrophobic product can be used as fuel in furnaces and boilers. ${ }^{2,6}$ It is reported that the solvent soluble fraction (oil) of the hydrophobic product can be upgraded into transportation fuel by catalytic hydro-treatment., ${ }^{2,6}$ This chapter deals with the measurement of kinetic and yield data necessary for process development. Despite the fact that non-catalytic HTC of biomass has been a research subject of numerous studies, only a 
limited number of detailed complete mass and elemental balances are presented in literature. ${ }^{1,21,37-42}$ Information is lacking, or at best incomplete, on reaction rates, product yields, and product compositions as a function of residence time, reaction temperature, and concentration of organic material in the feedstock and/or inside the reactor.

The influence of the concentration on reaction rates and yields did not receive enough attention in the open literature. Only a few publications point toward this effect and recognize its importance in subcritical water ${ }^{9,10}$ and supercritical water. ${ }^{19,24}$ In addition, previous kinetic/mechanistic work on biomass conversion in hot compressed water is often based on diluted feedstock solutions (less than $1 \mathrm{wt} \%$ organics in water ${ }^{43-47}$ ), which are far from those expected for industrial processes. ${ }^{6,712}$

We have performed ca. 600 conversion experiments with glucose, pyrolysis oil, and wood while varying the residence time in the range of $10 \mathrm{~s}$ to 10 days and the reaction temperature in the range of 250 to $350{ }^{\circ} \mathrm{C}$ and using different initial concentration of organics. In the case of glucose, initial concentrations were varied in the range 0.73 to 162 $\mathrm{g} / \mathrm{L}$. Lumped component reaction path model and kinetic relations have been derived on the basis of these measurements. We have aimed at deducing the simplest workable models from the experimental data that are acceptable to start the process design, rather than concentrating on the most optimal fit of the models and its parameters to these data. The oil-like product is considered to be the most valuable, especially if it has reduced oxygen content in comparison with the original feed. In addition to this product, special attention is given to the formation of a char-like product which has a low value and can only be sold for its heating value. Furthermore, this product tends to deposit on surfaces (e.g., reactor, heat exchanger) and is generally difficult to separate from the rest of the hydrophobic organic phase (in this work solvent extraction was used). This causes complications in the process. For all of these reasons, minimization of this char product is desired.

Another point of interest in this work is the oxygen removal during HTC. This is beneficial in terms of increasing the heating value of the products and is crucial for co-feeding biomass in standard refinery units. ${ }^{48}$ Therefore the fate of oxygen from biomass is discussed here in more detail. This chapter summarizes the methods used and presents results of glucose.

\section{Product Definitions}

Condensed products are lumped according to their solubility in acetone. The acetone soluble product consists of water soluble components and hydrophobic components, but because the whole reactor effluent is washed with an excess of acetone, in which the watersoluble organics also practically completely dissolve, a combined product phase is created. ${ }^{49}$ The organics in this phase are called Water-Solvent Soluble (WSS) organics and 
the product is referred to as oil because of its oily appearance. Condensed components that are not soluble, at ambient conditions, in water and acetone are called Water-Solvent InSoluble (WSIS) organics. These WSIS organics, once separated, form a solid product at room temperature and are referred to as char. The gaseous products include those gases with a normal boiling point lower than $250 \mathrm{~K}$. For a more detailed description of the lumped products, the reader is referred to Knežević et al. ${ }^{49,50}$

\section{Experimental Set-Ups and Procedures}

Detailed descriptions of the experimental set-ups, workup procedures, and analysis methods can be found in our previous publications on biomass conversion in hot compressed water. $^{24,49}$ Here they will be summarized in short. As feedstock we used D-glucose and several glucose derivates suspected to play a role as intermediate in the glucose conversion. The purity of all components was above $98 \mathrm{wt} \%$.

\section{Quartz Capillary Reactors}

Quartz capillaries of $2 \mathrm{~mm}$ i.d., $4 \mathrm{~mm}$ o.d., and ca. $150 \mathrm{~mm}$ in length (V $\approx 0.5 \mathrm{~mL}$ ) were used as batch micro reactors. Balance with an accuracy of $0.1 \mathrm{mg}$ was used to weigh the samples. The capillaries were charged with the given amount of feedstock and sealed by melting in a hydrogen flame. Prior to sealing, the gas caps of the capillaries were flushed with nitrogen to remove oxygen. The capillaries were heated to the desired temperature in an oven. Vigorous shaking of the capillaries during the reaction was necessary to achieve good mixing in catalytic experiments and when using solid biomass as feed. This was achieved by placing the capillaries on an off-centered holder attached to a pneumatic piston. A certain amount of water evaporated upon heating and created pressure inside the capillary. Reported concentrations of the solutions are based on the liquid water amount present initially (at room temperature). In case the feedstock contained a low amount of organics, the pressure inside the capillary under reaction conditions was estimated to be the vapor pressure of water at the prevailing temperature. If a more precise estimate was required, the pressure was calculated on the basis of the initial amount of water present in the capillary and the measured amount of product gases (at atmospheric pressure). Two types of ovens were used, namely, a hot air oven and a fluidized bed heater. The heating times ( $\tau_{\mathrm{h}}$ : time until $95 \%$ of set point temperature was reached) of the ovens were 12 and $140 \mathrm{~s}$, respectively. Because chemical reactions proceed already in the heating trajectory, results are discussed against the total residence time that the capillaries were inside the ovens, which is defined as the total time span from insertion in the oven until quenching $(\tau)$. 
The presented results are characterized with the end (set-point) temperature and the oven used for heating (fluidized or hot air oven). A cold water bath was used to quench the capillaries in order to terminate the reactions. For each data point, on average some 10 capillaries were processed. Five of which were used for individual gas analysis, and the acetone extract of the remaining five capillaries were combined to obtain enough material for WSS sample analysis. The WSIS materials of at least 2 (up to 5 capillaries per data point) were collected and analyzed separately.

\section{Product Recovery and Workup}

For each gas analysis a capillary was smashed in a metal sampling chamber prefilled with helium. A gas sample was taken from this chamber and analyzed by gas chromatography (GC). The chamber had a defined volume and accurately known temperature and pressure to determine the quantity of the gaseous products from the observed GC readings. The content of five capillaries was extracted using acetone and separated over glass filters (each capillary over a different filter). After the filtrates were combined, acetone was removed by rotary vaporization and the WSS sample was dried. In the vaporization procedure some losses of highly volatile compounds of the WSS product was inevitable.

A balance with an accuracy of $0.1 \mathrm{mg}$ was used to measure the weight of the dried WSS sample. The filters plus deposits were dried separately. It was not possible to determine the mass of WSIS product by measuring the weight of the filters prior and after deposition, because beside the WSIS product, the filters also contained an unknown amount of glass splinters from the broken capillaries. Instead, the filter plus deposit was combusted and the mass of WSIS product was calculated from the weight difference of the filter prior to and after combustion. The accuracy of this analysis remained only fair. Therefore, the yield of the WSIS product was also calculated from the atomic balances of $\mathrm{C}, \mathrm{H}$, and $\mathrm{O}$.

\section{Products Analysis}

The weight fractions of the elements $\mathrm{C}$ and $\mathrm{H}$ of the WSS and WSIS products were determined with an elemental analyzer (Fisons Instruments). Oxygen was calculated by difference.

GC/MS (Agilent) was used to identify and quantify discrete components in the WSS product phase. Anion exchange chromatography (Agilent) was used to quantify the presence of non-reacted glucose in the WSS product phase. The following procedure was applied: Stationary phase: strong anion exchange resin MCI gel CA08F (Mitsubishi), packed in an Omnifit glass column $7 \times 11.5 \mathrm{~mm}$, isothermal at $60{ }^{\circ} \mathrm{C}$; Mobile phase: 0.7 
$\mathrm{mL} / \mathrm{min}$ gradient elution with $\mathrm{A}: \quad 0.3 \mathrm{M}$ potassiumtetraborate, $\mathrm{B}: \quad 0.9 \mathrm{M}$ potassiumtetraborate; Gradient profile: 0-30 min: $90 \%$ A, 10\% B, 35-47 min: 10\% A, 90\% $\mathrm{B}, 47$ min: end; postcolumn derivatization with addition of cubicinchoninate $(0.35$ $\mathrm{mL} / \mathrm{min}$ ), heating to $105^{\circ} \mathrm{C}$ in a $0.3 \mathrm{~mm}$ id, $30 \mathrm{~m}$ long Teflon coil; detection UV detector at $560 \mathrm{~nm}$.

GPC (Agilent) was used to determine the molecular weight distribution of the WSS product. The GPC was calibrated in the range of 162 to $30230 \mathrm{~g} / \mathrm{mol}$ with polystyrene. The following settings were used: Flow rate: $1 \mathrm{~mL} / \mathrm{min}$; Detectors: UV (254 nm) and RI; Columns: 3 PLgel $3 \mu \mathrm{m}$ MIXED-E (length $300 \mathrm{~mm}$, i.d. $7.5 \mathrm{~mm}$ ) in series; Column temperature $35^{\circ} \mathrm{C}$; Solvent: THF stabilized with BHT; Injection volume: $20 \mu \mathrm{L}$.

\section{Definitions of Conversion and Yields}

The conversion $(X)$ and yields $(Y)$ were calculated using the equations given in the previous section (see chapter 2 eq. 1-4). However, here the unconverted glucose, which was recovered as part of the WSS phase, is determined by anion exchange chromatography (see section: Product Analysis).

The cumulative carbon yield $\left(Y^{C}\right)$ was used to evaluate the mass balance closure, because only the carbon in the product can be related unequivocally to the feedstock. The cumulative carbon yield was calculated as follows:

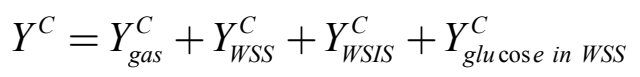

where carbon yields $\left(Y_{\text {gas }}^{C}, Y_{W S S}^{C}, Y_{W S I S}^{C}\right.$ and $Y_{g l u \text { cose in WSS }}^{C}$ ) were defined in the previous chapter (see chapter 2, eq. 5-8).

Molar ratios for all the products were defined as:

$$
\begin{aligned}
& (H / C)=\frac{m_{H} / M_{H}}{m_{C} / M_{C}} \\
& (O / C)=\frac{m_{O} / M_{O}}{m_{C} / M_{C}}
\end{aligned}
$$

For WSS, the molar ratios are defined excluding unconverted glucose. 


\section{Calculation of the Water and WSIS Yield}

It was not possible to measure the water yield directly, because the produced water had to be determined against a background of an excess of water (90 to $98 \%$ of the WSS product was water). However, the water yield could be calculated from the atom balances of $\mathrm{C}$ and $\mathrm{H}$. The bases for this calculation were the normalized measured carbon yields and the measured composition of gas, WSS and WSIS. Normalization was performed by dividing the individual carbon yields by the carbon recovery. For dry feedstock of molecular formula $\mathrm{C}_{\mathrm{i}} \mathrm{H}_{\mathrm{j}} \mathrm{O}_{\mathrm{k}}$ hydrogen balance reads:

$$
\begin{aligned}
j=j & \cdot(1-X)+i \cdot\left[Y_{\text {gas }}^{C} \cdot(H / C)_{\text {gas }}+Y_{W S S}^{C} \cdot(H / C)_{W S S}+Y_{W S I S}^{C} \cdot(H / C)_{W S I S}\right]+ \\
& 2 \cdot Y_{\mathrm{H}_{2} \mathrm{O}} \cdot \frac{M_{\text {feedstock }}}{M_{\mathrm{H}_{2} \mathrm{O}}}
\end{aligned}
$$

which after rearrangement in case of glucose gives the water yield:

$$
\begin{aligned}
Y_{\mathrm{H}_{2} \mathrm{O}}= & \left\{6 \cdot X-3 \cdot\left[Y_{\text {gas }}^{C} \cdot(H / C)_{\text {gas }}+Y_{\text {WSS }}^{C} \cdot(H / C)_{\text {WSS }}+Y_{W S I S}^{C} \cdot(H / C)_{\text {WSIS }}\right]\right\} . \\
& \frac{M_{\mathrm{H}_{2} \mathrm{O}}}{M_{\text {glucose }}}
\end{aligned}
$$

If the experimental value for char was missing, this value was calculated from the $\mathrm{C}$ and $\mathrm{O}$ balance. From the oxygen balance (eq. 6) (including the calculated water yield via eq. 5), the oxygen in WSIS $\left((O / C)_{W S I S}\right)$ could be calculated, with which the $Y_{W S I S}$ could be calculated (eq. 7). The generalized equations are as follows:

$$
\begin{gathered}
k=k \cdot(1-X)+i \cdot\left[Y_{\text {gas }}^{C} \cdot(O / C)_{\text {gas }}+Y_{W S S}^{C} \cdot(O / C)_{W S S}+Y_{W S I S}^{C} \cdot(O / C)_{W S I S}\right]+ \\
Y_{H_{2} O} \cdot \frac{M_{\text {feedstock }}}{M_{H_{2} O}} \\
Y_{W S I S}=Y_{W S I S}^{C} \cdot\left[(O / C)_{W S I S} \cdot \frac{M_{O}}{M_{C}}+(H / C)_{W S I S} \cdot \frac{1}{M_{C}}+1\right] \cdot \frac{i \cdot M_{C}}{M_{\text {feedstock }}}
\end{gathered}
$$

We realize that this calculation procedure involves many accumulating errors. However, Figure 3 shows that the calculated WSIS yields are positioned well on the trend line of the 
measured WSIS yields. Where available, the difference between the measured and calculated WSIS yields was evaluated to be a maximum of $19 \%$ (relative to the measured values).

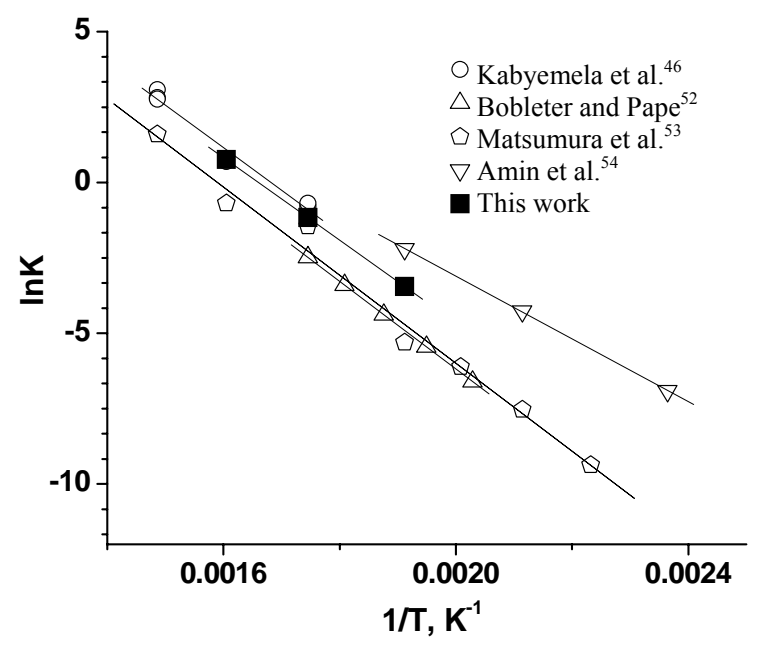

Figure 1. Comparison of reaction parameters of the HTC of glucose while assuming a first-order reaction.

\section{Heating Values}

The higher heating values (HHV) of glucose and gases are calculated from tabulated enthalpies of formation. The HHV of WSIS and WSS is estimated by Reed's correlation. ${ }^{51}$

\section{Experimental Results}

\section{Decomposition Rate of Glucose}

The decomposition rate of glucose in water was the subject of several previous studies. Kabyemela et al., ${ }^{46}$ Bobleter and Pape, ${ }^{52}$ Matsumura et al., ${ }^{53}$ and Amin et al. ${ }^{54}$ found activation energies of respectively: 96, 120.9, 121, and $87.8 \mathrm{~kJ} / \mathrm{mol}$ (see Figure 1) while interpreting the data with a single decay reaction of the first order in the glucose concentration. Bobleter and Pape ${ }^{52}$ observed that first order reaction kinetics described the 
measured data well from 0 to $90 \%$, but overestimated the measured rate in the last $10 \%$ of the conversion. They ascribed this to build up of organic acids in the reaction mixture, which, as they claimed, slowed down the reaction. Data of Matsumura et al. ${ }^{53}$ showed that the relative conversion rate is affected by the initial glucose concentration. In their study, the overall reaction order in the glucose concentration was fitted to be a function of temperature and decreased from first order at $175^{\circ} \mathrm{C}$ to order 0.7 at $300{ }^{\circ} \mathrm{C}$. This effect of temperature on the reaction order was ascribed to the transition in the dominant reaction mechanism from ionic to radical with the increase in temperature.

Because of the differences between the reported rate data (see Figure 1), it has been decided to measure the kinetic data of glucose decomposition in our own system. These data are used to describe the rate of the first steps in the developed lumped component reaction pathway model including the formation of gas, water, WSS, and WSIS products (see section: Reaction Path Model and Kinetics). The relative glucose conversion was measured versus the residence time in the batch capillary reactors at end temperatures of 250, 300, and $350{ }^{\circ} \mathrm{C}$ for initial glucose concentrations of $0.73,8.6,77$, and $155 \mathrm{~g} / \mathrm{L}$ (see Figure 2). To approach isothermal conditions as much as possible, the fluidized bed heater $\left(\tau_{h}=12 \mathrm{~s}\right)$ was used. However, it turned out that, despite the fast heating in the fluidized bed, a significant part of the conversion took place in the heating trajectory when working at an end temperature of $350{ }^{\circ} \mathrm{C}$. To overcome this problem, the heating trajectory was incorporated in the interpretation model. The data were fitted to the following model:

$$
\begin{aligned}
& \frac{d X}{d t}=k_{0} \cdot e^{\frac{-E_{a}}{R T}} \cdot C_{g, 0}^{n-1} \cdot(1-X)^{n} \\
& \frac{d T}{d t}=B \cdot\left(T^{\infty}-T\right)
\end{aligned}
$$

Table 1. Reaction parameters for glucose decay in hot compressed water. ${ }^{\text {a }}$

\begin{tabular}{lcc} 
& first order & variable order \\
\hline $\mathrm{n}$ & 1 & 0.9 \\
$\mathrm{k}_{0}, \mathrm{~g}^{(1-\mathrm{n}) * \mathrm{~L}^{\mathrm{n}-1} * \mathrm{~s}^{-1}}$ & $7.7 \times 10^{8}$ & $1.0 \times 10^{9}$ \\
$\mathrm{E}_{\mathrm{a}}, \mathrm{kJ} / \mathrm{mol}$ & 114 & 114 \\
$C_{\mathrm{g}, 0}=0.73-155 \mathrm{~g} / \mathrm{L}$. & &
\end{tabular}

In the fit procedure, all measured data were fitted simultaneously to the model. B in eq. 9 was determined experimentally in dedicated experiments by measuring the temperature rise inside a capillary after placement in the heaters. ${ }^{24,49}$ When assuming a reaction order of one, 
the best fit was obtained for $k_{0}=7.7 \times 108 \mathrm{~L}^{*} \mathrm{~s}^{-1}$ and Ea $=114 \mathrm{~kJ} / \mathrm{mol}$ (see Table 1). The activation energy calculated here is in good agreement with those reported by Kabyemela et al., ${ }^{46}$ Bobleter and Pape, ${ }^{52}$ and Matsumura et al. ${ }^{53}$

a)

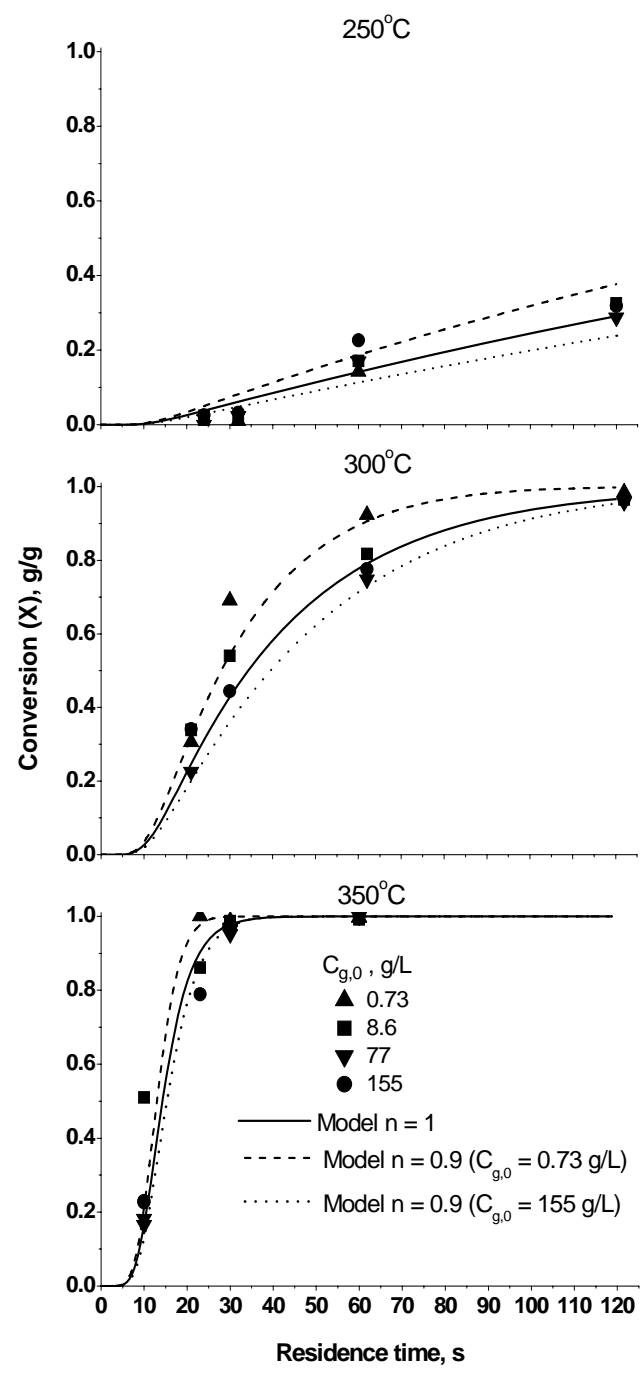

b)

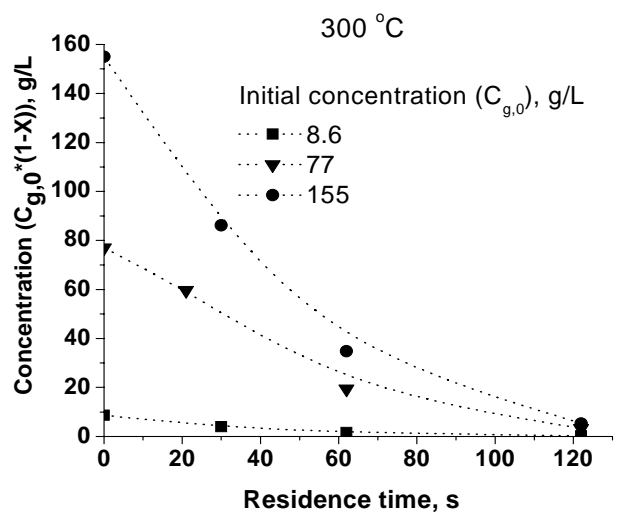

Figure 2. (a) Glucose conversion $(\mathrm{X})$ versus residence time and (b) glucose concentration $\left(\mathrm{C}_{\mathrm{g}, 0}\right.$ * $(1$ $\mathrm{X})$ ) versus residence time. Conditions: (a) $\mathrm{T}^{\infty}=250,300$, and $350{ }^{\circ} \mathrm{C}, \mathrm{C}_{\mathrm{g}, 0}=0.73,8.6,77,155 \mathrm{~g} / \mathrm{L}$, (b) $\mathrm{T}^{\infty}=300{ }^{\circ} \mathrm{C}, \mathrm{C}_{\mathrm{g}, 0}=8.6,77$, and $155 \mathrm{~g} / \mathrm{L}$. In (a) lines are model predictions and in (b) dotted lines are trend-lines. The fluidized bed oven was used in all experiments. 
Despite the scatter of the data, Figure 2 clearly shows that there is an effect of the initial glucose concentration on the relative conversion rate $(\mathrm{dX} / \mathrm{dt})$ and on the conversion rate $\left(\mathrm{dC}_{\mathrm{g}} / \mathrm{dt}\right)$. At 300 and $350{ }^{\circ} \mathrm{C} \mathrm{dX/dt}$ increases and $\mathrm{dC}_{\mathrm{g}} / \mathrm{dt}$ decreases as the initial concentration decreases (see Figure 2: for lower initial glucose concentration, the slope of $\mathrm{X}$ vs. time is larger, while the slope $\mathrm{C}_{\mathrm{g}, 0} *(1-\mathrm{X})$ vs. time is smaller). Hence, the overall reaction order (n) is larger than zero and smaller than one. At $250{ }^{\circ} \mathrm{C}$ the concentration effect on the relative rate has not been observed or is not large enough to be noticed against the background of the scatter on the data. Following the suggestion of Bobleter and Pape ${ }^{52}$ that the produced organic acids in the glucose decay set a weak acid environment that stabilizes glucose, an attempt was made to investigate the effect of $\mathrm{pH}$ of the solution on the glucose conversion rate. The decomposition rate was measured at $300{ }^{\circ} \mathrm{C}$ and $30 \mathrm{~s}$ for solutions of glucose of different initial $\mathrm{pH}$ ( 1 to 14). No clear trends have been observed in these tests, and therefore the influence of $\mathrm{pH}$ on the kinetics remains inconclusive. When including the reaction order in the fit procedure, the best fit has been obtained for $\mathrm{n}=0.9$, $\mathrm{k}_{0}=1.0 \times 10^{9} \mathrm{~g}^{0.1} * \mathrm{~L}^{-0.1} * \mathrm{~s}^{-1}$ and $\mathrm{E}_{\mathrm{a}}=114 \mathrm{~kJ} / \mathrm{mol}$ (see Table 1 ).

It has been found that the fit can be somewhat improved by introducing a temperature dependence of $n$, like Matsumura and co-workers ${ }^{53}$ did. However, this model extension has been considered inappropriate for our data in view of the scatter.

In the investigated ranges, the temperature has a much stronger effect on the relative conversion rate than the initial glucose concentration (see Figure 2). Therefore, in view of the engineering nature of the kinetic model, it has been decided that working further with the assumption of $n=1$ would provide sufficient accuracy.

\section{Product Yields and Composition at 300 and $350{ }^{\circ} \mathrm{C}$ for $C_{g, 0}=88 \mathrm{~g} / \mathrm{L}$}

In Figure 3, the yields and carbon yields at 300 and $350{ }^{\circ} \mathrm{C}$ are plotted as a function of residence time.

The carbon yield $\left(Y^{C}\right)$ in these series, including unconverted glucose, is in the range of 0.86 to $1.01 \mathrm{~g} / \mathrm{g}$. Reproducibility and precision of the yields is expressed as the standard deviation divided by the mean value. The maximum values of this precision/scatter indicator are $0.15,0.05$, and 0.10 for gas, WSS, and WSIS, respectively, and are used to evaluate if trends are statistically sound.

Next to experimental results also model predictions are presented. These model predictions will be discussed in the section Reaction Path Model and Kinetics.

Figure 3 shows that WSS is the first product formed during glucose decomposition. Downhill the maximum WSS yield, the decay rate of WSS is first relatively fast, and then slows down. The data at $350{ }^{\circ} \mathrm{C}$ for long residence times show that a certain part of the 
WSS product cannot be converted, or can only be converted into other products at a very low rate. Initially, the water yield increased along with the WSS yield.
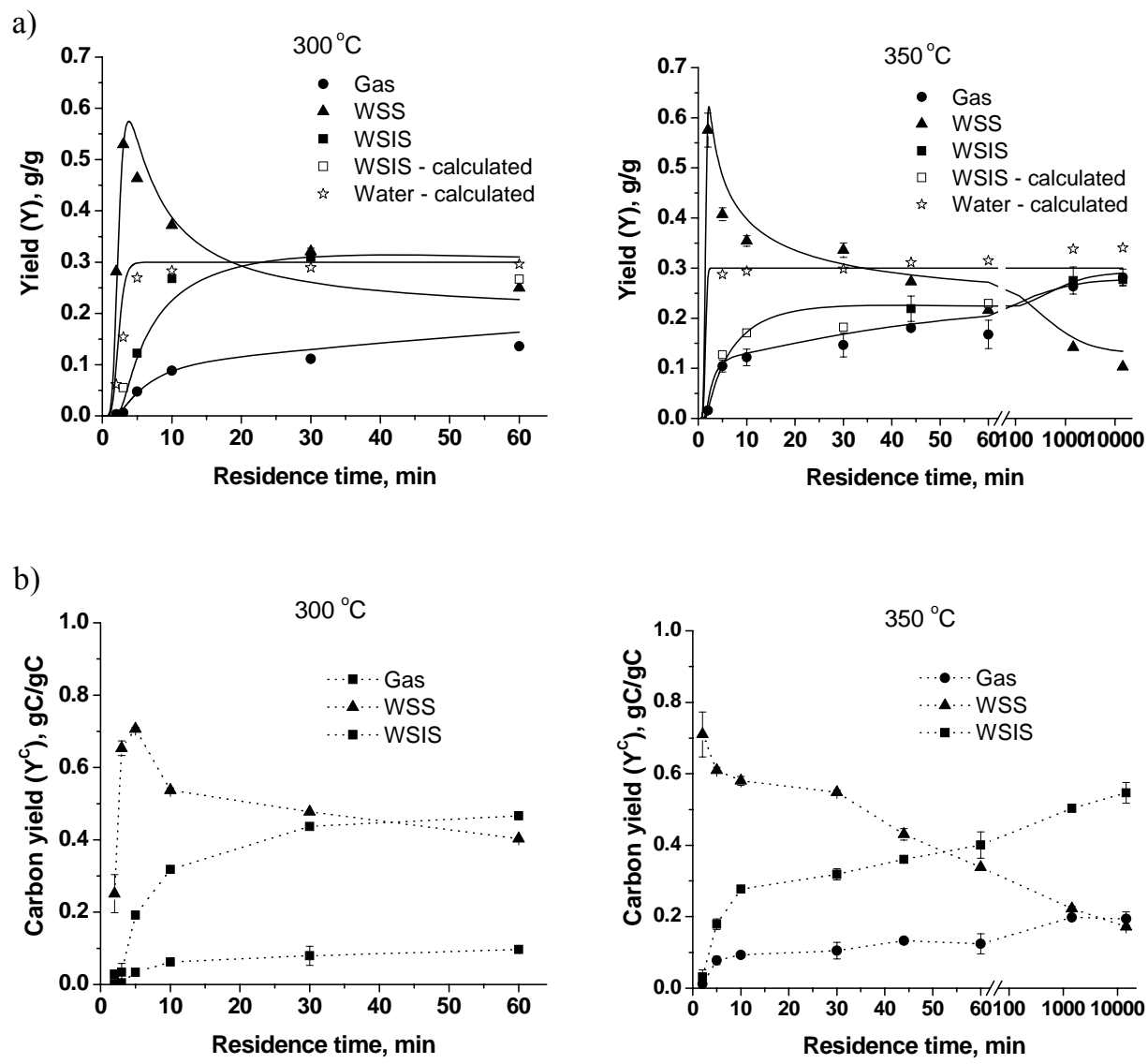

Figure 3. (a) Yields and (b) carbon yields of glucose conversion versus residence time. Conditions: $\mathrm{T}^{\infty}=300$ and $350{ }^{\circ} \mathrm{C}, \mathrm{C}_{\mathrm{g}, 0}=88 \mathrm{~g} / \mathrm{L}$. Full lines are model predictions (see section: Reaction Path Model and Kinetics). Dotted lines are trend-lines. The hot air oven was used.

After the maximum WSS yield, the water yield remained nearly constant, which indicates that water is mainly produced together with the initial WSS product. In the first 10 min gas and WSIS are formed with relatively high rates, from $10 \mathrm{~min}$ to 1 day, the gas and WSIS production rates are much lower. From $1440 \mathrm{~min}$ (1 day) to $14400 \mathrm{~min}$ (10 days), the change in gas and WSIS yields is not large enough to be considered significant in view of the scatter of the data. The measured yield data support the earlier proposed reaction pathway models, ${ }^{55,56}$ in which glucose is converted into oil (WSS). This oil then partly 
reacts further to gas and char (WSIS). The suggestion of Várhegyi et al. ${ }^{57}$ that all WSS components are intermediate products that are eventually converted to gas and WSIS is not supported by our data. Even after 10 days, we clearly find WSS product.

Comparison of the yield data for 300 and $350{ }^{\circ} \mathrm{C}$ shows that at $350{ }^{\circ} \mathrm{C}$ the gas yield is higher and the WSIS is lower. The WSS yield could be considered the same, taking into account the scatter of the data.

The same trends can be observed in the carbon distribution. As the H/C ratios of WSS and WSIS are essentially very similar (see Figure 5), the yields of these products are directly reflected in the carbon distribution. The change in the gas amount, however, seems to be more pronounced in case of total yields because of the oxygen contained in the $\mathrm{CO}_{2}$.

Detailed observations regarding the composition of the lumped products are further discussed below for each product individually.

\section{Gas}

The produced gas consists primarily of $\mathrm{CO}_{2}\left(\sim 80\right.$ vol. \%). Next to $\mathrm{CO}_{2}$, in the order of decreasing yield, also $\mathrm{CO}, \mathrm{CH}_{4}$ and $\mathrm{H}_{2}$ are formed (see Table 2). After $30 \mathrm{~min}$ the gas yields $\left(Y_{\text {gas }}\right)$ are $0.11 \mathrm{~g} / \mathrm{g}$ at $300{ }^{\circ} \mathrm{C}$ and $0.15 \mathrm{~g} / \mathrm{g}$ at $350{ }^{\circ} \mathrm{C}$. These gas yields and compositions correspond to an oxygen removal via decarboxylation of 15 and $20 \%$ at respectively 300 and $350{ }^{\circ} \mathrm{C}$. Minowa et al. ${ }^{56}$ suggested that gas is mainly produced from water soluble decay products.

To identify which of the initial decay products of glucose, which are all soluble in water, are responsible for gas production, all reported primary and key small secondary/ tertiary decay products were reacted under $\mathrm{HTC}$ conditions in the capillaries at $350{ }^{\circ} \mathrm{C}$ for $30 \mathrm{~min}$. Primary and small secondary/tertiary decomposition products of glucose conversion in hot compressed water were identified by a number of researchers. ${ }^{22,23,39,43,46,47,53,58-66}$ In the capillaries, gas yields and compositions of these components were determined. Formation of WSIS was observed by visual inspection and is, thus, only indicative. Results of these experiments are listed in Table 2.

The results in Table 2 show that of the primary decay products, only HMF and dihydroxyacetone almost do not produce any gases. Formaldehyde, which is both a primary and a secondary/tertiary reaction product, forms significant amount of gas (48 wt \%). The other primary glucose decomposition products, fructose, levoglucosan, erythrose, glycolaldehyde, furfural, and glyceraldehyde, produce individually about as much gas as glucose. Formic acid, which is a secondary/tertiary product, is completely converted to gases under HTC conditions. For all of the early glucose decomposition products (see section: Reaction Path Model and Kinetics), $\mathrm{CO}_{2}$ constitutes the most of the gaseous product. Mechanistic literature on the conversion of glucose shows that of the primary 
decay products only formaldehyde produces gases directly. Gas formation is claimed to go primarily via small secondary and tertiary decay products like, for instance, formic acid ${ }^{67}$ and formaldehyde.

Table 2. Gas yield and composition and qualitative char formation indication of HTC of glucose and its primary and secondary/tertiary decay products ${ }^{\mathrm{a}}$

\begin{tabular}{|c|c|c|c|c|c|c|c|c|c|c|c|}
\hline \multirow[b]{2}{*}{ Component $^{\mathrm{b}}$} & \multirow{2}{*}{$\begin{array}{c}Y_{g a s} \\
\mathrm{~g} / \mathrm{g}\end{array}$} & \multirow{2}{*}{$\begin{array}{c}Y_{g a s}^{C} \\
\mathrm{~g} / \mathrm{g}\end{array}$} & \multicolumn{4}{|c|}{$\begin{array}{c}\text { Gas yield } \\
\text { mol gas } / \text { mol feedstock }\end{array}$} & \multicolumn{4}{|c|}{$\begin{array}{c}\text { Gas composition } \\
\mathrm{mol} / \mathrm{mol} \text { gas }\end{array}$} & \multirow{2}{*}{ WSIS } \\
\hline & & & $\mathrm{CO}_{2}$ & $\mathrm{CO}$ & $\overline{\mathrm{H}_{2}}$ & $\overline{\mathrm{CH}_{4}}$ & $\mathrm{CO}_{2}$ & $\mathrm{CO}$ & $\overline{\mathrm{H}_{2}}$ & $\overline{\mathrm{CH}_{4}}$ & \\
\hline Glucose & 0.16 & 0.12 & 0.57 & 0.09 & 0.02 & 0.05 & 0.78 & 0.12 & 0.03 & 0.07 & + \\
\hline Fructose (p) & 0.18 & 0.13 & 0.62 & 0.14 & 0.10 & 0.03 & 0.70 & 0.15 & 0.11 & 0.04 & + \\
\hline Levoglucosan (p) & 0.18 & 0.12 & 0.58 & 0.13 & 0.07 & 0.00 & 0.74 & 0.17 & 0.09 & 0.00 & + \\
\hline Dihydroxyacetone (p) & 0.01 & 0.00 & 0.01 & 0.00 & 0.00 & 0.00 & 0.65 & 0.21 & 0.11 & 0.03 & + \\
\hline Erythrose (p) & 0.17 & 0.14 & 0.37 & 0.12 & 0.07 & 0.04 & 0.62 & 0.21 & 0.11 & 0.07 & + \\
\hline 5-Hmf (p) & 0.03 & 0.02 & 0.08 & 0.02 & 0.00 & 0.00 & 0.78 & 0.21 & 0.00 & 0.01 & + \\
\hline Furfural (p) & 0.12 & 0.06 & 0.22 & 0.05 & 0.04 & 0.01 & 0.69 & 0.17 & 0.11 & 0.04 & + \\
\hline Glyceraldehyde (p) & 0.22 & 0.16 & 0.40 & 0.07 & 0.10 & 0.01 & 0.69 & 0.12 & 0.17 & 0.02 & + \\
\hline Glycolaldehyde (p) & 0.21 & 0.16 & 0.24 & 0.08 & 0.02 & 0.00 & 0.70 & 0.22 & 0.07 & 0.01 & + \\
\hline Formaldehyde (p) & 0.48 & 0.35 & 0.29 & 0.06 & 0.10 & 0.00 & 0.65 & 0.13 & 0.22 & 0.00 & - \\
\hline Formic acid & 1.03 & 1.06 & 1.00 & 0.06 & 0.96 & 0.00 & 0.50 & 0.03 & 0.48 & 0.00 & - \\
\hline Levulinic acid & 0.02 & 0.01 & 0.04 & 0.00 & 0.00 & 0.00 & 1.00 & 0.00 & 0.00 & 0.00 & - \\
\hline Acetic acid & 0.05 & 0.04 & 0.05 & 0.01 & 0.00 & 0.02 & 0.63 & 0.13 & 0.00 & 0.03 & - \\
\hline Glycolic acid & 0.19 & 0.22 & 0.12 & 0.31 & 0.06 & 0.00 & 0.24 & 0.63 & 0.12 & 0.00 & - \\
\hline Lactic acid & 0.24 & 0.22 & 0.17 & 0.49 & 0.01 & 0.01 & 0.25 & 0.72 & 0.01 & 0.01 & - \\
\hline Acetone & 0.01 & 0.00 & 0.01 & 0.00 & 0.01 & 0.00 & 0.39 & 0.12 & 0.39 & 0.10 & - \\
\hline Acetaldehyde & 0.26 & 0.24 & 0.06 & 0.20 & 0.00 & 0.19 & 0.13 & 0.45 & 0.00 & 0.42 & - \\
\hline
\end{tabular}

Another possible source of gas is acetaldehyde, which produced significant amount of gas in our experiments even though it was reported to be stable toward hydrothermal gasification. ${ }^{23}$ Our results further show that, as expected, ${ }^{67}$ formic acid is completely converted to $\mathrm{CO}_{2}$ and $\mathrm{H}_{2}$ in a one to one molar ratio at $350{ }^{\circ} \mathrm{C}$ (see Table 2). Because $\mathrm{H}_{2}$ is hardly found in the gaseous product of glucose decomposition, formic acid cannot be the main gas-producing component in the decay of glucose in hot compressed water. It is unlikely that $\mathrm{H}_{2}$ formed in the decay of formic acid is consumed by reactions as this requires a catalyst under the applied conditions. ${ }^{68}$ This leads to the conclusion that selectivity of initial reactions toward formation of formic acid in the process is very low. 
Acetic acid, levulinic acid, and acetone hardly produce gas and can therefore also not be responsible for the gas production in the conversion of glucose. From other investigated secondary/tertiary decay products, lactic acid, glycolic acid, and acetaldehyde produce significant amounts of gas (see Table 2). The $\alpha$-carbonyl acids, lactic acid and glycolic acid, produce primarily $\mathrm{CO}$. This leaves only acetaldehyde as the possible main $\mathrm{CO}_{2}$ producing secondary/tertiary glucose HTC decomposition product.

Figure 3 shows that the formation of gas during the residence times from $1 \mathrm{~h}$ to 1 day. The WSIS product, which slowly produces gas at very long residence times, is the source of this gas (see below). However, from 1 day to 10 days residence time, no significant gas production was observed.

We are aware that by studying the decay products separately we excluded possible matrix effects that could occur during the conversion of glucose between the decay products. However, identifying these matrix effects would involve an enormous experimental effort, while the results of the individual decay products are indicative enough with respect to the production of gases and WSIS and already point out the complexity of the reaction path scheme.

\section{WSS + Water}

Figure 4 clearly shows that part of the WSS product is polymeric in nature having molecular masses of several thousands.

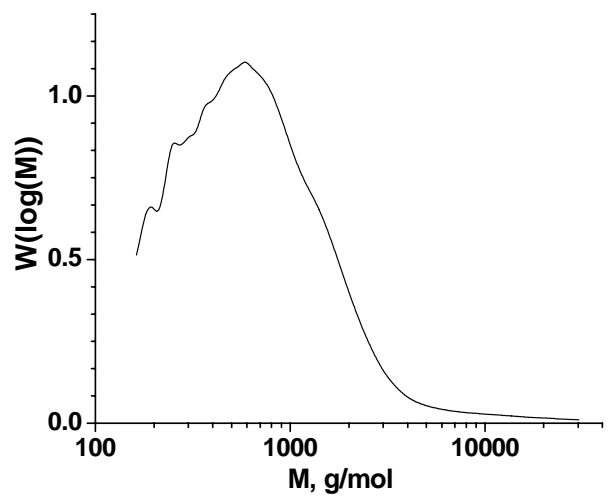

Figure 4. Molecular weight distribution of the WSS product. Conditions: $\tau=10 \mathrm{~min}, \mathrm{~T}^{\infty}=350^{\circ} \mathrm{C}$, $\mathrm{C}_{\mathrm{g}, 0}=88 \mathrm{~g} / \mathrm{L}$. The hot air oven was used. 
Figure 4 only shows molecular masses of 162 and up, because of the GPC calibration range. Especially at short residence times there are also components present with a molecular mass lower than $162 \mathrm{~g} / \mathrm{mol}$ in the WSS product, such as HMF and levoglucosan. ${ }^{43,46,47,49,65,70,71}$ These compounds can be detected by GC/MS. ${ }^{49}$

The weight average molecular weight (Mw) is in the range of 1050 to $1300 \mathrm{~g} / \mathrm{mol}$. This is in the same range as previously reported measurements of Luijkx. ${ }^{39}$ At the upper end of the spectrum, components with a molecular weight of up to $10000 \mathrm{~g} / \mathrm{mol}$ are detected by GPC. Hence, in hot compressed water the decay products of glucose undergo polycondensation reactions. The atomic composition of the WSS product expressed as the $\mathrm{H} / \mathrm{C}$ and $\mathrm{O} / \mathrm{C}$ ratio is plotted in Figure 5.

a)
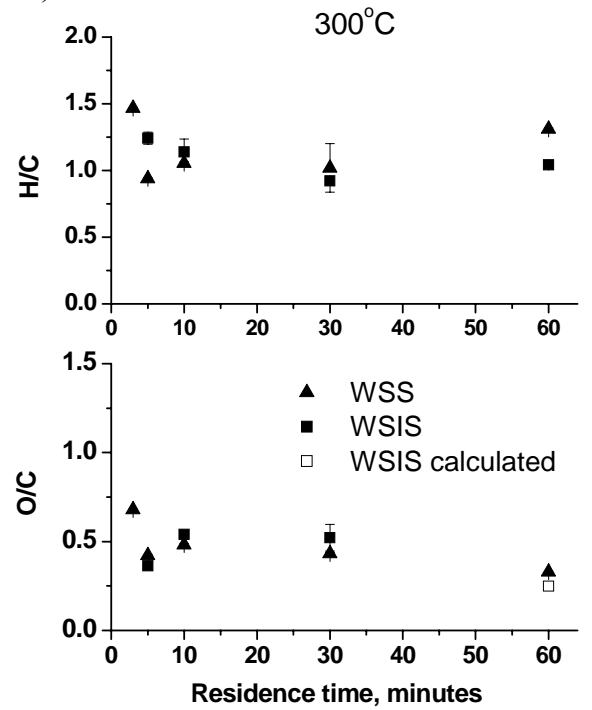

b)
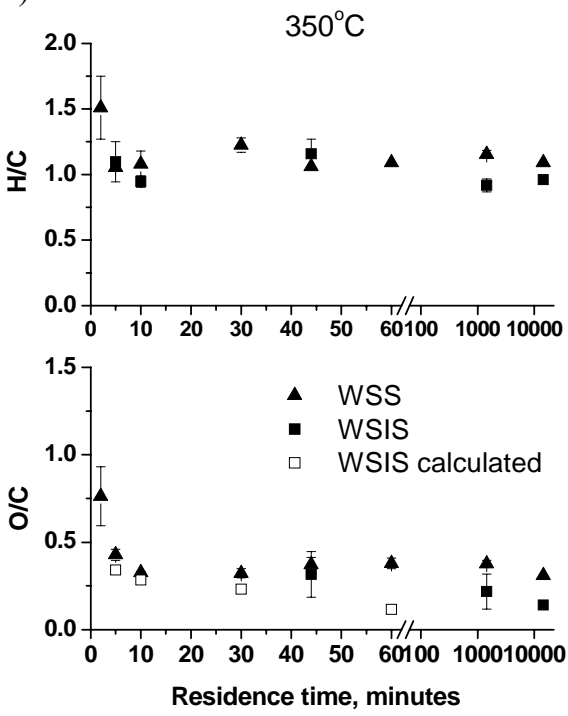

Figure 5. $\mathrm{H} / \mathrm{C}$ and $\mathrm{O} / \mathrm{C}$ of the WSS and WSIS product versus residence time. Conditions: $\mathrm{T}^{\infty}=300$ ${ }^{\circ} \mathrm{C}(\mathrm{a})$ and $350{ }^{\circ} \mathrm{C}(\mathrm{b}), \mathrm{C}_{\mathrm{g}, 0}=88 \mathrm{~g} / \mathrm{L}$. The hot air oven was used.

After short residence times, the composition of WSS is already different from glucose $(\mathrm{H} / \mathrm{C}$ $=2, \mathrm{O} / \mathrm{C}=1)$. This shows that it is not glucose itself that is undergoing polycondensation reactions to form WSS. In the first $5 \mathrm{~min}$ the $\mathrm{H} / \mathrm{C}$ and $\mathrm{O} / \mathrm{C}$ ratio of the WSS product decreases, which points to dehydration and decarboxylation reactions in the initial stages of the process. After $5 \mathrm{~min}$ of residence time, the atomic composition remains constant: at 350 ${ }^{\circ} \mathrm{C}, \mathrm{H} / \mathrm{C}=1.1 \pm 0.05$ and $\mathrm{O} / \mathrm{C}=0.37 \pm 0.05$ and at $300{ }^{\circ} \mathrm{C}, \mathrm{H} / \mathrm{C}=1.0 \pm 0.05$ and $\mathrm{O} / \mathrm{C}=$ $0.45 \pm 0.05$. On the basis of these numbers, the estimated Higher Heating Value of the WSS product is 26.4 and $22.7 \mathrm{MJ} / \mathrm{kg}$, at 350 and $300^{\circ} \mathrm{C}$, respectively. 
Compared to glucose the WSS product has considerably lower oxygen content $(\mathrm{O} / \mathrm{C}$ is 0.37 , for glucose it is 1). The accompanying lower $\mathrm{H} / \mathrm{C}$ of WSS compared to glucose ( $\mathrm{H} / \mathrm{C}$ is 1.1 , for glucose it is 2) indicates that deoxygenation proceeds primarily via dehydration reactions. This is in agreement with the (calculated) water yield (see Figure 3), which increases to a value of 0.30 ( 3 moles of $\mathrm{H}_{2} \mathrm{O}$ per mole of glucose). The water yield remains constant after the maximum WSS yield is reached. It is our hypothesis that in the decay of glucose, 3 moles of water per mol of glucose split off in the initial phase (e.g., in the reaction to $5-\mathrm{HMF}^{54}$ ) and that, thereafter, a part of the dehydrated decay product starts to polymerize to form the oligomer/polymer fraction of the WSS product and eventually WSIS product (see below). Because the atomic composition of WSS remains practically constant after 5 min residence time, the WSS product cannot be a source of gas production at residence times longer than $5 \mathrm{~min}$. If WSS would produce gas, the $\mathrm{O} / \mathrm{C}$ ratio of WSS should decrease because $\mathrm{CO}_{2}$ is the main gaseous product. This was confirmed by Matsumura et al. ${ }^{20}$ who showed by reprocessing WSS that WSS, once formed, no longer produces under hydrothermal conditions.

As mentioned before, a certain amount of stable WSS cannot be converted into other products. This fraction of the WSS product may consist partly of small water soluble decay products of glucose, which are stable under HTC conditions, such as acetic acid and levulinic acid (see Table 2).

\section{WSIS}

All primary decay products of glucose, except formaldehyde, produce WSIS product under the investigated conditions (see Table 2). The $\mathrm{H} / \mathrm{C}$ and $\mathrm{O} / \mathrm{C}$ ratios of WSIS show that, like WSS, WSIS is also a dehydrated product. At $350{ }^{\circ} \mathrm{C}$, the atomic composition of WSIS is $\mathrm{H} / \mathrm{C}=1.0$ and $\mathrm{O} / \mathrm{C}=0.3$, which resembles the composition of $\mathrm{HMF}$, one of the primary decay products. Model et al., ${ }^{69}$ Srokol et al., ${ }^{43}$ and Baugh et al. ${ }^{70,71}$ identified HMF as a component that can form stable poly aromatic structures that can lead to WSIS product formation. On the basis of the atomic composition, the estimated Higher Heating Value of the WSIS product is ca. $27 \mathrm{MJ} / \mathrm{kg}$ at $350{ }^{\circ} \mathrm{C}$.

As shown in the previous paragraph, the WSS product contains a fraction of molecules with very high molecular weight. It is known from precipitation theory in polycondensation ${ }^{72}$ that if molecules exceed a certain size, their solubility in solvents rapidly decreases. It is suggested here that actually WSS and WSIS are the same with respect to the chemical composition, with molecular weight being the only difference between them. The molecular weight of the WSIS product is, thus, too high for dissolution in acetone. This hypothesis is supported by the observations that, for residence times between 10 and $44 \mathrm{~min}$, the $\mathrm{H} / \mathrm{C}$ and $\mathrm{O} / \mathrm{C}$ composition of the WSS and WSIS product are, considering the scatter on the data, identical (see Figure 5). 
The molecular weight distribution of the WSS product implies that the maximum solubility of the polymerized product in acetone is ca. $10000 \mathrm{~g} / \mathrm{mol}$ because above $10000 \mathrm{~g} / \mathrm{mol}$ hardly any material is detected in the WSS product. In some publications ${ }^{70,71,73}$ the solid polymerized products, which form WSIS, are referred to as humins or humic acids.

For longer residence times, the O/C ratio of the WSIS product seems to decrease, though this decrease is not definite in view of the precision of these measurements. A decrease in $\mathrm{O} / \mathrm{C}$ ratio of WSIS would point toward a reaction of WSIS to gas $\left(\mathrm{CO}_{2}\right)$. To investigate the existence of this reaction, recovered WSIS product (after reaction at $350{ }^{\circ} \mathrm{C}$ for $10 \mathrm{~min}$ ) was reprocessed under $\mathrm{HTC}$ conditions $\left(350^{\circ} \mathrm{C}\right.$ for $1 \mathrm{~h}$ ). In these tests, 2 to $3 \%$ of the WSIS was converted into gas (mainly $\mathrm{CO}_{2}$ ) showing that WSIS can react to form $\mathrm{CO}_{2}$.

The formation of WSIS is clearly visualized in Figure 6, which shows snapshots of the events during the HTC of two glucose solutions of different concentrations at $350{ }^{\circ} \mathrm{C}$. The method used to make these snapshots is described in Knežević et al. ${ }^{50}$ After a certain time the solution turns brown, which indicates the formation of WSS. At a given time in the process, dark particles start to appear in the liquid phase. This product remains solid at room temperature and is insoluble in acetone (WSIS). Noticeably, the formation of WSIS starts earlier in higher concentration solution showing a higher reaction rate, which is typical for essentially second order polymerization reactions. This observation supports the assumptions derived from the theory and incorporated in our reaction model.

\section{Reaction Enthalpy}

From the yields and the composition of the products, the reaction enthalpy can be estimated with:

$$
\Delta H_{r}\left(25^{\circ} \mathrm{C}\right)=\sum_{i=\text { gas, WSS }, W S I S} Y_{i} \times H H V_{i}-H H V_{\text {glucose }}
$$

Only data points in the range of 10 to 60 min residence time were included in this analysis. In this range, the glucose conversion is complete. Filling in the equation gives $\Delta H_{r}\left(25^{\circ} \mathrm{C}\right)$ $=-1.5 \pm 0.5 \mathrm{MJ} / \mathrm{kg}$. There is no significant difference between the reaction enthalpies at 300 and $350{ }^{\circ} \mathrm{C}$. The reaction is exothermic meaning that the energetic yield to the products on HHV basis is less than one. In fact, in the range of 10 to $60 \mathrm{~min} 80$ to $85 \%$ of the HHV of glucose is transferred to the sum of the HHV's of the WSS and WSIS products.

Goudriaan et al. ${ }^{6}$ also determined the overall reaction enthalpy to be slightly less than zero. This was done by comparing the heating profile of the HTC reaction with the blank 
experiment (reactor containing only water). They also indicated two different reaction regimes: endothermic, which predominates in the beginning of the process, and exothermic, which is dominant at longer residence times (the turning point is not given in their work). This was not distinctly observed in our experiments due to the scatter in the data.

a)
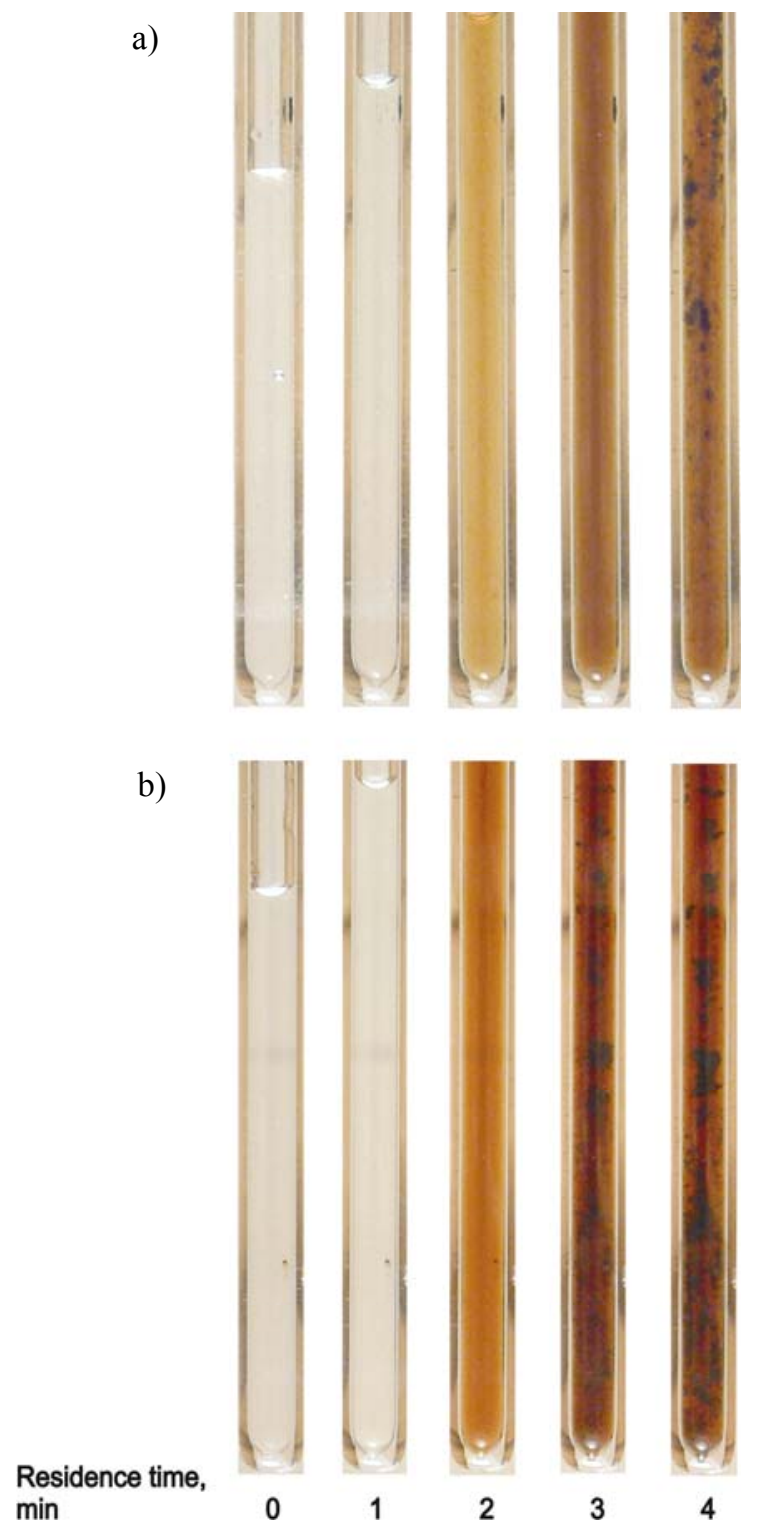

Figure 6. Snapshots of the content of a capillary under reaction conditions during HTC of glucose. Conditions: $\mathrm{T}^{\infty}=350^{\circ} \mathrm{C}$, (a) $\mathrm{C}_{\mathrm{g}, 0}=48 \mathrm{~g} / \mathrm{L}$ and (b) $\mathrm{C}_{\mathrm{g}, 0}=80 \mathrm{~g} / \mathrm{L}$. 


\section{Effect of the Initial Glucose Concentration on the Yields}

Figure 7 shows the effect of the initial glucose concentration on the yields.

a)

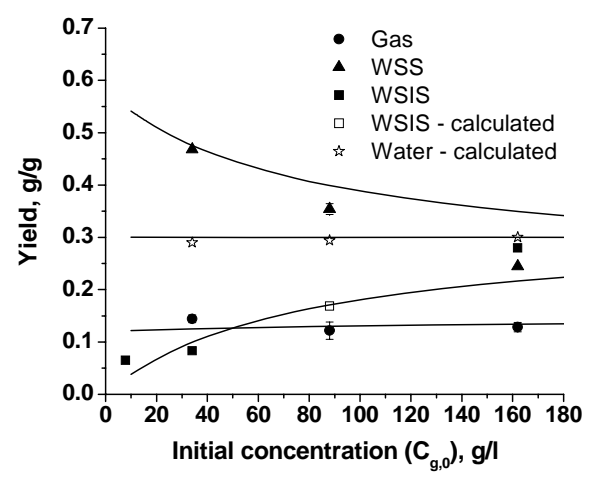

b)

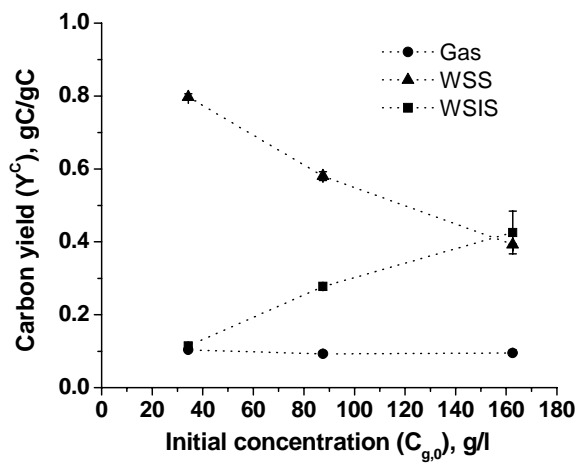

Figure 7. Yields (a) and carbon yields (b) of HTC of glucose versus concentration. Conditions: $\tau=10$ $\min , \mathrm{T}^{\infty}=350^{\circ} \mathrm{C}$. Full lines are model predictions (see section: Reaction path model and kinetics); dotted lines are trend lines. The hot air oven was used.

This figure shows that with increasing the initial glucose concentration, the WSS yield decreases and the WSIS yield increases, while the gas and water yields remain constant.

The decrease of the WSS yield with the increase in concentration was also reported by Eager and Mathews, ${ }^{9}$ Qu et al., ${ }^{37}$ and Borgund et al. ${ }^{74}$

The effect of the initial glucose concentration on the WSS and WSIS yield can be explained by the nature of the polycondensation reactions that form WSS and eventually WSIS product. These polycondensation reactions typically have a reaction order between 1 and 2 . In modeling work, 2 is often used (Smoluchowski equation ${ }^{75}$ ). When a certain fixed fraction of the initial decay products of glucose are converted into polymeric WSS and WSIS products via these second order reactions, a higher initial glucose concentration results in less WSS and more WSIS, under otherwise identical conditions, while assuming that the difference between WSS and WSIS is their molecular weight.

The observation that the gas yield is not affected by the initial glucose concentration indicates that a fraction of the initial decay products (e.g., water soluble WSS) is converted into gases via first-order reactions and that these gas forming reactions are not in competition (via parallel reactions) with the production of WSS and WSIS. If there were such competing reactions, an increase in initial glucose concentration would result in an increased WSIS and WSS yield and a decreased gas yield. The fact that water yield is not influenced by the initial glucose concentration supports our hypothesis that in the decay of 
glucose, 3 moles of water split off in the initial phase and that hereafter partly dehydrated decay products start to polymerize to WSS and WSIS product.

\section{Reaction Path Model and Kinetics}

The reaction path scheme of glucose to the primary decay products is reported by several researchers ${ }^{39,43,45-47,54,62,63,66,70,71}$ (see Figure 8a).

All primary products of glucose are soluble in water (WS). These products, in addition to water and gas formation, polymerize to form solvent soluble (SS) part of WSS products and also WSIS product. The present investigation has revealed that all primary decay products can form the polymeric WSIS product.

Following our hypothesis that WSIS and WSS are essentially the same products, with WSIS having a higher molecular weight, it can be reasoned that all primary products also produce polymeric WSS product. Gas is also produced from all primary decay products, although not with the same yield. This new information is included in the reaction path scheme shown in Figure 8a. Obviously this scheme is too complicated to find kinetics on the level of individual components and accompanying reactions. To obtain a workable model, lumping of reactions and components has been applied. We are aware of the pitfalls of using empirical lumped products, such as: dependence of the mixing state on the apparent reaction order, ${ }^{76}$ but for this case it is the only possibility to get a workable model for batch or plug flow reactors.

In the reaction path model, the product classification, as used in the experimental work, has been adapted. The lumped group gas represents permanent gases and consists primarily of $\mathrm{CO}_{2}$. WSIS is a product that does not dissolve in water and acetone and after drying and cooling is a solid. WSS includes water soluble components (e.g., anhydro-sugars and small acids/aldehydes/ketones) and acetone soluble components (including polymers of up to $10000 \mathrm{~g} / \mathrm{mol}$ ). The proposed lumped reaction path scheme is given in Figure 8b. For an additional description of the product groups and subgroups according to the model, see Appendix A. The reasoning behind this reaction path model is discussed point-wise hereafter:

- The composition of WSS and WSIS changes as a function of residence time (see Figure 5), indicating that in the model these lumped products can be composed of at least two subgroups. The composition of gas remains constant within the limits of the experimental technique (see Figure 3) and is, as a consequence, modeled by only one group.

- WSS and water are primary products while WSIS and gas are formed from WSS (see Figure 3 and Matsumura et al. ${ }^{20}$ ). These observations point toward an overall serial reaction scheme of glucose to WSIS and gas via WSS. 
- $\quad$ Our data clearly show that not all WSS is converted to gas and WSIS (see Figure 3) meaning that a part of the WSS product (WSS-D, see Figure $8 \mathrm{~b}$ ) does not react further. WSS-D may consist of small water soluble products that do not polymerize, nor form gases.

- Water is formed together with WSS and thereafter does not increase significantly (see Figure 3), at least for residence times less than $1 \mathrm{~h}$. Variation of the initial glucose concentration does not result in different water yields. These observations point toward initial water formation from glucose together with WSS product according to a first order reaction. This is in line with the measured glucose decomposition kinetics ${ }^{46,52-54}$ which show a reaction order of close to one.

- At relatively short residence times $(\tau=10 \mathrm{~min})$, varying the glucose concentration in the range of 34 to $162 \mathrm{~g} / \mathrm{L}$ does not result in a significant difference in gas yield (see Figure 7). Therefore there must be a route to gas that gives a gas yield (almost) independent of the glucose concentration. This route is described in the model by including a subgroup of WSS (WSS-A) that reacts with a first order reaction to gas. Contrary to the initial gas yield, increasing the glucose concentration in the range of 34 to $162 \mathrm{~g} / \mathrm{L}$ does result in a significant increase in WSIS yield (see Figure 7). This means that a reaction order of WSS to WSIS must be larger than one. In the model, the reaction order of WSS to WSIS is assumed to be 2 . However, as stated before, WSIS product, cannot be formed from WSS-A by a reaction parallel to the gas produced from WSS-A. If this would be the case, increasing the glucose concentration would lead to more WSIS and less gas, which is not observed experimentally.

- The WSIS production and WSS decay clearly have two rates: a fast rate in the first hour, followed by a much slower rate at longer residence times. This is modeled by incorporating a fast and a slow reaction of WSS to WSIS in the model, namely, WSS-B $\rightarrow$ WSIS-A and WSS-C $\rightarrow$ WSIS-A, respectively.

- While reprocessing WSIS it has been found that it is slowly converted to $\mathrm{CO}_{2}$. This is modeled by introducing a reaction of WSIS-A to gas and oxygen leaner WSIS (WSIS-B).

- The fact that after 5 min residence time, the atomic composition of WSS does not change shows that WSS only initially reacts to form gases $\left(\mathrm{CO}_{2}\right)$. Matsumura et $\mathrm{al}^{20}$ also found this by reprocessing WSS product. Hence, there is no further reaction of WSS to gas at residence times longer than $5 \mathrm{~min}$.

The model contains 11 parameters, which is too many to be fitted simultaneously to the limited amount of experimental data. In order to get sound fits for this scheme, the reactions should be fitted independently, which is not possible in this case. To obtain the model parameters another approach has been chosen here. The overall rate of glucose 
decomposition has been measured separately, which provides $k_{G}$. The stoichiometric constants: a, $\mathrm{d}$, e and $\mathrm{f}$ are obtained from the yields at infinite residence time (10 days) and at $10 \mathrm{~min}$ by assuming that all fast reactions are then completed. This reduced the number of parameters to 6 .

a)

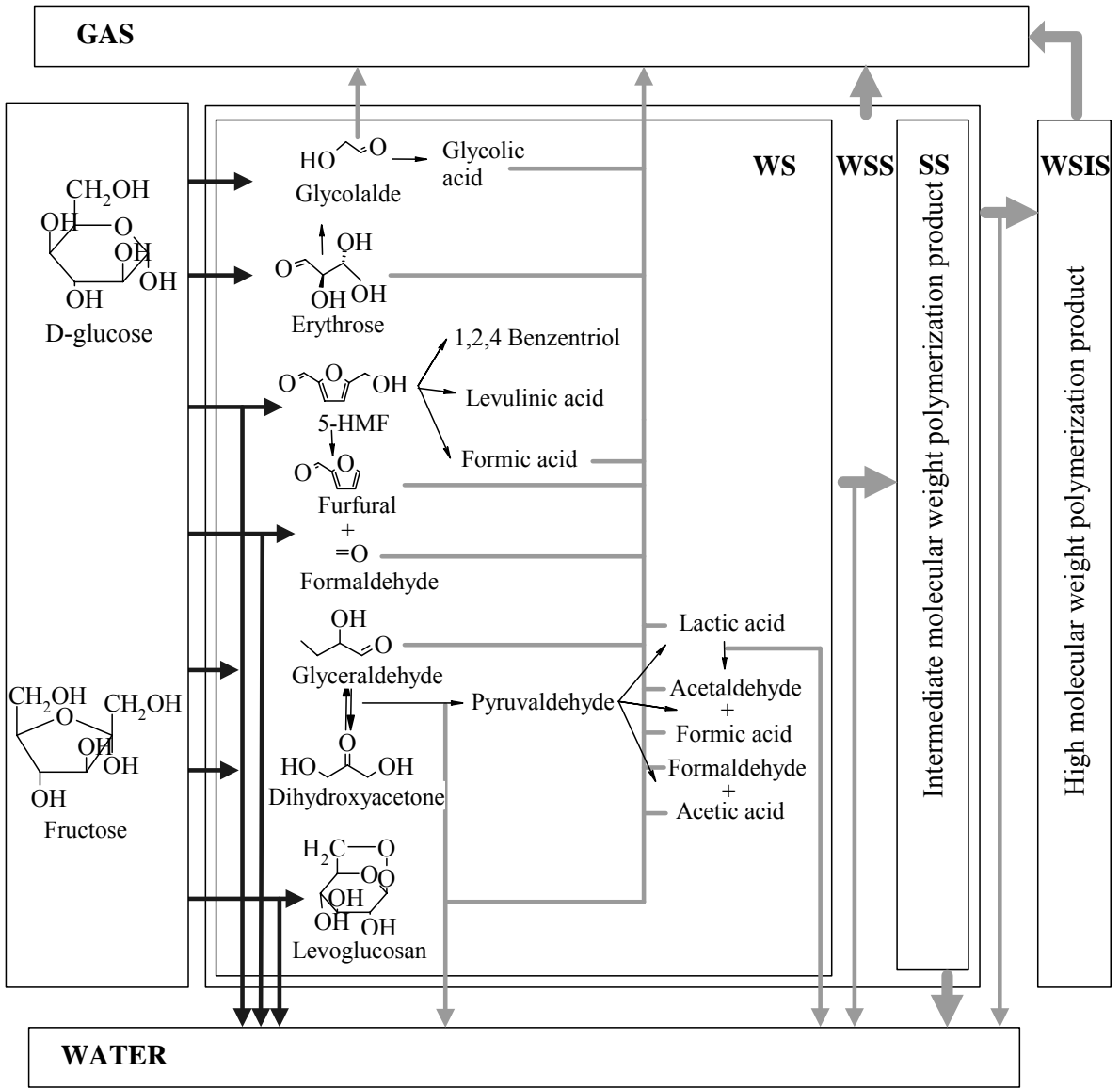

b)

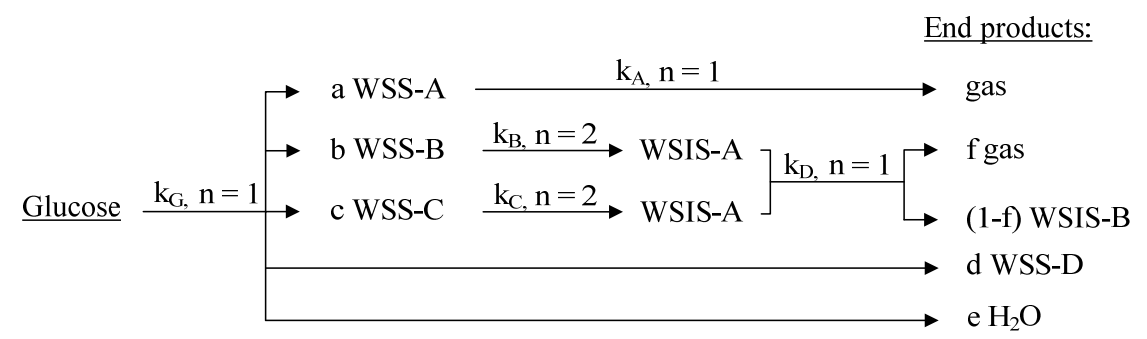

Figure 8. (a) Proposed reaction pathways and (b) formal reaction mechanism with kinetic parameters according to the model for HTC of glucose. 
The fitting procedure is described in Appendix A. Not too much importance has to be attributed to the numerical value of the model parameters given in Table 3; obviously they are correlated, nevertheless they show no erratic behavior. The fit procedure was merely preformed to check if indeed the proposed lumped reaction pathway model can predict the measured trends and approach a quantitative description. To get a more sound fit, more data are required, especially at more temperature levels.

Table 3. Stoichiometric and kinetic parameters for the lumped reaction path model

\begin{tabular}{ccc} 
parameter & $300{ }^{\circ} \mathrm{C}$ & $350{ }^{\circ} \mathrm{C}$ \\
\hline $\mathrm{a}$ & 0.1 & 0.12 \\
$\mathrm{~b}$ & 0.4 & 0.33 \\
$\mathrm{c}$ & 0.07 & 0.12 \\
$\mathrm{~d}$ & 0.13 & 0.13 \\
$\mathrm{e}$ & 0.3 & 0.3 \\
$\mathrm{f}$ & 0.35 & 0.35 \\
$\mathrm{k}_{\mathrm{G}}, \mathrm{s}^{-1}$ & see Table 1 & see Table 1 \\
$\mathrm{k}_{\mathrm{A}}, \mathrm{s}^{-1}$ & 0.0042 & 0.0108 \\
$\mathrm{k}_{\mathrm{B}}, \mathrm{g}^{-1} * \mathrm{~L}^{*} \mathrm{~s}^{-1}$ & 0.000083 & 0.000083 \\
$\mathrm{k}_{\mathrm{C}}, \mathrm{g}^{-1} * \mathrm{~L}^{*} \mathrm{~s}^{-1}$ & 0 & 0.0000033 \\
$\mathrm{k}_{\mathrm{D}}, \mathrm{s}^{-1}$ & 0.00025 & 0.00058
\end{tabular}

Model predictions in terms of total WSS, WSIS, and gas produced are plotted in the Figures 3 and 7. It can be concluded that the predictions of this model are rather good, especially when considering that the carbon balance of the experiments varies between 0.86 and 1.01 . The model includes all relevant trends/characteristics, especially for short residence times, such as: (i) water formed in the initial stages of the reaction and does not change significantly hereafter, (ii) the WSS yield goes through a maximum, (iii) the gas yield is independent of the initial glucose concentration, and (iv) WSIS (char) formation is fast and dependent on the initial glucose concentration with an order higher than 1 (in a certain time less char is formed in diluted systems).

\section{Conclusions}

Glucose has been used as model component to study the behavior of the sugar fraction of biomass during subcritical hydrothermal processing $\left(300-350{ }^{\circ} \mathrm{C}\right)$. Under these conditions, glucose decomposition can be described with sufficient accuracy by a first order reaction having activation energy of $114 \mathrm{~kJ} / \mathrm{mol}$. Water is formed in the first $5 \mathrm{~min}$ of residence 
time, and is not formed afterward. The formation rate of the products: gas, WSS (oil), and WSIS (char) is the highest during the first 5-10 $\mathrm{min}$, where after the rate becomes considerably slower. The main part of the gas $\left(\mathrm{CO}_{2}\right)$ and all of the water are formed in the initial stages of the decomposition. WSS was found to be a polymerized oily product with considerably lower oxygen content than glucose ( $\sim 30 \mathrm{wt} \%$ vs. $53 \mathrm{wt} \%)$. This translates to a minimum $50 \%$ increase in the energy density of WSS with respect to glucose (HHV glucose $=15.6 \mathrm{MJ} / \mathrm{kg}$ ). The WSS product is largely unstable and exhibits a maximum yield with respect to the residence time, as it reacts to gas and WSIS. Dehydration reactions contribute more to the deoxygenation than decarboxylation reactions (ca. 6 moles of water are formed per mole of $\mathrm{CO}_{2}$ at 5-10 min reaction time), leading to a low $\mathrm{H} / \mathrm{C}$ ratio $(\sim 1.1 \mathrm{vs.}$ 2 of glucose) of the WSS product. Yields of WSS and WSIS are affected by the glucose concentration: for relevant residence times of less than one hour, a higher concentration leads to less WSS and more WSIS. WSIS and WSS have nearly the same elemental composition indicating that the only essential difference between these products is the degree of polymerization. Hence, minimization of char formation during HTC can be achieved by operating at a low sugar concentration. It has been observed from separate dedicated experiments that the primary decay products of glucose also form gas and/or WSIS, showing that a detailed reaction path model based on all identified species would be too complex. Therefore, all observed phenomena are incorporated in a kinetic reaction path model with lumped products and intermediates, which describes the observed rates and yield trends correctly. 


\section{Appendix A: Explanation of Derivation of Kinetic Constants}

The calculation procedure is explained here for $350{ }^{\circ} \mathrm{C}$. It was assumed that the infinite yields (which were measured for $350{ }^{\circ} \mathrm{C}$ at 10 days residence time) were the same for 300 ${ }^{\circ} \mathrm{C}$, which is approximately true.

For developing the engineering reaction model, the following products of glucose decay were identified (see Figure $8 \mathrm{~b}$ ):

- WSS-A: WSS product that forms the initial gas (formic acid, formaldehyde...) in the first $10 \mathrm{~min}$ residence time. This reaction is assumed to be complete in this time and the gas yield measured after 10 min residence time determines the parameter $\mathbf{a}=0.12$;

- WSS-B: WSS product that quickly transforms to WSIS;

- WSS-C: WSS product that slowly transforms to WSIS; WSS-D: WSS product that is stable and does not change with residence time (WSS yield after 10 days: $\mathbf{d}=$ $0.13)$;

- $\quad \mathrm{H}_{2} \mathrm{O}$ : produced water $(\mathbf{e}=\mathbf{0 . 3})$;

- WSIS-A: WSIS product of WSS polymerization;

- WSIS-B: WSIS product left after gas formation from WSIS-A;

- Gas: gas yield. Gas is comprised of: quickly produced gas (from decomposition of WSS-A) and slowly produced gas from WSIS. From gas mass balance parameter $\mathbf{f}$ can be determined: $a+f^{*}(b+c)=Y_{\text {gas }}(10$ days $)$ $\rightarrow \mathrm{f}=\left(Y_{\text {gas }}(10\right.$ days $\left.)-\mathrm{a}\right) /(1-\mathrm{a}-\mathrm{d}-\mathrm{e})$.

- The rate of glucose decomposition is based on separate tests, and $k_{\mathrm{G}}$ is taken from Table 1.

By assuming these discrete values for the parameters mentioned the amount of variables to be fitted was reduced to six: $\mathrm{b}, \mathrm{c}, k_{\mathrm{A}}, k_{\mathrm{B}}, k_{\mathrm{C}}$, and $k_{\mathrm{D}}$. The fitting was done in MATLAB using the "fmincon" routine. The data of the time series (Figure 3) and the concentration series (Figure 7) were fitted simultaneously. It was assumed that all reactions proceeded at the end temperature, except for the decay of glucose itself, which included the heating trajectory according to eq. 9. The fitted model parameters are given in Table 3. 


\section{Notation}

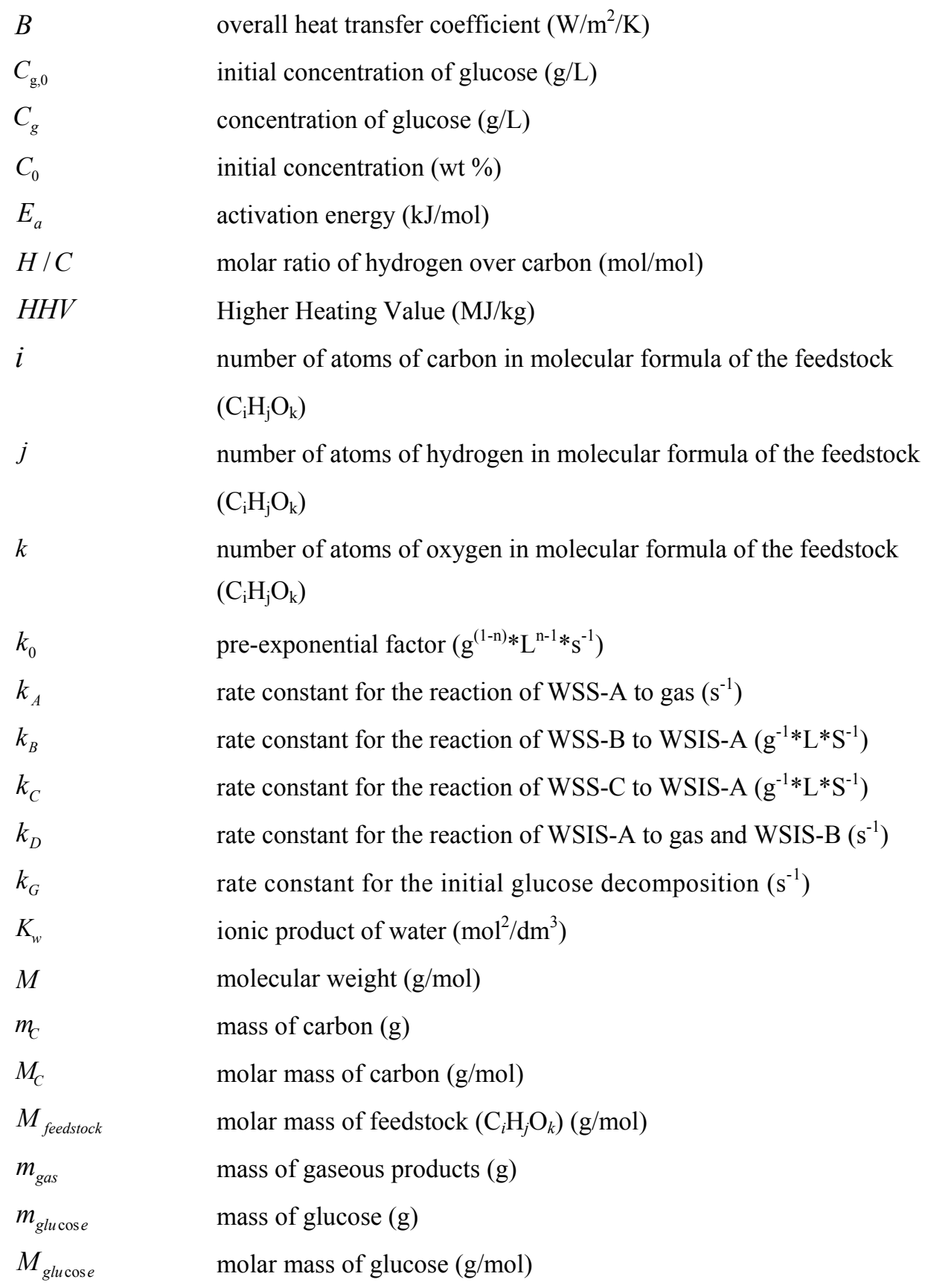




\begin{tabular}{|c|c|}
\hline$m_{g l u \cos e}$ in WSS & mass of non-reacted glucose in WSS (g) \\
\hline$m_{H}$ & mass of hydrogen (g) \\
\hline$M_{H}$ & molar mass of hydrogen $(\mathrm{g} / \mathrm{mol})$ \\
\hline$m_{O}$ & mass of oxygen $(\mathrm{g})$ \\
\hline$M_{O}$ & molar mass of oxygen $(\mathrm{g} / \mathrm{mol})$ \\
\hline$M_{W}$ & weight average molecular weight (g/mol) \\
\hline$m_{W S S}$ & mass of water-solvent soluble reaction product (g) \\
\hline$m_{W S I S}$ & mass of water-solvent insoluble reaction product $(\mathrm{g})$ \\
\hline$m_{\text {gas }}^{C}$ & mass of carbon in gaseous product $(\mathrm{g})$ \\
\hline$m_{g l u \cos e}^{C}$ & mass of carbon in glucose $(\mathrm{g})$ \\
\hline$m_{\text {glucose }}^{C}$ & mass of carbon in non-reacted glucose $(\mathrm{g})$ \\
\hline$m_{W S S}^{C}$ & mass of carbon in water-solvent soluble reaction product $(\mathrm{g})$ \\
\hline$m_{W S I S}^{C}$ & mass of carbon in water-solvent insoluble reaction product (g) \\
\hline$n$ & reaction order \\
\hline$O / C$ & molar ratio of oxygen over carbon $(\mathrm{mol} / \mathrm{mol})$ \\
\hline$R$ & universal gas constant $=8.314(\mathrm{~J} / \mathrm{mol} / \mathrm{K})$ \\
\hline$T$ & temperature $\left({ }^{\circ} \mathrm{C}\right)$ \\
\hline$T^{\infty}$ & preset temperature of the oven $\left({ }^{\circ} \mathrm{C}\right)$ \\
\hline$W(\log (M))$ & molecular weight distribution \\
\hline$X$ & conversion $(\mathrm{g} / \mathrm{g})$ \\
\hline$Y_{g a s}$ & yield of gaseous reaction products ( $\mathrm{g} / \mathrm{g}$ feedstock) \\
\hline$Y_{\mathrm{H}_{2} \mathrm{O}}$ & yield of water as the reaction product ( $\mathrm{g} / \mathrm{g}$ feedstock) \\
\hline$Y_{W S S}$ & yield of water-solvent soluble reaction product (g/g feedstock) \\
\hline$Y_{W S I S}$ & yield of water-solvent insoluble reaction product ( $\mathrm{g} / \mathrm{g}$ feedstock) \\
\hline$Y^{C}$ & cumulative carbon yield ( $\mathrm{g} \mathrm{C} / \mathrm{g} \mathrm{C}$ in feedstock) \\
\hline$Y_{\text {gas }}^{C}$ & carbon yield of gas ( $\mathrm{g} \mathrm{C/g} \mathrm{C}$ in feedstock) \\
\hline$Y_{g l u \cos e \text { in WSS }}^{C}$ & carbon yield of non-reacted glucose ( $\mathrm{g} \mathrm{C} / \mathrm{g} \mathrm{C}$ in glucose) \\
\hline$Y_{W S S}^{C}$ & $\begin{array}{l}\text { carbon yield of water-solvent soluble reaction product ( } \mathrm{g} \mathrm{C} / \mathrm{g} \mathrm{C} \text { in } \\
\text { feedstock) }\end{array}$ \\
\hline
\end{tabular}


$Y_{W S I S}^{C}$

carbon yield of water-solvent insoluble reaction product $(\mathrm{g} \mathrm{C} / \mathrm{g} \mathrm{C}$ in feedstock)

\section{Greek Letters}

$\begin{array}{ll}\Delta H_{r} & \text { reaction enthalpy }(\mathrm{MJ} / \mathrm{kg}) \\ \tau_{h} & \text { heating time (s, min) } \\ \tau & \text { total residence time (s, min) }\end{array}$




\section{References}

${ }^{1}$ Appell, H.R.; Fu, Y.C.; Friedman, S., Yavorsky, P.M.; Wender I. Converting organic wastes to oil: A replenishable Energy Source. Bureau of Mines Report of Investigations, 7560, 1971.

${ }^{2}$ Wilhelm, D. J; Kam, A.Y.; Stallings, J. W. Transportation fuel from biomass by direct liquefaction and hydrotreating. Symposium papers: Energy from biomass and wastes V, January 26-30, 1981, Lake Buena Vista, Florida, USA, p.651-686

${ }^{3}$ Annee, J. H. J.; Ruyter, H. P. Process for Producing Hydrocarbon containing Liquids from Biomass. European patent number: 0204354, 1986.

${ }^{4}$ Yokoyama, S-Y.; Ogi,T.; Kogushi, K. Process for liquefying cellulose containing biomass. US patent number: 4935567, Jun 19, 1990.

${ }^{5}$ Goudriaan, F.; Peferoen, D. G. R. Liquid fuels form biomass via a hydrothermal process. Chem. Eng. Sci. 1990, 45, 2729.

${ }^{6}$ Goudriaan, F.; Van de Beld, B.; Boerefijn, F. R.; Bos, G. M.; Naber, J. E.; Van der Wal, S.; Zeevalkink, J. A. Thermal efficiency of the HTU Process for biomass liquefaction. In Proceedings of the conference: Progress in Themochemical Biomass Conversion; Bridgwater, A. V., Ed.; Blackwell Science: England, 2000; pp 1312.

${ }^{7}$ Molton, M.P.; Fassbender, A.G.; Robertus, R.R.; Brown, M.D.; Sullivan, R.G. Thermochemical conversion of primary sewage sludge by STORS process. In Research in Thermochemical Biomass Conversion; Bridgwater A.V., Ed.; Kuester J.L., Ed.; Elsevier Applied Science, 1988; pp 867-882.

${ }^{8}$ Boocock, D. G. B.; Porretta, F. Physical Aspects of the Liquefaction of Poplar Chips By Rapid Aqueous Thermolysis. Journal of wood chemistry and technology 1986, 6(1), 127.

${ }^{9}$ Eager, R.L.; Mathews, J.F.; Pepper, J.M. Liquefaction of aspen poplar to produce oil and chemicals. In Fundamentals in thermochemical biomass conversion, R.P. Overend, Ed.; Milne T., Ed.; L. Mudge., Ed.; Springer, 1985; pp. 1051-1071.

${ }^{10}$ Boocock, D.G.B.; Sherman, K.M. Further Aspects of Powdered Poplar Wood Liquefaction by Aqueous Pyrolysis. Can. J. Chem. Eng. 1985, 63, 627.

${ }^{11}$ Beckman, D.; Boocock, D.G. Liquefaction of Wood by Rapid Hydropyrolysis. Can. J. Chem. Eng. 1983, 61,80 .

${ }^{12}$ White D.H., Wolf D. Direct biomass liquefaction by an extruder-feeder system. Chem. Eng. Comm. 1995, 135,1 .

${ }^{13}$ Modell, M; Reid, RC; Amin S. Gasification process. US Patent number: 4113446. September 1978.

${ }^{14}$ Antal, M. J. Jr.; Allen, S.G.; Schulman, D.; Xu, X.; Divilio, R.J. Biomass Gasification in Supercritical Water. Ind. Eng. Chem. Res. 2000, 39, 4040.

${ }^{15}$ Elliott, D. C.; Silva, L. J. The TEES process cleans waste and produces energy. Presented at the $R$ 1995 Conference, Geneva, Switzerland, 1-3 Feb. 1995.

${ }^{16}$ Elliott, D. C; Phelps, M.R.; Sealock Jr., L. J.; Baker, E. G. Chemical Processing in Hot Pressure Aqueous Environments. 4. Continuous-Flow Reactor Process Development Experiments for Organics Destruction. Ind. Eng. Chem. Res. 1994, 33, 566. 
${ }^{17}$ Elliott, D.C.; Neuenschwander, G. G.; Hart, T.R.; Butner, R. S.; Zacher, A. H.; Engelhard, M.H.; Young, J. S.; McCready, D. E.Chemical Processing in High-Pressure Aqueous Environments. 7. Process Development for Catalytic Gasification of Wet Biomass Feedstocks. Ind. Eng. Chem. Res. 2004, 43, 1999.

${ }^{18}$ Hashaikeh, R.; Butler, I. S.; Kozinski, J. A. Selective Promotion of Catalytic Reactions during Biomass Gasification to Hydrogen. Energy \& Fuels 2006, 20, 2743.

${ }^{19}$ Schmieder, H; Abeln, J.; Boukis, N.; Dinjus, E.; Kruse, A.; Kluth, M.; Petrich, G.; Sadri, E.; Schacht M. Hydrothermal gasification of biomass and organic wastes. Journal of Supercritical Fluids 2000, 17, 145.

${ }^{20}$ Matsumura, Y.; Minowa, T.; Potic, B.; Kersten, S. R. A.; Prins, W.; van Swaaij, W. P. M.; van de Beld, B.; Elliott, D. C.; Neuenschwander, G. G.; Kruse, A.; Antal, M. J., Jr. Biomass Gasification In Near- And Super-Critical Water: Status And Prospects. Biomass Bioenergy 2005, 29, 269.

${ }^{21}$ Williams, P. T.; Onwudili, J. Subcritical and Supercritical Water Gasification of Cellulose, Starch, Glucose, and Biomass Waste. Energy \& Fuels 2006, 20, 1259.

${ }^{22}$ Kruse A.; Gawlik, A. Biomass Conversion in Water at 330-410 C and 30-50 MPa. Identification of Key Compounds for Indication of Different Chemical Reaction Pathways. Ind. Eng. Chem. Res. 2003, 42, 267.

${ }^{23}$ Waldner, M. H.; Vogel, F. Renewable production of methane from woody biomass by catalytic hydrothermal gasification. Ind. Eng. Chem. Res. 2005, 44, 4543.

${ }^{24}$ Kersten, S. R. A; Potic, B.; Prins, W.; Van Swaaij, W.P.M. Gasification of Model Compounds and Wood in Hot Compressed Water. Ind. Eng. Chem. Res. 2006, 45, 4169.

${ }^{25}$ Kersten, S. R. A.; Prins, W.; Van Swaaij, W. P. M. Reactor Design Considerations for Biomass Gasification in Hot Compressed Water. In Proceedings of the 2nd World Conference and Technology Exhibition on Biomass for Energy, Industry and Climate Protection; Van Swaaij, W. P. M., Ed.; Fjalistrom, T., Ed.; Helm, P., Ed.; Grassi, A., Ed.; ETA-Florence and WIP-Munich: Rome, Italy, 2004; p 1062.

${ }^{26}$ Van Rossum, G.; Kersten, S. R. A.; van Swaaij, W. P. M. Catalytic and Noncatalytic Gasification of Pyrolysis Oil. Ind. Eng. Chem. Res. 2007, 46, 3959.

${ }^{27}$ Dickinson N.L. Pollutant free low temperature combustion process having carbonaceous fuel suspended in aqueous alkaline solution. US patent number 4241722, Dec 30, 1980.

${ }^{28}$ Dickinson N.L. Pollutant free pressurized fluidized bed combustion utilizing a high concentration of water vapor. US patent number 4292953, Oct 6, 1981.

${ }^{29}$ Dickinson N.L. Pollutant free low temperature slurry combustion process utilizing supercritical state. US patent number 4377066, Mar 22, 1983.

${ }^{30}$ Dickinson N.L. Combination of supercritical wet combustion and compressed air energy storage. US patent number 4593202, Jun 3, 1986.

${ }^{31}$ Dickinson N.L. Pollutant free pressurized combustion utilizing a controlled concentration of water vapor. US patent number 4714032, Dec 22, 1987.

${ }^{32}$ Dickinson N.L. Pressurized wet combustion of wastes in the vapor phase. US patent number 4898107, Feb 6, 1990. 
${ }^{33}$ Akiya, N.; Savage, P. E.; Roles of Water for Chemical Reactions in High- Temperature Water. Chem. Rev. 2002, 102, 2725.

${ }^{34}$ Kritzer, P. Corrosion in high-temperature and supercritical water and aqueous solutions: a review. Journal of Supercritical Fluids 2004, 29, 1.

${ }^{35}$ Potic, B.; Kersten, S. R. A.; Prins, W.; Assink, D.; Van de Beld, L.; Van Swaaij, W. P. M. Gasification of Biomass in Supercritical Water: Results of Micro and Pilot Scale Experiments. In Proceedings of the 2nd World Conference and Technology Exhibition on Biomass for Energy, Industry and Climate Protection; Van Swaaij, W. P. M., Ed.; Fjalistrom, T., Ed.; Helm, P., Ed.; Grassi, A., Ed.; ETA-Florence and WIP-Munich: Rome, Italy, 2004; p 742.

${ }^{36}$ Jenkins, B.M.; Baxter, L.L.; Miles Jr. T.R.; Miles, T.R. Combustion properties of biomass. Fuel Processing Technology 1998, 54, 17.

${ }^{37} \mathrm{Qu}, \mathrm{Y}$;; Wei, X.; Zhong, C. Experimental study on the direct liquefaction of Cunninghamia lanceolata in water. Energy, 2003, 28, 597.

${ }^{38}$ Krochta, J.M.; Hudson, J.S.; Drake, C.W.; Mon, T.R.; Pavlath, A.E. Thermal Degradation Of Cellulose in Alkali. In: Fundamentals of Thermochemical Biomass Conversion: An International Conference, Estes Park Colorado, 1985, pp. 1073.

${ }^{39}$ Luijkx G.C.A. Hydrothermal conversion of carbohydrates and related compounds, $\mathrm{PhD}$ thesis Technical University Delft 1994.

${ }^{40}$ Deglise, X.; Mason, D.; Kafrouni, H.; Ladousse, A. Wood Liquefaction: total mass and energy balances. In Energy from Biomass and Wastes III; Palz, W., Ed.; Coombs, J., Ed.; Hall, D.O., Ed.; Elsevier Applied Science Publishers, 1985; pp. 920.

${ }^{41}$ Minowa, T.; Kondo, T.; Sudirjo, S. T. Thermochemical liquefaction of Indonesian Biomass Residues. Biomass \& Bioenergy 1998, 14, 517.

${ }^{42}$ Yang, Y. F.; Feng, C. P.; Inamorib, Y.; Maekawa, T. Analysis of energy conversion characteristics in liquefaction of algae. Resources, Conservation and Recycling 2004, 43, 21.

${ }^{43}$ Srokol, Z.; Bouche,A-G; van Estrik, A; Strik, R. C. J.; Maschmeyer, T. Peters, J.A. Hydrothermal upgrading of biomass to biofuel; studies on some monosaccharide model compounds. Carbohydrate Research 2004, 339, 1717.

${ }^{44}$ Adshiri, T.; Hirose, S.; Malaluan, R; Arai, K. Noncatalytic conversion of cellulose in supercritical and subcritical water. J. of Chem. Eng. of Japan 1993, 26, 676.

${ }^{45}$ Khajavi, S.H.; Kimura, Y; Oomori, T.; Matsuno, R; Adachi, S. Degradation kinetics of monosaccharides in subcritical water. Journal of Food Engineering 2005, 68, 309.

${ }^{46}$ Kabayemela, B.M.; Adshiri, T.; Malaluan, R.M.; Arai, K. Kinetics of glucose epimerization and decomposition in subcritical and supercritical water. Ind. Eng. Chem. Res. 1997, 36, 1552.

${ }^{47}$ Kabayemela, B.M., Adshiri, T.; Malaluan, R.M.; Arai, K. Glucose and fructose decomposition in supercritical and subcritical water: detailed reaction pathways, mechanisms, and kinetics. Ind. Eng. Chem. Res. 1999, 38, 2888.

${ }^{48}$ Kersten, S. R. A.; Van Swaaij, W. P. M.; Lefferts, L.; Seshan, K. Options for Catalysis in the Thermochemical Conversion of Biomass into Fuels. In Catalysis for Renewables: From Feedstock to Energy Production, Centi, G., Ed.; Van Santen, R. A., Ed.; Wiley, John \& Sons, Incorporated, 2007; pp 119. 
${ }^{49}$ Knežević, D; Schmiedl, D.; Meier, D.; Kersten, S.; Van Swaaij, W. High-Throughput Screening Technique for Conversion in Hot Compressed Water: Quantification and Characterization of Liquid and Solid Products. Ind. Eng. Chem. Res. 2007, 46, 1810.

${ }^{50}$ Knežević, D.; Rep, M.; Kersten, S. R. A.; Prins, W.; Van Swaaij, W. P. M. Hydrothermal liquefaction and pyrolysis: A visualization study. In Science in Thermal and Chemical Biomass Conversion, Victoria, Canada; Bridgwater, A. V., Ed.; Boocock, D. G. B., Ed.; CPL Press, 2006; pp.1082.

${ }^{51}$ Domelski, E.S.; Jobe Jr.; T.L.; Milne, T A. Thermochemical data for biomass conversion and waste incineration. A product of solar technical information program prepared by the National Bureau of Standards under contract t o t h e Solar Technical Information Program of the Solar Energy Research Institute, 1986.

${ }^{52}$ Bobleter. O; Pape, G. Der hydrothermale Abbau von Glucose. Monatshefte fiir Chemie 1968, 99, 1560 .

${ }^{53}$ Matsumura,Y.; Yanachi, S.; Yoshida, T. Glucose Decomposition Kinetics in Water at $25 \mathrm{MPa}$ in the Temperature Range of 448-673 K. Ind. Eng. Chem. Res. 2006, 45, 1875.

${ }^{54}$ Amin, S.; Reid, R. C.; Modell, M. Reforming and Decomposition of Glucose in an Aqueous Phase. Intersociety Conference on Environmental Systems, San Francisco, CA, 1975; The American Society of Mechanical Engineers (ASME): New York, 1975; ASME Paper No. 75-ENAs-21.

${ }^{55}$ Sakaki, T.; Shibata, M; Miki, T.; Hirosue, H.; Hayashi, N. Reaction model of cellulose decomposition in near-critical water and fermentation of the products. Bioresource technology 1996, 58, 197.

${ }^{56}$ Minowa, T.; Fang, Z.; Ogi, T.; Várhegyi, G. Decomposition of Cellulose in Hot-Compressed Water under Catalyst-Free Conditions. J. of Chem. Eng. of Japan 1998, 31, 131.

${ }^{57}$ Várhegyi, G; Szabó, P.; Mok; W. S. L.; Antal, Jr, M. J. Kinetics of the thermal decomposition of cellulose in sealed vessels at elevated pressures: effects of the presence of water on the reaction mechanism. Journal of Analytical and Applied Pyrolysis 2001, 57, 203.

${ }^{58}$ Holgate, H. R.; Meyer, J. C.; Tester, J. W. Glucose Hydrolysis and Oxidation in Supercritical Water. AIChE J. 1995, 41, 637.

${ }^{59}$ Sakaki, M.; Kabayemela, B.; Malaluan, R.; Hirose, S.; Takeda, N. Adschiri, T.; Arai, K. Cellulose hydrolysis in subcritical and supercritical water. J Supercritical Fluids 1998, 13, 261.

${ }^{60}$ Sakaki, T.; Shibata, M; Sumi, T.; Yasuda, S. Saccharification of cellulose using a hot-compressed water-flow reactor. Ind. Eng. Chem. Res. 2002, 41, 661.

${ }^{61}$ Bobleter, O; Bonn, G. The hydrothermolysis of cellobiose and its reaction product D-glucose. Carbohydrate research 1983, 124, 185.

${ }^{62}$ Aida, T.M.; Tajima, K.; Watanabe, M.; Saito, Y.; Kuroda, K.; Nonaka, T.; Hattori, H.; Smith Jr., R. L.; Arai, K. Reactions of d-fructose in water at temperatures up to $400{ }^{\circ} \mathrm{C}$ and pressures up to 100MPa. J. of Supercritical Fluids 2007, 42, 110.

${ }^{63}$ Aida, T.M; Sato, Y.; Watanabe, M; Tajima, K.; Nonaka, T.; Hattori, H; Arai, K. Dehydration of dglucose in high temperature water at pressures up to 80MPa. J. of Supercritical Fluids 2007, 40, 381. 
${ }^{64}$ Sinag, A.; Kruse, A.; Rathert, J. Influence of the Heating Rate and the Type of Catalyst on the Formation of Key Intermediates and on the Generation of Gases During Hydropyrolysis of Glucose in Supercritical Water in a Batch Reactor. Ind. Eng. Chem. Res. 2004, 43, 502.

${ }^{65}$ Fang, Z.; Minowa, T.; Smith, Jr., R. L.; Ogi, T. Kozinski, J. A. Liquefaction and Gasification of Cellulose with $\mathrm{Na} 2 \mathrm{CO} 3$ and $\mathrm{Ni}$ in Subcritical Water at $350{ }^{\circ} \mathrm{C}$. Ind. Eng. Chem. Res. 2004, 43, 2454.

${ }^{66}$ Watanabe, M.; Aizawa, Y.; Iida, T.; Levy, C.; Aida, T.M; Inomata, H.; Glucose reactions within the heating period and the effect of heating rate on the reactions in hot compressed water. Carbohydrate Research 2005, 340, 1931.

${ }^{67}$ Yu, J.; Savage, P. E. Decomposition of Formic Acid under Hydrothermal Conditions. Ind. Eng. Chem. Res. 1998, 37, 2.

${ }^{68}$ Elliott, D. C. Historical Developments in Hydroprocessing Bio-oils. Energy \& Fuels 2007, 21, 1792.

${ }^{69}$ Modell, M. Gasification and Liquefaction of Forest Products is Supercritical Water. In Fundamentals of Thermochemical Biomass Conversion; Overend R.P., Ed.; Milne T .A., Ed.; Mudge L.K., , Ed.; Elsevier Applied Science, 1985; pp.95-119.

${ }^{70}$ Baush, K; McCarty, P. Thermochemical Pretreatment of Lignocellulose to Enhance Methane Fermentation: I. Monosaccharide and Furfurals Hydrothermal Decomposition and Product Formation Rates. Biotechnology and Bioengineering 1988, 31, 50.

${ }^{71}$ Baugh, K.D.; Levy, J.A. ; McCarty, P.L. Thermochemical pretreatment of lignocellulose to enhance methane fermentation. II. Evaluation and application of pretreatment model. Biotechnol. Bioeng. Symp. 1988, 31, 62.

${ }^{72}$ Wolf B.A. Solubility of polymers. Pure \& Appl Chem. 1985, 57, 323.

${ }^{73}$ Girisuta, B.; Janssen, L. P. B. M.; Heeres, H. J. Green chemicals: A Kinetic Study on the Conversion of Glucose to Levulinic Acid. Chemical Engineering Research and Design 2006, 84, 339.

${ }^{74}$ Borgund, A.E.; Barth T. Effects of base catalysis on the product distribution from pyrolysis of woody biomass in the presence of water. Organic Geochemistry 1999, 30, 1517.

${ }^{75}$ Irzhak, V. I. Methods of description of polycondensation kinetics and the structures of the polymers formed. Russian Chemical Reviews 1997, 66, 541.

${ }^{76}$ Koetsier, W. T.; Pniak, B.; Boegborn E.; Van Swaaij, W. P. M. The reaction rate constant distribution function for hydrodesulfurization of gas-oil, Proc. CHISA '81, Prague, 1981. 


\title{
CHAPTER 4
}

\section{Hydrothermal Conversion of Biomass - Part II: Conversion of Wood, Pyrolysis Oil and Glucose in Hot Compressed Water}

\begin{abstract}
In part I of this work, hydrothermal conversion (HTC) of glucose has been studied. In this part II of the study, the investigation is extended to two other feedstocks: wood and pyrolysis oil. The effects of residence time (0-60 min) and feedstock concentration (0-45 wt \%) on product yields are investigated at $350^{\circ} \mathrm{C}$. For all three investigated feedstocks: i) oil, char, gas are formed with two distinct rates (fast rates in the first 10 min followed by slow rates after this time), ii) deoxygenation proceeds via both dehydration and decarboxylation. Dehydration is an initial reaction (first $5 \mathrm{~min}$ ) and leads to undesired lowering of the H/C ratio of the oil product. Two types of char have clearly been identified for HTC of wood: primary char (non-liquefied remainder of biomass) and secondary char (polymerization product). Only a small amount of primary char is formed, while at longer residence times, typically practiced in pilot and demonstration plants, the majority of char is produced in polymerization reactions in the liquid phase (reaction order $>1$ ). Several catalysts have been tested for their ability to increase decarboxylation and reduce char formation. The Ru/TiO ${ }_{2}$ catalyst is able to convert char to gas, while leaving the oil product practically unaltered with respect to composition and yield. Visual observations have revealed that a single liquid phase appears to exist at the HTC reaction conditions, and that phase splitting into an oil and a water phase occurs in the temperature range of $180-220^{\circ} \mathrm{C}$. The engineering reaction path model, proposed for glucose in part I of this work, is extended for use with solid biomass and pyrolysis oil.
\end{abstract}




\section{Introduction}

This is a part II of the investigation of hydrothermal conversion (HTC) of biomass using batch quartz capillary reactors. ${ }^{1,2}$ Part I introduced the experimental methods used and results of glucose, as a model component for the sugar fraction of lignocellulosic biomass, were presented. In part II, wood and pyrolysis oil are considered as feedstock for HTC. Like in part I, the effects of reaction time and concentration of the organic material in the feedstock on the product yields and the reaction rate, are investigated. Similarities and differences between the feedstocks used: glucose, wood and pyrolysis oil, are discussed. Several catalysts are screened with respect to enhanced deoxygenation and char minimization. The influence of water on the decomposition process is investigated by comparing HTC of wood with (dry) pyrolysis of wood. Phase behavior under reaction conditions, of interest for the reactor design, is studied by visualization. As mentioned before (part I), after cooling down the reactor effluent, a hydrophobic and a hydrophilic phase are present next to a gas phase. By direct visualization of the reaction medium in the quartz capillaries it is investigated whether or not mixing of the oil and water phase occurs under reactor conditions.

In the section "Discussion and Conclusion", all findings of part I and part II are united as a basis for an evaluation of hydrothermal processing. Herein the following items are addressed: i) oil product quality: deoxygenation level and molecular weight, ii) char formation and ways to minimize this, and iii) the role of catalysis.

\section{Experimental}

\section{Experimental Methods and Analysis}

In this study the earlier developed batch quartz capillary technique was used. Below a short description of this technique is given. For details the reader is referred to Potic et al., ${ }^{1}$ Knežević et al. ${ }^{2-4}$ Quartz capillaries of $d_{i n}=0.002 \mathrm{~m}$ and $\mathrm{L}=0.15 \mathrm{~m}$ were charged with feedstock and, in most cases, water. The capillaries were then sealed by melting and placed in an oven. In all the experiments presented here, a hot air oven was used. The heating time of the capillaries in this system was $140 \mathrm{~s}$. Reported residence times $(\tau)$ include this heating time. The pressure in the capillaries under the HTC process conditions was estimated from the known water vapor pressure and the produced gases. Mixing of the 
catalysts and the feed was induced by shaking the capillary with a pneumatic piston. In case slurry feed was used, several glass particles were added in order to facilitate the mixing in the non-catalytic experiments. After cooling, three product phases were present in a capillary: a gaseous phase consisting mainly of $\mathrm{CO}_{2}$, an aqueous phase containing organics dissolved (WS), and a hydrophobic phase. The hydrophobic phase contained acetone soluble (oil) and acetone insoluble (char) components. Solvent (acetone) extraction was used for the workup of the condensed products. In the separation process, organics soluble in water and acetone formed a separate phase: Water-Solvent-Soluble phase (WSS) also called oil, which was collected as filtrate. The residue of the recovery procedure (collected as a filter cake) consisted of the Water-Solvent-InSoluble (WSIS) product, also called char. After drying and removal of acetone, the yields of WSS and WSIS were determined gravimetrically and these products were analyzed by GPC, GC/MS and CHN elemental analysis. Gas production was measured by breaking the capillaries in a chamber with a know volume and temperature. From the increase in pressure and GC analysis of the chamber's content after breaking the individual gas productions could be calculated.

Water production was calculated from the elemental balances. In some cases, for which recovery of the WSIS product was troublesome, the values for WSIS yields were also calculated from the elemental balances. ${ }^{4}$ In the figures presented in this chapter it is always indicated if yields are directly measured or calculated from the elemental balances.

For visual observation at the reaction conditions the hot air oven was equipped with a loophole and artificial light. ${ }^{2}$ The capillaries were placed in the oven and photographs were taken at regular time intervals.

Pyrolysis experiments were conducted in the same closed capillaries (under $\mathrm{N}_{2}$ atmosphere). For these tests no water was added to the capillaries.

\section{Definitions of WSS and WSIS Products}

In part I of this work $^{4}$ we were able to determine the amount of the non-converted glucose in the WSS product and to correct the WSS yield and composition accordingly. Here this is not possible because the amounts of non-converted wood and pyrolysis oil can not be quantified by known methods. Non-converted wood, primary char (the solid remainder from pyrolysis) and large fragments from wood decomposition will be recovered in the WSIS phase. Hence, in case of wood, the WSIS phase can, next to the reaction products, also contain the unconverted reactants.

In the conversion of solid biomass like wood, the WSIS phase has two origins. Part of the WSIS phase consists of the unconverted solid structure of the feed. This part is called primary char. The rest of the WSIS is formed as a result of polymerization/ polycondensation reactions of components in the WSS phase and is called secondary char. ${ }^{3}$ The secondary char can be formed and stay within the primary char. 
For the conversion tests of pyrolysis oil, the situation is different. Since pyrolysis oil dissolves completely in acetone, unconverted pyrolysis oil components will be present in the WSS phase.

In our work on glucose, ${ }^{4}$ feedstock concentrations were expressed in grams of glucose per liter of solution. However, this approach is not suitable for suspensions and emulsions. Therefore, all yields and feedstock concentrations $\left(\mathrm{C}_{0}\right)$ are presented here as weight percentages of the organics in the feedstock. In case of pyrolysis oil experiments, the whole oil was charged into the capillaries and a given amount of water was added. The concentration of organics in pure pyrolysis oil was $76.1 \mathrm{wt} \%$ (see Table 1).

\section{Materials and Catalysts}

The materials used as feedstocks are given in Table 1. Sawdust from beech wood with a very low moisture content $<0.3 \mathrm{wt} \%$ and an average particle size of ca. 200 microns was used. Pyrolysis oil used was produced from Pihlava pine wood at ca. $500{ }^{\circ} \mathrm{C}$ and supplied by VTT, Finland. The oil was filtered prior to the experiments over a 10 micron glass filters in order to remove any residual char particles. For visualization experiments wood shreds were used (toothpick slices with thickness of ca $0.2 \mathrm{~mm}$ ).

Table 1. Elemental composition and water content of glucose, wood sawdust and pyrolysis oil (wt \% as received).

\begin{tabular}{lcccc} 
& $\mathrm{C}$ & $\mathrm{H}$ & $\mathrm{O}^{\text {a }}$ & $\mathrm{H}_{2} \mathrm{O}$ \\
& wt $\%$ & wt \% & wt \% & wt \% \\
\hline Glucose (powder) & 40 & 6.7 & 53.3 & 0 \\
Sawdust (particle diameter $\sim 0.2 \mathrm{~mm})$ & 45.6 & 5.5 & 48.9 & $<0.3$ \\
Pyrolysis oil (Pihlava pine) & 40.6 & 7.6 & 51.76 & 23.9
\end{tabular}

${ }^{\mathrm{a}}$ by difference

A list of homogeneous and heterogeneous catalysts used in this study is given in Table 2 . These catalysts were selected for their reported deoxygenation and cracking activity. Catalyst performance was screened by evaluating enhanced $\mathrm{CO}_{2}$ production (decarboxylation). It has been found that addition of $\mathrm{Ru} / \mathrm{TiO}_{2}$ catalyst enhances $\mathrm{CO}_{2}$ production second best (see section Catalytic Experiments). $\mathrm{Ru} / \mathrm{C}$ gives somewhat more $\mathrm{CO}_{2}$ production, but this catalyst could cause problems in the mass balance evaluation (carrier can be gasified). Therefore, $\mathrm{Ru} / \mathrm{TiO}_{2}$ catalyst was used to obtain full mass balances and product composition information for wood and glucose under catalytic conditions. The resulting gas yields will be discussed in the section Catalytic Experiments. 
Table 2. Lists of catalysts used and the gas yields of HTC of pyrolysis oil experiments. ${ }^{a}$

\begin{tabular}{|c|c|c|c|c|c|c|c|}
\hline \multirow{2}{*}{$\begin{array}{l}\text { Catalyst } \\
\mathrm{CuCl}_{2}\end{array}$} & \multirow{2}{*}{$\begin{array}{l}\text { Description } \\
\text { loride (>97\%) (Riedel-de }\end{array}$} & \multicolumn{2}{|c|}{$\begin{array}{l}\text { Solubility in water } \\
\mathrm{g} / 100 \mathrm{~g}^{\mathrm{g}} \text { water }^{5}\end{array}$} & \multicolumn{3}{|c|}{$\begin{array}{l}Y_{\mathrm{CO}_{2}} Y_{\mathrm{CO}} Y_{\mathrm{H}_{2}} \\
\text { wt \% wt \% wt \% }\end{array}$} & $\begin{array}{l}Y_{\mathrm{CH}_{4}} \\
\text { wt \% }\end{array}$ \\
\hline & & 70.7 & 107.9 & 7.0 & 0.5 & 0.0 & 0.0 \\
\hline $\mathrm{CuSO}_{4}$ & Copper(II) sulfate (>99\%) (Fluka) & 14.3 & 75.4 & 6.5 & 1.3 & 0.0 & 0.0 \\
\hline $\mathrm{Na}_{2} \mathrm{SO}_{4}$ & Sodium sulfate (>99\%) (Sigma-Aldrich ) & 19.4 & 45.3 & 7.6 & 0.5 & 0.0 & 0.0 \\
\hline $\mathrm{NaCl}$ & Sodium chloride $(>99.5 \%)$ (Fluka) & 35.7 & 39.8 & 8.2 & 0.9 & 0.0 & 0.0 \\
\hline $\mathrm{NiCl}$ & Nickel(II) chloride (Aldrich) & 53.8 & 87.6 & 3.4 & 0.3 & 0.0 & 0.0 \\
\hline $\mathrm{NiSO}_{4}$ & $\begin{array}{l}\text { Nickel(II) sulfate: anhydrous (99.99\%) } \\
\text { (Aldrich) }\end{array}$ & 27.2 & 76.7 & 8.0 & 0.5 & 0.0 & 0.0 \\
\hline $\mathrm{MoO}_{3}$ & $\begin{array}{l}\text { Molybdenum(VI) oxide ( } \geq 99.5 \% \text { ) (Sigma- } \\
\text { Aldrich) }\end{array}$ & 0.107 & 2.106 & 12.9 & 1.1 & 0.0 & 0.0 \\
\hline $\mathrm{TiO}_{2}$ & $\begin{array}{l}\text { Titanium(IV) oxide: technical ( } \geq 99 \% \text { ) } \\
\text { (Sigma-Aldrich) }\end{array}$ & heterogenec & us catalyst & 10.8 & 1.2 & 0.0 & 0.0 \\
\hline $\mathrm{ZrO}_{2}$ & $\begin{array}{l}\text { Zirconium(IV) oxide: purum ( } \geq 99 \%) \\
\text { (Sigma-Aldrich) }\end{array}$ & heterogenec & us catalyst & 10.2 & 1.1 & 0.0 & 0.0 \\
\hline $\mathrm{CuO}$ & $\begin{array}{l}\text { Copper(II) oxide: ACS reagent ( } \geq 99.0 \% \text { ) } \\
\text { (Sigma-Aldrich) }\end{array}$ & heterogenec & us catalyst & 12.5 & 1.0 & 0.1 & 0.0 \\
\hline $\mathrm{Ru} / \mathrm{TiO}_{2}$ & $\begin{array}{l}\text { Ruthenium (3\%) on titania (95\% rutile) } \\
\text { (Degussa) }\end{array}$ & heterogenec & us catalyst & 13.5 & 0.3 & 0.0 & 0.1 \\
\hline $\mathrm{Ru} / \mathrm{Al}_{2} \mathrm{O}_{3}$ & Ruthenium $(0.5 \%)$ on alumina (Aldrich ) & heterogenec & us catalyst & 12.3 & 0.6 & 0.0 & 0.0 \\
\hline $\mathrm{Ru} / \mathrm{C}$ & Ruthenium (5\%) on carbon (Aldrich) & heterogenec & us catalyst & 13.9 & 0.5 & 0.0 & 0.0 \\
\hline $\begin{array}{l}\text { Without } \\
\text { catalyst }^{\text {b }}\end{array}$ & - & - & & 8.6 & 0.6 & 0.0 & 0.0 \\
\hline
\end{tabular}

\section{Results}

In the following paragraphs only results of the tests with high carbon recovery are included (at least $91 \%$ for wood and pyrolysis oil, and at least $86 \%$ for glucose). Relative standard deviations ( $\sigma /$ mean) of repetitive experiments with wood and pyrolysis oil are, like with glucose ${ }^{4}$ ca. 0.1 , which is accurate enough for trend detection. 


\section{The Effect of Temperature on $\mathrm{CO}_{2}$ Split-off}

One of the reported advantages of HTC is the significant removal of oxygen via decarboxylation, which is, from energetic point of view, the optimal way of deoxygenation. The gas produced consists for more than $70 \%$ out of $\mathrm{CO}_{2}$ (see Table 2).

The $\mathrm{CO}_{2}$ yields at 30 min residence time for the three feedstocks studied are shown in Figure 1. Results at $30 \mathrm{~min}$ residence time are selected because in this time span, the relatively fast reactions to gas are completed, at least for temperatures of $250^{\circ} \mathrm{C}$ and above. Gas formation does continue after $30 \mathrm{~min}$, but with a very low rate. ${ }^{4}$

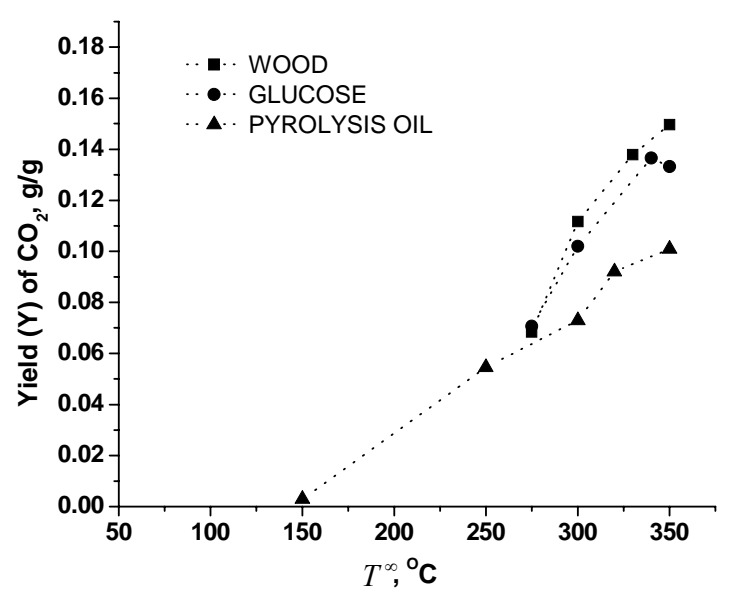

Figure 1. $\mathrm{CO}_{2}$ yields (measured) of HTC of wood, pyrolysis oil and glucose versus temperature.

Conditions: $\tau=30 \mathrm{~min} ; \mathrm{C}_{0}=9 \mathrm{wt} \%$ (glucose), $10-15 \mathrm{wt} \%$ (wood), $76.1 \mathrm{wt} \%$ (pyrolysis oil); $\mathrm{p}=$ 166 - 225 bar.

Different concentrations of feedstocks are used. It has been shown, however, that the concentration has no effect on the gas yields (see section Effect of the Feedstock Concentration at $\tau=10 \mathrm{~min}$ and $350{ }^{\circ} \mathrm{C}$ ) which is why the results can be presented together.

It can be seen that for all three feedstocks the $\mathrm{CO}_{2}$ yield increases with temperature and that decarboxylation of pyrolysis oil and its decay products starts to proceed at ca. $150^{\circ} \mathrm{C}$. This does not imply that $\mathrm{HTC}$ reactions do not occur below $150{ }^{\circ} \mathrm{C}$. The literature on biomass pretreatment shows that at such low temperatures many reactions are proceeding. ${ }^{6,7}$ However, below $150{ }^{\circ} \mathrm{C}$ these reactions have low rates and produce liquid products whose further reaction to gases is apparently very slow. For wood and pyrolysis oil no visual change of the feedstock is observed below $150^{\circ} \mathrm{C}$. 
The $\mathrm{CO}_{2}$ yield from pyrolysis oil is the lowest for all temperatures. This difference with the other feedstocks is the highest at $350^{\circ} \mathrm{C}$ and may be explained by the fact that already quite some $\mathrm{CO}_{2}$ is removed from the biomass during the fast pyrolysis process $\left(Y_{\mathrm{CO}_{2}} \sim 0.11 \mathrm{~g} / \mathrm{g}\right.$ of dry wood for fast pyrolysis at $350{ }^{\circ} \mathrm{C}^{8}$ ).

The $\mathrm{CO}_{2}$ yields of wood and glucose are similar, although the $\mathrm{CO}_{2}$ yield of wood is typically slightly higher. $\mathrm{CO}_{2}$ yields at $350{ }^{\circ} \mathrm{C}$ correspond to an oxygen removal via decarboxylation of $R_{\mathrm{CO}_{2}}=17.5,12.1$, and $18.2 \%$ for wood, pyrolysis oil and glucose, respectively.

\section{The Effect of Residence Time on the Yields at $350{ }^{\circ} \mathrm{C}$}

In Figure 2 product yields and carbon yields of HTC of all feedstocks used are given. The concentrations of organics in the feedstocks are not equal, which makes comparison of WSS and WSIS yields between the different feedstocks impossible because these yields depend on the concentration (see Figure 3). Gas and water yields do not depend on the feedstock concentration. However, trends in all product yields as function of the residence time can be compared.

To allow for comparison between wet and dry conversion, the carbon yields of $\operatorname{char}\left(Y_{W S I S}^{C}\right)$ and gas $\left(Y_{\text {gas }}^{C}\right.$ ) of pyrolysis of wood at $350{ }^{\circ} \mathrm{C}$ are also shown in Figure 2. As stated the previous paragraph, HTC gas yields of wood and glucose are higher than that of pyrolysis oil and these differences may be caused by the amount of gas already released in the pyrolysis process. With wood as feedstock nearly the same amount of gas is produced in the pyrolysis process as in HTC (see Figure 2c, $Y^{C}$ ) indicating that the presence of water does not significantly affect gas forming reactions. This observation points towards a thermal nature of gas production under both dry pyrolysis and hydrothermal conditions.

For all tested feedstocks, all the water is formed in the first 5 min of HTC (see Figure 2d). Glucose has the highest water yields $(\mathrm{Y}=0.30 \mathrm{~g} / \mathrm{g})$ and the water yields of wood and pyrolysis oil are comparable $(\mathrm{Y}=0.15 \mathrm{~g} / \mathrm{g})$. The lower water yield of wood and pyrolysis oil compared to glucose may be caused by water consuming reactions such as hydrolysis in the decomposition of wood and pyrolysis oil and possibly because from these feedstocks less water is produced anyway.

On basis of the gas and water yields, the ratio of oxygen removal via dehydration over oxygen removal via decarboxylation $(D)$ can be calculated. For $350{ }^{\circ} \mathrm{C}$ and $60 \mathrm{~min}$ the values of this ratio are: $1.25,1.19$ and 2.61 for wood, pyrolysis oil and glucose, respectively. This shows that for glucose the main deoxygenation mechanism is dehydration and that for wood and pyrolysis oil oxygen is removed only slightly more via 
dehydration compared to decarboxylation. The WSIS yield vs. residence time curve of wood HTC clearly shows two regimes (Figure $2 b$ ), namely:

i) dissolution of wood in water in the first $5 \mathrm{~min}$ (shown from the decrease in WSIS yield in the first minutes; remember that unconverted wood is recovered in WSIS) leading to a low value of primary char,

ii) formation of secondary char from the dissolved wood fragments causing the increase of the total amount of char at $\tau>5 \mathrm{~min}$.

The presence of liquid water has a clear effect on the char (WSIS) yield of wood HTC. This becomes clear when comparing WSIS yields from wood pyrolysis and HTC: the WSIS yield of HTC of wood is ca. 3 times lower at $\tau \geq 10$ min than the char yield of pyrolysis at the same temperature (see Figure $2 \mathrm{~b}-Y^{C}$ ).

Like in the case of glucose, when the yields are corrected for unconverted feedstock, the oil (WSS) yield of wood goes through a maximum $(\tau=3-5 \mathrm{~min})$ as a function of residence time. The downhill side of the curve is in both cases caused by the formation of secondary char out of WSS components. Because pyrolysis oil dissolves in the used solvent (acetone), the oil yield of pyrolysis oil decreases monotonically.

Remarkably, the rates of product formation are comparable for all feedstocks: a fast reaction takes place in the first $10 \mathrm{~min}$, followed by a much slower reaction at longer residence time.

\section{Effect of the Feedstock Concentration at $350{ }^{\circ} \mathrm{C}$ and $\tau=10 \mathrm{~min}$}

The effect of feedstock concentrations on the yields at $350{ }^{\circ} \mathrm{C}$ and a residence time of 10 min are shown in Figure 3. For all three feedstocks the WSS yield decreases and the WSIS yield increases with increasing feedstock concentration. This is ascribed to the higher order ( $>1$ ) polycondensation/polymerization reactions that convert WSS components into WSIS. $^{4}$

The yields of water and gas do not dependent on the feedstock concentration. In our opinion it is remarkable that these trends are identical for all three feedstocks as their molecular structure is rather different. The WSS yields of glucose and wood are nearly identical, while the WSS yield of pyrolysis oil is clearly the highest of the three feedstocks. During HTC of pyrolysis oil, less char is formed than with the other two feedstocks. Like the low gas formation, also the lower char yield of HTC of pyrolysis oil could be explained by the considerable amount of char already separated in the pyrolysis process. 
a) WSS
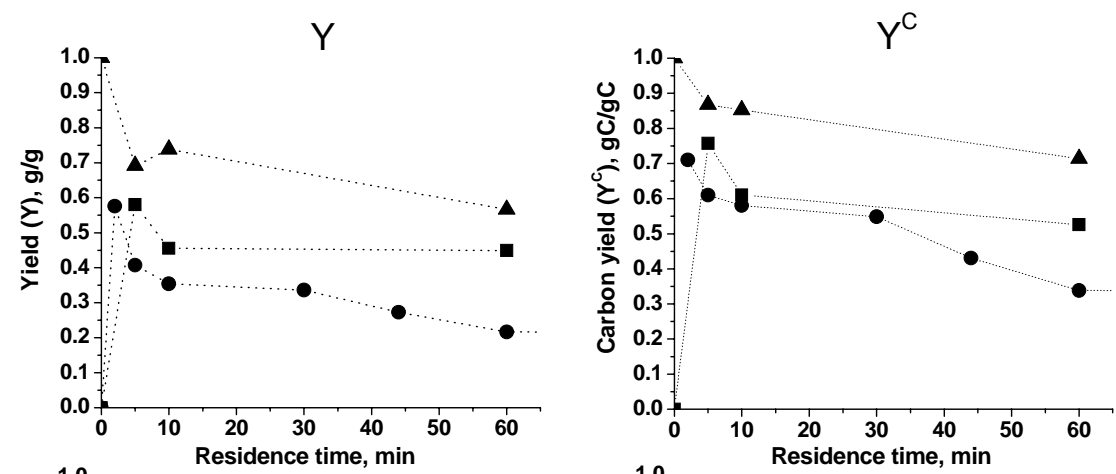

b) WSIS
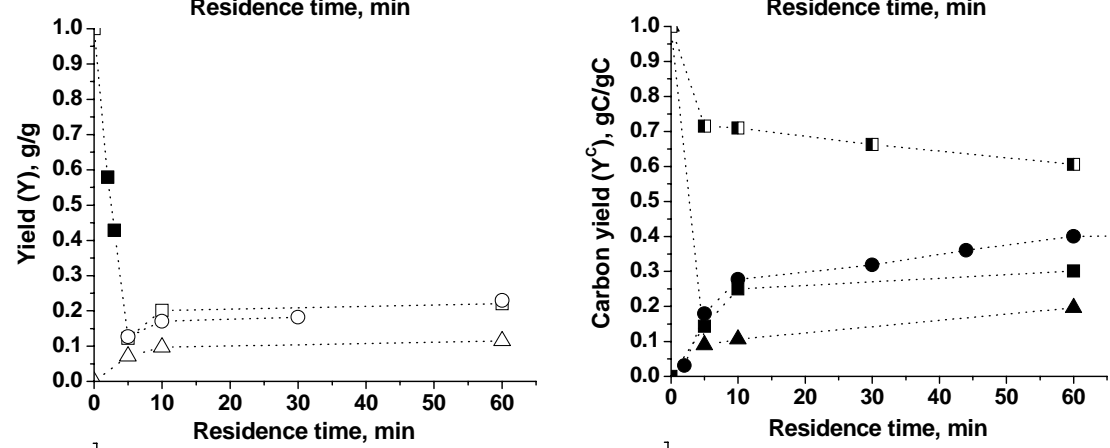

c) gas
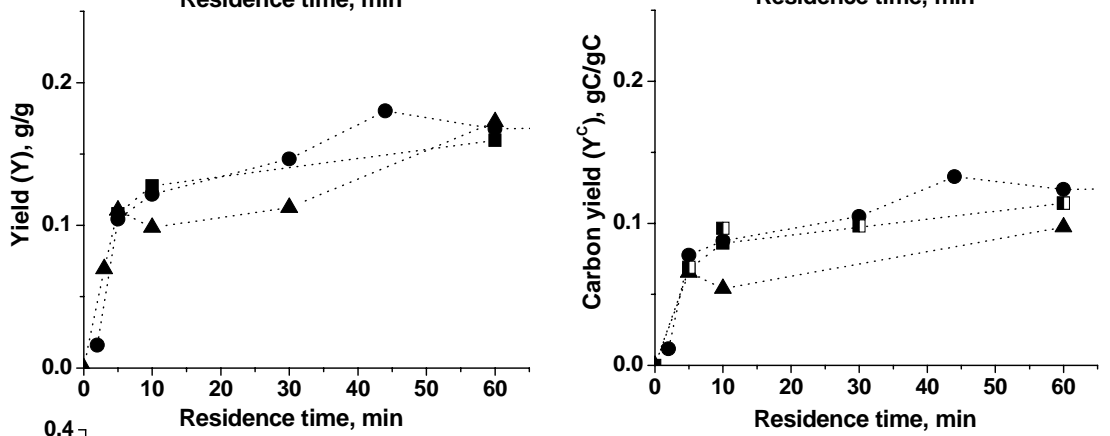

d) water

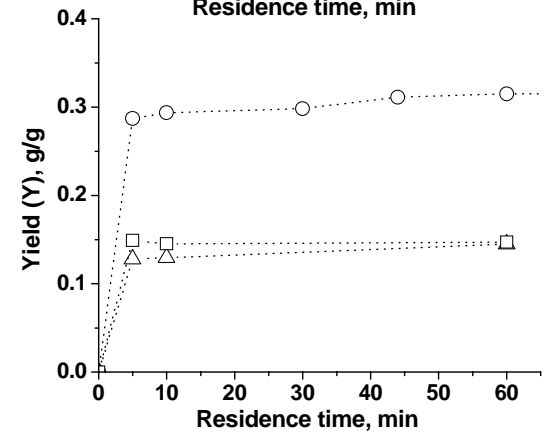

A. PYROLYSIS OIL (HTC)

-. GLUCOSE (HTC)

-.. WOOD (HTC)

WOOD (PYROLYSIS)

Figure 2. Yields and carbon yields of HTC of: wood, pyrolysis oil and glucose; and carbon yields of pyrolysis of wood versus residence time. Conditions: HTC: $T^{\infty}=350{ }^{\circ} \mathrm{C}, \mathrm{C}_{0}=3.6 \mathrm{wt} \%$ (wood), $6.7 \mathrm{wt} \%$ (pyrolysis oil), $8.8 \mathrm{wt} \%$ (glucose), $\mathrm{p}=166-170$ bar; pyrolysis: $T^{\infty}=350{ }^{\circ} \mathrm{C}, \mathrm{p}=1.5-5$ bar. Solid symbols are measured HTC data, open symbols are calculated HTC yields from the elemental balances, half solid symbols are the pyrolysis data. 
a) WSS
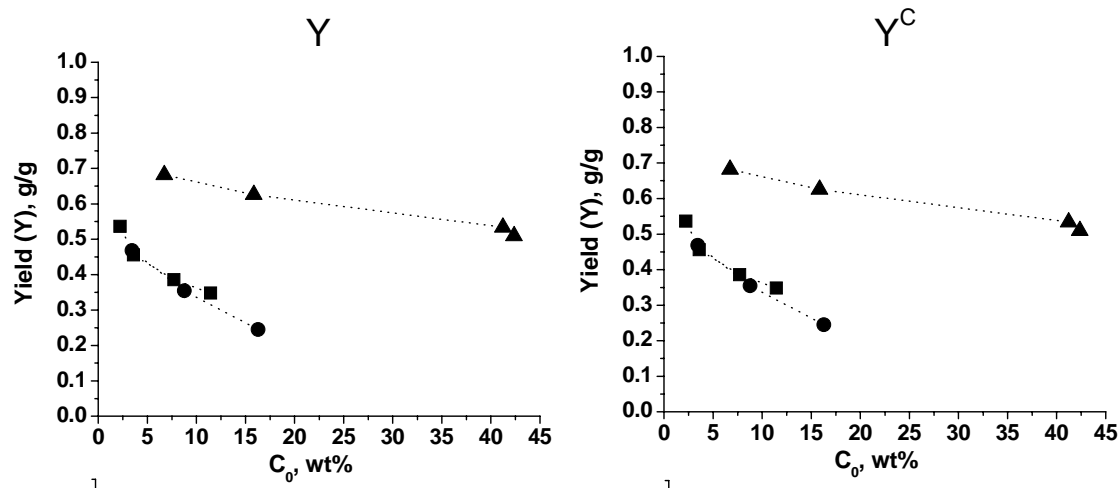

b) WSIS
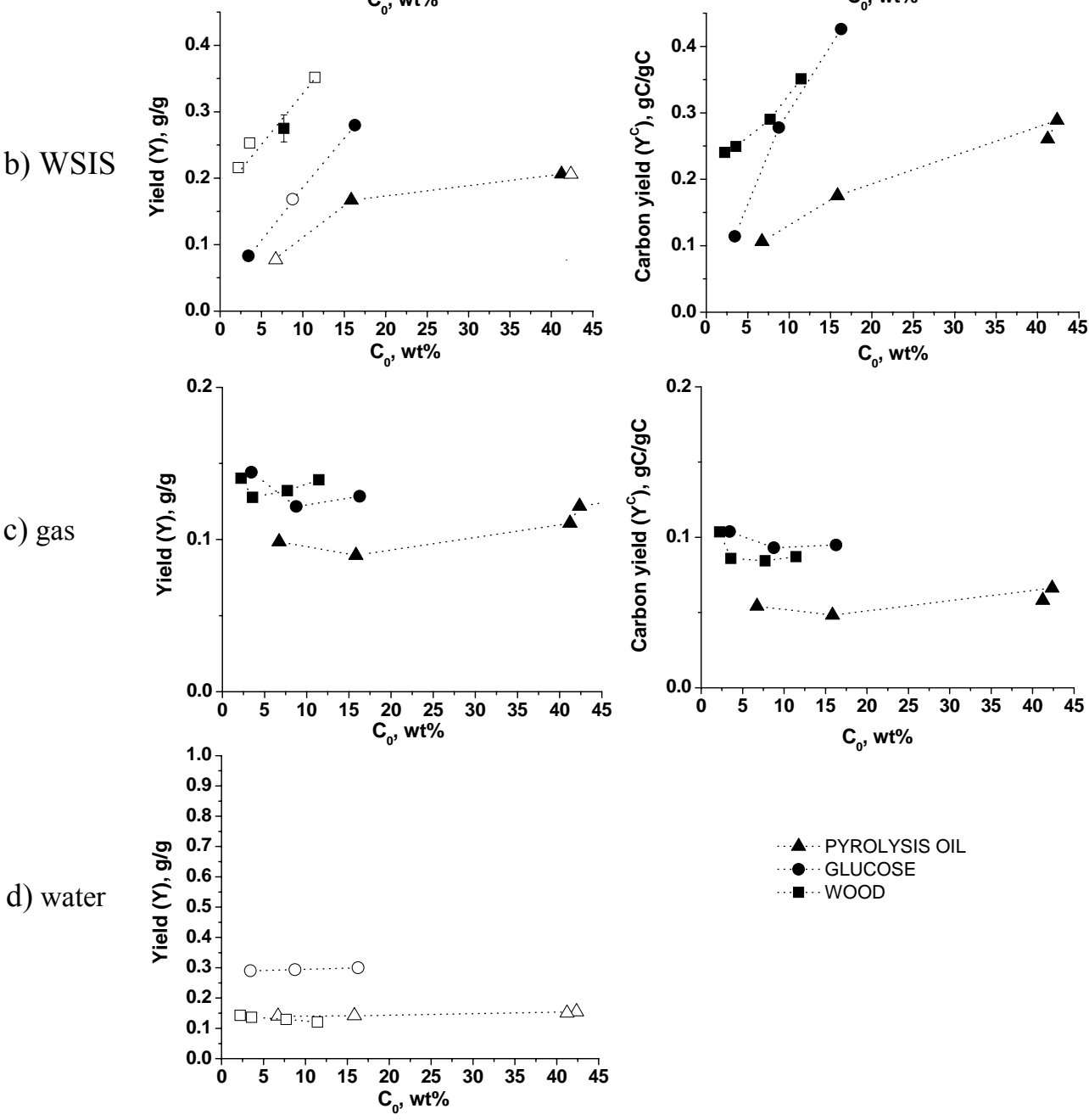

c) gas

Figure 3. Yields and carbon yields of HTC of wood, pyrolysis oil and glucose versus the feedstock concentration. Conditions: HTC: $\tau=10 \mathrm{~min} ; T^{\infty}=350{ }^{\circ} \mathrm{C}, \mathrm{p}=166-180$ bar. Solid symbols are measured HTC data, open symbols are HTC yields calculated from the elemental balances. 


\section{Reaction Path Model}

In Part I a lumped reaction path scheme was proposed for glucose. Here it is extended in order to also describe HTC of solid biomass and pyrolysis oil (see Figure 4). Because all three feedstocks have shown the same yield trends at $\tau>5 \mathrm{~min}$ as a function of residence time and feedstock concentration, the glucose scheme was kept intact and a first dissolution step was added for solid biomass. The steps in and reasoning behind this scheme are summarized below.

i) Dissolution of solid biomass. In this stage probably both chemical and physical phenomena take place. Hydrolysis is most likely an important reaction here that consumes water. The products of the dissolution are primary char and WSS components.

ii) $\quad \mathrm{H}_{2} \mathrm{O}$ is split off from WSS components in the initial stages of HTC process via first order reactions. Glucose and pyrolysis oil are WSS themselves, so the reaction path scheme for them starts here.

iii) A fraction of the WSS components is converted into gases via first order reactions (WSS-A in Figure 4).

iv) Another fraction of the WSS components are converted into WSIS via polycondensation reactions with an order higher than one (WSS-B in Figure $4)$.

v) Reactions of iii) and iv) are not in competition via parallel reactions, i.e. there are different fractions of the WSS product that react to gas and WSIS. If gas and WSIS were formed via parallel reactions from the same WSS fraction, increasing the organics concentration would lead to more char and less gas. Less gas is not observed experimentally.

vi) The work on glucose $e^{4}$ has shown that a certain WSS fraction is stable (WSS-C in Figure 4) and that at longer time scales (hours) WSIS can split off gas $\left(\mathrm{CO}_{2}\right)$. 


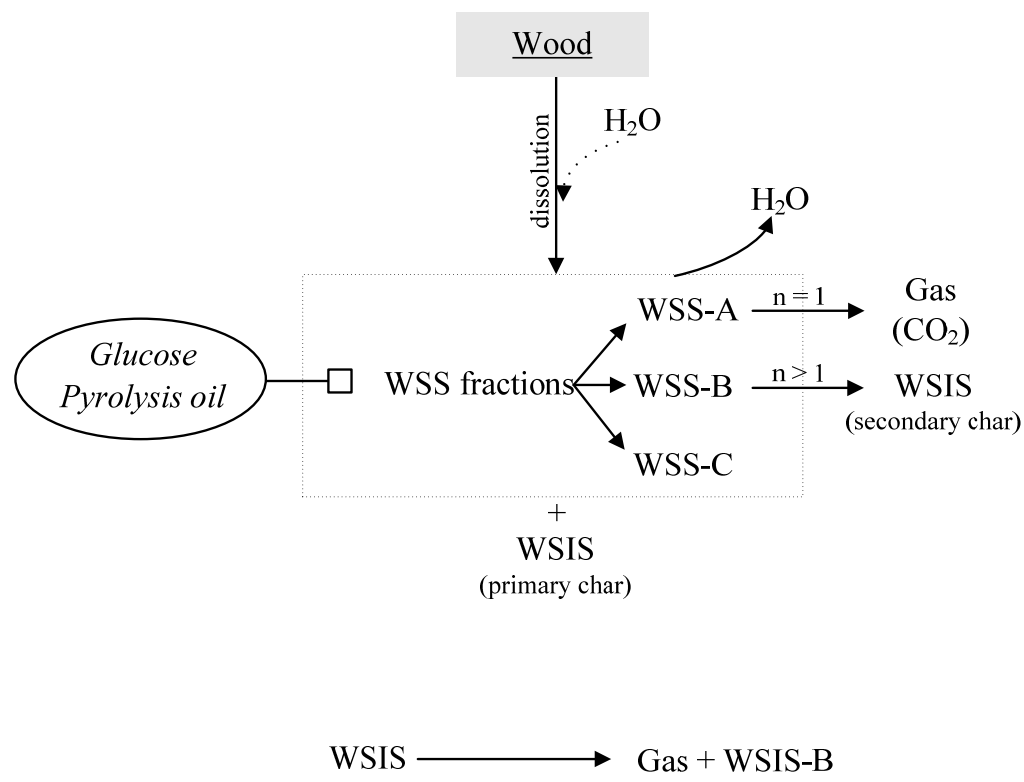

Figure 4. Lumped reaction path model for HTC of biomass.

\section{WSS Composition}

For glucose it has been found that the $\mathrm{H} / \mathrm{C}$ and $\mathrm{O} / \mathrm{C}$ ratios of the WSS reaction product reach stable values, which do not change significantly after ca. $5 \mathrm{~min}$ residence time. ${ }^{4}$ This has also been found for wood and pyrolysis oil. Table 3 gives the typical values of $\mathrm{H} / \mathrm{C}$ and $\mathrm{O} / \mathrm{C}$ ratios of WSS products obtained at 10 min residence time. The WSS product has lower oxygen and hydrogen content compared to the feedstock. As a consequence, the higher heating value of the WSS product is ca. $53 \%, 56 \%$, and $71 \%$ higher than that of wood, pyrolysis oil and glucose, respectively.

Table 3. H/C and O/C of the WSS reaction products of HTC of different feedstocks. ${ }^{a}$

\begin{tabular}{lcccccc} 
& \multicolumn{3}{c}{ Feedstock } & \multicolumn{3}{c}{ WSS product } \\
\cline { 2 - 7 } & $\mathrm{H} / \mathrm{C}$ & $\mathrm{O} / \mathrm{C}$ & $\mathrm{HHV}$ & $\mathrm{H} / \mathrm{C}$ & $\mathrm{O} / \mathrm{C}$ & $\mathrm{HHV}$ \\
\hline Glucose & 2.00 & 1.00 & 15.60 & 1.08 & 0.33 & 26.73 \\
Pyrolysis oil & 1.46 & 0.56 & 16.72 & 1.28 & 0.36 & 26.15 \\
Wood & 1.45 & 0.81 & 16.90 & 1.00 & 0.34 & 25.84
\end{tabular}

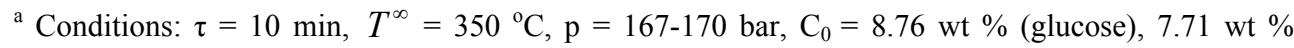
(wood), $6.73 \mathrm{wt} \%$ (pyrolysis oil). 
In Figure 5, molecular weight distributions of various liquids are given. It is clear that the WSS products of pyrolysis oil and glucose HTC are more polymerized than the feedstocks. It can also be noticed that, remarkably, the molecular weight distributions of the WSS product of HTC of wood and glucose and SS product of pyrolysis oil appear rather similar.

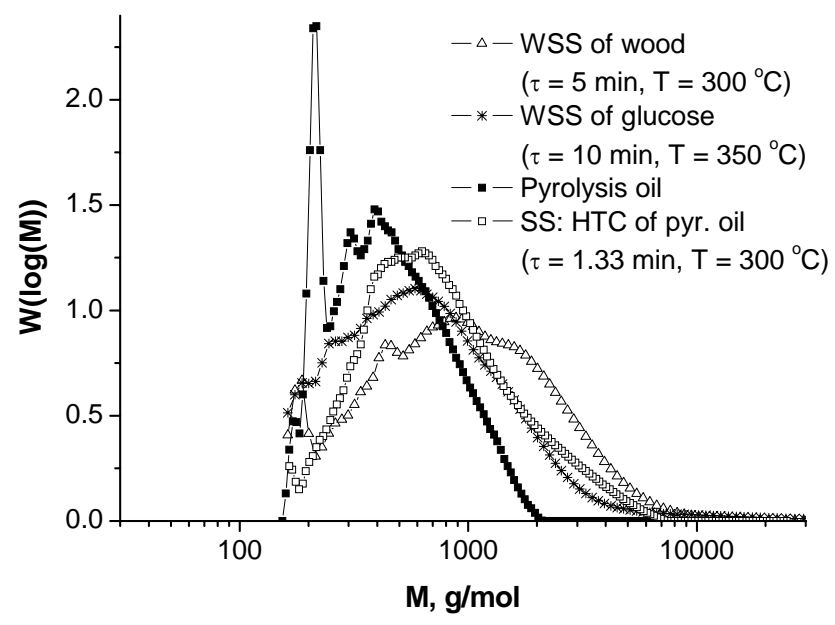

Figure 5. Molecular weight distributions of WSS products of HTC of wood and glucose; SS phase of HTC of pyrolysis oil and pyrolysis oil. Conditions: HTC of wood: $\tau=5 \min , T^{\infty}=300{ }^{\circ} \mathrm{C}, \mathrm{p}=100$ bar; HTC of glucose: $\tau=10 \mathrm{~min}$; $T^{\infty}=350{ }^{\circ} \mathrm{C}$; pyrolysis: $T^{\infty}=500{ }^{\circ} \mathrm{C}$; HTC of pyrolysis oil: $\tau=1.3$ $\min ; T^{\infty}=300{ }^{\circ} \mathrm{C}, \mathrm{p}=100$ bar.

\section{Catalytic Experiments}

Homogeneous and heterogeneous catalysts were screened for enhanced decarboxylation of pyrolysis oil. Results of the gas analysis from experiments at $T^{\infty}=350{ }^{\circ} \mathrm{C}$ and $\tau=10 \mathrm{~min}$ are listed in Table 2.

As with non-catalytic $\mathrm{HTC}, \mathrm{CO}_{2}$ is the main gas product in catalytic experiments, constituting more than $80 \mathrm{vol} \%$ of the gas phase. $\mathrm{CuO}, \mathrm{MoO}_{3}$, and $\mathrm{Ru}$ catalysts significantly improve the $\mathrm{CO}_{2}$ yield. As much as $60 \%$ more $\mathrm{CO}_{2}$ is produced with these catalysts in comparison with the non-catalytic experiment. However, on (absolute) yield basis the maximal increase is not that relevant, namely from $Y_{\mathrm{CO}_{2}}=8.6 \mathrm{wt} \%$ in noncatalytic to ca. $Y_{\mathrm{CO}_{2}}=13.5 \mathrm{wt} \%$ in catalytic experiment. For comparison, when increasing the temperature from 300 to $350{ }^{\circ} \mathrm{C}$ in non-catalytic experiments with pyrolysis oil at 10 
min residence time, the increase of the $\mathrm{CO}_{2}$ production is of the similar magnitude (from $Y_{\mathrm{CO}_{2}}=6.3 \mathrm{wt} \%$ to $Y_{\mathrm{CO}_{2}}=8.6 \mathrm{wt} \%$ ).

When only taking into account the enhanced $\mathrm{CO}_{2}$ production, the tested catalysts probably do not add enough to the process to counterbalance the increased complexity and costs associated with a catalytic process. However, catalysts might influence the yield and composition of the oil and char products in a positive manner.

The use of alkalis in HTC, in particular sodium carbonate and sodium or potassium hydroxide, has been widely reported ${ }^{9-18}$ to be effective towards char reduction. In the early HTC work, sodium carbonate was often used with carbon monoxide, ${ }^{19-21}$ although it has been shown quite early ${ }^{9,18,20}$ that during HTC in alkali solution char is reduced also without carbon monoxide.

Osterman et al. ${ }^{20}$ and Yang et al. ${ }^{22}$ reported no influence of alkalis on the composition of the oils, while $\mathrm{Ogi}^{23}$ reported a slight increase of the $\mathrm{H} / \mathrm{C}$ of the oils obtained with alkalis. In the present investigation visual inspection was used to check if alkalis have an effect on primary char or on secondary char or on both. Figure 6 illustrates that alkalis are effective in terms of both primary and secondary char reduction. It can be noticed that wood shred in alkali solution already at room temperature has yellow color. After $5 \mathrm{~min}$, under hydrothermal conditions, the wood residue (primary char) can not be seen when a $\mathrm{KOH}$ solution is used, while in water the primary char is clearly visible. This observation is in agreement with the work of Fang et al. ${ }^{17}$ who showed complete dissolution of willow during $\mathrm{HTC}$ with $\mathrm{Na}_{2} \mathrm{CO}_{3}$.

When glucose is reacted in water, black solid-like structures are formed. These particles are confirmed to be insoluble in acetone (secondary char). ${ }^{3}$ Figure 6 shows clearly that no secondary char is formed when glucose is reacted in the $\mathrm{KOH}$ solution. Although the char yield (primary and secondary) is reduced by using alkalis, their use in HTC also has drawbacks. Alkalis react in the process and the recovery of sodium or potassium from liquid and solid products could be a complicated and costly procedure. ${ }^{21}$ In contrast, heterogeneous catalysts do not react away and are easy to recover. For this reason we have studied the influence of the $\mathrm{Ru} / \mathrm{TiO}_{2}$ heterogeneous catalyst, which showed the best performance in the pyrolysis oil decarboxylation tests. With this catalyst full mass balances are obtained, and detailed products analyses are performed. The results are summarized in Table 4.

Compared to non-catalytic experiments the tested catalyst i) increases the gas yield, ii) decreases the char yield and have small effect on the oil yield. The lower char yields in catalytic tests suggest that the catalyst is able to convert the WSIS product into gas. This was confirmed in an independent experiment using WSIS product of glucose as a feedstock. In this test of $60 \mathrm{~min}$ at $350{ }^{\circ} \mathrm{C}$ ca. $30 \mathrm{wt} \%$ of gas (on basis of WSIS input) has 
been produced which consist out of $\mathrm{CO}_{2}$ and $\mathrm{CH}_{4}$. Without catalyst, under otherwise identical conditions, gas production was only $2-3 \mathrm{wt} \%{ }^{4}$

Table 4 also shows that the elemental composition of WSS product does not change when catalyst is used.

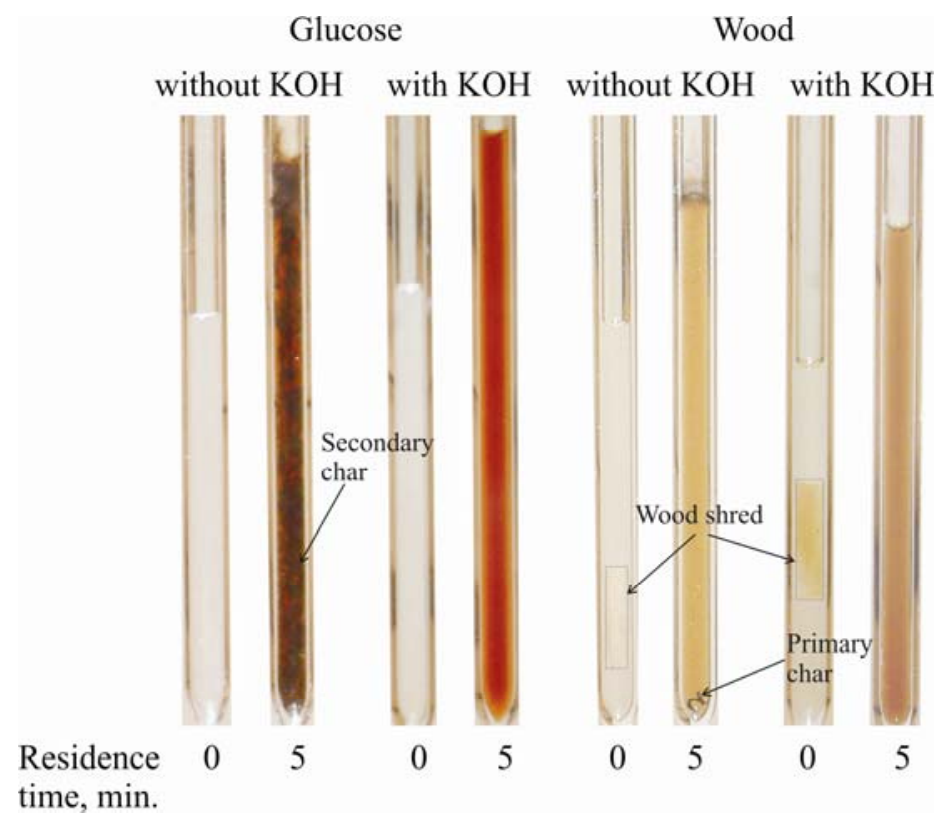

Figure 6. Snapshots of capillaries during reaction with wood and glucose (with and without alkali). Conditions: $\tau=0$ and $5 \mathrm{~min}, T^{\infty}=350^{\circ} \mathrm{C}, \mathrm{C}_{0}=5 \mathrm{wt} \%$ (glucose), $2 \mathrm{wt} \%$ (wood), $\mathrm{p}=166-170$ bar. In catalytic experiments, a $5 \mathrm{wt} \%$ solution of $\mathrm{KOH}$ was used instead of water.

Table 4. Catalytic and non-catalytic HTC of glucose and wood: carbon yields, and WSS product composition $(\mathrm{H} / \mathrm{C}$ and $\mathrm{O} / \mathrm{C}){ }^{a}$

\begin{tabular}{lccccccc} 
& & & \multicolumn{3}{c}{ Carbon yields $\left(Y^{C}\right)$} & \multicolumn{2}{c}{ WSS composition } \\
\cline { 4 - 8 } & $\mathrm{C}_{0}$ & & $\mathrm{WSS}$ & $\mathrm{Gas}$ & $\mathrm{WSIS}$ & $\mathrm{H} / \mathrm{C}$ & $\mathrm{O} / \mathrm{C}$ \\
Feedstock & $\mathrm{wt} \%$ & Catalyst & $\mathrm{gC} / \mathrm{gC}$ & $\mathrm{gC} / \mathrm{gC}$ & $\mathrm{gC} / \mathrm{gC}$ & & \\
\hline glucose & 8 & none & 0.58 & 0.09 & 0.28 & 1.08 & 0.33 \\
glucose & 8 & ${\mathrm{Ru} / \mathrm{TiO}_{2}}_{2}$ & 0.48 & 0.34 & 0.15 & 1.10 & 0.37 \\
wood & 4 & none & 0.61 & 0.09 & 0.25 & 0.95 & 0.42 \\
wood & 4 & ${\mathrm{Ru} / \mathrm{TiO}_{2}}_{2}$ & 0.63 & 0.24 & 0.12 & 1.08 & 0.39
\end{tabular}

${ }^{a}$ Conditions: $\tau=10 \min , T^{\infty}=350{ }^{\circ} \mathrm{C}, \mathrm{C}_{0}$ as given in the table, $\mathrm{p}=166-180$ bar. 
In conclusion, the investigated $\mathrm{Ru}$ catalyst is able to convert WSIS (char) to gas, while leaving the oil product practically unaltered with respect to composition (H/C and O/C) and yield. Hence, the functionality of this catalyst in HTC process is to lower char yield and not to make more WSS product or to improve this products composition. Less char formation is, however, very important in HTC because char is generally considered to cause blockages and is not easy to separate from the oil product.

\section{Phase Behavior of the WSS Product}

At ambient conditions WSS is a two phase product consisting out of an oil and a water phase. It is, however, not known what the mixing state of these phases is under the reaction conditions. To investigate the phase behavior of the WSS product, pyrolysis oil has been reacted under $\mathrm{HTC}$ conditions at $300{ }^{\circ} \mathrm{C}$ and a short residence time of 4 min (low char yield) where after it is cooled to ambient conditions. During cooling, snapshots of the capillary content are taken (see Figure 7). In view of the long total residence time (including cooling) of $40 \mathrm{~min}$, it is necessary to point out that product degradation was limited during the experiment, as the temperature decrease from $300{ }^{\circ} \mathrm{C}$ to $200{ }^{\circ} \mathrm{C}$ occurred in less then $4 \mathrm{~min}$, while $36 \mathrm{~min}$ were required for cooling below $150{ }^{\circ} \mathrm{C}$, where reactions are slow.

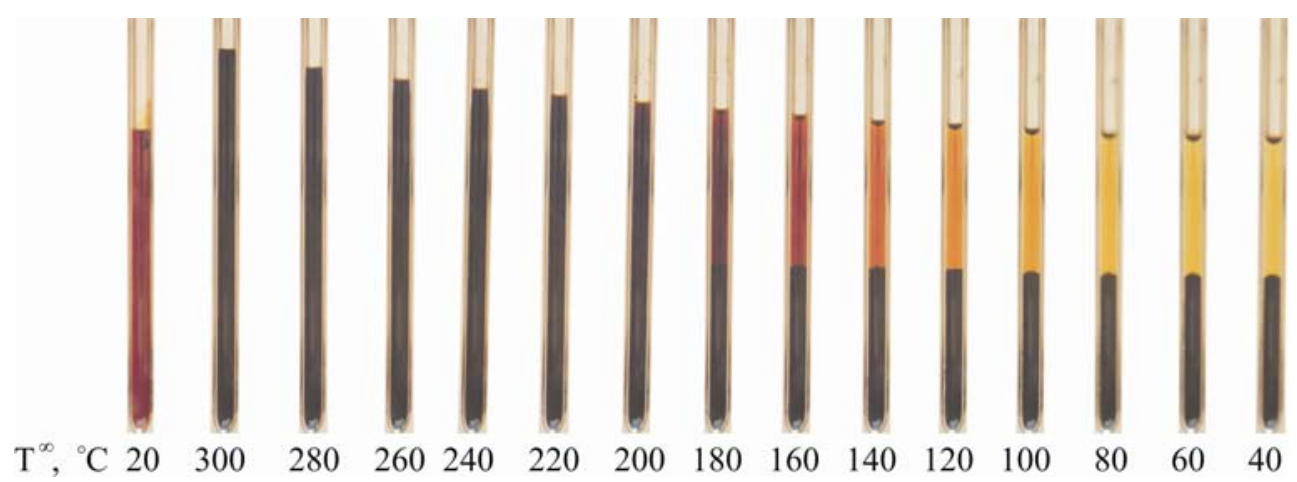

Figure 7. Snapshots of cooling of the products of HTC of pyrolysis oil. Conditions: HTC: $\tau=4$ min, $T^{\infty}=300{ }^{\circ} \mathrm{C}, C_{0}=76.1 \mathrm{wt} \%$ (pure oil), $p \sim 100$ bar; cooling: $\tau_{c}=$ ca. $40 \mathrm{~min}$.

From this visualization it can be concluded that above $220^{\circ} \mathrm{C}$ there exists one liquid phase or a stable emulsion. In the range of $180-220{ }^{\circ} \mathrm{C}$ a phase split occurs. The phase separation in the same temperature range was observed during HTC of wood.

The observation that water phase becomes lighter coloured as the temperature decreases suggests that this phase contains less organics as the temperature decreases. It has been 
observed that upon reheating, with sufficient mixing, one liquid phase is again formed (result not shown).

\section{Discussion and Conclusions}

Hydrothermal conversion (HTC: $200{ }^{\circ} \mathrm{C}<\mathrm{T}<373{ }^{\circ} \mathrm{C}$ ) has been proposed and tested for gas and bio-crude production from biomass. Gasification at such low temperatures requires catalysis, while bio-crude production can be done solely thermally. This discussion deals primarily with bio-crude production via HTC, though co-production of bio-crude and methane is also considered briefly. Bio-crude is a hydrophobic product that typically contains a solvent soluble (oil-like) and solvent insoluble fraction (char-like). The whole bio-crude (oil + char) can be used as feed for combustors (boilers) and gasifiers, while the light (solvent soluble) fraction is proposed as precursor for liquid transportation fuels.

Char formation is a problem of HTC processes: it causes operation problems such as blockages, is difficult to separate from the oil product, and lowers the yield of the more desired product (oil). Our work has clearly identified two types of char: primary char and secondary char. Primary char is the residue that remains after conversion of solid biomass particles. Secondary char is char produced via polymerization reactions of liquid / vaporous decay products. Figure 8 shows a typical yield versus reaction time graph of biomass HTC.

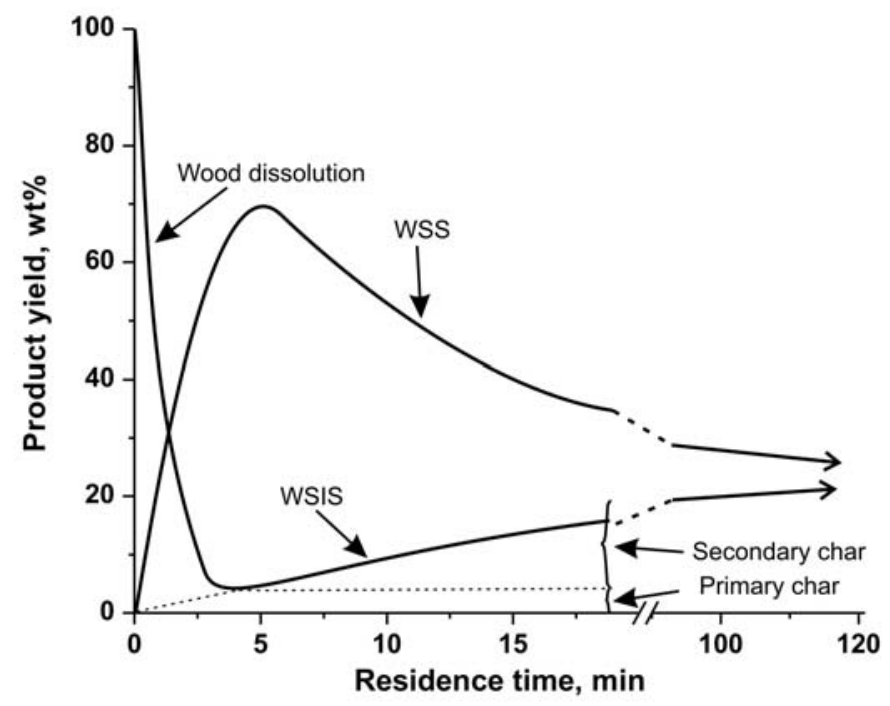

Figure 8. Formation of WSS and WSIS during HTC of wood (trend lines). 
It has been found that very low levels of char (few \% on carbon basis) can be obtained for residence times in the range of 0.5 to $5 \mathrm{~min}$ at $300-350{ }^{\circ} \mathrm{C}$ (see: Boocock et al. ${ }^{24}$, Fang et al. ${ }^{17}$ and our results). In this time period, biomass is rapidly dissolves almost completely and secondary char has not been formed significantly yet. Under these conditions, oil (WSS) yields can be as high as $80 \%$. Such high yields are highly desirable when the transportation fuels precursors are aimed at.

In all reported pilot HTC work $^{19,21,25,26}$ residence time at elevated temperature was, however, much longer, resulting in considerable secondary char formation. The reported light crude (SS - oil) yield is in the range of 20 to $40 \mathrm{wt} \%$. In the pilot plants the aqueous feed stream is heated externally or by heat exchange with the reactor effluent. For both cases it holds that the heating trajectory is already several minutes because of heat transfer limitations. The only way to heat biomass in 1 to $2 \mathrm{~min}$ is injecting the feed directly into a hot liquid which may have a negative influence on the energy efficiency in case of a very wet feedstock, because the sensible heat of the reactor effluent cannot be used for heat exchange with the feed stream.

For combustion (boiler) and gasification application the combined crude (oil + char) yield is important. The values of this combined yield found in this study are in the range of $66-$ $70 \mathrm{wt} \%$ for wood, $68-83 \mathrm{wt} \%$ for pyrolysis oil, and $50-53 \mathrm{wt} \%$ for glucose and do not depend much on the residence time. Our results showed that in case of all three feedstocks, higher feedstock concentrations yield more char at the expense of oil (with very little effect on the water and gas yields). This is a consequence of secondary char formation which has a reaction order higher than 1. Hence keeping the concentration of organics (WSS) low will decrease the char yield. A low concentration of organics can be achieved by using a (very) diluted feedstock, back mixing, or by recycling water over the reactor.

The tested catalyst can reduce the amount of char; however, it does not improve the oil yield or quality with respect to the $\mathrm{H} / \mathrm{C}$ ratio. It does produce more gas, in particular $\mathrm{CH}_{4}$, which could be interesting as co-product. Besides, methane production is exothermic which enables reactor operation with no or less external heat supply.

Oxygen removal in HTC occurs mainly via dehydration and decarboxylation. Via these pathways 60 to $80 \%$ of the oxygen in biomass can be removed leading to liquid products with strongly reduced oxygen content. Decarboxylation is preferred because it removes oxygen with minimal carbon (energy) loss and does not reduce the hydrogen content. Hydrogen is important for the heating value and, in case of the liquid transportation fuel precursor route, high hydrogen content is desired as this lowers the amount of hydrogen addition and/or carbon rejection in the upgrading processes (refining) towards transportation fuels. Our results showed that there is always dehydration next to the desired decarboxylation. In fact for glucose dehydration is dominant: 1.5 to 3 times more oxygen is removed via $\mathrm{H}_{2} \mathrm{O}$ than via $\mathrm{CO}_{2}$. For wood this ratio lies between 1.5 and 0.5 . The oil contains high molecular weight components (up to $10000 \mathrm{~g} / \mathrm{mol}$ ), which means that 
cracking should be a part of the upgrading processes to transportation fuels. Visual observations revealed that a single liquid phase exists under HTC reaction conditions: the oil and the water phase appear to be well mixed. This is important for the reactor design because a single liquid is much easier to deal with than two liquids. In a single liquid there are no de-mixing zones and contact with a possible catalyst is not troubled by additional liquid-liquid mass transfer.

Our work has showed that the product yields of all three feedstocks tested have the same trends with respect to residence time and feedstock concentration. These observations allow the engineering reaction path model developed for glucose $\mathrm{e}^{4}$ to be extended for application with wood and pyrolysis oil feedstock. The extension lays in adding dissolution step for wood and realizing that pyrolysis oil is actually a WSS product. Although it is a lumped component model, it can predict the trends in yields with accuracy sufficient for reactor design. 


\section{Notation}

$\mathrm{C}_{0}$

concentration (wt \% of organics in the feedstock)

D

oxygen removal ratio $\left(\mathrm{R}_{\mathrm{H}_{2} \mathrm{O}} / \mathrm{R}_{\mathrm{CO}_{2}}\right)$

$d_{\text {in }}$

inner diameter of a tube (reactor) (m)

$\mathrm{H} / \mathrm{C}$

molar ratio of hydrogen over carbon $(\mathrm{mol} / \mathrm{mol})$

HHV

Higher Heating Value $(\mathrm{MJ} / \mathrm{kg})$

$L$

length of the capillary (m)

$\mathrm{O} / \mathrm{C}$

molar ratio of oxygen over carbon $(\mathrm{mol} / \mathrm{mol})$

$\mathrm{p}$

pressure (bar)

$\mathrm{R}_{\mathrm{H}_{2} \mathrm{O}}$

percentage of oxygen removed as $\mathrm{H}_{2} \mathrm{O}\left(\mathrm{g} \mathrm{O}\right.$ in $\mathrm{H}_{2} \mathrm{O} / \mathrm{g} \mathrm{O}$ in dry feed* $100 \%)$

$\mathrm{R}_{\mathrm{CO}_{2}} \quad$ percentage of oxygen removed as $\mathrm{CO}_{2}\left(\mathrm{~g} \mathrm{O}\right.$ in $\mathrm{CO}_{2} / \mathrm{g} \mathrm{O}$ in dry feed $* 100 \%)$

$T$

temperature $\left({ }^{\circ} \mathrm{C}\right)$

$T^{\infty}$

preset temperature of the oven $\left({ }^{\circ} \mathrm{C}\right)$

$\mathrm{W}(\log (\mathrm{M}))$

molecular weight distribution

$\mathrm{Y}$

yield of the reaction product ( $\mathrm{g} / \mathrm{g}$ dry feedstock)

$\mathrm{Y}_{\mathrm{CO}_{2}}$

yield of $\mathrm{CO}_{2}$ (g/g dry feedstock)

$Y_{\mathrm{CO}}$

yield of $\mathrm{CO}$ (g/g dry feedstock)

$Y_{\mathrm{CH}_{4}}$

yield of $\mathrm{CH}_{4}$ (g/g dry feedstock)

$Y_{H_{2}}$

yield of $\mathrm{H}_{2}$ (g/g dry feedstock)

$Y^{C}$

carbon yield (g C/ g C in feedstock)

$Y_{\text {gas }}^{C}$

carbon yield of gas ( $\mathrm{g} \mathrm{C} / \mathrm{g} \mathrm{C}$ in feedstock)

$Y_{W S S}^{C}$

carbon yield of the water-solvent soluble reaction product ( $\mathrm{g} \mathrm{C} / \mathrm{g} \mathrm{C}$ in feedstock)

$Y_{W S I S}^{C}$

carbon yield of the water-solvent insoluble reaction product $(\mathrm{g} \mathrm{C} / \mathrm{g} \mathrm{C}$ in feedstock) 


\section{Greek letters}

$\sigma$

$\tau$

$\tau_{c}$ standard deviation

total residence time ( $\mathrm{min}$ )

cooling time (min) 


\section{References}

${ }^{1}$ Potic, B.; Kersten, S. R. A.; Prins, W.; Van Swaaij, W. P. M. A high-throughput screening technique for conversion in hot compressed water. Ind. Eng. Chem. Res. 2004, 43, 4580.

${ }^{2}$ Knežević, D; Schmiedl, D.; Meier, D.; Kersten, S.; Van Swaaij, W. High-Throughput Screening Technique for Conversion in Hot Compressed Water: Quantification and Characterization of Liquid and Solid Products. Ind. Eng. Chem. Res. 2007, 46, 1810.

${ }^{3}$ Knežević, D.; Rep, M.; Kersten, S. R. A.; Prins, W.; Van Swaaij, W. P. M. Hydrothermal liquefaction and pyrolysis: A visualization study. In Science in Thermal and Chemical Biomass Conversion, Victoria, Canada; Bridgwater, A. V., Ed.; Boocock, D. G. B., Ed.; CPL Press, 2006, pp.1082.

${ }^{4}$ Knežević, D.; Van Swaaij, W. P. M.; Kersten, S. R. A. Hydrothermal conversion of biomass: Part I, glucose conversion in hot compressed water. Ind. Eng. Chem. Res. 2009, 48, 4731

${ }^{5}$ Perry, R.H.; Green, D. (eds.), Perry's Chemical Engineers' Handbook, Seventh Edition, McGrawHill Book Company, New York, ISBN 0-07-049841-5, 1999, pp.2-7 - 2-27.

${ }^{6}$ McMillan, J. D. Processes for Pretreating Lignocellulosic Biomass: A Review. Report: NREL/TP421-4978, November 1992.

${ }^{7}$ Mosier, N; Wyman, C; Dale, B; Elander, R; Lee, Y.Y.; Holtzapple, M; Ladisch, M. Features of promising technologies for pretreatment of lignocellulosic biomass. Bioresource Technology 2005, 96, 673 .

${ }^{8}$ Wang, Xiaoquan (2006) Biomass fast pyrolysis in fluidized bed : product cleaning by in-situ filtration. PhD Thesis University of Twente, 2006.

${ }^{9}$ Molton M.P., T.F. Demnitt, J. M. Donovan, R.K. Miller "Mechanism of conversion of cellulosic wastes to liquid fuels in alkaline solution", Conference proceedings: Energy From biomass and wastes, 1978, p.293

${ }^{10}$ Elliott, D. C.; Giacoletto, G.M. Bench scale research in biomass liquefaction in support of the Albany, Oregon, experimental facilitiey Proc. 3rd Annual Biomass Energy Systems Conf., 5-7 June, Golden, Colorado, SERI/TP-33-285, 1979, pp. 123.

${ }^{11}$ Eager, R.L.; Mathews, J. F.; Pepper, J.M. Liquefaction of Aspen Poplar Wood Can. J. Chem. Eng., 1982, 60, 289.

${ }^{12}$ Yokoyama S-Y.; Suzuki, A.; Murakami, M.; Ogi, T.; Koguchi, K.; Nakamura, E. Liquid fuel production from sewage sludge by catalytic conversion using sodium carbonate. Fuel, 1987, 66, 1150.

${ }^{13}$ Krochta, J.M.; Hudson, J.S.; Drake, C.W.; Mon, T.R.; Pavlath, A.E. Thermal Degradation Of Cellulose in Alkali. In: Fundamentals of Thermochemical Biomass Conversion: An International Conference, Estes Park Colorado, 1985, pp. 1073.

${ }^{14}$ Yokoyama S-Y.; Ogi, T.; Kogushi, K.; Minowa, T.; Murakami, M.; Suzuki, A. Liquid fuel production from ethanol fermentation stillage by thermochemical conversion. In: Research in Thermochemical Biomass Conversion (edited by Bridgwater A.V. and Kuester J.L.), Elsevier Applied Science, 1988, pp.792. 
${ }^{15}$ Suzuki, A.; Nakumura, T.; Yokoyama, S-Y.; Koguchi, K. An advanced treatment of sewage sludge by direct thermochemical liquefaction. In: Research in Thermochemical Biomass Conversion (edited by Bridgwater A.V. and Kuester J.L.), Elsevier Applied Science, 1988, pp.816.

${ }^{16}$ Minowa, T.; Zhen, F.; Ogi, T. Cellulose Decomposition in Hot-Compressed Water with Alkali or Nickel Catalyst. J. of Supercritical Fluids, 1998, 13, 253.

${ }^{17}$ Fang, Z.; Minowa, T.; Smith, Jr., R. L.; Ogi, T.; Kozinski, J. A. Liquefaction and Gasification of Cellulose with $\mathrm{Na}_{2} \mathrm{CO}_{3}$ and $\mathrm{Ni}$ in Subcritical Water at $350{ }^{\circ} \mathrm{C}$. Ind. Eng. Chem. Res. 2004, 43, 2454.

${ }^{18}$ Yokoyama, S-Y; Ogi, T; Koguchi, K; Nakamura, E. Direct liquefaction of wood by catalyst and water. Petroleum Science and Technology 1984, 2,155.

${ }^{19}$ Appell, H.R.; Fu, Y.C.; Friedman, S., Yavorsky, P.M.; Wender I. Converting organic wastes to oil: A replenishable Energy Source. Bureau of Mines Report of Investigations, 7560, 1971.

${ }^{20}$ Osterman, R.D.; Bishop, K.A.; Rosson, R.F. Kinetics of The Thermochemical Conversion OF Cellulose To Oil In Aqueous Alkaline Solution. Conference proceedings: Energy From biomass and wastes $I V, 1980$, pp.645.

${ }^{21}$ Wilhelm, D. J; Kam, A.Y.; Stallings, J. W. Transportation fuel from biomass by direct liquefaction and hydrotreating. In: Energy from biomass and wastes V, January 26-30, 1981, Lake Buena Vista, Florida, USA. pp.651.

${ }^{22}$ Yang, Y. F.; Feng, C. P.; Inamori, Y.; Maekawa, T. Analysis of energy conversion characteristics in liquefaction of algae. Resources, Conservation and Recycling, 2004, 43, 21.

${ }^{23}$ Ogi, T., Yokoyama, S-Y.; Kuguchi, K. Direct liquefaction of wood by catalyst part I. Effect of pressure, temperature, holding time and wood/catalyst/water ratio on oil yield. Sekiyu Gakkaishi 1985, 28, 239.

${ }^{24}$ Boocock, D.G.B.; Chowdhury, A.; Kosiak, L. Aspects of the steam liquefaction of poplar wood chips in a gravity fed reactor. In: Research in Thermochemical Biomass Conversion (edited by Bridgwater A.V. and Kuester J.L.), Elsevier Applied Science, 1988, pp.843.

${ }^{25}$ P. M. Molton, A. G. Fassbender, and M. D. Brown STORS: The Sludge-to-Oil Reactor System Report. Environmental protection agency (EPA) EPA/600/S2-86/034, June 1986.

${ }^{26}$ Figueroa, C.; Schaleger, L.L.; Davis, H.G. LBL continuous bench-scale liquefaction unit, operation and results. In: 6. annual conference on energy from biomass wastes, Lake Buena Vista, FL, USA, 25 Jan 1982, pp. 541. 


\title{
CHAPTER 5
}

\section{Development of a Continuous Bench Scale Plant}

\begin{abstract}
A bench scale unit for continuous hydrothermal conversion of biomass has been conceived in conjunction with a "wish list". The unit should be flexible, cheap and safe and should be able to process a variety of feedstocks in different modifications. Critical parts like feeding system and mixing devices, meant to vary the state of macro mixing between plug flow and ideal mixing, have been tested at ambient conditions. As a fluid bed of catalyst is also envisaged in certain applications, operation with a fluid bed has been tested and characterized by residence time distribution measurements and particle mixing tests.

In actual HTC tests it is found that for non-or weakly-coking feedstocks the bench scale unit could be operated. For strongly coking feedstocks and operations with fluid beds additional tests are still required to demonstrate the operability.
\end{abstract}




\section{Introduction}

The reported literature data of the process development and reactor studies of HTC are not easy to unify. To a certain extent, these interpretation difficulties can be ascribed to the experimental facilities used. Typically, autoclaves and large pilot plants (PERC ${ }^{1}, \mathrm{HTU}^{2}$ ) have been used. One of the crucial problems in autoclave reactors is the relatively low heat transfer rate and thermal inertia $\left(m * c_{p}\right)$. Batch autoclaves are essentially non-isothermal. Their heating / cooling times can be very long and during this process some reactions occur (see, e.g., Fang et al. ${ }^{3}$ and Watanabe et al. ${ }^{4}$ ). Therefore these conventional reactor systems are not very suitable for studies of HTC kinetics. In this thesis we therefore developed the quartz capillary technique for cheap, safe and high throughput batch experimentation, while eliminating long heating and cooling periods. In process development, however, next to batch tests, tests in continuous setups need to be performed to demonstrate future continuous operation, as this can not always be accurately predicted from batch results only. Moreover, larger quantities of products are often desired for analysis and performance testing in end application. Large pilot plants have been used but have as disadvantages that operation, modifications, cleaning and reparations are very costly and time consuming. Besides, the experimental cycle (time from beginning of one experiment to the beginning of the next one) is very long (sometimes days/weeks). Moreover, costs of already very expensive high pressure equipment are further increased due to the necessity to use special steels for HTC reactors in order to avoid corrosion.

For these reasons, for research purposes, we propose downsizing a continuous plant for HTC to a flexible, cheap and safe bench scale setup. The setup should allow relatively short experimental cycles (several experiments per day). It should be suitable for the study and demonstration of various issues, such as, chemical kinetics, feeding biomass slurries and/or fouling liquids (pyrolysis oil), heat transfer, phase equilibria, different reactor types, and catalysis. Due to small dimensions, heat transfer should be much faster. The state of macro mixing (continuous ideal mixing vs. plug flow) might be important in the HTC reactors, but has not yet been studied. This setup should allow such studies. Operation with tubular reactors as empty tubes or with fluidized beds of inert or catalytic particles should be possible. Quartz glass is thought of as an ideal reactor material as it is cheap and suitable for screening of small amounts of catalysts without catalytic wall effects. Additionally, quartz allows observation at the reaction conditions, which is a unique opportunity to qualitatively examine the process. To reach sufficient strength for a high pressure process like HTC, a tubular geometry of small diameter is favorable. However, quartz glass is a fragile material, which is why also metal reactors are considered.

In this chapter, the bench scale continuous setup that we propose for the study of the HTC process has been drafted based on a wish list given in Table 1. 
Table 1. Desired properties of a bench scale continuous pilot plant for HTC

\begin{tabular}{|c|c|c|}
\hline 1 & Vessel volume & $\begin{array}{l}\text { Small enough to allow operation outside a concrete HP } \\
\text { box with simple safety protection }\end{array}$ \\
\hline 2 & Feedstock & $\begin{array}{l}\text { 1) sugar solutions, } \\
\text { 2) pyrolysis oil, } \\
\text { 3) waste liquid feeds, } \\
\text { 4) slurries of solid biomass (e.g. wood) in water }\end{array}$ \\
\hline 3 & Reactor operation temperature range & $\begin{array}{l}\text { 1) } 0-200^{\circ} \mathrm{C} \text { (for feed pretreatment studies) } \\
\text { 2) } 200-350{ }^{\circ} \mathrm{C} \text { (for HTC studies) }\end{array}$ \\
\hline 4 & Pressure range & $1-300$ bar \\
\hline 5 & Average residence time & $1-60 \mathrm{~min}$ \\
\hline 6 & Product capacity for one single run & $\sim 5-50 \mathrm{~cm}^{3}$ \\
\hline 7 & Reactor type & $\begin{array}{l}\text { Tubular vessel of small diameter } \\
\text { 1) empty tube, } \\
\text { 2) packed bed, } \\
\text { 3) fluid bed } \\
\text { 4) stirred vessel } \\
\text { 5) controllable mixing state }\end{array}$ \\
\hline 8 & Reactor material & $\begin{array}{l}\text { quartz (for visualization), } \\
\text { corrosion resistant metal (if visualization is not required) }\end{array}$ \\
\hline & Main pump & Standard or improved HPLC pump \\
\hline & Pre-heater & $\begin{array}{l}\text { Simple, because of small scale preferably directly } \\
\text { attached to the reactor. Type: empty tube or with fluid } \\
\text { bed to counteract fouling. }\end{array}$ \\
\hline & Product collectors & Simple: "all product" collectors for separate analysis \\
\hline 12 & Coolers & As simple as possible \\
\hline & Valves & $\begin{array}{l}\text { Preferably: no pressure relieve valve, avoid three phase } \\
\text { valve }\end{array}$ \\
\hline
\end{tabular}

Although this setup has not yet been realized in a fully integrated form, parts of it were tested and proved to be valuable building blocks which were used successfully in research setups in our TCCB group for the studies of supercritical water gasification and flash pyrolysis oil conversion.

The following parts of the setup have been tested and are described in this chapter: i) the biomass feeding system, ii) heat transfer to a small scale empty tubular reactor, iii) operation without pressure reducing valve, and iv) liquid and solid mixing in an empty tubular and a fluidized bed reactor (cold flow tests). Next to that we will discuss typical problems experienced during hot conversion tests. 


\section{General Description of the Continuous Bench Scale Plant}

The setup (see Figure 1) that we propose consists of three parts: a feeding section, a preheating/reaction section and a product collection section.

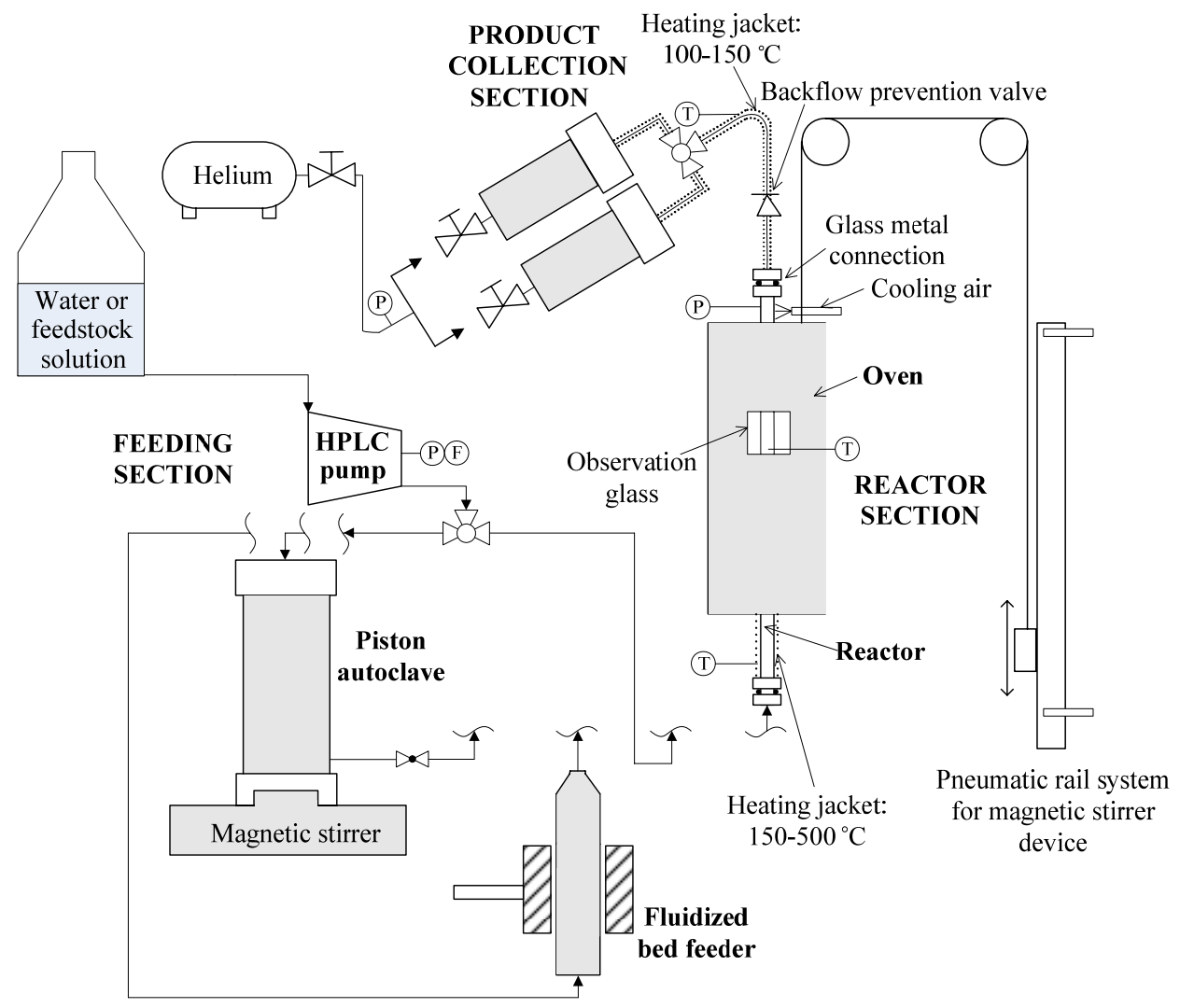

Figure 1. Scheme of the integrated bench scale setup.

Maintaining the whole system under pressure allows minimization of the number of valves. In this way common process bottlenecks: pressure relieve valve and/or back pressure regulator, can be avoided, thus decreasing the possibility of plugging problems.

During operation, the feedstock is transported with the use of a high-pressure pump through the reactor while controlling the temperature. After cooling, the products are collected in one of the two high-pressure vessels (HIP - TOC11: $d_{\text {in }}=0.038 \mathrm{~m}, \mathrm{~L}=0.254 \mathrm{~m}, \mathrm{p}(\max )$ $=482$ bar) containing helium under preset pressure. Depending on the volume of the collection vessel and the amount of the reaction products collected during an experiment, the overall unit pressure will slightly increase (say for $10-20 \%$ of the total pressure). The 
pressure increase needs to be considered when determining the duration of a safe and meaningful (almost isobaric) experiment.

After each test run, the collection vessels are detached from the system and slowly depressurized for gas sampling without the loss of condensed phase products.

Hereunder the sections of the setup are described in more detail, along with the dedicated experiments that were performed to evaluate their individual performance.

\section{Feeding Section}

After pretreatment (size reduction, adjusting the water/biomass ratio and de-aeration), feedstock is fed into the reactor. While feeding of liquids such as sugar solutions is straightforward, direct feeding of biomass-water slurries or fouling fluids (e.g. untreated pyrolysis oil) is very difficult on this small scale. During direct pumping of biomass-water slurries filtering will occur at various places in the pump or feedstock vessels, resulting in biomass accumulation and eventual pump failure. Although complex liquids, such as pyrolysis oil, can be pumped directly with a high pressure pump, flow inaccuracy was experienced in our experiments due to fouling inside the pump, which, together with corrosion, could even cause pump malfunction.

Various feeding systems were considered but not tested, like screw feeders (not practical for this extremely small scale) and peristaltic pumps (to be operated in pressure enclosure). Two systems that were tested for feeding slurries are: a piston autoclave and a lifted fluidized bed. The piston autoclave is also suitable for feeding pyrolysis oil.

\section{Piston Autoclave}

The principle of the piston autoclave feeding system (see Figure 2) is transporting biomass or pyrolysis oil by passing only clean water through the high-pressure pump.

A cylindrical piston autoclave (HIP - TOC27: $d_{i n}=0.076 \mathrm{~m}, \mathrm{~L}=0.254 \mathrm{~m}, \mathrm{p}(\max )=345$ bar) with screw -top and -bottom was used in our tests. The bottom part of the autoclave was charged with biomass-water slurry or pyrolysis oil, while the top part was filled with water. While the whole system was pressurized, water was pumped in the upper chamber by means of the Prep 24 HPLC pump ( $\Phi_{\text {liquid }}=0-4.00 \cdot 10^{-7} \mathrm{~m}^{3} / \mathrm{s} ; \mathrm{p}=0-276$ bar), thus moving the piston and forcing the material out of the autoclave. Successful feeding of pyrolysis oil was realized with this system. For slurry feeding, a magnetic driver placed under the feeding vessel was used to move a magnetic stirrer bar placed inside the vessel. This was meant to ensure that the suspension is mixed and to prevent biomass settling. However, due to the distance between the magnetic driver and the stirrer bar, in dense slurries, the bar moved only irregularly and with difficulty. Therefore, uniform direct 
feeding of slurries as such, was not possible even for the biomass particles of the smallest size used. Difficulties encountered were: settling of biomass, and filtration of particles from the fluid at the outlet of the piston autoclave rendering the outflow inhomogeneous.

In order to stabilize the biomass water suspension and ensure constant water/biomass ratio of the feedstock, the viscosity needed to be increased while still maintaining the stirring action. A stable suspension was formed from: $10 \mathrm{~g}$ carboxymethylcellulose; $15 \mathrm{~g}$ wood $\left(d_{p}\right.$ $\sim 100 \mu \mathrm{m}$ ) and $100 \mathrm{~g}$ water. This modified slurry was pumped successfully. However, an important disadvantage of this concept for feeding biomass slurries is that a high concentration of carboxymethylcellulose was required, which will strongly influence the product distribution.

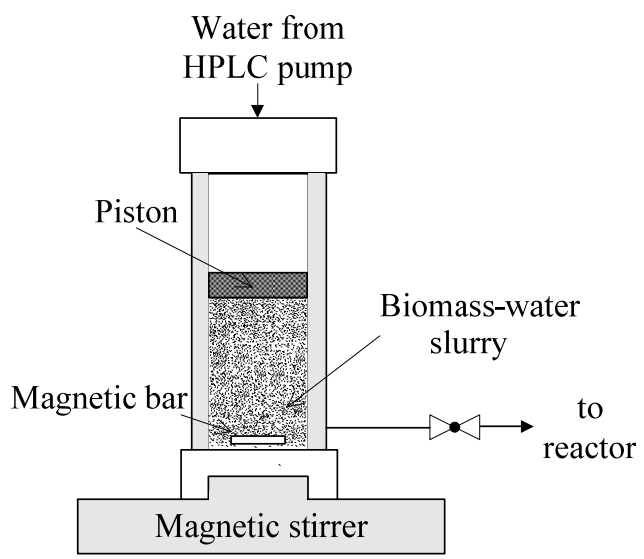

Figure 2. Piston autoclave: cross-section.

\section{Moving Fluidized Bed}

To allow feeding of slurries of pure wood with water, without the need for additives, a special fluidized bed feeding system was designed and tested (see Figure 3).

In a feeding tube which extends to the reactor, the amount of biomass required for a semi continuous run is fluidized at ambient temperature but at the required pressure. While biomass is fluidized, the fluidized bed is continuously moved upwards into the reactor by lifting the magnetic distributor of the fluidized bed. The reactor can be of the same diameter as the feeding tube (provided that the ratio of volumes allows the collection of sufficiently large product sample obtained in quasi-steady state conditions).

The other option is that the reactor diameter is smaller in which case, due to the change in diameter at the feeding device outlet/reactor inlet position, wood particles are transported by hydraulic conveying. The different diameters could also allow introduction of biomass particles into a catalytic stationary fluidized bed of different diameter/density particles in the reactor via a ball distributor (see Potic ${ }^{5}$ ). 


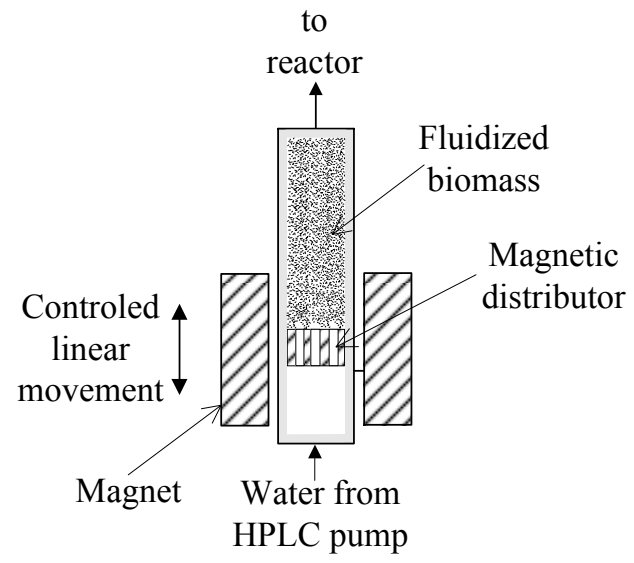

Figure 3. Moving fluidized bed feeder: cross section.

The vertical movement of fluid bed distributor is achieved by another magnet connected to a very precise linear motion control device. This device consisted of a stepper motor with a gearbox and allowed a linear motion speed to be adjusted continuously in the range of 0 $4.2 \mathrm{~mm} / \mathrm{s}$. For dimensioning and operating of such system the conditions of successful fluidization and the desired solid to liquid feeding ratio are to be considered. The following equations apply:

For total liquid flow:

$\Phi_{\text {liquid }}=\Phi_{\text {fluidisation }}+\Phi_{\text {slurry }}\left(\varepsilon+(1-\varepsilon) \varepsilon_{p}\right)$

Total mass flow:

$\dot{m}_{\text {solid }}=\Phi_{\text {slurry }}(1-\varepsilon)\left(1-\varepsilon_{p}\right) \rho_{\text {sk }}$

And for the mass flow ratio:

$$
\frac{\dot{m}_{\text {solid }}}{\dot{m}_{\text {liquid }}}=\frac{\Phi_{\text {slurry }}(1-\varepsilon)\left(1-\varepsilon_{p}\right) \rho_{\text {sk }}}{\left(\Phi_{\text {fluidisation }}+\Phi_{\text {slurry }}\left(\varepsilon+(1-\varepsilon) \varepsilon_{p}\right) \rho_{l}\right.}
$$

To estimate a practical range of mass flow ratios, let us take a reactor with an internal diameter of $2 \mathrm{~mm}$ and a lifted fluid bed storage vessel with a diameter of $4 \mathrm{~mm}$. As biomass particles beach wood particles are taken with a diameter range of $d_{p}=100-150 \mu \mathrm{m}$. In a separate experiment the fluidization expansion graph was measured (see Figure 4). 


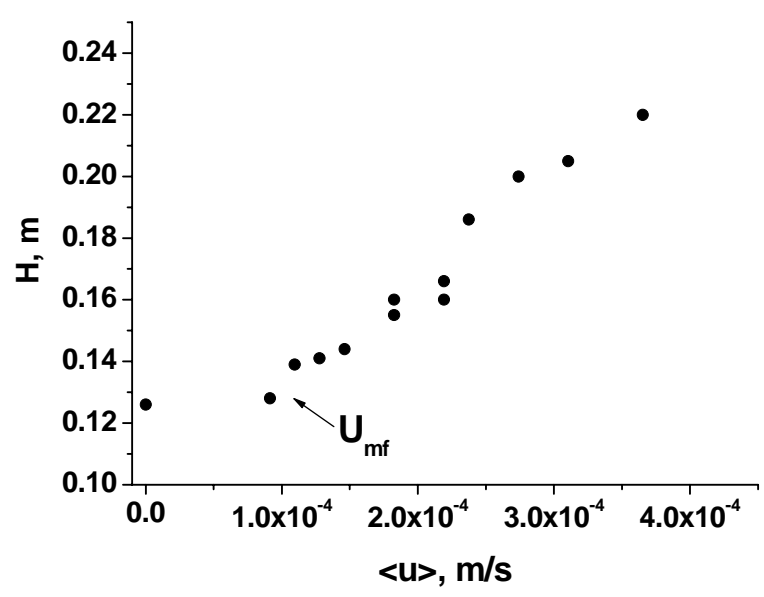

Figure 4. Expansion graph for beech wood particles: $d_{p}=100-150 \mu \mathrm{m}$.

The fluidization was possible, but due to interlocking of particles it was not very smooth at low bed expansions.

The skeletal density $\left(\rho_{s k}\right)$ of the wood particles was estimated to be $1500 \mathrm{~kg} / \mathrm{m}^{3}$. Furthermore it was observed that the unexpanded bed contained $12.7 \mathrm{wt} \%$ of wood.

For the total porosity of the unexpanded bed we obtain:

$\varepsilon_{t}^{0}=1-\frac{\frac{x_{\text {wood }}}{\rho_{s k}}}{\frac{x_{\text {wood }}}{\rho_{\text {sk }}}+\frac{x_{\text {water }}}{\rho_{\text {water }}}}=\varepsilon_{p b}+\left(1-\varepsilon_{p b}\right) \varepsilon_{p}=0.912$

The porosity of the expanded bed can be found from:

$\frac{L}{L^{0}}=1-\frac{1-\varepsilon_{t}^{0}}{1-\varepsilon_{t}}$

Figure 5 shows the wood mass flow ratio as a function of the slurry feed rate at different fluid bed expansions (ambient conditions).

At low slurry pumping rates the mass flow ratio is dominated by the water flow required for fluidization and for higher slurry pumping rates it reaches an asymptote depending on the bed expansion. This asymptote will of course always be below the packed bed limit, which for a zero fluidization flow would correspond to a mass flow ratio of 0.145 . 


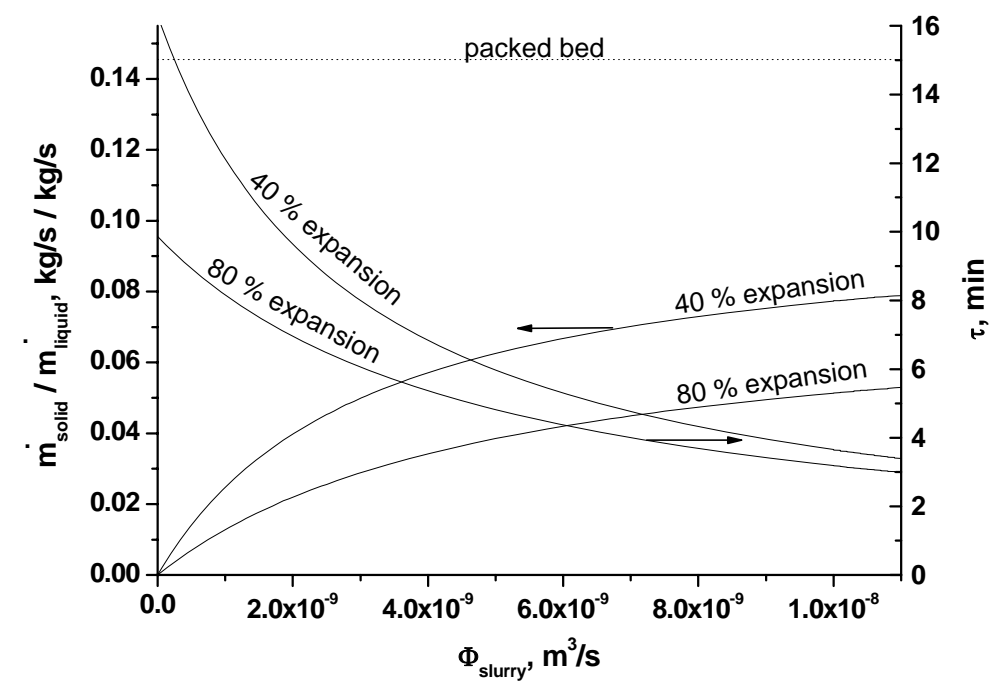

Figure 5. Operating window of lifted fluid bed feeder. $d_{\text {in }}^{\text {reactor }}=0.002 \mathrm{~m}, d_{\text {in }}^{\text {feeder }}=0.004 \mathrm{~m} ; d_{p}=$ $100-150 \mu \mathrm{m} ; L^{\text {reactor }}=0.9 \mathrm{~m} ; \rho_{s k}=1500 \mathrm{~kg} / \mathrm{m}^{3}$.

Figure 5 also shows the resulting reactor residence time (at ambient conditions) if the feeder is discharging into a reactor of $d_{\text {in }}^{\text {reactor }}=2 \mathrm{~mm}$ and $L^{\text {reactor }}=0.9 \mathrm{~m}$, from:

$$
\tau=\frac{V^{\text {reactor }}}{\Phi_{\text {fluidization }}+\Phi_{\text {slurry }}}
$$

Actually at the reactor temperature, the residence times will be shorter due to the lower fluid densities but can be fine-tuned by selecting reactor length and diameter.

The system as sketched in Figure 1, with a reactor tube connected of a diameter equal to half of the feeder diameter, was tested and could be operated with wood particles mostly without blocking. However, an accurate coordination of the linear translation rate of the magnetic distributor and the water feed-pump rate is required. This requires a careful calibration and possibly automation in a final design. 


\section{Preheating}

Preheating of the feedstock is considered to be an integral part of the reactor system.

HTC reactions are only slightly exothermic (see chapter 3 ). Therefore, once feedstock is brought to the desired temperature, the heat duty of the oven is only required to compensate for the heat losses. In case a quartz reactor is used to allow visual inspection during operation, a tube of $d_{\text {in }}=0.004 \mathrm{~m}, d_{\text {out }}=0.006 \mathrm{~m}, L>0.9 \mathrm{~m}$ was considered to be the largest safe reactor. Special attention was needed for the quartz/ metal tube connections, which could only be realized with sufficient stability at lower temperatures of applications (say $\mathrm{T}<100^{\circ} \mathrm{C}$ ). This part should therefore be outside the oven and the heat exchanging part.

If observation during the reaction is intended, heating is performed with the hot air oven. ${ }^{6}$ However, the preheating itself could not be realized by the heat transfer inside the oven. This was measured by special tests in which an external heat transfer coefficient $\alpha_{O D}^{\text {oven }}=25$ $\mathrm{W} / \mathrm{m}^{2} /{ }^{\circ} \mathrm{C}$ was observed. The values of heat transfer coefficient on the water side were estimated by Sieder-Tate correlation ${ }^{7}$ to be $\alpha_{I D}=230-470 \mathrm{~W} / \mathrm{m}^{2} /{ }^{\circ} \mathrm{C}$. The values of conductivity factor $\lambda / \delta$ are $>26500 \mathrm{~W} / \mathrm{m}^{2} /{ }^{\circ} \mathrm{C}$ for the steel tube and ca. $650 \mathrm{~W} / \mathrm{m}^{2} /{ }^{\circ} \mathrm{C}$ for the quartz tube. Clearly, overall heat transfer is externally limited and too low. Therefore electric heating tape $\left(L=0.8 \mathrm{~m} ; \mathrm{P}=350 \mathrm{~W}, \mathrm{~T}(\max )=.450{ }^{\circ} \mathrm{C}\right)$ was placed in the lower part of the steel reactor tube (heating zone).

Quartz reactors were not yet tested with the heating tape because of their fragility.

In order to calculate the external heat transfer coefficient in the tape region around the steel tube, temperature of water flowing inside the reactor was measured at two different locations and under different water flow rates with and without the heating tape. If the heating tape was present, its temperature was controlled independently.

To calculate the $\alpha_{O D}^{\text {heating tape }}$ the measured temperatures were used in heat balance equations:

$$
\begin{aligned}
& \dot{Q}=\dot{V} \rho_{l}(\bar{T}) c_{p, l}(\bar{T})\left(T-T_{0}\right)= \\
& =\frac{1}{\left(\frac{1}{\alpha_{I D}(\bar{T})}+\frac{\delta}{\lambda}+\frac{1}{\alpha_{O D}^{\text {heating tape }}}\right)} \pi \bar{d} L \frac{\left(T_{\infty}^{\text {heating tape }}-T_{0}\right)-\left(T_{\infty}^{\text {heating tape }}-T\right)}{\ln \left(\frac{\left(T_{\infty}^{\text {heating tape }}-T_{0}\right)}{\left(T_{\infty}^{\text {heating tape }}-T\right)}\right)} \quad \text { for } L \leq L^{\text {heating tape }} \\
& =\frac{1}{\left(\frac{1}{\alpha_{I D}(\bar{T})}+\frac{\delta}{\lambda}+\frac{1}{\alpha_{O D}^{\text {oven }}}\right)} \pi \bar{d} L \frac{\left(T_{\infty}^{\text {oven }}-T_{0}\right)-\left(T_{\infty}^{\text {oven }}-T\right)}{\ln \left(\frac{\left(T_{\infty}^{\text {oven }}-T_{0}\right)}{\left(T_{\infty}^{\text {oven }}-T\right)}\right)} \text { for } L>L^{\text {heating tape }}
\end{aligned}
$$


along with predicted values for $\alpha_{I D}$ and measured value for $\alpha_{O D}^{\text {oven }}$.

Figure 6 presents the temperature profiles along the reactor, calculated with obtained heat transfer coefficients, and the measured values indicating a good fit.

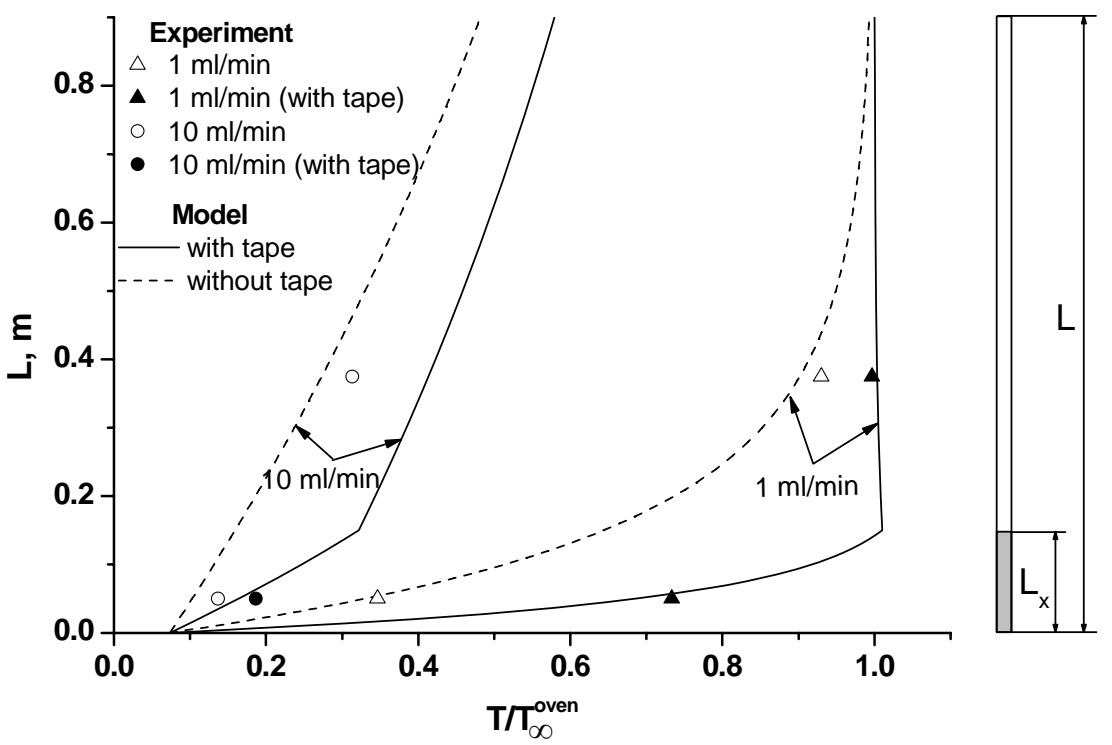

Figure 6. Temperature profiles inside the reactor with and without heating tape. Points: measured values; lines: values calculated using the obtained heat transfer coefficients. Steel reactor: $d_{i n}=0.004$ $\mathrm{m} ; d_{\text {out }}=0.006 \mathrm{~m} ; L=0.9 \mathrm{~m} ; L$ (covered with heating tape $)=0.15 \mathrm{~m}, T_{\infty}^{\text {heating tape }}=330{ }^{\circ} \mathrm{C} ; T_{\infty}^{\text {oven }}=$ $300{ }^{\circ} \mathrm{C}$.

From Figure 6 it follows that the observed temperature profile inside the reactor tube is acceptable for cold water flow rate $\Phi_{\text {liquid }}=1 \mathrm{ml} / \mathrm{min}$, corresponding to the typical HTC reactor residence times of ca. $10 \mathrm{~min}$. If no tape is installed or too high fluid velocities are applied, preheating lengths become too long. This could, to some extent, be improved if the driving force is increased by increasing the heating tape temperature.

This analysis shows the necessity of a high heat flux at the reactor inlet if isothermal operation is desired. Applying a heating tape is clearly one possible means of achieving this. This was further developed by de Miguel Mercader et al. ${ }^{8}$ who also used a reactor of similar dimensions. They used a capillary coil wrapped around a cylindrical heater for heating the pyrolysis oil to the desired temperature. Pyrolysis oil and glucose solutions were heated rapidly, while flowing through the capillary with high velocity, thus preventing char deposition. With pyrolysis oil as the feedstock the system has worked well in most 
cases under HTC conditions due to lower amount of char produced with this feedstock. With glucose operation was possible with diluted solutions (ca. $1 \mathrm{wt} \%$ ) and using short residence times under HTC conditions (typically 1-2 min), which ensured that less char is produced (for char formation kinetics see chapters 3 and 4).

\section{Reactor}

The reactor should be flexible and preferably allow to realize different configurations:

a) empty tube plug flow,

b) empty vessel stirred tank (CISTR),

c) packed bed heterogeneous catalytic reactor,

d) fluid bed catalytic reactor,

e) stirred vessel heterogeneous catalytic reactor.

Because, as described in chapter 3, the reaction path scheme consists of serial and parallel reactions including reactions with reaction order higher than 1 , the reaction system of HTC may be quite sensitive to the state of macro mixing in the reactor, with plug flow and ideal mixing as extremes. It is known (see, e.g., Westerterp et al. ${ }^{9}$ ) that in case of non-linear reactions and complex reaction networks, the conversion and selectivity may be strongly influenced by the state of macro mixing (expressed as the equivalent number of tanks in series or the Peclet number) and to some extent by micro mixing. For instance, for HTC it was found (see chapters 3 and 4 ) that the reaction order of the reaction leading to secondary char is higher than one. This indicates that the state of mixing in the reactor can be expected to influence the amount of char produced and therefore, the study of macro mixing in the reactor is required.

The effect of the change in macro mixing can sometimes be studied by recycling of the reactor effluent to the inlet of the reactor at high recycle ratios to simulate a CISTR operation; but, due to the harsh conditions, complex reactor configurations and complex mixtures, this is not considered possible for HTC on bench scale. Therefore it was attempted to increase the macro mixing in the reactor by an externally driven mixing device (see Figure 7).

To create axial mixing in the fluid in this setup, an external magnet is driving up and down an internal cylindrical magnetic bar, which has a diameter slightly smaller than the reactor inner tube diameter. The vertical movement was achieved by using a pneumatic rail, along which the external magnet was moved with constant frequency $(1.6 \mathrm{~Hz})$. The mixing system was designed for operation inside the reactor oven by selecting special magnetic materials (AlNiCo magnets with Curie point around $800{ }^{\circ} \mathrm{C}$ ), but was tested at ambient conditions. 


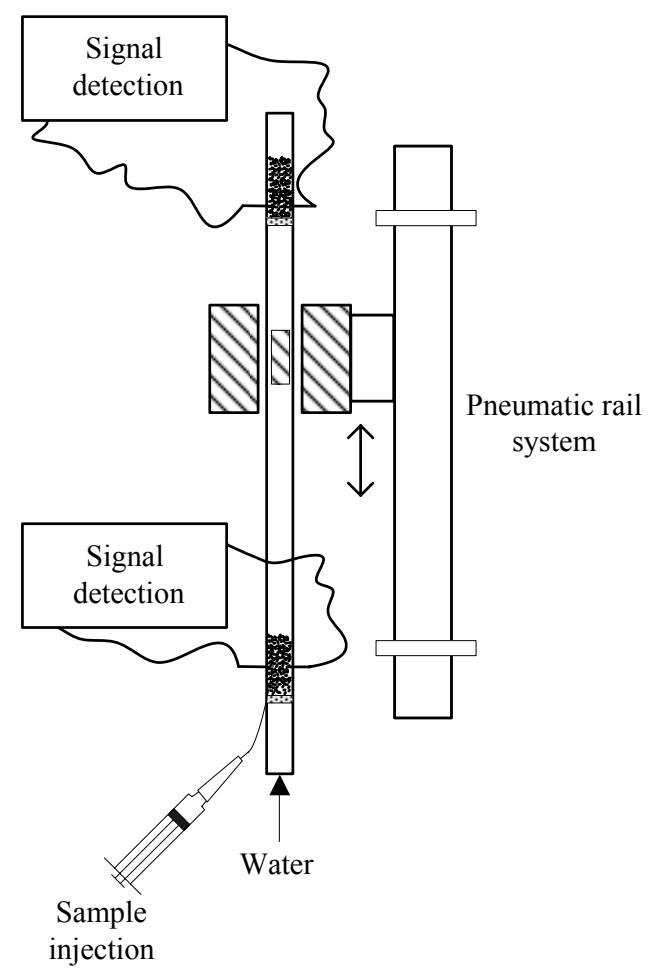

Figure 7. Scheme of the mixing setup.

To test the effect on the macro mixing, residence time distributions were determined for an empty tubular reactor by a pulse injection technique, with and without the mixing device. A vertically positioned glass tube $\left(d_{\text {in }}=0.00412 \mathrm{~m} ; d_{\text {out }}=0.006 \mathrm{~m}\right)$ was used and was fed with water in up flow. Fixed beds of glass particles $\left(d_{p}=0.5-1 \mathrm{~mm}\right)$ were placed around the electrodes to minimize back-mixing (see Figure 7). The length of the experimental zone (empty tube between the fixed beds) was $0.9 \mathrm{~m}$. The sample injection point was close to the bottom electrode pair in a packed bed of glass beads, which minimized the flow distortion due to the injection. A solution of $\mathrm{NaCl}\left(1 \mathrm{~mol} / \mathrm{dm}^{3}\right)$ was used as a marker and was introduced at the bottom of the measuring tube as a Dirac (needle) signal $\left(t_{\text {injection }}<1 \mathrm{~s}\right)$. Two pairs of platinum electrodes were used for signal detection at both ends of the tube (see Figure 7). The $5 \mathrm{kHz}$ current was used and the tracer was detected via conductivity measurements.

From the obtained $\mathrm{C}(\mathrm{t})$ curves, the $E(t), \sigma_{t}^{2}$ and $\bar{t}$ were calculated for the top and the bottom signal using the following equations (see Westerterp et al. ${ }^{9}$ ): 


$$
\begin{aligned}
& E(t)=\frac{C(t)}{\int_{0}^{\infty} C(t) d t} \\
& \bar{t}=\int_{0}^{\infty} t E(t) d t \\
& \sigma_{t}^{2}=\int_{0}^{\infty}(t-\bar{t})^{2} E(t) d t
\end{aligned}
$$

For global inspection, the residence time distribution top signal is considered representative for the system measured (the deviations of the bottom signal from an ideal Dirac pulse are neglected). However, the $\bar{t}$ and $\sigma_{t}^{2}$ for the system were calculated as the difference between these parameters for top and bottom signal.

With assumption of no adsorption on the walls and constant density, normalized residence time and residence time distribution $\theta$ and $E(\theta)$ and $\sigma_{\theta}^{2}$ can be calculated as follows:

$$
\begin{aligned}
& \theta=\frac{t}{\bar{t}} \\
& E(\theta)=E(t) \bar{t} \\
& \sigma_{\theta}^{2}=\int_{0}^{\infty}(\theta-\bar{\theta})^{2} E(\theta) d \theta
\end{aligned}
$$

\section{Results of the Residence Time Distribution in Empty Tubular Reactor}

Results for the empty tube with and without mixing are presented in Figure 8 for two flow rates (corresponding to: $\tau=3.6 \mathrm{~min}$ and $13.1 \mathrm{~min} ;\langle u\rangle=4.11$ and $1.13 \mathrm{~mm} / \mathrm{s}$ ).

Under these conditions, Reynolds number for the reactor is 1.68 and 0.46 , respectively, so clearly in the laminary flow regime. In this regime the residence time distribution is mainly caused by the difference in velocities in the centre of the tube and close to the wall. ( $u_{\max }=2<u>$ ). Without taking the molecular diffusion into account, this would give rise to the residence time distribution or frequency function $\mathrm{E}$ (see, e.g. Westerterp et al. ${ }^{9}$ ), indicated in Figure 8 for laminary flow.

Due to molecular diffusion in radial direction, fast flowing fluid molecules from the centre of the tube are exchanged with the slower flowing elements near the wall, which reduces the spread in residence time. 


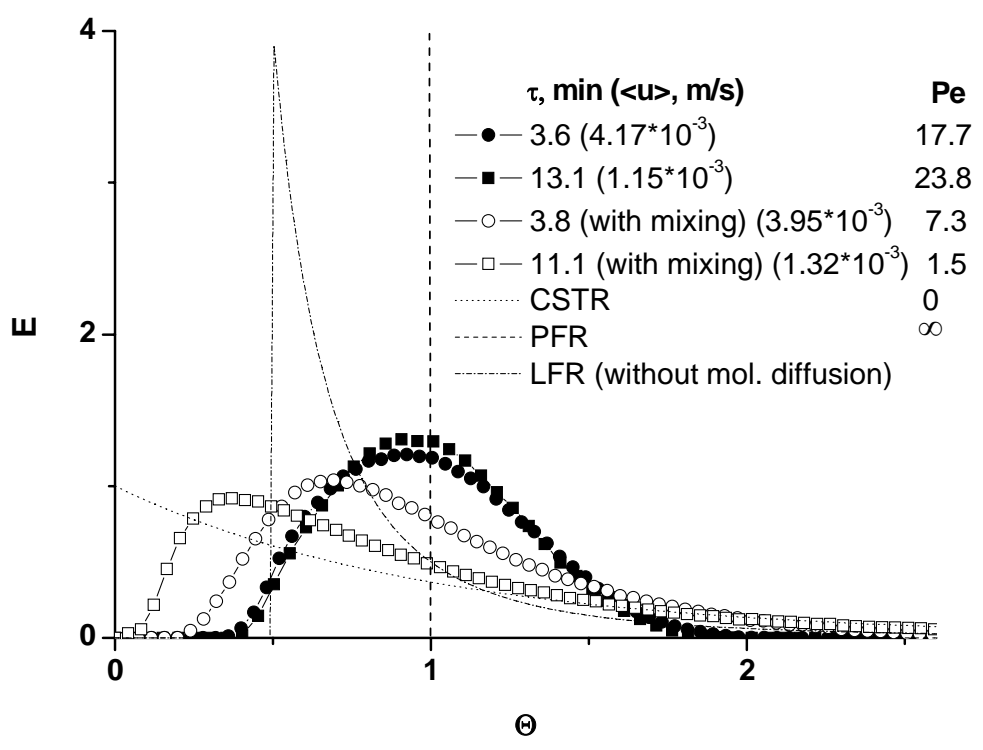

Figure 8. Reduced residence time distribution: $E(\theta)$ in the empty tube. $d_{i n}=0.00412 \mathrm{~m} ; \mathrm{L}=0.9 \mathrm{~m}$.

The effect of molecular diffusion in axial direction can normally be neglected (especially for laminary flow of liquid). The effective axial dispersion for the axial dispersed plug flow model can be calculated from Aris ${ }^{10}$ :

$$
\begin{aligned}
& D_{L}=\mathbf{D}+\frac{d_{\text {in }}{ }^{2}<u>^{2}}{192 \mathbf{D}}, \text { while } \\
& P \mathrm{e}=\frac{<u>L}{D_{L}}
\end{aligned}
$$

where $\mathrm{Pe}$ is the Peclet number for the reactor tube $(\mathrm{Pe}=0 \rightarrow$ ideal mixing, $\mathrm{Pe}=\infty \rightarrow$ plug flow).

The Peclet number thus calculated is plotted for our conditions in Figure 9. 


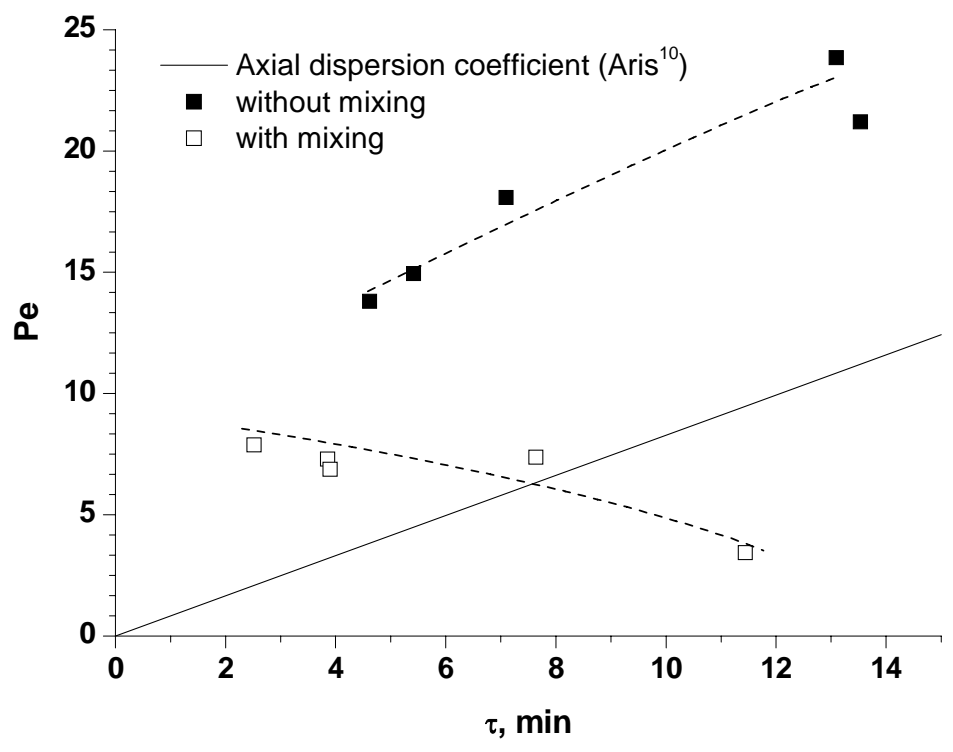

Figure 9. Peclet number as a function of the residence time in the reactor. $d_{i n}=0.00412 \mathrm{~m} ; \mathrm{L}=0.9$ m.

The experimental Pe values have been derived from the equation:

$\sigma_{\theta}^{2}=\frac{2 P e-2+2 e^{-P e}}{P e^{2}}$

using experimentally obtained values of $\sigma_{\theta}^{2}$. The values are higher than those expected for Taylor flow. However, for Taylor flow the fully developed diffusion regime should be established meaning that the Fourier time should be much shorter than the average residence time:

$\tau_{F}=\frac{d_{i n}^{2}}{\mathbf{D}}<<\frac{L}{<u>}$, or Pe $>>200$

which is not the case for our reactor. For shorter residence times effective diffusion rates are higher because of the higher gradients.

Other factors may also have disturbed the hydrodynamics, such as the distributors and the remains of the pulsation of the pump. 
The observed Pe numbers are still high enough for the empty tubular reactor to be considered as in plug flow and even the Taylor flow predictions of Pe for $\tau>10 \mathrm{~min}$ are high enough to conclude plug flow.

In Figure 8 also the residence time distributions of the empty tube reactor are given under the conditions that the magnetic mixer is active.

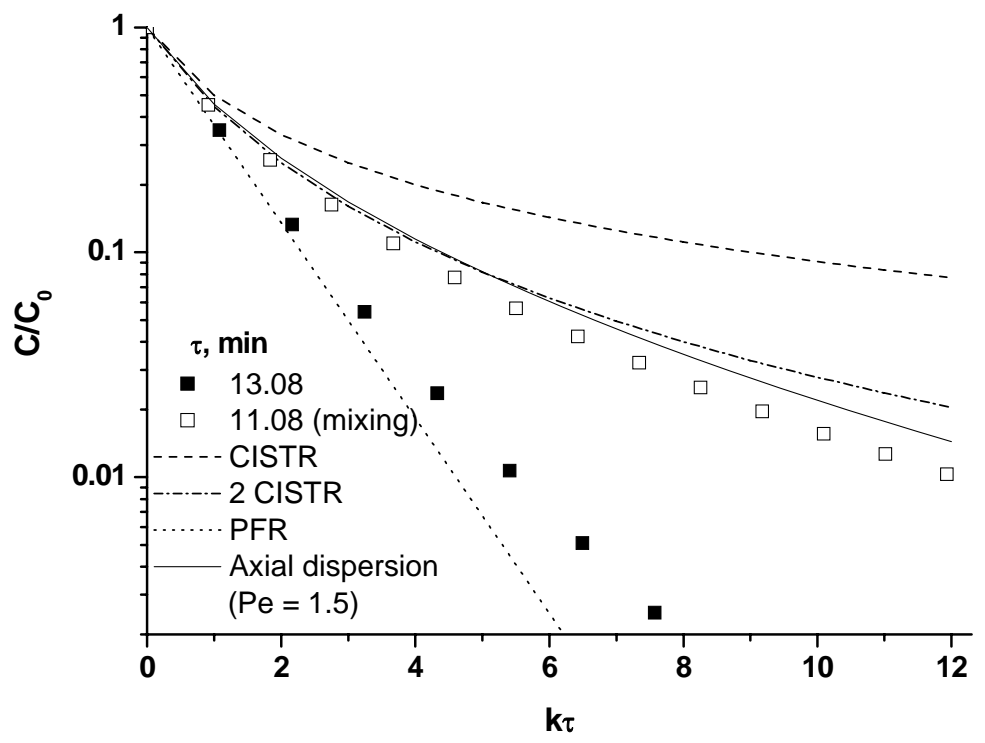

Figure 10. First order reaction in an empty tube (long residence times) and ideal reactors.

Especially for long residence time, the relative axial mixing is strongly increased giving Pe $=1.5$. To demonstrate the effect of macro mixing on chemical reactions, Figure 10 presents the conversion characteristics of a reactor with different mixing states as a function of the dimensionless reaction rate for a first order reaction.

Based on the observed residence time distribution curves, this conversion can be calculated from:

$$
\frac{C}{C_{0}}=\int_{0}^{\infty} e^{-k t} \cdot E(t) d t
$$

Replacing the appropriate $\mathrm{E}(\mathrm{t})$, the concentration profile is given with: 
$\frac{C}{C_{0}}=e^{-k t}$, for plug flow reactor

$\frac{C}{C_{0}}=\frac{1}{1+k \tau}$, for CISTR:

$\frac{C}{C_{0}}=\left(\frac{1}{1+\frac{k \tau}{2}}\right)^{2}$, for 2 CISTR's:

Experimental values are given for the longest residence times, where the effect of mechanical mixing was the most pronounced.

It is clear that with the mixer off almost plug flow conditions are reached, but with the mixer on, the characteristics are still close to $\mathrm{Pe} \sim 1.5$, or close to 2 mixers in series, rather than a single one.

It is somewhat disappointing, however, that the ideal mixer performance (CISTR) in an empty tubular reactor cannot be reached by our type of mechanical mixing (see Figure 8). Direct comparison within a single test run by simply operating with and without mixer is not possible with these dimensions. For CISTR operation the reactor should be much shorter and fluid flow rate smaller, or a special reactor will have to be designed and constructed.

\section{Fluidized Bed Reactor Operation}

Fluid bed operation could serve two purposes for a bench scale reactor setup. The fluidized particles could act as a deposition area for char or gums avoiding excessive rates of reactor plugging on this small scale; and the particles could also act as heterogeneous catalyst.

Compared to a packed bed, fluid bed is less sensitive for plugging and could possibly handle micro slurries of biomass. However, these characteristics will depend on the fluidization properties. For an extremely small diameter fluid bed with high aspect ratio, little data are available in the open literature and therefore several properties were measured in this investigation. 


\section{Bed Expansion}

Fluidization properties of glass particles $\left(d_{p}=100-150 \mu \mathrm{m}\right)$ were measured in a fluid bed created in a quartz tube $d_{i n}=0.0041 \mathrm{~m}, L_{0}=0.147 \mathrm{~m}$ at ambient temperature with water as a fluidizing agent. A typical expansion graph is given in Figure 11.

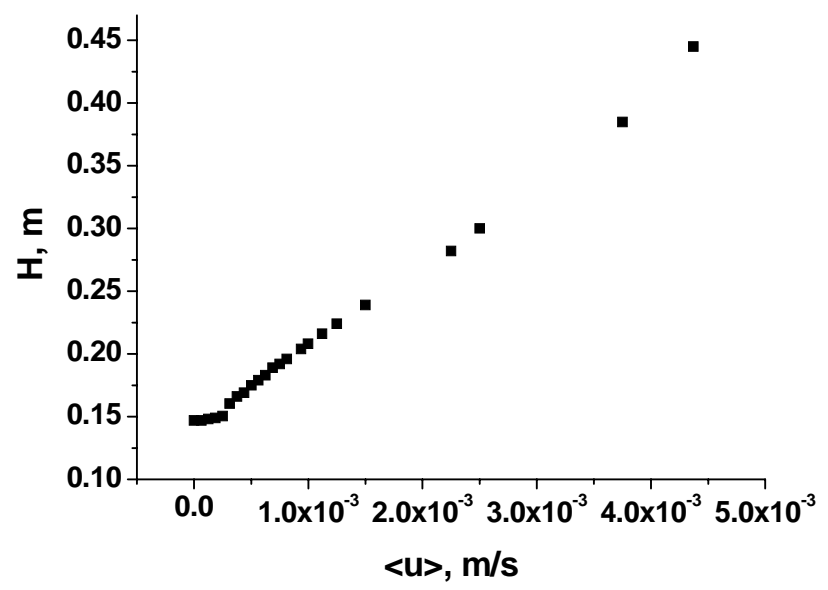

Figure 11. Expansion graph for fluidized bed of glass particles. $d_{p}=100-150 \mu \mathrm{m}, \rho_{s}=2439.5$ $\mathrm{kg} / \mathrm{m}^{3}$.

Minimum fluidization velocity $\left(\mathrm{U}_{\mathrm{mf}}\right)$ is calculated from the balance of forces using the Ergun equation (eq. 22), $U_{t}$ is calculated from Stokes' law (eq. 23) and $n$ from correlation of Khan and Richardson (1989) ${ }^{11}$ (eq. 24).

$-\frac{\Delta p}{L}=150\left(\frac{(1-\varepsilon)^{2}}{\varepsilon^{3}}\right)\left(\frac{\mu_{l}<u>}{d_{p}}\right)+1.75\left(\frac{(1-\varepsilon)}{\varepsilon^{3}}\right)\left(\frac{\rho_{l}<u>^{2}}{d_{p}}\right)=g\left(\rho_{s}-\rho_{l}\right)(1-\varepsilon)$

$U_{t}=\frac{g d_{p}^{2}\left(\rho_{s}-\rho_{l}\right)}{18 \mu}$

$\frac{4.8-n}{n-2.4}=0.043 A r^{0.57}$

where $\mathrm{Ar}$ is the Archimedes number for the particle (eq. 25). 


$$
A r=\frac{g d_{p}^{3} \rho_{l}\left(\rho_{s}-\rho_{l}\right)}{\mu_{l}^{2}}
$$

The fluidization properties are given in Table 2.

Table 2. Fluidization parameters of glass particles: $d_{p}=100-150 \mu \mathrm{m}$.

\begin{tabular}{lcccc} 
& Experiment & & \multicolumn{2}{c}{ Theory } \\
\cline { 5 - 5 } \cline { 4 - 5 } & $100-150$ & & 100 & 150 \\
$d_{p}, \mathrm{~mm}$ & $2.50 * 10^{-4}$ & & $1.00 * 10^{-4}$ & $2.20 * 10^{-4}$ \\
$U_{m f}, \mathrm{~s}$ & & & & \\
$U_{t} / \mathrm{s}$ & $1.18 * 10^{-2}$ & & $8.80 * 10^{-3}$ & $1.99 * 10^{-2}$ \\
$\mathrm{n}$ & 4.28 & & 4.36 & 4.06
\end{tabular}

Despite the extreme dimensions, the glass beads fluid bed still behaves according to the empirical relations set up for other conditions.

\section{Residence Time Distribution of Liquid in the Fluid Bed Reactor}

Similar to the empty tube tests, the residence time distributions of the liquid phase were measured for the liquid fluidized beds. The experiments without mixing were done with two flow rates (corresponding to: $\tau=3.6$ and $7.2 \mathrm{~min} ;\langle u\rangle=0.0041$ and $0.0021 \mathrm{~m} / \mathrm{s}$ ). The influence of the magnetic mixer set-up was tested under similar flow rates (corresponding to: $\tau=3.4$ and $6.6 \mathrm{~min} ;\langle u>=0.0044$ and $0.0023 \mathrm{~m} / \mathrm{s}$ ). The results are given in Figure 12 .

For fluidized bed residence time distribution experiments, particles of $100-150 \mu \mathrm{m}$ were fluidized. With decreasing flow rate, glass particles were added to maintain the equal bed height regardless of the flow rate. The ratio of particle to bed diameter is in the range of $26-40$ and normal liquid fluidization is hoped for, although actual experience with such small tube diameters is very limited.

High values for the Peclet numbers have been found, indicating plug flow. With magnetic mixer in action, the axial mixing increased, but the overall mixing state still was close to plug flow. For settled packed bed $\left(L_{0}=0.05-0.1 \mathrm{~m}\right)$ under these conditions:

$$
\operatorname{Re}_{p}=\frac{<u>\rho_{l} d_{p}}{(1-\varepsilon) \mu_{l}} \sim 1
$$




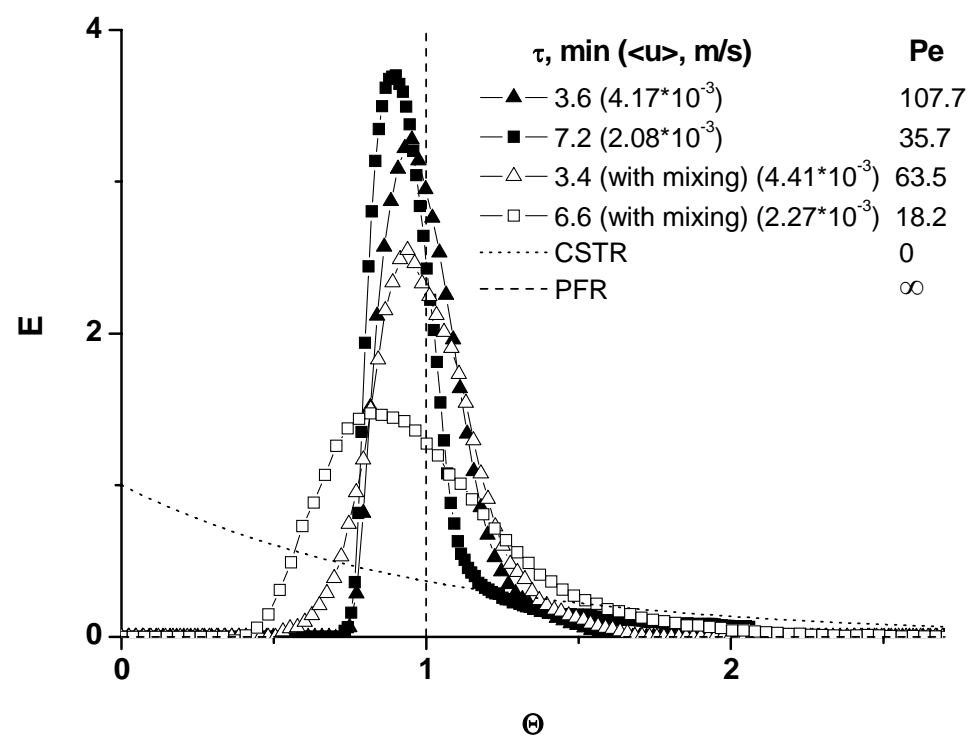

Figure 12. Reduced residence time distribution: $E(\theta)$ of the liquid tracer in the fluidized bed. $L_{0}=$ $0.05-0.1 \mathrm{~m} ; L=0.90 \mathrm{~m} ; d_{p}=100-150 \mu \mathrm{m} ; d_{i n}=0.00412 \mathrm{~m}$.

Schmidt number was:

$S c=\frac{\mu_{l}}{\rho_{l} \mathbf{D}} \sim 1000$

Literature results can be summarized as: $\frac{\langle u\rangle d_{p}}{D_{L}} \sim 0.5$ (see Westerterp et al. ${ }^{9}$ ) or:

$P \mathrm{e}=\frac{<u>d_{p}}{D_{L}} \cdot \frac{L}{d_{p}}=0.5 \frac{L_{0}}{d_{p}} \sim 200-400$

This would also clearly lead to plug flow.

\section{Axial Mixing of the Particles in the Fluidized Bed}

Particles used as a catalyst will behave uniformly if they are mixed sufficiently during the conversion tests, thus eliminating possible axial activity and coking profiles. 
To get an estimate of the particle mixing times, a separate test was carried out.

Glass particles of $d_{p}=100-150 \mu \mathrm{m}$ were used. A given amount of particles were colored with water insoluble ink and introduced at the top of the fluidized bed (see Figure 13). The light absorbance, found to be proportional to concentration of colored particles, was measured at a given position along the bed with a calibrated light source and a detector, as sketched in Figure 13.

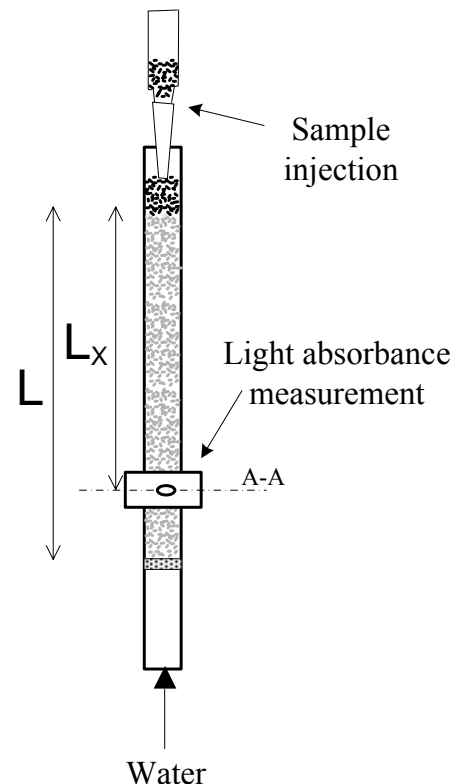

$\frac{\text { Cross section of measuring device: }}{\text { A-A }}$

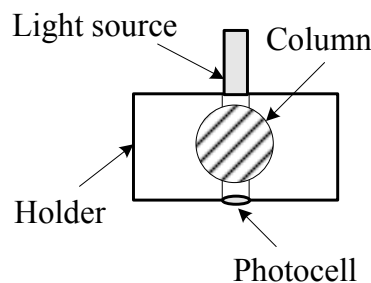

Figure 13. Scheme of axial mixing of solids test system.

A typical test result is given in Figure 14. 


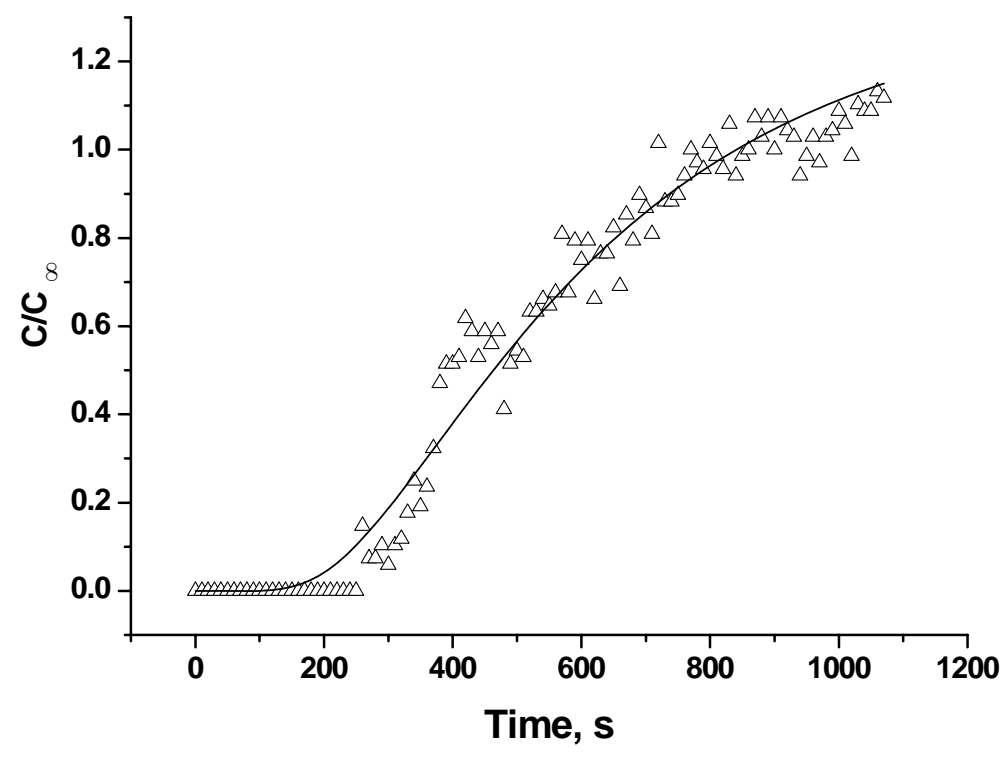

Figure 14. Measured concentrations and the fit curve of a solids mixing test. $d_{i n}=4 \mathrm{~mm} ; L=0.103$ $\mathrm{m} ; L_{x}=0.038 \mathrm{~m} ; d p=100-150 \mu \mathrm{m}$.

Mixing coefficients have been calculated from May ${ }^{12}$ :

$\frac{C}{C_{\infty}}=1+2 \sum_{i=1}^{\infty} e^{-(i \pi)^{2} \cdot \frac{E_{p} t}{L^{2}}} \cdot \cos \left(\frac{i \pi L_{x}}{L}\right)$

and are plotted in Figure 15 together with the prediction from the mixing correlation for particles in liquid fluid beds (Dorgelo et al. ${ }^{13}$ ).

$\frac{E_{p}}{m^{2} s^{-1}}=0.1\left[\frac{<u>}{m s^{-1}}\right]^{2}$

valid for:

$10^{-3}<\frac{<u>}{m s^{-1}}<1$ 


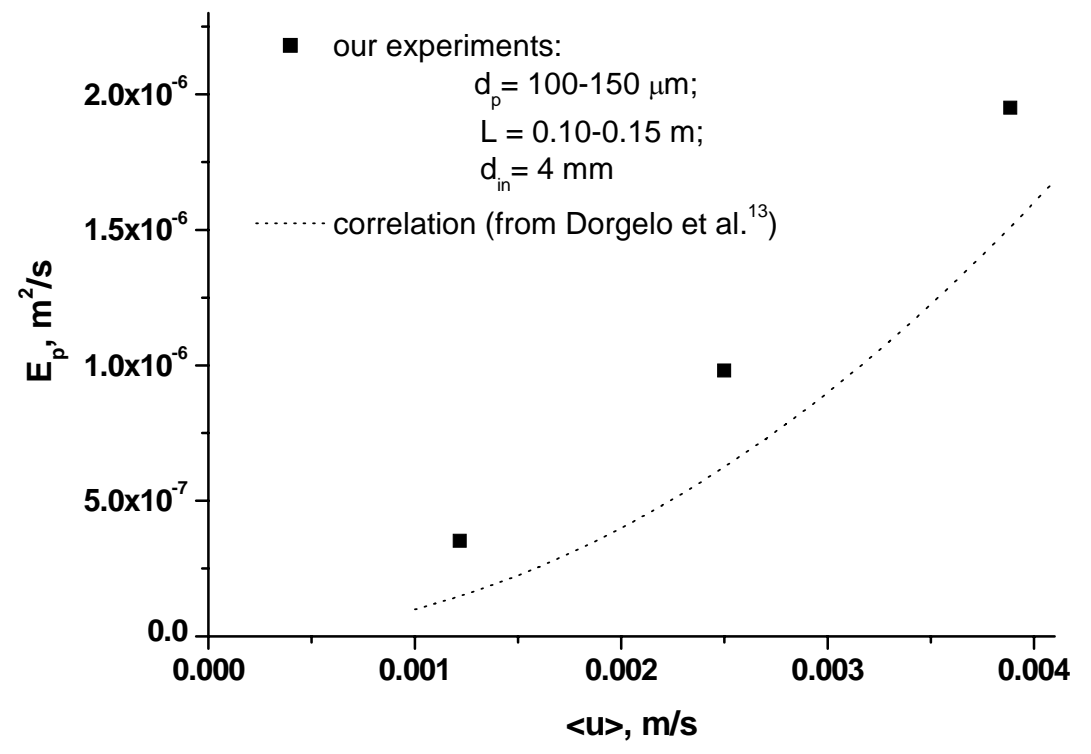

Figure 15. Axial mixing coefficient of particles in the liquid fluidized bed.

Despite the extremely small bed dimensions, the general trends of the present data follow the same trend as found by other investigations, although the present data seem somewhat higher. This is expected as axial dispersion is very sensitive to deviation from vertical position (malalignment). This effect was illustrated in the work of Dorgelo et al., ${ }^{13}$ who studied the time of travel of particles in the fluidized bed. Their results showed that already an inclination of just 0.5 resulted in a decrease of the time of travel of ca. $30 \%{ }^{13}$ Anyhow, the mixing coefficients of the particles are not high enough to ensure complete mixing on the time scale of the fluid residence time or test run time. For $\tau=600 \mathrm{~s}$ in a reactor of $0.9 \mathrm{~m}$ :

$F O=\frac{E_{p} \tau}{L^{2}} \sim \frac{5 \cdot 10^{-7} \cdot 600}{0.9^{2}}=3.7 \cdot 10^{-4}$

while for a reasonable degree of mixing in the particles: $F_{O} \approx 1$, which corresponds to a mixing time of $3.2 * 10^{6} \mathrm{~s}$, or $450 \mathrm{~h}$. Therefore, also in a fluid bed char deposition and catalytic activity profiles could develop, if no additional mixing mechanism is introduced. 


\section{Possibility of Bubble Formation}

As the solubility of gases in water is thermodynamically limited, the possibility that the gas produced in HTC forms bubbles inside the reactor, thus producing an additional phase, needs to be evaluated. Due to the lack of precise information on mixtures produced during $\mathrm{HTC}$ and the fact that $\mathrm{CO}_{2}$ is the main gas component produced, the water- $\mathrm{CO}_{2}$ system was considered (see Corvetto ${ }^{14}$ ). The analysis shows that bubbles would be formed at the $\mathrm{CO}_{2}$ production levels ca. 3 times higher than those measured in our non-catalytic experiments (see chapters 3 and 4). For example, if feedstock with $25 \mathrm{wt} \%$ of biomass is converted at $305^{\circ} \mathrm{C}$, bubbles would be formed if the $\mathrm{CO}_{2}$ yield reaches $24 \mathrm{wt} \%$ of the feedstock at 100 bar, and $36 \mathrm{wt} \%$ at 150 bar. In practice we measured $\mathrm{CO}_{2}$ yields higher than $16 \mathrm{wt} \%$ only in special cases (residence times of 1 day and 10 days, and catalytic tests, see chapter 3 ). Having this in mind, the possibility of the $\mathrm{CO}_{2}$ bubble formation during HTC without catalyst can be ruled out and setting the pressure high enough to ensure liquid state of water is sufficient to avoid $\mathrm{CO}_{2}$ gas bubbles. However, as $\mathrm{CH}_{4}$ or other gasses which could be formed in larger quantities in catalytic experiments have lower solubility than $\mathrm{CO}_{2}$, this additional gas phase formation remains an important point of consideration for catalytic HTC processes.

\section{Operation at HTC Conditions}

A few scouting tests with table-top setup were carried out with biomass conversion.

Quartz $\left(d_{\text {in }}=0.002 \mathrm{~m} ; d_{\text {out }}=0.006 \mathrm{~m}, \mathrm{~L}=0.9 \mathrm{~m}\right)$ and stainless steel $\left(d_{\text {in }}=0.002\right.$ and $0.004 \mathrm{~m} ; d_{\text {out }}=0.004$ and $0.006 \mathrm{~m}, \mathrm{~L}=0.9 \mathrm{~m}$ ) reactors were used for these hot conversion tests. As mentioned above, working with quartz has advantages. However, the glass-metal connections turned out to be an extremely sensitive part of the setup. The O-ring, and twocomponent glue connections were only possible if the connections were kept outside the heated zone.

Hot conversion tests were performed using glucose and biomass (wood powder) - water slurry (5 wt \%) with carboxymethylcellulose (5 wt \%) as slurry stabilizer.

Snapshots of the quartz reactor content at the reaction temperature and at different residence times are given in Figure 16. In these photos black particles of char can be seen, that stick to the wall of the reactor. During the experiment, the particles could be seen moving in stick-slip flow. The quantity of these particles increased with decreasing flow rate and with the temperature at the observation position (see Figure 6 for temperature 
profiles). Note that no char can be observed at 1 min residence time, but that at the snapshot position at this flow rate, the temperature is still much lower than required for HTC.

Probably a glass bead fluid bed could counteract the deposits on the reactor wall by the scouring action of the particles. This has been demonstrated for membrane fouling and heat exchangers (see, e.g. Van de Velden et al. ${ }^{15}$ )

The products of the test runs at HTC conditions could not be analysed because of interruptions due to blockages that manifested in the backflow prevention valve (see Figure 1). This valve was considered necessary to prevent the sudden outflow of the sample collection vessels. These vessels had a volume under pressure of about $300 \mathrm{ml}$. This volume can be reduced in future designs if a pressure controller connected to a gas sampling bag is installed in the gas phase of the sample collection vessels. In this way the backflow valve can be eliminated, the pressure kept constant during the run and all the outflowing products collected, without the use of a reduction valve in a three phase (liquid/gas/solid) line.

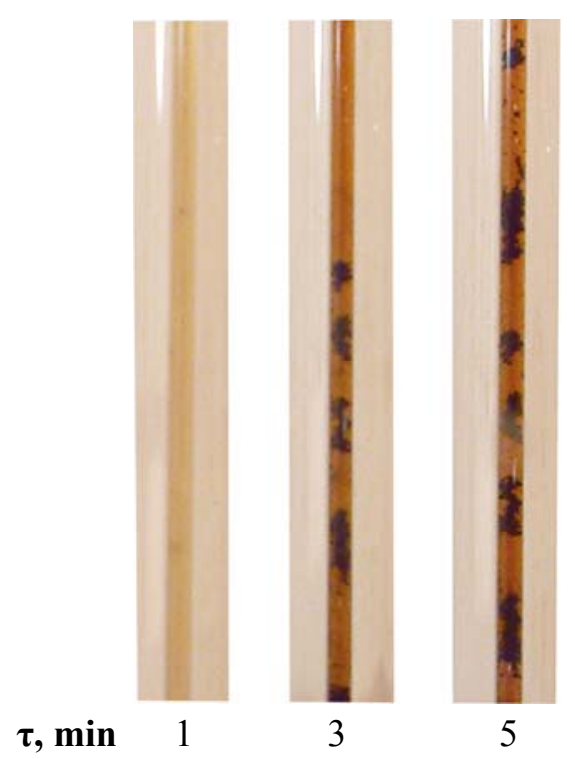

Figure 16. Snapshots during HTC of glucose solutions in a continuous setup at different residence times. $C_{0}=5 \mathrm{wt} \% ; \tau=1,3$ and $5 \mathrm{~min}, L$ (covered with heating tape) $=0.15 \mathrm{~m}, T_{\infty}^{\text {heating tape }}=330^{\circ} \mathrm{C}$; $T_{\infty}^{\text {oven }}=300{ }^{\circ} \mathrm{C}$. Snapshot location: $L_{x}=$ ca. $0.4 \mathrm{~m}$ (from the reactor inlet) (see Figure 5 for temperature at the location of the snapshot).

Meanwhile, successful HTC tests using pyrolysis oil as the feedstock have been conducted within our TCCB research group in a similar bench scale continuous setup, but incorporating a reducing valve. ${ }^{15}$ This was possible due to the lower amount of char being 
produced due to low residence times. To get similar success with glucose and biomass/water slurries for longer residence times and for tests with catalysts in continuous operation, further development on the bench scale plant is necessary.

\section{Conclusions}

\section{Downsizing to Bench Scale}

Downsizing a continuous HTC setup to bench scale size for research purposes is justified by possibility of a more flexible, cheaper, effective and safe experimentation. In downsizing several hurdles have to be overcome like, feeding of biomass/water slurries, blockage due to cake formation and pressure control. Moreover, control of the residence time distribution, the application of a liquid/solid fluidized bed elimination of a pressure reducing valve and quartz material reactor for visualization and inspection, are desired features.

Several sub-systems of such a plant have been tested.

\section{Feedstock Pumping}

Two devices were designed and tested: a piston autoclave and a lifted fluid bed. Piston autoclave could be operated only after addition of carboxymethylcellulose. This is a disadvantage because of interference with the conversion tests. A specially designed lifted fluid bed feeder was able to pump a slurry of wood particles in water, although mass ratio of wood to water in the slurry was restricted to value $<0.1$.

\section{Tubular Reactor and Macro Mixing}

In a quartz tubular reactor $\left(d_{\text {in }}=4 \mathrm{~mm} ; \mathrm{L}=0.9 \mathrm{~m}\right)$ at laminary flow, axial mixing was demonstrated to be sufficiently low to be considered plug flow. A special device to increase the axial mixing indeed promoted axial mixing, but could not reach the extreme of a single mixer. Roughly two mixers in series could be reached for a column length of $0.9 \mathrm{~m}$. Higher extent of macro mixing requires shorter column and lower flow rates.

\section{Fluid Bed Operation}

In a tubular quartz reactor $\left(d_{\text {in }}=4 \mathrm{~mm}, \mathrm{~L}=0.9 \mathrm{~m}\right)$ a fluid bed of glass beads $\left(d_{p}=100-\right.$ $150 \mu \mathrm{m})$ was created. Despite the small dimensions regular fluid bed operation was 
observed. Residence time distribution was measured and showed plug flow. Attempts to increase the axial mixing had only very limited success.

A fluid bed in the bench scale setup allows heterogeneous catalysis with fewer chances for blockages compared to a packed bed. It could also be used for counteracting reactor wall deposits of char.

\section{Operation Under HTC Conditions}

The bench scale HTC plant could be operated with pyrolysis oil. This has been applied in a consecutive project within our TCCB research group.

With charring and coking feedstocks like glucose solutions (glucose concentration $>1 \mathrm{wt}$ $\%$ ), under typical HTC residence times, blocking took place and char deposits on the reactor wall could be observed. However, deposits could be moved by the fluid flow itself and possibly by scouring action of a glass bead fluid bed.

\section{Possibility of Product Gas Bubble Formation}

The possibility of the formation of bubbles of produced gas is excluded for non-catalytic HTC, but is a point of attention in catalytic test when gas yield is considerably higher.

\section{Future Developments}

Several features from the wish list have still to be demonstrated in actual operation in future experiments at HTC conditions. 


\section{Notation}

C

$C_{0}$

$C_{\infty}$

$c_{p, l}$

$\bar{d}$

$d_{\text {in }}$

$d_{p}$

D

$D_{L}$

$\mathrm{E}(\mathrm{t})$

$\mathrm{E}(\theta)$

$\mathrm{E}_{\mathrm{p}}$

k

L

$L^{0}$

$L_{x}$

$\dot{m}_{\text {liquid }}$

$\dot{m}_{\text {solid }}$

n

$\mathrm{p}$

P

$\dot{Q}$

$t$

$\bar{t}$

$t_{\text {injection }}$

$\mathrm{T}$

$\overline{\mathrm{T}}$

concentration ( $\mathrm{mol} / \mathrm{m}^{3}$; for biomass: wt $\%$ )

initial concentration $\left(\mathrm{mol} / \mathrm{m}^{3}\right)$

equilibrium concentration $\left(\mathrm{mol} / \mathrm{m}^{3}\right)$

specific heat capacity of liquid $(\mathrm{J} / \mathrm{kg})$

average diameter (m)

inner diameter of a tube (reactor) (m)

particle diameter $(\mu \mathrm{m})$

coefficient of molecular diffusion $\left(\mathrm{m}^{2} / \mathrm{s}\right)$

coefficient of axial dispersion $\left(\mathrm{m}^{2} / \mathrm{s}\right)$

residence time distribution function or frequency function $\left(\mathrm{s}^{-1}\right)$

residence time distribution function for dimensionless time

axial mixing coefficient of particles in liquid fluidized bed $\left(\mathrm{m}^{2} / \mathrm{s}\right)$

first order reaction rate constant $\left(\mathrm{s}^{-1}\right)$

length of a reactor/ vessel; or a fluidized bed (m)

length of a packed bed (m)

length at which measuring (observation) takes place (m)

mass flow of liquid $(\mathrm{kg} / \mathrm{s})$

mass flow of solids $(\mathrm{kg} / \mathrm{s})$

exponent of the Richardson-Zaki equation

pressure (bar)

power (W)

heat flow $(\mathrm{J} / \mathrm{s})$

time (s, min)

first moment of $E(t)(s)$

sample injection time (s)

temperature $\left({ }^{\circ} \mathrm{C}\right)$

average temperature $\left({ }^{\circ} \mathrm{C}\right)$ 


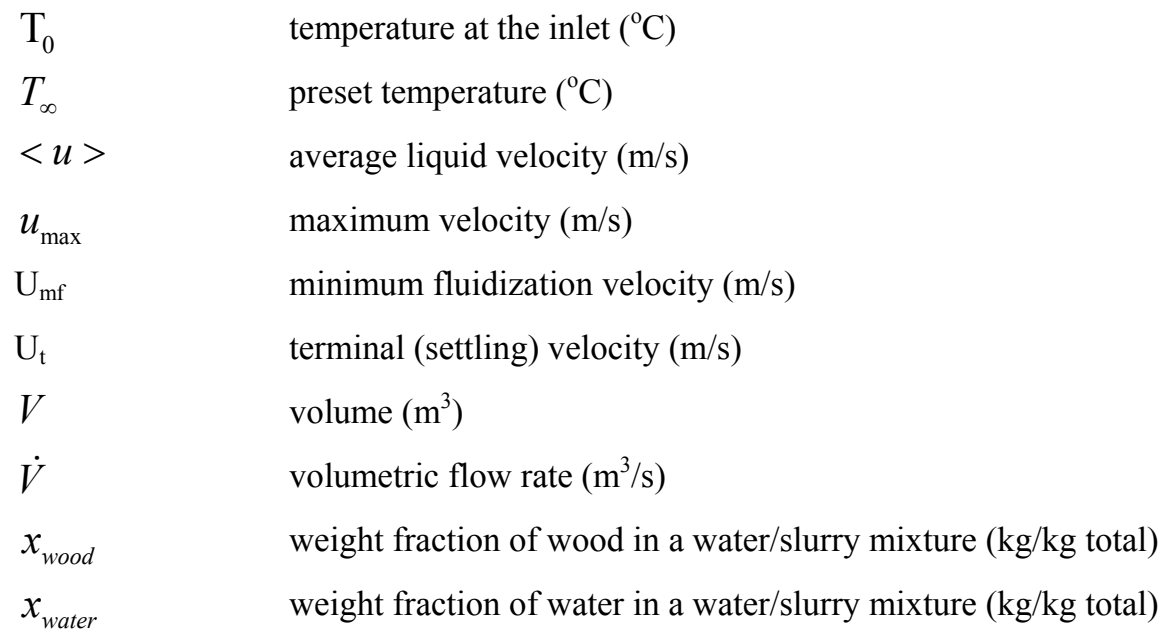

\title{
Superscripts
}

\author{
reactor reactor vessel \\ feeder feeding vessel \\ oven heating oven \\ heating tape heating element in the form of a flexible belt
}

\section{Greek letters}

$\begin{array}{ll}\alpha_{I D} & \text { internal heat transfer coefficient }\left(\mathrm{W} / \mathrm{m}^{2} /{ }^{\circ} \mathrm{C}\right) \\ \alpha_{O D} & \text { external heat transfer coefficient }\left(\mathrm{W} / \mathrm{m}^{2} /{ }^{\circ} \mathrm{C}\right) \\ \delta & \text { wall thickness }(\mathrm{m}) \\ \varepsilon & \text { fractional volume of fluid phase in a fluidized bed excluding internal } \\ & \text { particle porosity } \\ \varepsilon_{t}^{0} & \text { total porosity of an unexpanded fluidized bed } \\ \varepsilon_{t} & \text { total porosity of a fluidized bed } \\ \varepsilon_{p} & \text { particle porosity } \\ \varepsilon_{p b} & \text { fractional volume of fluid phase in a packed bed excluding internal }\end{array}$


particle porosity

dimensionless time $(t / \bar{t})$

$\lambda$

thermal conductivity $\left(\mathrm{W} / \mathrm{m} /{ }^{\circ} \mathrm{C}\right)$

$\mu_{l}$

dynamic viscosity of the liquid $\left(\mathrm{Pa}^{*} \mathrm{~s}\right)$

$\rho_{l}$

density of water $\left(\mathrm{kg} / \mathrm{m}^{3}\right)$

$\rho_{s k}$

sceletal density of wood $\left(\mathrm{kg} / \mathrm{m}^{3}\right)$

$\rho_{s}$

density of solids $\left(\mathrm{kg} / \mathrm{m}^{3}\right)$

$\tau$

residence time (s, min)

$\tau_{F}$

Fourier time $\left(d_{i n}^{2} / \mathbf{D}\right)(\mathrm{s})$

$\sigma_{t}$

$\sigma_{\theta}$

standard deviation of the residence time $\left(\mathrm{s}^{-1}\right)$

standard deviation of the dimensionless residence time $\left(\mathrm{s}^{-1}\right)$

$\Phi_{\text {liquid }}$

total volumetric flow rate of liquid $\left(\mathrm{m}^{3} / \mathrm{s}, \mathrm{ml} / \mathrm{min}\right)$

$\Phi_{\text {fluidisation }}$

volumetric flow rate of liquid for fluidization $\left(\mathrm{m}^{3} / \mathrm{s}, \mathrm{ml} / \mathrm{min}\right)$

$\Phi_{\text {slurry }}$

volumetric flow rate of fluid/solid mixture resulting from lifting the

fluidized bed $\left(\mathrm{m}^{3} / \mathrm{s}, \mathrm{ml} / \mathrm{min}\right)$

\section{Dimensionless groups}

Ar

Archimedes number $\left(\frac{g d_{p}^{3} \rho_{l}\left(\rho_{s}-\rho_{l}\right)}{\mu_{l}^{2}}\right)$

Fo

Fourier number $\left(\frac{E_{p} \tau}{L^{2}}\right)$

$\mathrm{Pe}$

Peclet number $\left(\frac{<u>L}{D_{L}}\right)$

$\operatorname{Re}$

Reynolds number $\left(\frac{<u>\rho_{l} d_{i n}}{\mu_{l}}\right)$

$\operatorname{Re}_{\mathrm{p}}$

Reynolds number for the particle $\left(\frac{<u>\rho_{l} d_{p}}{(1-\varepsilon) \mu_{l}}\right)$

Sc

Schmidt number $\left(\frac{\mu}{D \rho_{l}}\right)$ 


\section{References}

${ }^{1}$ Thigpen, P. L. ; Berry, W. L. Operation of the biomass facility at Albany, OR, Proc. 3rd Annual Biomass Energy Systems Conf., 5-7 June, Golden, Colorado, SERI/TP-33-285, 1979, pp.521.

${ }^{2}$ Goudriaan, F.; Van de Beld, B.; Boerefijn, F. R.; Bos, G. M.; Naber, J. E.; Van der Wal, S.; Zeevalkink, J. A. Thermal efficiency of the HTU Process for biomass liquefaction. In Proceedings of the conference: Progress in Themochemical Biomass Conversion (edited by Bridgwater, A. V.), Blackwell Science: England, 2000; pp 1312.

${ }^{3}$ Fang, Z.; Minowa, T.; Smith, Jr., R. L.; Ogi, T. Kozinski, J. A. Liquefaction and Gasification of Cellulose with $\mathrm{Na}_{2} \mathrm{CO}_{3}$ and $\mathrm{Ni}$ in Subcritical Water at $350{ }^{\circ} \mathrm{C}$. Ind. Eng. Chem. Res. 2004, 43, 2454.

${ }^{4}$ Watanabe, M.; Aizawa, Y.; Iida, T.; Levy, C.; Aida, T.M; Inomata, H.; Glucose reactions within the heating period and the effect of heating rate on the reactions in hot compressed water. Carbohydrate Research 2005, 340, 1931.

${ }^{5}$ Potic, B. Gasification Of Biomass In Supercritical Water, PhD thesis, University of Twente, 2006.

${ }^{6}$ Knežević, D; Schmiedl, D.; Meier, D.; Kersten, S.; Van Swaaij, W. High-Throughput Screening Technique for Conversion in Hot Compressed Water: Quantification and Characterization of Liquid and Solid Products. Ind. Eng. Chem. Res. 2007, 46, 1810.

${ }^{7}$ Seider, E.N., Tate, G.E., 1936. Heat transfer and pressure drop of liquids in tubes. Ind. Eng. Chem. 1936, 28, 1429.

${ }^{8}$ De Miguel Mercader, F. - to be published

${ }^{9}$ Westerterp, K.R.; Van Swaaij, W.P.M.; Beenackers, A.A.C.M. Chemical Reactor Design and Operation, ISBN: 978-047191730-4, Wiley; 2 edition, 1988

${ }^{10}$ Aris, R. Dispersion of Soluble Matter in Solvent Flowing through a Tube. Proc. R. Soc. Lond. A 1956235,67

${ }^{11}$ Khan, A.R.; Richardson, J.F. Fluid-particle interactions and flow characteristics of fluidized and settling suspensions of spherical particles. Chem. Eng. Comm. 1989, 77, 111.

${ }^{12}$ May, W. G. Fluidized bed reactors studies. Chem. Eng. Prog. 1959, 55, 49.

${ }^{13}$ Dorgelo, E. A. H.; Van der Meer, A.; Wesselingh, J.A. Measurement of the axial dispersion of particles in a liquid fluidized bed applying a random walk method. Chem.Eng.Sci, 1985 40, 2105

${ }^{14}$ Crovetto, R. Evaluation of Solubility Data of the System $\mathrm{CO}_{2}-\mathrm{H}_{2} \mathrm{O}$ from $273 \mathrm{~K}$ to the Critical Point of Water. Journal of Physical and Chemical Reference Data 1991, 20, 575.

${ }^{15}$ Van der Velden, P.M.; Van der Waal, M.J.; Van Swaaij, W.P.M. Improvement of membrane processes by fluidized particles. In proceedings: Symposium Transfer Processes in Particle Systems, Nürnberg, 1977, 77, Vol. 2, M 42. 


\section{CHAPTER 6}

Conclusions, Outlook and Recommendations 
In the present work a quartz capillary technique was developed, which allows fast, safe, cheap and efficient experimentation. The technique has been used to study hydrothermal conversion (HTC) of biomass. Series of complete elemental and mass balances were obtained with three feedstocks: glucose, wood and pyrolysis oil. The influences of temperature, residence time and concentration were studied without the burden and blurring effects of lengthy heating and cooling times, often observed in practice in large batch autoclaves. The obtained data cover a wide range of operation conditions significantly extending the limited sets of complete data available in literature. Moreover, because quartz is an inert material, the developed method is very suitable for catalyst screening, while avoiding the possible catalytic influence of the reactor wall.

Char, water and gas formation have been studied in detail with respect to residence time, concentration, temperature and type of feedstock, while also determining the yield and composition of the oil product. Two different mechanisms of char formation have clearly been identified. Part of the solid biomass remains in the solid state under the HTC conditions and is named primary char. It was shown that under a certain combination of HTC conditions (and/or catalysis) very low primary char yields (0 - 5 wt \%) are possible (see Chapter 4). On top of the primary char formation, a significant amount of char is produced in polymerization/polycondensation reactions. This product was named secondary char and is produced in important amounts when using high concentrations of feedstock at prolonged residence times.

It is generally recognized that during HTC of biomass, oxygen is separated from the organic product in the form of carbon dioxide and water. This deoxygenation is a major feature of HTC of biomass and is desired because it reduces the polarity of molecules, which simplifies their separation from the water phase. The accompanying benefit of deoxygenation is the increase in heating value. However, it was found that for a high degree of decarboxylation relative to dehydration a long residence time is required and this decreases the oil yield.

Our results show that low oxygen content of the oil can only partially be achieved in a favorable manner, as the desired decarboxylation is always accompanied by undesired dehydration. Dehydration occurs in the early stages of the process and is less desired as it implies hydrogen rejection from the oil, which makes its upgrading to transportation fuels more complicated and expensive because more hydrogenation will have to be applied.

Using glucose as model component for the sugar fraction produced during HTC a kinetic reaction path model with lumped products and intermediates was established, which describes the observed rates and yield trends correctly. The model was qualitatively supported by conversion tests and HTC conditions of known intermediates of glucose decomposition. This engineering kinetics model was extended to HTC of wood/water mixtures and to HTC of pyrolysis oil. Results for these feedstocks could be well explained 
by taking into account (partial) dissolution of wood, and the reactions that already occurred in the pyrolysis process in which pyrolysis oil is produced.

For the study of catalytic effects, the capillary technique is suitable because of the high throughput and because background catalytic activity from materials in the reactor walls can be ruled out. Several potential catalytic materials, including inorganic salts and some heterogeneous catalysts are screened for improved decarboxylation. Although with respect to the non-catalytic experiments an increase in the $\mathrm{CO}_{2}$ yield was observed (up to $30 \%$ more gas), this improvement was very limited relative to the feedstock ( $2-3 \mathrm{wt} \%$ more gas), highlighting the need for improved catalysts. Moreover, it was observed that catalysts could contribute to a reduction of char by its decomposition. In practical applications (fluidized) catalysts (but also inert solid particles) could effectively be used for managing char location and keeping the reactor clean.

Although batch experimentation offers important insights into the HTC process, transition to continuous operation cannot be made using these tests only. Therefore a bench scale continuous reactor setup with a small diameter reactor has been proposed, which would allow flexible, safe, cheap and fast experimentation (several experiments per day). Important steps of a continuous HTC installation were demonstrated: feeding of biomass slurries, for which two concepts were proposed and tested: a lifting fluidized bed and a piston autoclave. The state of macro mixing realized in these small diameter reactors was studied in a magnetically mixed tubular reactor. Moreover, a very small diameter fluid bed reactor was realized, and mixing of fluid and particles established. Also, heat transfer and the possibility of gas formation at the reaction conditions were considered.

These developments were successfully used and further developed in subsequent research in the TCCB group for experimentation in such a continuous setup with low charring feedstocks (low concentration glucose solutions and pyrolysis oil). For strongly charring feedstocks, like high concentration glucose solutions, continuous operation still needs further development.

\section{Processing options}

As stated in the introduction, the HTC products can have different application. Gaseous fuels (mainly methane) can be produced via catalytic HTC, but for complete conversion of the biomass to methane rich gas, long residence times are still required ( $>1 \mathrm{~h}$ ). This seems not very attractive in view of the high pressure required ( \pm 150 bar) leading to large, thickwalled vessels and relatively high capital investments. At supercritical conditions (mixtures of hydrogen and) methane can be produced at much shorter residence times, although at still higher temperatures and pressures. 
With HTC, hydrophobic solid and liquid fuels for combustion and gasification can be made from biomass/water mixtures or slurries. Although not yet applied on a large scale, several firms are offering such processes, based on relatively recent development. Formation of a solid/liquid hydrophobic phase to be used for its heating value does not require a high yield of a low molecular weight, upgradable fraction. In this case, the requirements for hydrophobic product, consisting of primary and secondary char and oil are: reasonable transport and storage properties and a sufficiently high heating value. Factors that increase the formation of secondary char such as, high feedstock concentrations, long residence times and unfavorable temperature profiles, are not of primary concern here. Instead, process optimization should focus on separating organics from an aqueous feedstock and decreasing the oxygen content of a combined oil + char product. Economics will strongly depend on feedstock cost and selling price of the products. Because it is still a rather complex high pressure (200 bar) conversion process, which produces a product used only for its combustion value, such HTC process can only be economically feasible if applied to feedstocks with a very low, or preferably negative value (waste). Therefore this HTC processing option should focus on handling aqueous biomass / waste streams. Robust high pressure feeding pumps, required residence times, and especially wastewater postprocessing are still technical challenges. In conclusion, more demonstration and commercial applications are needed for a definite conclusion on this type of process.

HTC aimed at producing useful intermediates for making transportation fuel blends is still in an early stage of development. Apart from the $\mathrm{HTU}^{\circledR}$ process, at present only little developments take place. However, this option could be economically attractive if a product with high(er) added value is made (e.g. a transportation fuel precursor). The high value product, if produced in a significant yield, would even justify the use of dry solid biomass as feedstock, despite the complexity of feeding slurries of dry biomass and addition and recycling of water. In order to make the process attractive, oxygen should be removed from the biomass feedstock during the process by $\mathrm{CO}_{2}$ formation (instead of by water formation), and the production of very heavy components (in char and in oil) should be avoided as much as possible.

In the present thesis it has been shown that for primary products from sugar polymers like, cellulose and hemicellulose (together $\pm 60 \%$ of lignocellulosic biomass), a large part of oxygen is removed as water in the first few minutes via rapid dehydration. Carbon dioxide is formed over the whole reaction time continuously, but at a relatively low rate after 10 minutes. This leads to conflicting demands of short residence times to avoid char, but then water formation is the main route of oxygen removal; or long residence times to profit from $\mathrm{CO}_{2}$ removal, but then char formation will be excessive.

Both options are disadvantageous for commercial operation. The interference of catalysis could possibly change the situation. 
Moreover, for minimizing of secondary char requires rapid heating and cooling have to be realized, although this is hard to achieve in conventional heat exchanger networks of a large scale continuous plant. The possible solutions could be in direct steam injection, application of a solid heat carrier and integration with processes such as wet oxidation to generate process heat.

The processing route towards transportation fuel precursors needs significant developments in terms of improving heat transfer rates, under possibly fouling conditions, liquid solids/slurry handling, optimizing desired product yields and separation procedures, and realizing efficient decrease of the oxygen content for different feedstocks.

\section{Recommendation for future studies}

The developed reaction model gives a necessary starting point for a more sound process development. However, this model needs to be optimized and verified for other feedstocks. Development of different HTC processes is hampered by the high costs of experimentation. The high throughput quartz capillaries technique used in this thesis has proven to be very helpful in this respect. However, also the bench scale continuous operation should be further developed. New leads to realize this are presented in this thesis. Such a setup should be used to study process and equipment features such as: improved feeding and heating up, influence of the state of mixing at the reaction conditions, minimization and handling of solid products formed, material selection for HTC plants, to name a few. The concept of char handling and reactor cleaning during HTC of biomass, using an inert or catalytic solid carrier should be further studied.

Finally, the development of improved and robust catalysts, which could increase the oil yield and decrease the oil's molecular weight, is highly desired. Such a catalyst should be resistant to fouling deactivation and attrition and/or re-generable under mild conditions. 


\section{Acknowledgements}

The journey towards the completion of this thesis was anything but a simple one. This involved a lot of learning things the hard way, disappointments, conflicts and growing up, but also hope and friendships, excitement and travels. In this time I have learned a lot and it has been a sort of a life school, which I would not been able to go through alone.

The fact that I get to write this part of the thesis is to the greatest extent thanks to my supervisors Sascha Kersten and Wim van Swaaij. They have both shown great patience, attention and often more than just a friendly advice and help. Although they both deserve special mention in this note, I wish to specially thank Sascha Kersten for the scientific and moral input during these years. Thanks also go to his partner, Diana and their children for understanding for hours that my work has consumed in their lives.

I would like to thank my paranimphs for their help in organizing the final stage of this work and, in advance, for preventing me from being too nervous on the day of the defense. As I write this thank you note weeks before that, they still have to do it, but I am confident that they will succeed.

A special thanks goes to the students I worked with during my $\mathrm{PhD}$ work: Prasad, Elly and Antal for all their help and input in this research. Dietrich Meier and especially Detlef Schmiedl I thank for the scientific feedback and analytical work, especially in developing the capillary technique. I would like to thank Wies and Yvonne for the help with Dutch letters, especially in the early days of my life in the Netherlands and for friendliness and patience with me when I started to talk Dutch. I would like to thank the technicians of the High-pressure lab, Johan, Benno and Karst, but also Fred, Geert and Robert, for their technical assistance and practical ideas and all the glass technicians of the University for their assistance. I am also grateful to all my colleagues in Royal Haskoning for useful advices and support. Also I would like to thank Vlada and my brother Ivan from $\mathrm{Ti}$ Computers for work on the cover of this book.

I would like to thank all the friends who have marked the past 7 years of my life. My old friends, for our long friendship that survived the distance, and even got stronger, giving me the necessary balance in life: Biljana, Aca, Sale, Vladan, Xiaoquan, Tanja. Monija, Tijana Ivan, Aleks, Dragana, Vlada \& Miljana. I would like to thank Darja, for her patience and kindness while we were a couple and her friendship afterwards. Special thanks to Wieneke for helping me learn Dutch, while also teaching me a lot about life, but also to Femke as they both made the writing process easier for me. I would also like to mention all the people I have met in the Netherlands with whom I shared unforgettable moments: Pavlina, Dimitris, Dragan, Tanja, Ferran, Michael, Rachel, Wulf, Mariken, Sander, Blanca, Arta, Guus, Ljuba, Dimitrios, Tom, Monique and Nataša,. "Gnjurci”: Blaža, Raša, Bojan, Zoki, Boris, Žika, Marko, Vojkan, Ljuba, Nataša, Tanja, Miloš, Marija and Anna. 
Želeo bih da se zahvalim svima u familiji jer su verovali u mene i činili me jačim iako često toga nisu ni bili svesni: Milićevićima, ujka Tomi, ujni Gordani, Lili i Saletu, Marku, Maji i Milanu, Užičanima, tetki Lepi i teči Milenku, Miri i Brankici i familiji iz Nemačke, strini Violeti, stricu Zoranu, Mariji, Huseu i svoj njihovoj dečici.

Ipak, posebno hvala mojim rodjenima, majki Dobrili i bratu Ivanu za veru u mene i bezrezervnu podršku. Naravno, hvala i našoj Desi koja pazi na njih dok ja nisam tamo. Laru stric jedva čeka da upozna!

I would also like to dedicate a few lines to the memory of my late father. The thought of him continues to bring in me the persistence and the will to do better, and move forward, not give up.

And last but not least, special thanks to Colleen, my partner and best friend, who helped me enormously on this journey. She continues to be the focus of my thoughts about the future.

\section{Dragan}

08.2009. 


\section{Curriculum Vitae}

Dragan Knežević was born on 29. October 1975 in Belgrade, Serbia. After attending the $1^{\text {st }}$ Belgrade gymnasium he studied chemical engineering at the Faculty of Technology and Metallurgy at the University of Belgrade. Following a practical in Bundesanstalt für Materialforschung und Materialprüfung (BAM) in Berlin, Germany. He completed his studies in June 2001 with a graduation project on the topic of "Phase transfer catalysis".

From April 2002. he has been performing research of biomass conversion at the University of Twente. This thesis is a product of this work.

From October 2007 he is employed as a consultant/expert in the group: Waste management and energy technology of Royal Haskoning, The Netherlands. 


\section{List of publications}

Knežević, D.; Rep, M.; Kersten, S.R.A.; Prins, W.; Van Swaaij, W.P.M. Hydrothermal liquefaction and pyrolysis: A visualization study, In: Science in Thermal and Chemical Biomass Conversion, Victoria, Canada, 2004, A. V. Bridgwater and D. G. B. Boocock editors, CPL Press, 2006, pp.1082-1090.

Knežević, D.; Schmiedl, D.; Meier, D.; Kersten, S.R.A.; Van Swaaij, W.P.M. High-

Throughput Screening Technique for Conversion in Hot Compressed Water: Quantification and Characterization of Liquid and Solid Products. Ind. Eng. Chem. Res. 2007, 46, 1810.

Knežević, D.; Van Swaaij, W. P. M.; Kersten, S. R. A. Hydrothermal conversion of biomass: Part I, glucose conversion in hot compressed water. Ind. Eng. Chem. Res. 2009, 48, 4731 .

Knežević, D.; Kersten, S.R.A.; Van Swaaij, W.P.M. Hydrothermal conversion of biomass: Part II, wood and pyrolysis oil conversion in hot compressed water. Submitted to: Ind. Eng. Chem. Res. 